Joachim Reitner, Yang Qun, Wang Yongdong and Mike Reich (Eds.)

Palaeobiology and Geobiology of Fossil Lagerstätten through Earth History

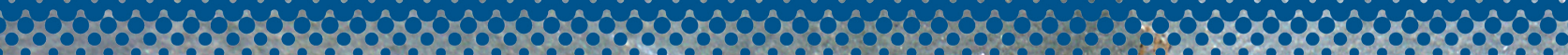
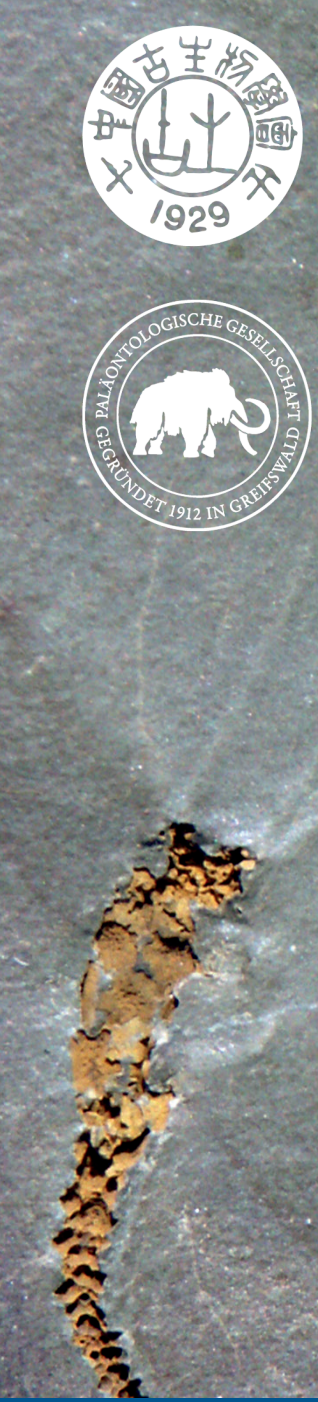

G民1 Universitätsdrucke Göttingen

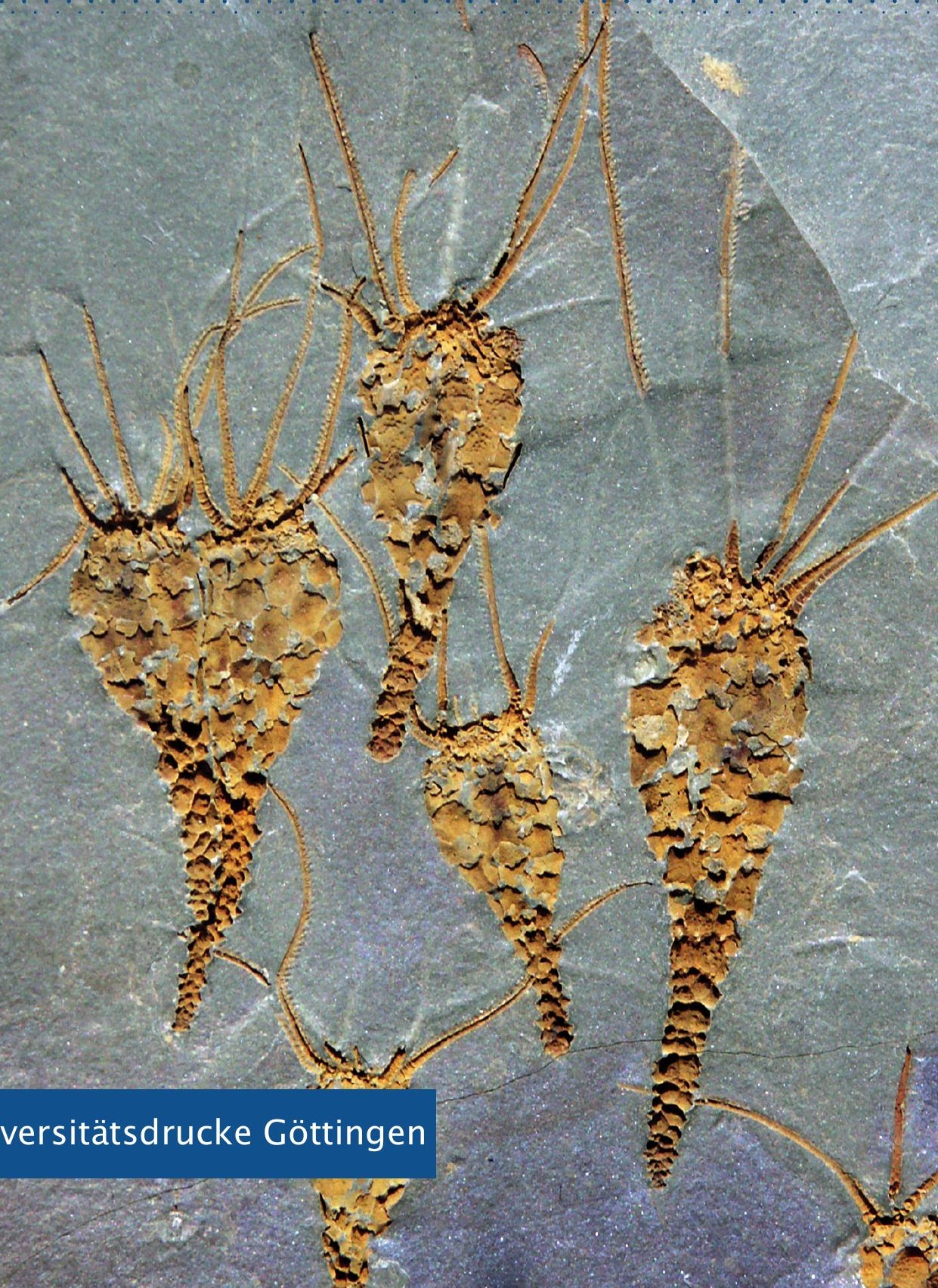



Joachim Reitner, Yang Qun,Wang Yongdong and Mike Reich (Eds.)

Fossil Lagerstätten

This work is licensed under the Creative Commons License 3.0 "by-sa", allowing you to download, distribute and print the document in a few copies for private or educational use, given that the creator is mentioned.

SOMERIGHIS RESERVED 
erschienen in der Reihe der Universitätsdrucke im Universitätsverlag Göttingen 2013 
Joachim Reitner, Yang Qun,

Wang Yongdong and Mike Reich

(Eds.)

With the collaboration of Luo Cui,

Vanessa J. Roden, Tanja R. Stegemann

Palaeobiology and Geobiology of Fossil Lagerstätten through Earth History

A Joint Conference of the

"Paläontologische Gesellschaft"

and the

"Palaeontological Society of China",

Göttingen, Germany,

September 23-27, 2013

Abstract Volume

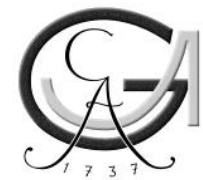

Universitätsverlag Göttingen 2013 


\section{Bibliographische Information der Deutschen Nationalbibliothek}

Die Deutsche Nationalbibliothek verzeichnet diese Publikation in der Deutschen Nationalbibliographie; detaillierte bibliographische Daten sind im Internet über $<$ http://dnb.ddb.de $>$ abrufbar.

In accordance with Chinese naming customs, personal names are listed in order of: last name, first name.

\section{Editorial contact}

Professor Dr Joachim Reitner

Dr Mike Reich

Geoscience Centre of the

Georg-August University of Göttingen

Goldschmidtstraße 1-5

37077 Göttingen, Germany

http://www.gzg.uni-goettingen.de

http://www.geobiologie.uni-goettingen.de

http://www.geomuseum.uni-goettingen.de

Professor Dr Yang Qun

Professor Dr Wang Yongdong

Chinese Academy of Sciences,

Nanjing Institute of Geology and Palaeontology

39 East Beijing Road

Nanjing 210008, P. R. of China

http://english.nigpas.cas.cn/

http://www.nigpas.cas.cn/

This work is protected by German Intellectual Property Right Law.

It is also available as an Open Access version through the publisher's homepage and the Online Catalogue of the State and University Library of Goettingen (http://www.sub.uni-goettingen.de). Users of the free online version are invited to read, download and distribute it.

Graphics and Layout: Mike Reich

Cover Design: Conny Hundertmark \& Mike Reich

Cover Photos: Jörg Ansorge, Gerhard Hundertmark, Georg Oleschinski, Mike Reich, Jes Rust 


\section{Contents}

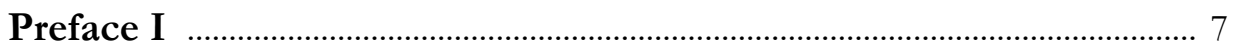

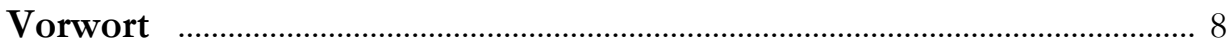

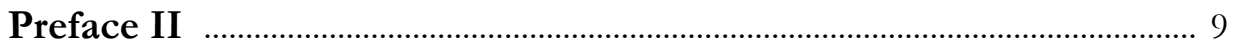

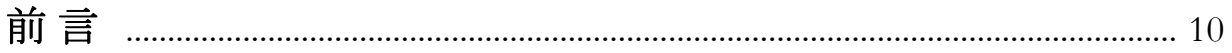

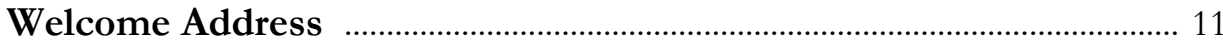

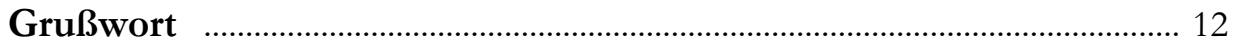

Abstracts of Oral \& Poster Presentations ………………………………... 13

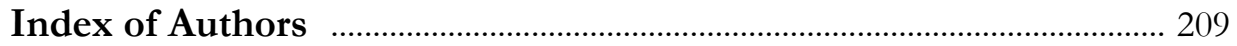


The printing of this volume was funded by:

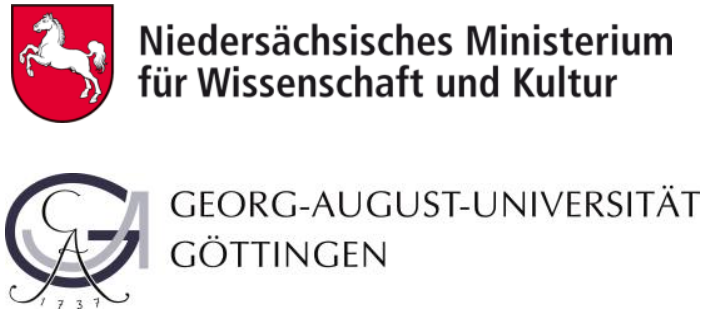




\section{Preface I}

Following the years 1926, 1937, 1977 and 2004, the annual meeting of the Paläontologische Gesellschaft will take place at the Georg-August University in Göttingen for the fifth time. This year, the meeting is hosted together with the slightly younger Palaeontological Society of China, our "sister society", founded in 1929. The joint international conference will take place on true historical grounds: Firstly, intensive palaeontological research has been conducted in Göttingen for over 260 years; secondly, the two founding members of the Palaeontological Society of China, Sun Yunzhu (1895-1979) and Yang Zhongjian (1897-1979), decided to found "their" Chinese palaeontological society on an excursion to the Harz mountains (1927, on the occasion of the annual meeting of the German geological society in Goslar), led by palaeontologists and geologists from Göttingen. The founder of our Paläontologische Gesellschaft - Otto Jaekel (1863-1929) - also had close ties with China. In addition to his interest in Chinese ethnology, cultural anthropology and history, Jaekel followed an invitation as professor of palaeontology at the Sun Yat-sen University (Guangzhou; formerly Canton) in the autumn of 1928. He only held this position for a short time, as he died of pneumonia (March $6^{\text {th }}$ ) shortly after participating in the sixth annual meeting of the Geological Society of China in Peking in February (13 $\left.{ }^{\text {th }}-14^{\text {th }}\right)$ of 1929 , where he was then buried in a German cemetery.

About 300 palaeontologists, biologists, geologists and other scientists from 16 countries, especially from Germany and the People's Republic of China, followed our invitation to a joint meeting in Göttingen. The conference theme Palaeobiology \& Geobiology of Fossil Lagerstätten through Earth History refers to the significance of Fossil Lagerstätten with exquisitely preserved organism remains, which enable us to gain insights into important details of the history of life on Earth as well as into the evolution of plants and animals. The term Fossillagerstätten is also closely tied to our university - Adolf Seilacher $(* 1925)$, professor for palaeontology at the Georgia Augusta between 1963 and 1965, first coined and specified this term in 1970.

This volume contains the abstracts for over 275 presentations (oral and poster) that have been contributed by more than 600 authors from 34 countries worldwide and will be presented at the joint meeting.

We wish all participants a pleasant and interesting conference, paired with a desire to strengthen and secure "our" science - today and in the future.

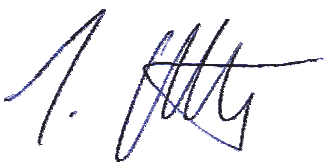

Joachim Reitner

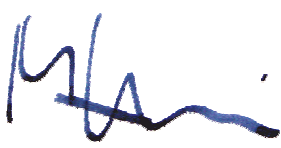

Mike Reich
Göttingen, September 2013 


\section{Vorwort}

Nach 1926, 1937, 1977 und 2004 findet nun zum fünften Mal die Jahrestagung der Paläontologischen Gesellschaft an der Georg-August-Universität Göttingen statt. In diesem Jahr erstmals gemeinsam mit unserer „Schwestergesellschaft“, der etwas jüngeren, 1929 gegründeten, Palaeontological Society of China. Die gemeinsame internationale Tagung findet durchaus auf historischem Boden statt: Zum einen wird in Göttingen seit mehr als 260 Jahren intensiv paläontologische Forschung betrieben; zum anderen fassten die beiden Gründungsmitglieder der Palaeontological Society of China, Sun Yunzhu (1895-1979) und Yang Zhongjian (1897-1979) auf einer von Göttinger Paläontologen und Geologen geführten Exkursion im Harz (1927, anläßlich der Jahrestagung der Deutschen Geologischen Gesellschaft in Goslar) den Entschluss, „ihre“ Chinesische Paläontologische Gesellschaft zu gründen. Auch der Gründer unserer Paläontologischen Gesellschaft - Otto Jaekel (18631929) - war eng mit China verbunden. Neben seinem Interesse für chinesische Ethnologie und Geschichte, folgte Jaekel auch im Herbst 1928 dem Ruf auf eine Professur für Paläontologie an der Sun Yat-sen Universität (Guangzhou; früher Kanton). Diese übte er jedoch nur kurz aus, da er Anfang März 1929, nach der Teilnahme an der 6. Jahresversammlung der Geological Society of China (13./14. Februar 1929) in Peking, an einer Lungenentzündung verstarb und dort auch auf dem deutschen Friedhof beerdigt wurde.

Annähernd 300 Paläontologen, Biologen, Geologen und andere Wissenschaftler aus 16 Ländern, vor allem aus Deutschland und der Volksrepublik China, sind dem Aufruf zu einer gemeinsamen Tagung nach Göttingen gefolgt. Das Tagungthema Palaeobiology \& Geobiology of Fossil Lagerstätten through Earth History verweist auf die Bedeutung von Fossillagerstätten mit vorzüglich erhaltenen Organismenresten, die detaillierte Einblicke in die Geschichte des Lebens auf unserer Erde, wie auch in die Evolution von Pflanzen und Tieren ermöglichen. Der Begriff Fossillagerstätten ist ebenso eng mit der hiesigen Universität verbunden - Adolf Seilacher (*1925), zwischen 1963 und 1965 Lehrstuhlinhaber und Professor für Paläontologie an der hiesigen Georgia Augusta, prägte und definierte diesen erstmals 1970. Der vorliegende Band enthält die Kurzfassungen zu mehr als 275 Präsentationen (Vorträge und Poster), die während der gemeinsamen Tagung von mehr als 600 Autoren aus 34 Ländern weltweit, vorgestellt werden.

Wir wünschen allen Teilnehmerinnen und Teilnehmern eine angenehme und interessante Tagung, verbunden mit dem Wunsch der Stärkung und Sicherung ,unserer“ Wissenschaft - heute und in der Zukunft.

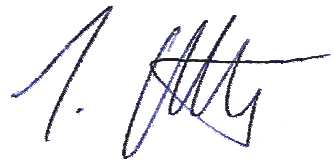

Joachim Reitner

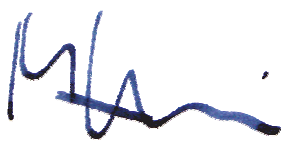

Mike Reich Göttingen im September 2013 


\section{Preface II}

As one of the earliest science associations established in China, the Palaeontological Society of China (PSC) has a history of over 84 years, though a younger society compared with our partner - the Paläontologische Gesellschaft of Germany. It is interesting to note that the idea of founding the palaeontological society in China was said to have been conceived by two German-trained Chinese palaeontologists, Sun Yunzhu (Y. C. Sun) (1895-1979) and Yang Zhongiian (C. C. Young) (1897-1979), when the two attended the annual meeting of the German Geological Society in Goslar and a field excursion to the Harz Mts. in 1927. In August of 1929, the Palaeontological Society of China was formally established in Beijing under the enthusiasm of the first generation of Chinese palaeontologists, when Ding Wenjiang (V. K. Ding), A. W. Grabau, and Sun Yunzhu were elected as the first officials of PSC.

Along with the development of over 84 year's of history, the PSC has become one of the most active members in the palaeontological circles in the world. It is noteworthy that during recent years, Chinese and German palaeontologists have dramatically increased their research cooperation and academic exchange with focuses on a diversity of topics in fossil and stratigraphic studies. In order to encourage and promote further collaboration in research and education with regard to the scientific and professional aspects of palaeontology, the Paläontologische Gesellschaft (PalGes) and the Palaeontological Society of China (PSC) formulated a memorandum of understanding on holding a joint scientific conference in Göttingen in 2013. This is the first time that PSC and PalGes hold a joint academic conference.

We are glad to report that nearly 100 Chinese palaeontologists will participate in the SinoGerman gathering (total of 300 people) to be held in the University of Göttingen, September 23-27, 2013. In a sense, we are tracing back the footsteps of Sun Yunzhu and Yang Zhongjian to Göttingen with new findings and perspectives to discuss with our fellow German palaeontologists. The conference theme Palaeobiology \& Geobiology of Fossil Lagerstätten through Earth History is most suitable to our time as recent discoveries of exquisitely preserved organism remains in China and elsewhere have enabled us to look into important details of the history of life on Earth as well as into the evolution of plants and animals.

We would like to express our sincere thanks, on behalf of all Chinese participants, to our partner organizers in Germany for their effort and enthusiasm to make this joint conference possible and successful. We believe that we mutually hope that this first SinoGerman Joint Palaeontological Society Meeting will provide a platform for further promoting academic exchange and cooperative research among German and Chinese scientists; it will also provide an opportunity for Chinese participants to examine fossil outcrops in Germany and neighboring European regions. We have no doubt that both Chinese and German (or otherwise) palaeontologists will benefit from the discussions via reports of new research results and via personal interactions.

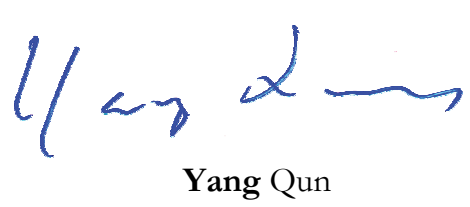

(President of the PSC)

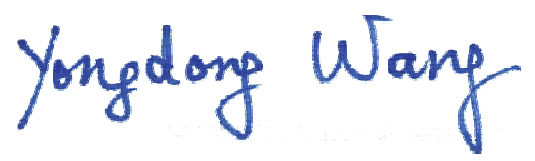

Wang Yongdong September 2013, Nanjing
(Secretary General of the PSC) 


\section{前言}

中国古生物学会是中国成立最早的自然科学学术团体之一, 至今已有84年的悠久 历史。中国古生物学会的创立与德国有着密切的联系和渊源。早在1927年, 当时留学 德国的中国古生物学者孙云铸 (1895-1979)、杨钟健 (1897-1979) 参加了德国地质学会 在 Goslar举行的年会, 并参加了由哥廷根大学地质古生物学者组织的Harz山脉地区 野外地质旅行考察, 他们在旅行途中酝酿在中国成立古生物学会。之后, 于1929年8 月, 由我国第一代古生物学家和著名地质学家丁文江、葛利普等在北京正式召开了中 国古生物学会成立大会, 并由孙云铸担任首任会长。

八十多年来, 中国古生物学会经历了初创、发展和壮大的不平凡历程, 成为国际 古生物学协会重要成员, 也是当今世界上会员最多、影响力最大、国际学术交流广泛 的古生物学术团体之一。尤其需要指出的是, 中国和德国的古生物学家在古生物学和 地层学领域的科研合作和学术交流方面，长期以来一直保留着密切的联系。为了进一 步加强中德两国古生物学的学术交流与合作, 中国古生物学会与德国古生物学会联合 决定于 2013年在德国哥廷根大学组织召开中德古生物学国际研讨会。这是中德两个具 有悠久历史的古生物学会首次联合组织的学术交流活动。

我们欣喜地看到, 有近百名来自中国的古生物学者参加将于2013年9月23-27日在 哥廷根大学举办的中德古生物学国际会议 (总参会人数近 300 名, 来自 16 个国家)。 从某种意义上说, 我们是在追寻中国老一辈古生物学者孙云铸和杨钟健的脚步, 来到 哥廷根, 与德国同行共同探讨古生物学的新发现、新进展并展望学科发展的未来。

本次国际会议主题为 “地球历史化石库的古生物学和地球生物学” , 正好反映了 中国及其它地区保存精美的古生物化石新发现, 并使得我们以此为基础探讨地球生命 的奥秘及其演化历史。我们认为, 中德两学会举办首次联合学术年会, 对于进一步促 进两国古生物学家的交流合作, 深入探索欧亚大陆生物演化历史, 共同探讨和开辟古 生物研究新的前沿, 具有重要意义。

本专辑包括了参加这次中德古生物学国际会议代表提交的 275 篇论文摘要（包括口 头报告或者展版报告）(作者来自 34 个国家）; 其中由中国学者提交的论文摘要近 80 篇 , 反映了中国古生物学者和德国以及国际同行近年来在古生物学各个领域所取得的新 进展。

在此, 我们代表全体参会的中国学者, 向德国古生物学会及其同行为成功举办此 次会议所付出的艰辛和努力表示衷心的谢意! 我们相信这次首届中国和德国古生物学 国际会议将为两国的古生物学家开展深入学术交流和合作研究提供新的平台。同时, 也为中国学者考察德国及邻近欧洲国家的化石产地和地层剖面提供了难得的机会。

我们相信, 中国和德国（以及其它国家）的古生物学者通过参加此次会议, 在研 讨和展示最新进展和研究兴趣方面, 将会获得圆满的学术收益和交流成果。

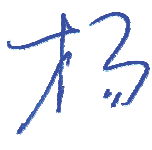

中国古生物学会理事长

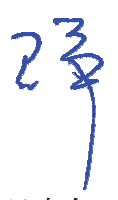

$$
\text { 长 }
$$

中国古生物学会秘书长
2013年9月，南京 


\section{Welcome Address}

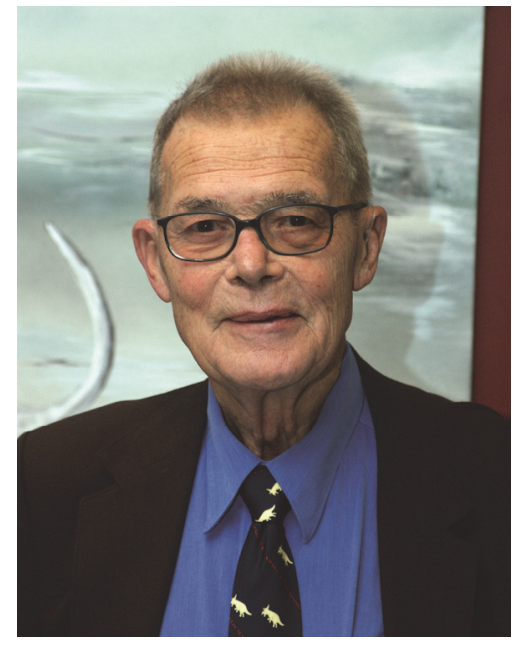

Adolf Seilacher, Göttingen, 2010
Since boldly agreeing to participate in the meeting of the Paläontologische Gesellschaft in Göttingen, unfortunately my condition has greatly deteriorated. Therefore I will not be able to come to Göttingen personally. I have been closely linked to the Paläontologische Gesellschaft for 74 years now. When I found out about the conference in southern Germany in the summer of 1939, when I was 14 years old, I participated as a passionate fossil collector and was proud to carry the real Steinheim cranium into the Stuttgart exhibition, where only a cast was displayed.

When the setting was moved to Tübingen, I stayed at the hostel by the Neckar river instead of with relatives. I had to pass on the subsequent excursion to Ticino for financial reasons, even though it would have been my first and - for the time being - last non-military trip abroad. But the acquaintance with the most famous German palaeontologist at the time made it possible for me to begin my studies in Tübingen (which was now the French occupation zone) immediately after the war. There, I must have greatly disappointed my esteemed mentor, Friedrich von Huene (1875-1969), as I deserted to the newly appointed Otto Heinrich Schindewolf (1896-1971) and therefore to the invertebrates.

This year's conference in my former place of work, Göttingen, is once again dedicated to Fossil Lagerstätten as in 1939, but under completely new aspects. Not being able to participate is therefore doubly painful.

Nevertheless, I want to thank the society for nominating me for the newly created Jaekel Medal.

I hope the meeting goes well.

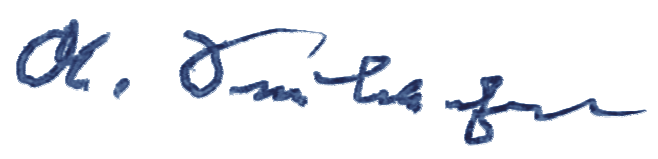

Adolf Seilacher Tübingen, August 2013 


\section{Grußwort}

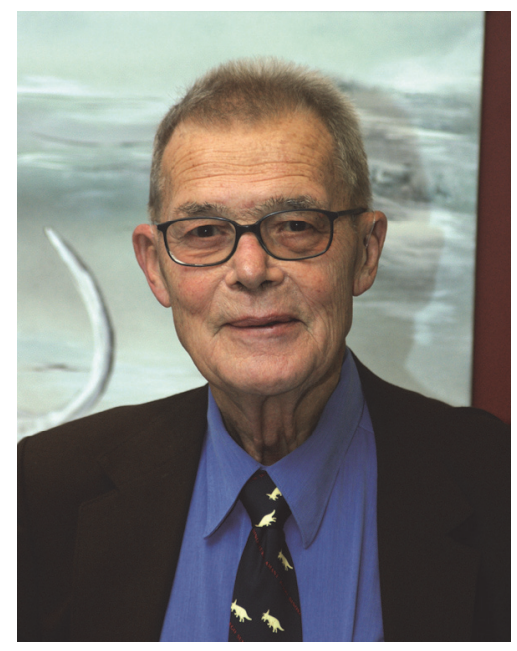

Seit ich mutig zusagte an der Tagung der Paläontologischen Gesellschaft in Göttingen teilzunehmen, hat sich leider mein Zustand sehr verschlechtert. So kann ich nicht persönlich nach Göttingen kommen. Der Paläontologischen Gesellschaft bin ich seit nunmehr 74 Jahren eng verbunden. Als ich im Sommer 1939, damals 14-jährig, von deren Tagung im Süddeutschen Raum erfuhr, war ich als passionierter Fossilien-Sammler mit dabei und stolz zur Feier des Tages den echten Steinheimer Urmenschenschädel in die Stuttgarter Schausammlung zu tragen, wo sonst bloß ein Abguss stand.

Adolf Seilacher, in Göttingen, 2010

Als der Schauplatz nach Tübingen wechselte, logierte ich statt bei Verwandten in der Jugendherberge am Neckar. Nur auf die anschließende Exkursion in den Tessin habe ich aus finanziellen Gründen verzichtet, obwohl das meine erste und vorläufig letzte nichtmilitärische Reise ins Ausland gewesen wäre. Aber die Bekanntschaft mit den damals bekanntesten deutschen Paläontologen hat es mir erlaubt, unmittelbar nach dem Krieg mit dem Studium in Tübingen (nun französische Besatzungszone) zu beginnen. Dort habe ich meinen verehrten Mentor Friedrich von Huene (1875-1969) gewiss sehr enttäuscht, als ich zu dem neuberufenen Otto Heinrich Schindewolf (1896-1971) und damit zu den Invertebraten desertierte.

Die diesjährige Tagung an meiner alten Wirkungsstätte in Göttingen gilt wieder, wie 1939, prominenten Fossil-Lagerstätten, aber unter völlig anderen Aspekten. Daran nicht teilzuhaben, ist darum doppelt schmerzlich.

Doch danke ich der Gesellschaft, dass sie mich für die neu geschaffene Jaekel-Medaille vorgeschlagen hat.

Der Tagung wünsche ich einen guten Verlauf.

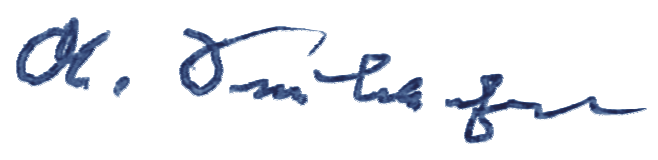

Adolf Seilacher

Tübingen, August 2013 


\title{
Abstracts of Oral \& Poster Presentations
}

\section{The precise timing of Devonian reef growth and extinctions in the Moroccan Meseta [posterpresentation]}

Sarah Z. Aboussalam ${ }^{1}$, R. Thomas Becker ${ }^{1}$, Stephan Eichholt ${ }^{1}$, Ahmed El Hassani $^{2}$, El Mustafa Benfrika ${ }^{3} \&$ Fouad El Kamel $^{4}$

${ }^{1}$ Westfälische Wilhelms-Universität Münster, Institut für Geologie und Paläontologie, Münster, Germany;

E-mails:taghani@@uni-muenster.de; rbecker@uni-muenster.de@s_eich01@uni-muenster.de

2Université Mobammed V, Institut Scientifique, Rabat,Morocco; E-mail: abmed.elhassani@gmail.com

${ }^{3}$ Université Hassan II, Faculté des Sciences Ben M'Sik, Casablanca, Morocco; E-mail: benfrikael@hotmail.com

${ }^{4}$ Université Hassan II, Faculté des Sciences Ain Chock, Casablanca, Morocco; E-mail: elkamel@fsac.ac.ma

Devonian reefs, including biostromal platforms, are widespread in the Moroccan Meseta but grew on different tectonic blocks with different palaeoecological conditions. Rapid Eovariscan block tilting led locally during growth or subsequently to the reworking or almost complete destruction of reefal complexes. Conodont sampling in reference sections for most blocks resulted in many new age data for the onset of reef growth and extinctions, with a focus on the Middle and Upper Devonian. Many localities have been wrongly dated in the past. Biostromes originated on neritic or pelagic carbonate platforms variably in the upper Eifelian (Ain Jemaa, Oulmes region) to Lower Givetian (Oued Cherrat, Jebilet, western Rehamna, Mrirt region). The peak of reef growth was reached in the Middle/Upper Givetian, followed by sudden extinction in the course of the global Frasnes Event (basal Frasnian). Only the Ain Jemaa reef survived until the end of the Lower Frasnian (global Middlesex Event). It is intriguing that there was no regional recovery despite the overall Middle/Upper Frasnian warming, which should have promoted a southwards expansion of the subtropical reef belt.

Seasonal temperatures in low latitudes during the Early Oxfordian (Late Jurassic) reconstructed via stable isotope analysis of an oyster from the Kachchh Basin, western India [posterpresentation]

\author{
Matthias Alberti ${ }^{1}$, Franz T. Fürsich ${ }^{2} \&$ Dhirenda K. Pandey ${ }^{3}$ \\ ${ }^{1}$ Christian-Albrechts-Universität, Institut für Geowissenschaften, Kiel, Germany; \\ E-mail: alberti@gpi.uni-kiel.de \\ ${ }^{2}$ Friedrich-Alexander-Universität Erlangen-Nürnberg, GeoZentrum Nordbayern, Erlangen, Germany; \\ E-mail: franzfuersich@gzn.uni-erlangen.de \\ ${ }^{3}$ University of Rajasthan, Department of Geology, Jaipur, India; E-mail: dhirendrap@ hotmail.com
}


A high-resolution stable isotope $\left(\delta^{18} \mathrm{O}, \delta^{13} \mathrm{C}\right)$ analysis of a specimen of the oyster Actinostreon marshi (J. Sowerby, 1814) from Lower Oxfordian strata of the Kachchh Basin in western India has been used to reconstruct seasonal temperature variations over a consecutive time interval of ten years. During this period, temperatures varied around a mean of $13^{\circ} \mathrm{C}$ (maximum: $15.1^{\circ} \mathrm{C}$; minimum: $11.4^{\circ} \mathrm{C}$ ) with a general low seasonality of 1 to $3^{\circ} \mathrm{C}$ in the recorded years. While the generally weak seasonality can be explained by the subtropical palaeolatitude between 25 and $30^{\circ} \mathrm{S}$, the low average temperatures are unexpected, especially when compared to studies of broadly contemporaneous fossils from Europe and the southern Malagasy Gulf which suggest much warmer conditions in these areas. It is therefore proposed that the low temperatures in the Kachchh Basin are caused by upwelling currents influencing the northwestern coast of India during the Late Jurassic, a hypothesis in accordance with previously published general circulation models.

\section{How to deal with polymorphism/intraspecific variation [oral presentation]}

\section{Melanie Altner ${ }^{1} \&$ Bettina Reichenbacher ${ }^{1}$ \\ ${ }^{1}$ Ludwig-Maximilians University, Department of Earth and Environmental Sciences, Section Palaeontology and Geobiology,Munich, Germany; E-mails:m.altner@lrz.uni-muenchen.de \& b.reichenbacher@lrz.uni-muenchen.de}

A special form of intraspecific variation is the occurrence of multi-state characters, usually termed polymorphism. Polymorphism is difficult to interpret in phylogenetic analyses and has therefore widely been ignored for phylogenetic reconstructions. However, the study of Wiens (1993) has revealed that polymorphism can be used in phylogenetic analyses when the frequencies of the respective character states are coded. We have applied this method to reconstruct the phylogenetic relations of a fossil killifish from the Upper Miocene Lukeino Formation (East Africa). The fossils show a high amount of variability within their meristic counts but also in their osteology. The here discussed polymorph characters comprise the alignment of the pterygiophores associated with the anterior dorsal fin rays, the number of preural vertebrae $(5 v s .6)$, and the shape of the proximal part of the parhypural (reduced $v s$. not reduced). We used Mesquite to evaluate the phylogenetic assignment of the fossil species within the order Cyprinodontiformes and we compared the outcome with a phylogenetic analysis not including the polymorph characters.

\section{The "Posidonia venusta" group - widespread bivalves in late Devonian and early Mississippian pelagic facies [oral presentation]}

Michael R. W. Amler ${ }^{1} \&$ Dieter Weyer ${ }^{2}$ 
${ }^{1}$ University of Cologne, Institute for Geology and Mineralogy, Cologne, Germany;

E-mail:michael.amler@uni-koeln.de

2Berlin, Germany; E-mail: dieter.weyer@t-online.de

Bivalves of the former "Posidonia venusta" group, a mixture of few well diagnosed species and some twenty taxa unstudied for 150 years named after "Posidonomya? venusta" Münster from the Clymenia limestones of Franconia (Germany), occur widespread in Late Devonian to earliest Mississippian strata within low latitude pelagic realms (Hercynian and Kulm facies). These taxa are now assigned to the bivalve genus Guerichia Rzehak, its bivalve anatomy proven by shell details and SEM observations of the shell microstructure. The group can be subdivided into some distinct taxa at the species level, which proved to be biostratigraphically important, and indicate biozones in the pelagic Late Devonian and early Mississippian crossing uninterrupted the $\mathrm{D} / \mathrm{C}$ boundary. Earlier attempts to a biostratigraphical zonation in Kazakhstan by A. M. Sadykov and Poland by H. Zakowa are successfully adapted to comparable facies in central Europe. After the Frasnian/ Famennian Event, Guericbia simorini indicates the "Nehden Stage"and "Hemberg Stage". The "Hemberg Stage" and "Dasberg Stage" are characterized by Guerichia venusta s. str.; Guericbia venustiformis indicates the "Wocklum Stage" and the D/C boundary interval, and Guerichia mariannae the early Mississippian up to the Liegende Alaunschiefer (Kahlenberg Subformation). Additional material from conodont-based bed-by-bed sampling in central Europe will be added soon for precise correlation of the proposed zonation.

\section{Stratigraphy and occurrences of the Carboniferous coral genus Cyathoclisia (Rugosa) in the British Isles [oral presentation]}

Christian Baars ${ }^{1}$

${ }^{1}$ National Museum of Wales, Cardiff, U.K.; E-mail: christian.baars@museumwales.ac.uk

The rugose coral genus Cyathoclisia Dingwall, 1926 has a wide distribution during the Lower Carboniferous of Europe and Asia. It is a characteristic element of coral faunas in the photic zone (caninid-clisiophyllid facies) during the Upper Tournaisian and an index fossil for the Ivorian substage. The taxonomy of the genus is in need of revision. Currently more than 20 species are named, the majority of which (16) from occurrences in the Ural Mountains. Many of these were erected without regard for older literature. There is a lack of careful morphological studies that would establish the ontogeny and spectrum of intraspecific morphological variation. The purpose of this publication is to review the recorded occurrences of Cyathoclisia across the British Isles, to establish the consistency of taxonomic characters of the type species by re-assessing existing museum collections, and to verify the validity of the apparent synonymy of $C$. tabernaculum with $C$. modavense Salee, 1913. This will enable further, wider revision of the genus and also, it is 
hoped, improved stratigraphic correlations on the basis of this widely distributed important genus.

\title{
New concepts in the management of museum collections (natural science) [posterpresentation]
}

Christian Baars ${ }^{1}$, Richard Bevins ${ }^{1}$, Rachael Rogers ${ }^{2}$, Jane Henderson ${ }^{3}$, Graham Oliver $^{1}$, Deborah Spillards ${ }^{1} \&$ Hefin Jones ${ }^{3}$

\author{
${ }^{1}$ National Museum of Wales, Cardiff, U.K.; \\ E-mails:christian.baars@museumwales.ac.uk; richard.bevins@museumwales.ac.uk; \\ grabam.oliver@museumwales.ac.uk.\& deborah.spillards@museumwales.ac.uk \\ ${ }^{2}$ Federation of Museums \& Art Galleries in Wales, Abergavenny, U.K.; \\ E-mail:Rachae/Rogers@monmouthshire.gov.uk \\ ${ }^{3}$ Cardiff University, Cardiff, U.K.; E-mails: HendersonLJ@cardiff.ac.uk.\&JonesTH@cardiff.ac.uk
}

Museums are guardians of knowledge. Collections - and the knowledge that goes with them - are at the heart of museums; they are the reason museums exist and what makes them unique. However, the number of specialist curators caring for natural science museum collections has fallen dramatically in Britain in recent years. In Wales, only one institution (out of a total of more than 100 with natural science specimens) still has specialist curators - the National Museum. Wales has a Museums Strategy, which includes the principle of the Distributed National Collection. This implies a shared responsibility for natural heritage. Collections telling the story of Wales are kept across the nation by a diverse range of museum institutions. The Distributed National Collection therefore advocates a coordinated approach to collecting as well as collections care as some of the benefits of the shared knowledge that comes with a distributed collection. The Linking Natural Sciences Collections in Wales project now undertakes reviews of Geology and Natural History collections across the country as a foundation to implementing this new way of managing museum collections.

\section{The earliest rugose coral [poster presentation]}

\author{
Christian Baars ${ }^{1}$, Mansoureh Ghobadi Pour ${ }^{2} \&$ Robert C. Atwood ${ }^{3}$ \\ ${ }^{1}$ National Museum of Wales, Cardiff, U.K.; E-mail: christian.baars@museumwales.ac.uk \\ ${ }^{2}$ Golestan University, Gorgan, Iran; E-mail:mghobadipoun@yahoo.co.uk \\ 3Diamond Light Source,Didcot, U.K.; E-mail:Robert.Atwood@diamond.ac.uk.
}

Rugose corals are thought to have evolved from an ancestral anthozoan during the Middle Ordovician Epoch even though there is a lack of fossil evidence for the early evolutionary history of the Rugosa. Previously documented species of early rugose corals are all assigned to the main orders Calostylina, Streptelasmatina, 
Cystiphyllina and Stauriina, which had all evolved by the late Sandbian. Two specimens of Lambelasma? sp., a new rugose coral, was recovered from the upper Darriwilian (Middle Ordovician) part of the Shirgesht Formation of Central Iran. One of the fossils, partly embedded in rock matrix, was examined using synchrotron X-ray tomography, which is here demonstrated to be a useful tool in palaeontological taxonomic studies. The new fossils form part of a mid-latitude Gondwana fauna and are the earliest record of rugose corals to date. The specimens combine features of both the Streptelasmatina and Calostylina, but are here assigned to the Lambelasmatidae (Calostylina) on the grounds of a very deep calice, the pinnate arrangement of the septa and a lack of synapticulae and tabulae.

\section{Fossil seedlings from the Triassic of France giving first insights into the ontogeny of a fossil ginkgophyte [oral presentation]}

Kathleen Bauer ${ }^{1,2}$, Evelyn Kustatscher ${ }^{1,2}$, Léa Grauvogel-Stamm ${ }^{3}$ \& Michael Krings ${ }^{2}$

${ }^{1}$ Naturmuseum Südtirol, Bolzano/Bozen, Italy; E-mails: Kathleen.Bauer@naturmuseum.it \& Evelyn.Kustatscher@naturmuseum.it

${ }^{2}$ Ludwig-Maximilians-Universität München, Department für Geo- und Umweltwissenschaften, Paläontologie und Geobiologie, and Bayerische Staatssammlung für Paläontologie und Geologie, München, Germany;

E-mail:m.krings@lr:uni-muenchen.de

3Strasbourg, France; E-mail: lea.stamm@gmail.com

Documented evidence of early ontogeny of fossil ginkgophytes is lacking to date. A collection of Anisian fossils from the Vosges (France) assembled by the late Louis Grauvogel (Strasbourg, France) contains several exquisitely preserved seedlings assignable to the ginkgophytes based on leaf morphology. The seedlings are preserved at different stages of their ontogenetic development (i.e. from germination to the appearance of the first fully differentiated leaves), and thus provide a unique opportunity to reconstruct the early ontogeny of a fossil ginkgophyte. The ontogenetic development in this fossil ginkgophyte is notably similar to that observed in the extant Ginkgo biloba. This suggests a close biological relationship. Although the precise systematic position of the fossil seedlings within the ginkgophytes remains unresolved, they permit a direct correlation of the ontogeny of an extinct taxon with its single living relative, and thus represent a benchmark discovery in the study of ginkgophytes. 


\title{
Intraspecific variability in fossil ginkgophyte leaves - was it as high as in Ginkgo biloba? [posterpresentation]
}

\author{
Kathleen Bauer ${ }^{1,2}$, Evelyn Kustatscher ${ }^{1,2} \&$ Michael Krings ${ }^{2}$ \\ 'Naturmuseum Südtirol, Bolzano/Bozen, Italy; E-mail: Katbleen.Bauer@naturmuseum.it \& \\ Evelyn.Kustatscher@naturmuseum.it \\ ${ }^{2}$ Ludwig-Maximilians-Universität München, Department für Geo- und Umweltwissenschaften, Paläontologie und \\ Geobiologie, and Bayerische Staatssammlung für Paläontologie und Geologie, München, Germany; \\ E-mail:m.krings@lr:uni-muenchen.de
}

The fossil record of ginkgophytes mainly consists of impression and compression fossils, only rarely with cuticles. However, identification of individual taxa based exclusively on macromorphology is difficult, primarily because leaf morphology may vary greatly within a single species. It has been speculated that all ginkgophytes are highly variable with regard to leaf morphology because the group as a whole is relatively conservative. Nonetheless, numerous fossil taxa have been established that are defined based on leaf morphology. To determine whether fossil ginkgophytes are more or less variable with regard to leaf morphology than G. biloba, morphological parameters of G. biloba leaves from different localities worldwide were taken and compared to fossil ginkgophytes. We found that many fossil taxa are in fact highly variable with regard to certain leaf morphological parameters. On the other hand, fossil shoots with attached Baiera digitata leaves indicate that these leaves were distinctly less variable than G. biloba. As a result, we cannot rule out that some fossil ginkgophytes were less variable intraspecifically than G. biloba.

\section{Bernettia reconsidered: first record of a cone-like structure [posterpresentation]}

Kathleen Bauer ${ }^{1,2}$, Evelyn Kustatscher ${ }^{1,2}$, Michael Krings ${ }^{2} \&$ Johanna H. A. Van Konijnenburg-van Cittert ${ }^{3,4}$

\author{
1Naturmuseum Südtirol, Bolzano/Bozen, Italy; E-mails: Katbleen.Bauer@naturmuseum.it \& \\ Evelyn.Kustatscher@naturmuseum.it \\ ${ }^{2}$ Ludwig-Maximilians-Universität München, Department für Geo- und Umweltwissenschaften, Paläontologie und \\ Geobiologie, and Bayerische Staatssammlung für Paläontologie und Geologie, München, Germany; \\ E-mail:m.krings@lrz.uni-muenchen.de \\ ${ }^{3}$ Laboratory of Palaeobotany and Palynology, Utrecht, The Netherlands; E-mail:J.H.A.vanKonijnenburg@uu.nl \\ ${ }_{4}^{4}$ National Centre for Biodiversity 'Naturalis', Leiden, The Netherlands
}

Bernettia inopinata, an enigmatic leaf-like fossil characterized by a central cluster of small, rhombohedral, pillow-like reproductive units, occurs quite abundantly in the lower Jurassic of Franconia, Germany. The fossil is usually viewed as female fructification of a gymnosperm. However, the precise systematic affinities remain unresolved, due in part because the structures have to date only been found isolated. 
A reinvestigation of some historic specimens together with several newly discovered strobili composed of B. inopinata from Pechgraben near Bayreuth (Germany) provide new insights into the morphology of this enigmatic fossil. Bernettia inopinata was constructed of two superpositioned leaf-like structures, one of which (the lower) bearing the cluster of pillow-like reproductive units, the upper functioning as a cover. The strobilus consists of numerous B. inopinata complexes arranged helically around a central axis. Bernettia inopinata has been interpreted as a gnetalean female reproductive structure. However, if the interpretation of the pillow-like reproductive units as ovules embedded in a gynoecial crust is accurate, a relationship to the Bennettitales is also possible.

\title{
The global carbonate crisis at the Devonian-Carboniferous transition in Morocco [oral presentation]
}

\author{
R. Thomas Becker ${ }^{1}$, Sarah Z. Aboussalam ${ }^{1}$, Sven Hartenfels ${ }^{1}$, Ahmed E1 \\ Hassani $^{2}$ \& Lahcen Baidder ${ }^{3}$ \\ ${ }^{1}$ Westfälische Wilhelms-Universität Münster, Institut für Geologie und Paläontologie, Münster, Germany; \\ E-mails:rbecker@uni-muenster.de; taghani@@uni-muenster.de \& shartenf@uni-muenster.de \\ ${ }^{2}$ Université Mohammed V, Institut Scientifique, Rabat, Morocco; E-mail: abmed.elhassani@gmail.com \\ ${ }^{3}$ Université Hassan II, Faculté des Sciences, Departement de Géologie, Casablanca, Morocco; \\ E-mail:lbaidder@gmail.com
}

The Hangenberg Event near the Devonian-Carboniferous boundary led globally to a complete reef extinction and a short or long-lasting interruption of carbonate accumulation in almost all marine facies settings. This poorly understood D/C Carbonate Crisis (DCCC) is underlined by biostratigraphical dating of FamennianTournaisian successions in the Anti-Atlas and Meseta of Morocco. In the SE AntiAtlas, the last cephalopod limestones of the Tafilalt Platform terminate slightly before the Hangenberg Black Shale and are overlain by thick clastic wedges. Apart from single thin limestones and siderite concretions (Kaiser et al. 2011), rare pelagic micrites do not re-appear before the end-Tournaisian. In the northern Maider, exceptional top Famennian-basal Tournaisian crinoid shoals formed around islands. They were only briefly interrupted by the DCCC but terminated within the Lower Tournaisian. In the Mesta autochthonous carbonates were uncommon between the upper Famennian and Upper Viséan. Exceptions are a thin brachiopod limestone of the Benahmed region (kockeli Zone) and Middle Tournaisian sideritic goniatites (Ain Aouda) or brachiopod limestones (Sidi Jilali Limestone). 


\title{
Dating the diversification of Ascomycota lineages using molecular data and fossils from amber and chert [oral presentation]
}

Christina Beimforde ${ }^{1}$, Kathrin Feldberg ${ }^{2}$, Stephan Nylinder 3 , Jouko Rikkinen ${ }^{4}$, Hanna Tuovila ${ }^{4}$, Heinrich Dörfelt ${ }^{5}$, Matthias Gube ${ }^{5}$, Daniel J. Jackson ${ }^{1}$, Joachim Reitner $^{1,6,7}$, Leyla J. Seyfullah ${ }^{1}$ \& Alexander R. Schmidt ${ }^{1}$

${ }^{1}$ Georg-August-Universität Göttingen, Courant Research Centre Geobiology, Göttingen, Germany;

E-mails: christina.beimforde@geo.uni-goettingen.de; djackso@gwdg.de; jreitne@gwdg.de; leyla.seyfullab@geo.unigoettingen.de \& alexander.schmidt@geo.uni-goettingen.de

${ }^{2}$ Ludwig-Maximilians-Universität München, Department für Biologie, Systematische Botanik. und Mykologie,

München, Germany; E-mail: k.feldberg@biologie.uni-muenchen.de

3Swedish Museum of Natural History, Department of Botany, Stockholm, Sweden; E-mail: stephan.nylinder@nrm.se

${ }^{4}$ University of Helsinki, Department of Biosciences, Helsinki, Finland; E-mails:jrikkine@mappi.belsinki.fi \& banna.tuovila@helsinki.fi

${ }_{5}^{5}$ Friedrich-Schiller-Universität, Microbial Communication, Jena, Germany; E-mails: Heinrich.Doerfelt@t-online.de \&atthias.Gube@uni-jena.de

${ }^{6}$ Georg-August-Universität Göttingen, Geowissenschaftliches Zentrum, Abt. Geobiologie, Göttingen, Germany

${ }^{7}$ Georg-August-Universität Göttingen, Geowissenschaftliches Museum, Göttingen, Germany

The phylum Ascomycota is by far the largest and most diverse group in the fungal kingdom. Important mutualistic associations such as mycorrhizae and lichens have evolved in this group of fungi. While several lines of evidence indicate that fungi are a very ancient group, only a few attempts have been made to date the origin of main ascomycete lineages. This is primarily due to the lack of satisfactory fossil data for the Ascomycota. For this reason, we evaluated all of the oldest available ascomycete fossils from amber (Albian to Miocene) and chert (Devonian and Maastrichtian) representing four major lineages: Lecanoromycetes, Laboulbeniomycetes, Dothideomycetes, and Eurotiomycetes. We assembled a multi-gene data set (18S rDNA, 28S rDNA, RPB1 and RPB2) from a total of 145 taxa representing all main groups of the Ascomycota and utilized multiple fossil calibrations solely from within the Ascomycota to estimate the divergence times with BEAST. Our results suggest an initial diversification of ascomycetes in the Cambrian which proceeded continuously throughout the Phanerozoic. We suggest that the ecological diversity within each lineage ensured that at least some taxa of each group were able to survive global crises such as mass extinctions and rapidly recovered afterwards.

\section{Microfacies analysis of dinosaur-bearing marine limestones from the Langenberg-Quarry (Lower Saxony, Germany) [posterpresentation]}

\author{
Michaela Berensmeier ${ }^{1}$, Oliver Wings ${ }^{2,3}$ \& Gianluca Frijia ${ }^{1}$ \\ ${ }^{1}$ Universität Potsdam, Institut für Erd- und Umweltwissenschaften, Potsdam, Germany; \\ E-mails:berensme@uni-potsdam.de \& frijia@geo.uni-potsdam.de \\ 2Niedersächsisches Landesmuseum Hannover, Hannover, Germany; E-mail:dr.wings@gmail.com
}


The Kimmeridgian limestones from Langenberg area (Harz Mountains, Germany) show not only a varied marine fauna, but also remains of the terrestrial sauropod dinosaur Europasaurus. In order to understand the taphonomy of this exceptional locality, we performed a detailed microfacies analysis of a four meter interval which comprises seven limestone and marly limestone beds. The middle part of this profile contains the "Dinobank"-layer with Europasaurus. The first 3 beds (first $2 \mathrm{~m}$ ) are partly laminated peloidal-cortoids-bioclastic wackestone/packstone with abundant quartz, pyrite and glauconite grains. Conversely, the last 3 beds are bioclastic-intraclastic packstone with common coal debris and less and smaller quartz crystals. An intense bioturbation and incipient dolomitization of the matrix is also present. The "Dinobank" itself is a bioclastic packstone with small bivalves, gastropods and charophytes. Non skeletal grains are represented by intraclasts; abundant quartz grains, coal fragments and pyrite crystals are also present. Our findings indicate that the Langenberg area was, 154 millions of years ago, a tidal zone with a nearby river inlet.

\title{
The delayed explosion: Cambrian bryozoans remain yet to be found ! [oral presentation]
}

\author{
Björn Berning ${ }^{1}$, Paul D. Taylor ${ }^{2} \&$ Mark A. Wilson ${ }^{3}$ \\ ${ }^{1}$ Upper Austrian State Museum, Geoscience Collections, Linz, Austria; E-mail: b.berning@landesmuseum.at \\ 2Natural History Museum, London, U.K.; E-mail: pdt@nhm.ac.uk \\ ${ }^{3}$ College of Wooster, Department of Geology, Obio, U.S.A.; E-mail: mwilson@wooster.edu
}

The undisputed fossil history of the Bryozoa begins in the Early Ordovician. Nevertheless, several Cambrian fossils over the years have been attributed to this phylum, including most recently Pywackia, a Late Cambrian fossil from southern Mexico. While Pywackia does bear a resemblance to some cryptostome bryozoans, it is sufficiently different in detail to refute its identity as a bryozoan. But if Pywackia is not a bryozoan then what is it? A comparison with the skeleton of a modern sea pen from Singapore suggests that Pywackia may instead be the axis of a pennatulacean octocoral. The Singapore sea pen is an un-named species of Lituaria, which belongs to Veretillidae, a primitive family of pennatulaceans with radially arranged zooids. While the fossil record of pennatulaceans has customarily been extended back to the Ediacaran to include such genera as Charnia and Rangea, recent interpretations have excluded these problematical fossils from Pennatulacea. This leaves fossils from the Late Cretaceous as the oldest known pennatulaceans. If Pywackia is really a pennatulacean, then a 400 million year gap in the fossil record must be explained. 


\title{
A permineralized royal fern (Osmundaceae) from the Jurassic of Skåne, Sweden [oral presentation]
}

\author{
Benjamin Bomfleur ${ }^{1} \&$ Stephen McLoughlin ${ }^{1}$ \\ 1 'Swedish Museum of Natural History, Department of Palaeobotany, Stockholm, Sweden; \\ E-mails:benjamin.bomfleun@nrm.se\&steve.mclougblin@nrm.se
}

Surprisingly, no anatomically preserved rhizomes of the Osmundales have yet been reported from the Mesozoic of Europe, even though their distinctive foliage (Cladophlebis) and spores (e.g., Osmundacidites) are very common in Triassic and Jurassic deposits. We here present a well-preserved calcified rhizome from Jurassic pyroclastic deposits of Skåne that constitutes the first permineralized osmundalean fern from the European Mesozoic. The stem contains an ectophloic-dictyoxylic siphonostele with a homogeneous parenchymatous pith. The xylem cylinder is about $10-15$ cells thick and dissected by numerous, narrow leaf gaps. The cortex is differentiated into a thin, inner parenchymatous layer and a thicker, sclerified outer layer. The stem is surrounded by a mantle of tightly packed leaf bases and rootlets, both of which contain prominent sclerenchyma. Leaf traces contain a crescentshaped bundle with only a single protoxylem strand at the point of departure from the stem. The specimen likely represents a new species within the problematic genus complex including the fossil taxa Asbicaulis and Millerocaulis as well as modern Osmunda and Osmundastrum.

\section{The 'Critical Temperatures Approach' in palaeoecology and palaeo- climatology [oral presentation]}

\section{Thomas C. Brachert ${ }^{1}$}

\section{${ }_{1}^{1}$ Universität Leiprig, Institut für Geophysik. und Geologie, Leipzig, Germany; E-mail: brachert@uni-leiprig.de}

Neritic carbonate production is highly diverse, and both skeletal and non-skeletal in origin. Non-skeletal material seems to form in warm-water settings only, and as such to be diagnostic for the 'tropical zone'. In contrast, the skeletal factory extends from the equator to the polar zone and is highly diverse. Two large biotic systems have been identified for the warm water (Photozoan carbonates) and coolwater zones (Heterozoan carbonates). Because this binary classification is too simple for significant palaeoenvironmental and paleoclimatic reconstructions, various attempts have been made to refine the classification.

In this contribution I will use the 'Critical Temperatures Approach' (CTA) into palaeoecology and carbonate sedimentology to make more specific temperature estimates from shallow-water carbonates. We assume maximal carbonate precipitation of the calcifying biota to occur at their specific optimum temperature and to decrease towards their minimum and maximum temperature of distribution. Identification whether maximum calcification occurred in winter or summer allows 
estimates to be made, whether a taxon occurred under optimal or warm/cold suboptimal conditions. I will illustrate the potential of the CTA with two case studies on carbonate production in the Photozoan System (Plio-Pleistocene/ Florida, Late Miocene/Mediterranean region). In these, the model is relevant for all poikilothermic carbonate producers in reefs and platforms, and has implications for judging geographic distributions and causes of declining growth of corals, benthic carbonate communities and entire carbonate systems. With regard to the causes underlying expansion and demise of carbonate platforms and reefs in geological history, I expect the model predictions to help for a deeper understanding of biotic responses during hyperthermals or coolings, and possibly also for identifying regions in the modern ocean where corals are endangered or taking advantage of global warming.

\section{Functional aspects of Haldanodon (Docodonta, Mammaliaformes) molar dentition [poster presentation]}

Janka J. Brinkkötter ${ }^{1} \&$ Thomas Martin $^{1}$

${ }^{1}$ Rheinische Friedrich-Wilhelms-Universität, Steinmann-Institut für Geologie, Mineralogie und Paläontologie, Bonn, Germany; E-mails:j.brinkkoetter@uni-bonn.de s tmartin@uni-bonn.de

Docodonts are mammaliaforms that developed a talonid-like structure in the lower and a protocone-like cusp in the upper molars independently of Tribosphenida. To determine the amount of crushing in the mesially situated "pseudotalonid" of the docodonts, a large number of isolated teeth, as well as upper and lower tooth rows of the Kimmeridgian Haldanodon from the Guimarota coal mine (Portugal) were studied. An analysis of the chewing cycle with the Occlusal Fingerprint Analyser (OFA), based on 3D models derived from synchrotron scans and the mapping of wear facets and striations by SEM images, revealed low crushing activity within the "pseudotalonid" because the "pseudoprotocone" occludes mesiolingually of it. On the other hand, cusp ' $\mathrm{b}$ ' of the lower molar performs a considerable crushing function in the distally situated "pseudotrigon" of the upper molar. Noteworthy is also an "Overbite" in the molars of Haldanodon, caused by the occlusion of main cusp 'a' of the lower molar beyond the dental crown-root-boundary of the upper molar, which is accommodated by pits in the maxilla between the upper molars. 
New palynological evidence regarding age and environment of the Hunsrückschiefer, Lower Devonian, Rheinisches Schiefergebirge, Germany [posterpresentation]

\author{
Rainer Brocke ${ }^{1}$, Volker Kneidl ${ }^{2}$, Volker Wilde ${ }^{1} \&$ Walter Riegel $^{1,3}$ \\ 'Senckenberg Forschungsinstitut und Naturmuseum, Abt. Paläontologie und Historische Geologie, Frankfurt/M., \\ Germany; E-mails: Rainer.Brocke@Senckenberg.de $心 V o l k e r . W i l d e @ S e n c k e n b e r g . d e$ \\ 2Bad Kreuznach, Germany \\ ${ }^{3}$ Georg-August-Universität Göttingen, Geowissenschaftliches Zentrum, Abt. Geobiologie, Göttingen, Germany \\ E-mail:wriegel@gwdg.de
}

The Devonian Hunsrückschiefer includes some of the most outstanding Palaeozoic Fossil Lagerstätten in Europe, e.g. Bundenbach, which allow a rare glimpse into the unique world of Lower Devonian seas. However, since reliable biostratigraphic markers are rare and tectonic deformation is complex, the exact age range of the Hunsrückschiefer and facies equivalents is not known. Controversies also exist over interpretations of the depositional environment.

Palynology, thus far, provided ambiguous evidence mainly from marginal sites. A section at Siesbach near Idar-Oberstein now yielded a diverse palynomorph assemblage including Retusotriletes, Apiculiretusispora, Emphanisporites and small tetrads. Acritarchs are represented by the genera Veryhacbium, Micrhystridium, Baltisphaeridium and Multiplicisphaeridium. Due to high thermal alteration, identifications are based on SEM and infrared microscopy. The simple morphologies and small size of spores suggest a deep early Emsian or latest Siegenian age. Since the marker species of the Klerf Formation, Verruciretusispora dubia, is missing, a late Lower Emsian age can be excluded for the Siesbach section. However, $V$. dubia, has been recorded from other sites suggesting that the Hunsrückschiefer ranges through the Lower Emsian into the Upper Emsian. Future palynological studies are combined with lithofacies analysis and the geochemistry of MORB-type metabasites.

\title{
A historical perspective on the completeness of the fossil record of pelycosaurian-grade synapsids [poster presentation]
}

\section{Neil Brocklehurst ${ }^{1} \&$ Jörg Fröbisch ${ }^{1}$}

${ }^{1}$ Humboldt-Universität zu Berlin, Museum für Naturkunde, Leibniz-Institut für Evolutions-und
Biodiversitätsforschung, Berlin, Germany; E-mails: neil.brockleburs@@mfn-berlin.de \& joerg.froebisch@mfn-berlin.de

While it is well known that the fossil record is incomplete, it is still debated exactly to what extent; is the current record adequate for inferring macroevolutionary patterns? Is the fossil record improving? And are there still many more discoveries to be made?

Here, the fossil record of the pelycosaurian-grade synapsids is examined from a historical perspective. A collector's curve is generated in order to show the history 
of discovery. To assess completeness and whether it has improved over time, the relative completeness index ( $\mathrm{RCI}$ ) is applied to a supertree and then to pruned versions representing each year as far back as 1878 . Finally, a taxic diversity curve is compared to pruned curves including known taxa as far back as 1853 .

Discovery of pelycosaurs has slowed in recent years, implying that the number of species is approaching the asymptote of the maximum "knowable record". Still, the RCI indicates that there are substantial gaps in the record, although the score has improved since 1913. The current diversity curve correlates strongly with diversity curves representing knowledge as far back as 1913, indicating that the curve is afflicted by the same biases.

\title{
Reconsideration of phylogenetic approaches for character-rich tetrapod tracks [oral presentation]
}

\author{
Michael Buchwitz ${ }^{1} \&$ Sebastian Voigt ${ }^{2}$ \\ ${ }^{1}$ Technical University Bergakademie Freiberg, Institute of Geology, Freiberg/Sa., Germany; \\ E-mail: mbuchwit:@web.de \\ ${ }^{2}$ Geoskop Urweltmuseum/Burg Lichtenberg (Pfali), Thallichtenberg, Germany; \\ E-mail:s.voigt@pfalzmuseum.bv-pfal:.de
}

A phylogenetic interpretation of tetrapod tracks is often limited by the number of step cycles at hand as well as the insufficient matchability between tracks and potential trackmakers. The latter is a less severe problem in case of character-rich ichnotaxa, such as Late Paleozoic non-amniote and basal amniote tracks, which are in the focus of the present study. Approaches to the phylogenetic interpretation of trackway data may include (1) the mapping of trackway features on an existing phylogenetic tree of corresponding trackmakers and (2) cladistic analyses of the ichnotaxa themselves based on qualitative and quantitative imprint and trackway characteristics (results are afterwards related to the phylogeny of trackmakers). Both approaches yield the possibility to infer the evolution of locomotional traits as a complement to the functional interpretation of the trackmakers' skeletal morphologies. A further idea for the trackway-based cladistic approach (2) is the approximate assignment of a producer group to ichnotaxa without matching related body fossils.

\section{Rove beetles roving in deep time: Chinese Mesozoic fossils tell a story (Coleoptera: Staphylinidae) [oral presentation]}

\section{Cai Chenyang ${ }^{1} \&$ Huang Diying $^{1}$}

${ }^{1}$ Chinese Academy of Sciences, Nanjing Institute of Geology and Palaeontology, State Key Laboratory of Palaeobiology and Stratigraphy, Nanjing, P. R. of China; E-mails: caichenyang1988@163.com \& buangdiying@sina.com 
With over 58,000 described species, the beetle family Staphylinidae is the largest beetle family in the animal kingdom and occurs worldwide. It is divided into one extinct and 32 extant subfamilies varying in size from a single modern species (Empelinae, Neophoninae, and Solieriinae) to over 15,000 (Aleocharinae), covering the globe in a varied patchwork of widespread and narrowly distributed groups. Recently discovered and described Mesozoic fossils from northeastern China, including more than 500 impression fossils from the Middle Jurassic Daohugou biota (Jiulongshan Formation at Daohugou, Ningcheng County, Inner Mongolia; $\sim 165 \mathrm{Ma}$ ), the Early Cretaceous Jehol biota (Yixian Formation at Huangbanjigou and Liutiaogou of Beipiao City, Liaoning Province and Ningcheng County, Inner Mongolia; $\sim 125 \mathrm{Ma}$ ), and the Lower Cretaceous Lushanfen Formation (western Beijing), represent 11 extant subfamilies. Of them, six subfamilies (Apateticinae, Glypholomatinae, Olisthaerinae, Omaliinae, Tachyporinae and Trigonurinae) are known from the Daohugou biota; six subfamilies (Aleocharinae, Omaliinae, Oxyporinae, Oxytelinae, Staphylininae and Tachyporinae) from the Jehol biota; and three subfamilies (Megalopsidiinae, Oxytelinae and Staphylininae) from Lushangfen Formation. More importantly, Apateticinae, Glypholomatinae and Megalopsidiinae stand for the first fossil record in the world; Aleocharinae, Tachyporinae (from Daohugou) and Trigonurinae represent the oldest fossil record for the subfamily. The findings suggest that some now narrowly distributed groups were much more widespread than previously thought. These fossils contribute significantly to understanding the origin and early evolution of some staphylinid subfamilies. In addition, they increase the known antiquity of numerous higher taxa (subfamilies). Moreover, these Mesozoic fossils necessitate reconsideration of the historical biogeography of the whole family, contribute significantly to understanding the morphological evolution of Staphylinidae, and serve as unique time controls for phylogenetic studies in the future.

\title{
Holocene Molluscs in Luotuodun and Xixi of Yixing City, Jiangsu Province [poster presentation]
}

\author{
Cai Huawei ${ }^{1}$, Huang Baoyu ${ }^{1}$, Zhu Xianggen ${ }^{1}$, Lin Liugen ${ }^{2} \&$ Tian Mingli $^{2}$ \\ ${ }^{1}$ Chinese Academy of Sciences, Nanjing Institute of Geology and Palaeontology, Nanjing, P. R. of China; \\ E-mail: bwcai@nigpas.ac.cn \\ ${ }^{2}$ Archaeological Institute of the Nanjing Museum, Nanjing, P. R. of China
}

There are abundant fossil specimens in Luotuodun and Xixi historical sites of Yixing City, Jiangsu Province. Except for molluscs, plants, spores and pollens, insects and vertebrates are also found there. In total 8 genera and 17 species of molluscs from these two sites are presently studied, including one new species, Corbicula yixingensis Huang \& Cai. It can be divided into three assemblages from Unionidae and Corbiculidae of Bivalvia, and Viviparidae of Gastropoda. (A) Cuneopsis-Unio Assemblage. The elements of this old assemblage extend from the 
Miocene to Holocene, although there are few specimens of them. For example, Cuneopsis spocki Leroy was first found from the Tortonian (Miocene) in Erlian of Xilinguole County, Inner Mongolia; Unio tschiliensis Sherany was found from Early Pliocene strata in Chadaokou of Zhangiiakou City, Hebei Province. These two species do not extend to present time. (B) Arconaia-Lamprotula Assemblage. The present assemblage was distributed in rivers, lakes, ponds and reservoirs from Early Quaternary to present time. Arconaia laneceolata (Lea) was found from the Lower Pliocene in southwest Qianji of Suyang County, Jiangsu Province. Lamprotula (Sinolamprotula) leai (Gray) was found from the Lower Pliocene in Sanmenxia City, Henan Province. (C) Corbicula-Bellamya Assemblage. There are numerous specimens of species of the present assemblage, which extends for a long period in geological time, was widely distributed, and adapted strongly with environmental changes. Corbicula largillierti Heude was found from the Late Neogene to present time. For example, it was found from the Lower Pliocene in Yuanqu of Shanxi Province and Dali of Shanxi Province, but blooms in the Holocene in Jintan, Jiangyin and Yixing of Jiangsu Province. Possibly originated from Inner Mongolia of China, then transferred westward and southward, Corbicula largillierti Heude is a typical species broadly distributed in Tai Lake, Dongting Lake, Boyang Lake and connected rivers of the Changjiang valley in present time. Bellanmya parificata (Heude) and B. quadrata (Benson) were found from the Holocene to present time in a suburb of Guilin City, Guangxi Province.

\title{
The Capitanian C-isotopic excursion and its geological implications for the pre-Lopingian event in South China [oral presentation]
}

\author{
Cao Changqun ${ }^{1}$, Zhang Mingyuan ${ }^{1}$, Shen Shuzhong ${ }^{1} \&$ Zheng Quanfeng $^{1}$ \\ ${ }^{1}$ Chinese Academy of Sciences, Nanjing Institute of Geology and Palaeontology, State Key Laboratory of Palaeobiology \\ and Stratigraphy, Nanjing, P. R. of China; E-mail:cqcao@nigpas.cas.cn
}

The Kamura Cooling Event, which was termed by Isozarki (2007) with extremely high C-isotopic values of $\sim 5-6 \%$, has been constrained in the Yabeina-dominant interval in the Permian Capitanian strata in SW Japan and Central Croatia areas. The Yabeina fossil interval could be correlated with the Yabeina-Neomisellina zone in the Late Maokou Formation in southern China, which is not precise enough to be constrained within the Capitanian conodont zones such as in the GSSP Section of Penglaitan. Furthermore, no extremely high C-isotopic data have been published to document the Kamura record in the Capitanian marine strata in southern China until now. Therefore, its absence in southern China of the Capitanian Kamura cooling event marked with extremely high $\mathrm{C}$-isotopic values has blocked the discussions on effects of a cooling event and the occurrence of a super-anoxic ocean around the world, especially due to the lack of temporal correlation with constraints of Capitanian conodont zones. 
Recently, new data of Permian Capitanian conodont zones and C-isotopic excursions have been obtained in the Rencunping (RCP) Section in Hunan Province. The middle Permian Maokou Formation in this section could be subdivided lithologically into three units titled as: Low marl Unit, Middle "Kufeng" siliceous (argillaceous) Unit, and Upper limestone Unit. The Capitanian strata almost entirely covered the Middle and Upper units of Maokou Fm., with conodont zone constraints from the Jinogondollela postserrata to J. xuanhanensis, but is absent from the Capitanian uppermost zones of J. granti and Clarkina postbitteri hongshuiensis. The Cisotopic excursion in the Capitanian strata shows an extremely high value interval (higher than $5 \%$ ) from the end of J.altudaensis zone to the beginning of J. xuanhanensis zone spanning the entire J. prexuanhanensis zone. The overlying strata within the J. xuanhanensis zone presented long-term negative excursions around a value of $-2 \%$. We suggested that the extremely high $\mathrm{C}$-isotopic values within the J. prexuanhanensis zone should be correlated to the Kamura event interval, but without the occurrence of organic-rich deposits as were preserved in SW Japan and Central Croatia. The overlying massive limestone within the J. xuanhanensis zone with sparse fossil records should indicate the "Barren Zone" in the pre-Lopingian extinction period. Strangely, the "Kamura interval" in the RCP Section occurred within the interbedded interval of dolomitic limestone and thin cherty-nodule layer, which was underlying the organic-rich strata of siliceous (argillaceous) rock sets within the J. postserrata zone. Its inconsistence between the extremely high Cisotopic values and the occurrence of organic-rich rock set in the RCP Section was totally different from the appearances in SW Japan and Central Croatia. Therefore, we doubted that the Kamura event resulted from the high primary productivities under atmospheric cooling conditions (Isozarki 2007). We prefer to suggest that it should have resulted from the prevailing oceanic bottom cooling currents with enhanced oceanic stratification, but in atmospheric warming conditions. This suggestion was supported additionally by the published O-isotopic data from Chen (2012) that inferred an atmospheric warming trend during the Capitanian. The following $\mathrm{C}$-isotopic negative excursions around $-2 \%$ in J. xuanhanensis zone might have resulted from the effects of sulfate reduction of bacteria (SRB) during the Barren Zone of the pre-Lopingian, which were present in plenty of dolomitic lumps in the massive limestone. The finding of the C-isotopic Kamura event in the RCP Section might mean there developed an open channel in the RCP area to connect the paleo-Tethysian Ocean in the early Capitanian, but there is no previously documented data from other areas of southern China.

\title{
Keep it cool ? - Investigating the palaeoclimate of the Upper Jurassic Wattendorf Plattenkalk (Southern Germany) [oral presentation]
}

\author{
Patrick Chellouche ${ }^{1}$, Matthias Alberti ${ }^{2}$ \& Franz T. Fürsich ${ }^{1}$ \\ ${ }^{1}$ Friedrich-Alexander-Universität Erlangen-Nürnberg, GeoZentrum Nordbayern, Fachgruppe Paläoumwelt, \\ Erlangen, Germany; E-mails: Patrick.Chellouche@fau.de \&o franzfuersich@gzn.uni-erlangen.de
}


${ }^{2}$ Christian-Albrechts-Universität, Institut für Geowissenschaften, Kiel, Germany;

E-mail:alberti@gpi.uni-kiel.de

Stable isotope analyses of calcitic invertebrate fossils from the Upper Kimmeridgian Wattendorf Plattenkalk Konservat-lagerstätte show an unexpected deviation from the Upper Jurassic greenhouse-world climate model. Benthic faunal elements (brachiopods, oysters) from the sponge-microbial reefs surrounding the plattenkalk basin show a mean palaeotemperature of $\sim 17^{\circ} \mathrm{C}$ with an annual fluctuation of $8.5^{\circ} \mathrm{C}$ in near-surface waters. Palaeotemperatures as low as $8.5^{\circ} \mathrm{C}$ were recorded by individuals of the belemnite Hibolithes semisulcatus, retrieved from the plattenkalk deposit. The sclerochronological analysis of one belemnite rostrum suggests that these animals spent part of their life in shallow waters comparable to the depth inhabited by the benthic fauna but retreated to deeper habitats characterized by lower temperatures for prolonged time periods. The study indicates that the formation of plattenkalk deposits neither depended on, nor was restricted to, areas of tropical water temperatures, which were in the past considered as being characteristic for this kind of lagerstätte.

\section{Permian ice volume and palaeoclimate history: insights from oxygen isotopes of conodont apatite [oral presentation]}

Chen Bo ${ }^{1,2}$, Michael M. Joachimski ${ }^{2}$, Shen Shuzhong ${ }^{1}$, Lance L. Lambert ${ }^{3}$, Lai Xulong ${ }^{4,5}$, Wang Xiangdong ${ }^{1}$, Chen $J^{6}{ }^{6} \&$ Yuan Dongxun ${ }^{1}$

${ }^{1}$ Chinese Academy of Sciences, Nanjing Institute of Geology and Palaeontology, State Key Laboratory of Palaeobiology and Stratigrapby, Nanjing, P. R. of China; E-mail: chenbo@nigpas.ac.cn

${ }^{2}$ Friedrich-Alexander University Erlangen-Nürnberg, Geo-Center of Northern Bavaria, Erlangen, Germany

${ }^{3}$ The University of Texas, Department of Geological Sciences, San Antonio, Texas, U.S.A.

${ }^{4}$ China University of Geosciences, State Key Laboratory of Biogeology and Environmental Geology, Wuban, P. R. of China

${ }^{5}$ China University of Geosciences, Faculty of Earth Science, Wuban, P. R. of China

${ }^{6}$ Chinese Academy of Sciences, Guangzhou Institute of Geochemistry, State Key Laboratory of Isotope Geochemistry, Guangzhou, P. R. of China

The high-resolution oxygen isotope record measured on conodonts from South China exhibits relative high values between 22 and $23 \%$ VSMOW during the glaciated Early Permian, translating into warm seawater temperature between 26 and $30^{\circ} \mathrm{C}$, assuming that the Late Palaeozoic ice volumes were comparable to the Pleistocene glacial maxima. In contrast to the earlier view that the Late Palaeozoic Ice Age terminated in the late Sakmarian, this record suggests waning of the ice sheets in the Kungurian. Ice melting is indicated by a decrease in $\delta^{18} \mathrm{O}$ of $2 \%$, which is interpreted as reflecting the combined effect of climatic warming and glacial ice melting. $4^{\circ} \mathrm{C}$ warming succeeded by 6 to $8^{\circ} \mathrm{C}$ cooling are observed during the Guadalupian-Lopingian transition, interpreted as combined climate changes induced by Emeishan volcanism and changes in habitat depth of 
gondolellid conodonts. Oxygen isotope values increase to $22 \%$ VSMOW in the Changhsingian, which suggests climate cooling and Clarkina moving to deeper waters due to the Changhsingian sea level rise. Across the P-Tr boundary, $\delta^{18} \mathrm{O}$ values decrease from 22 to $19 \%$, translating into warming of low latitudinal surface waters of $8^{\circ} \mathrm{C}$.

\title{
New discovery of Triassic radiolarians from Yarlung Zangbo Suture Zone in the Jinlu area, Zetang, southern Tibet [oral presentation]
}

\author{
Chen Dishu ${ }^{1} \&$ Luo Hui $^{1}$ \\ ${ }^{1}$ Chinese Academy of Sciences, Nanjing Institute of Geology and Palaeontology, Nanjing, P. R. of China; \\ E-mails:dschen@nigpas.ac.cnぬ builuo@nigpas.ac.cn
}

Well-preserved radiolarians have been extracted from eleven bedded chert samples collected near Jinlu Village, Zetang town, Southern Tibet. These bedded cherts may belong to the Mélange blocks of the Yarlung Zangbo Suture Zone. More than 14 genera were recognized preliminarily in the studied samples. They include Perisp, Cantalum, Betraccium, Sarla, Annulotriassocampe, Emiluvia, Praetrigonocyclia, Capnuchosphaera, Triassocyrtium, Canoptum, Cyptostephanidium, Astrocentrus, Aceniospongus, Weverella and so on. This radiolarian assemblage approximately indicates the MiddleLate Triassic in age. More detailed study on this radiolarian assemblage will give an exact age control for the chert block and that is very significant for the origin of the New Tethys Ocean in southern Tibet.

This study is supported by the "Strategic Priority Research Program (B)" of the Chinese Academy of Sciences, Grant No. XDB03010102.

\section{A coral-microbialite patch reef from the Late Carboniferous of Lang- ping, Guangxi, China [oral presentation]}

Chen Xiaohong ${ }^{1} \&$ Gong Enpu ${ }^{1}$

${ }^{1}$ Northeastern University, Department of Geology, Shenyang, P. R. of China; E-mail: chenxb000@163.com

A lower Pennsylvanian patch reef was found in Langping Country, Northwestern Guangxi, Southwestern China, on a carbonate platform margin setting. This buildup occurs within the Bashkirian Formation. The section of the patch reef shows three development stages, each stage is lenticular in shape. And the framework is built by a relatively low diversity assemblage of phacelloid rugose corals (mainly Diphyphyllum sp.) and microbialites (microbial crusts). The organisms adhering to the reef are echinoderms (crinoids), bivalves, solitary corals, gastropods, bryozoans, brachiopods, foraminifera, calcispheres, peloids, algae, calcimicrobes, ostracods. The syndepositional calcite cement filled in the frameworks may have an 
effect on the buildup. Microbialites played an important role in the formation of the reef-building framework. These frameworks are similar to some Triassic and Upper Jurassic coral-microbial reefs from the Tethys. According to the microfacies, the reef developed in a deeper and low energy environment.

\title{
Stable Sr isotopes, a new approach for Lower Cretaceous (Berriasian- Barremian) Boreal-Tethyan correlation [posterpresentation]
}

\author{
Wawrzyniec Chorazy ${ }^{1}$, Stéphane Bodin ${ }^{1} \&$ Jörg Mutterlose ${ }^{1}$ \\ ${ }^{1}$ Rubr University, Institute of Geology, Mineralogy and Geophysics, Bochum, Germany; \\ E-mail:wawryyniec.chorasy@rub.de
}

The interpretation of marine events requires precisely correlated biostratigraphic schemes. Only synchronous events can be interpreted in a global context. We present ${ }^{87} \mathrm{Sr} /{ }^{86} \mathrm{Sr}$-isotopy curves for the Berriasian to Barremian interval from belemnite rostra. These allow a stratigraphic correlation of the Boreal and Tethyan Realms independent of biostratigraphy and may help to overcome correlation problems caused by a distinct provincialism. The correlated Sr curves show two major discrepancies between the Boreal and the Tethyan biozonation schemes. The base of the Hauterivian in the Tethys, defined by the FO of A.radiatus, correlates in the Boreal Realm with the base of the E. noricum zone and not with the actual base of the Hauterivian defined by the E. amblygonium zone. The base of the Upper Barremian in the Boreal Realm, defined by the FO of P. elegans, correlates with the uppermost part of the Tethyan K. compressima zone in the Lower Barremian. In the Lower Barremian, the Boreal and the Tethyan $\delta^{18} \mathrm{O}$ values show a simultaneous excursion supporting the correlation based on the Sr-isotopes.

\section{Biostratigraphy of the terrestrial Permian-Triassic sequences in western Guizhou, South China [oral presentation]}

\author{
Chu Daoliang ${ }^{1}$, Tong Jinnan ${ }^{1}$, Yu Jianxin ${ }^{1}$, Shi Xiao ${ }^{1} \&$ Song Haijun ${ }^{1}$ \\ ${ }^{1}$ China University of Geosciences, State Key Laboratory of Biogeology and Environmental Geology, Wuhan, P. R. of \\ China; E-mail: cugchucbu@foxmail.com
}

The Permian-Triassic mass extinction was the greatest crisis of the Phanerozoic, which eliminated over $90 \%$ of the marine species and about $75 \%$ of the terrestrial species. Lots of studies have focused on the marine Permian-Triassic transitional records but very few on the terrestrial facies. Even the definition of the terrestrial Permian-Triassic boundary remains a controversy, and there are only a few studies dealing with the extinction pattern of some terrestrial taxa. A series of PermianTriassic transitional sections through the marine to terrestrial via paralic facies are well developed in the western Guizhou, South China, which provide unique 
opportunity for the understanding of the great transitional events and the definition of the boundaries in the different facies. This study will focus on the biostratigraphy of two terrestrial Permian-Triassic boundary sections in the western Guizhou, i.e. the Jiucaichong and Xiaohebian sections, based upon our recent discovery of fossil data.

14 conchostracan species, including three undetermined species in two genera, are identified in reference to their micro-sculptures under the SEM. Among them, seven species belong to Euestheria and the other seven species are Palaeolimnadia. Euestheria gutta occurs widespread in the Permian-Triassic boundary strata in Europe. Some Euestheria species have been found in the Lower Triassic Feixianguan Formation and Yongningzhen Formation in the western Guizhou. Palaeolimnadia also was reported from the Lower Triassic Liujiagou Formation and Qishan Formation in North China. These abundant conchostracan data also would be useful for understanding the evolution of terrestrial ecosystems during the great Permian-Triassic transition. These conchostracans are, of course, significant in the definition and correlation of the terrestrial Permian-Triassic boundary.

Fossil plants are relatively common in the terrestrial Permian-Triassic boundary strata at the studying sections. Two plant assemblages can be established. The Gigantonoclea guizhouensis-Annularia pingloensis assemblage from the Upper Xuanwei Formation, characteristic of the late Cathaysian Flora, is the last Permian assemblage in western Guizhou and eastern Yunnan. The Peltaspermum-relicts of the gigantopterids Assemblage from the top part of Xuanwei Formation and Kayitou Formation is composed of the relicts of the gigantopterid flora and Peltaspermum in the Early Triassic Induan.

Abundant sporopollens are found in the upper Xuanwei Formation and Lower Kayitou Formation. The sporopollen shows a change similar to the fossil plants across the Permian-Triassic boundary. The upper Xuanwei Formation is dominated by some typical Late Permian (Paleozoic types) pollens such as Yunnanospora, Verrucosisporites, Dictyophyllidites, Triquitrites, Calamospora, Polypodiidites and Laevigatosporites. The lower Kayitou Formation contains a few Late Permian forms similar to those from the upper Xuanwei Formation and some typical Early Triassic elements such as Aratrisporites and Lundbladispora.

According to the integrative appearance of conchostracan, plant and sporopollen fossils, the Permian-Triassic boundary in this region is roughly placed at the base of Kayitou Formation. But we suggest the conchostracans as the primary index fossils for the definition of the terrestrial Permian-Triassic boundary.

\section{Conchostracan fauna from the Kayitou Formation of western Guizhou, China [poster presentation]}

Chu Daoliang ${ }^{1}$, Tong Jinnan ${ }^{1}$, Yu Jianxin ${ }^{1}$, Shi Xiao ${ }^{1} \&$ Song Haijun ${ }^{1}$

${ }^{1}$ China University of Geosciences, State Key Laboratory of Biogeology and Environmental Geology, Wuhan, P. R. of China; E-mail: cugchucbu@foxmail.com 
A series of terrestrial Permian-Triassic boundary sequences are well exposed in the western Guizhou, South China. Recent studies show that there are diverse plant fossils and palynomorphs in the boundary strata of the western Guizhou. This study focuses on the conchostracan fossils from the Kayitou Formation across the Permian-Triassic boundary. Eleven conchostracan species and three undetermined species in two genera are identified in reference to their micro-sculptures under SEM. Among them, five species and two undetermined species belong to Euestheria, i.e. Euestheria gutta, E. orbicular, E. shizibaoensis, E. cf. yanjingxiensis, E. cf. dactylic, E. sp. 1, E.sp. 2, and six species and one undetermined species are Palaeolimnadia, i.e. Palaeolimnadia xuanweiensis, P.pusilla, P.globosa, P. contracta, P. komiana, P. shanxiensis, P. sp. 1. Some Euestheria species were found in the Lower Triassic Feixianguan Formation and Yongningzhen Formation of the western Guizhou. Palaeolimnadia were reported from the Lower Triassic Liujiagou Formation and Qishan Formation in North China. These abundant conchostracan data would be significant for the understanding of the evolution of terrestrial ecosystems during the Permian-Triassic transitional time, whereas, the conchostracans would be the key form to define the Permian-Triassic boundary in the terrestrial facies.

\title{
Spore-pollen assemblages show delayed terrestrial cooling in the aftermath of OAE 1a [oral presentation]
}

Jean Cors ${ }^{1}$, Ulrich Heimhofer ${ }^{1}$, Thierry Adatte $^{2}$, Peter A. Hochuli ${ }^{3}$, Stefan Huck $^{1} \&$ Telm Bover-Arnal ${ }^{4}$

\author{
'Leibniz. University, Institute for Geology, Hannover, Germany; \\ E-mail:cors@geowi.uni-hannover.de \\ ${ }^{2}$ University of Lausanne, Institute of Earth Sciences, Lausanne, Switzerland \\ ${ }^{3}$ University of Zurich, Palaeontological Institute and Museum, Zurich, Switzerland \\ ${ }^{4}$ Universitat de Barcelona, Facultat de Geologia, Departament de Geoquímica, Petrologia i Prospecció Geòlogica, \\ Barcelona, Spain
}

Early Aptian palynomorph-bearing deposits from the Forcall Formation, Maestrat basin (Spain), have been investigated using bulk rock geochemistry (TOC, $\mathrm{CaCO}_{3}$, $\left.\delta^{13} \mathrm{C}_{\text {carb }}\right)$ as well as palynofacies analysis and palynology. The carbon-isotope trend enables detailed correlation with established data covering OAE $1 \mathrm{a}$. A total of 28 different genera of spores and pollen have been distinguished within the studied 38 samples. Non-saccate gymnosperm pollen record a major shift during and in the aftermath of OAE 1a. Classopollis pollen show a two-step decrease from being the dominant pollen group to abundances as low as $21 \%$ during the OAE 1a, followed by a recovery to pre-OAE values shortly thereafter. The abundances of Araucariacites and Inaperturopollenites pollen show an opposing trend compared to Classopollis, interpreted to indicating a cooling episode. The climax of this cooling 
episode was significantly delayed in comparison to the end of organic carbon-rich deposition in the marine realm.

\section{The Xiaheyan entomofauna (Namurian, Late Carboniferous; Ningxia, China): discoveries and perspectives [oral presentation]}

Cui Yingying ${ }^{1,2}$, Olivier Béthoux ${ }^{3}$, Gu Junjie ${ }^{4}$, Jakub Prokop ${ }^{5}$, Jörg W. Schneider $^{2} \&$ Ren Dong $^{1}$

${ }^{1}$ Capital Normal University, Key Laboratory of Insect Evolution and Environmental Changes, Beijing, P. R. of China; E-mails: cuiying19860105@gmail.com \& rendong@mail.cnu.edu.cn

${ }^{2}$ Technical University Bergakademie Freiberg, Institute of Geology, Department of Palaeontology, Freiberg/Sa., Germany; E-mail:Joerg.Schneider@geo.tu-freiberg.de

${ }_{3}^{3}$ Muséum National d'Histoire Naturelle, UMR 7207 CNRS (CR2P),Paris, France; E-mail: obethoux@mnbn.fr

${ }^{4}$ North University of Nationalities, College of Biological Science and Engineering, Yinchuan, P. R. of China;

E-mail:orthoptera_gu@yahoo.cn

${ }^{5}$ Charles University Prague, Faculty of Science, Department of Zoology, Prague, Czech Republic;

E-mail:jprokop@natur.cuni.cz.

The description of the Xiaheyan Pennsylvanian insect fauna (Tupo Formation, Namurian B-C; Xiaheyan Village, Zhongwei City, Ningxia, China) is an ongoing project. This locality is exceptional in the abundance of available material, allowing intra-specific variability to be better assessed in several distinct groups. Up to now, 20 species have been described. Typical Late Carboniferous groups are represented, viz. Archaeorthoptera (i.e. stem-Orthoptera), stem-Dictyoptera, Palaeodictyopteroida (including Megasecoptera), and Grylloblattida, as well as some groups expected to occur in the Late Carboniferous, viz. Plecoptera. Representatives of several other major groups remain to be described. Although more detailed sampling is necessary (and will be conducted in the coming years), the documentation at hand pictures a very diverse fauna, with groups phylogenetically distant, corroborating the view that insects already experienced a long evolutionary history prior to this period. Detailed abundance analyses will be conducted in the next years to allow this entomofauna to be meaningfully compared to other Late Carboniferous ones.

\section{New insights into the histology of the vertebral centra of basal tetrapods [posterpresentation]}

Marylène Danto $^{1}$ \& Florian Witzmann ${ }^{1}$

${ }^{1}$ Museum für Naturkunde, Leibniz Institute for Research on Evolution and Biodiversity, Berlin, Germany;

E-mails: marylene.danto@mfn-berlin.de_florian.witzmann@mfn-berlin.de 
Paleohistological studies of long bones have provided more and more insight into the life history and mode of life of a great number of extinct tetrapods in the past years. However, little is known about the histology of the vertebral centrum. In this study, the histology of vertebral centra of Palaeozoic and Mesozoic basal tetrapods is examined. Metoposaurus sp. is a temnospondyl with a disc-shaped intercentrum. Its microstructure is characterized by an unorganized trabecular network with parallel fibered bone and high vascularization. Another temnospondyl, Plagiosaurus depressus, has a cylindrical vertebra. It is composed of well-arranged compact bone and a dense trabecular system. Calcified cartilage is found e.g. on the endplates. A crescent-shaped intercentrum of the temnospondyl Cyclotosaurus sp. is characterized by dense Haversian tissue. An unidentified lepospondyl microsaur has a holospondylous, cylindrical vertebral centra. The microstructure shows compact bone and is distinctly marked by the notochordal canal. Ongoing analysis of additional taxa will provide further insight into vertebral ossification patterns in basal tetrapods.

\title{
The earliest appearance of pearls in the paleontological record: clues for complex parasite life cycles or fossil biases ? [oral presentation]
}

\author{
Kenneth De Baets ${ }^{1}$, Aleksandra Skawina ${ }^{2}$ \& Christian Klug ${ }^{3}$ \\ ${ }^{1}$ Friedrich-Alexander University Erlangen-Nürnberg, Geo-Center of Northern Bavaria, Section Palaeoenvironmental \\ Research, Erlangen, Germany; E-mail: kenneth.debaets@fau.de \\ ${ }^{2}$ University of Warsaw, Faculty of Biology, Department of Animal Physiology, Warsaw, Poland; \\ E-mail:askawina@biol.uw.edu.pl \\ ${ }^{3}$ University of Zurich, Paleontological Institute and Museum, Zurich, Switzerland; \\ E-mail:chklug@pim.u₹h.ch
}

Recent molecular studies have suggested that the basal parasitic flatworms had a simple life cycle, while more derived parasitic flatworms developed complex life cycles. The intermediate stages of the latter have often been implicated in the formation of bivalve pearls. Pearls in fossil mollusks have therefore often been used as an indication for the presence of complex parasite life cycles. We investigated the occurrence of pearls and flatworm fossils through geological time in an up to date ecological and phylogenetic framework. Their fossil record proves to be extremely biased. Furthermore, the occurrence of pearls in distantly related orders as well as various other mollusk phyla suggests an ancient origin of pearl-like structures in the earliest shelled mollusks. Although the flatworm body fossil record is very poor, it does agree with the idea that these parasites coevolved with their invertebrate hosts. Nevertheless, the use of the host fossil record to test the hypothesis of coevolution leads to circularity (in absence of reliable parasite fossils), which might be resolved by calibrating parasite molecular clocks with biogeographic events instead. 


\title{
A new species of Cupressaceae (sensu lato) from the Lower Cretaceous of northeastern China and its pollen tube [oral presentation]
}

\author{
Dong Chong ${ }^{1}$, Sun Bainian ${ }^{1}$, Xu Xiaohui ${ }^{1} \&$ Yang $\mathrm{Yi}^{1}$ \\ ${ }^{1}$ Lanzhou University, School of Earth Sciences, Key Laboratory of Mineral Resources in Western China (Gansu \\ Province), Lanzhou, P. R. of China; E-mail:dongzhong2009@lzu.cn
}

A new conifer, from the Lower Cretaceous of western Liaoning, Northeastern China, is described and proposed as a new species of Cupressaceae $s . l$. The new material consists of impressions represented by well-preserved leafy twigs and branches as well as ovulate and pollen cones. Leafy shoots with at least two orders of branching, ultimate branches alternate with helically arranged leaves, linear oblong, decurrent and narrowly twisted at base, with serrulate margins and rounded apex; flattened dorsoventrally, with thin and slightly visible veins. Epidermal cells mostly are rectangular with slightly unducate anticlinal walls or polygonal. Ovuliferous cones elliptical, less than $1 \mathrm{~cm}$ long, borne terminally on ultimate and penultimate shoots, composed of spirally arranged bracts with ovuliferous scales disposed on their adaxial surface. Bracts are intimately fused with and more massive than the ovuliferous scale and composed of a stalk-like basal portion and an expanded flattened head with an acute apex. Each ovule cone contains more than 18 such bract-scale complexes, and each ovuliferous scale produced 2 seeds. Each seed is small (less than $1 \mathrm{~mm}$ in length and $0.5 \mathrm{~mm}$ in width), wingless, ovate to elongated ovate, and has a pointed micropyle. Pollen cones are born terminally on ultimate and penultimate branches. Leaves distal to the pollen cone-bearing axes are notably modified in shape and size relative to ordinary leaves, and a transition zone is observed along the foliar spiral. Pollen cones are elliptical. The microsporophylls occur in a minimum number of 7 ; they are spirally arranged on the axis and emerge at right angles. Each microsporophyll is composed of a thin basal stalk and an expanded distal head. This characteristic combination indicates that this fossil is placed within the basal Cupressaceae (i.e. the former "Taxodiaceae"). Compared with the modern and fossil members of the former Taxodiaceae in morphology and structure of leafy twigs, pollen cones and ovule cones, the new material shares some consistent features with the extant Taiwania and Cunninghamia and the fossil genera Elatides and Sewardiodendron, but differs from them in other aspects to be included in these published genera. The present fossil is very similar to Austrobamia minuta from the Jurassic of Chubut province, Argentina; however, it is different with the South America material in number of cone scales per ovule cone, number of seeds per ovuliferous scale, and in details of pollen cones.

Fortunately, after maceration with Schulze's solution, the pollination mechanism of the present conifer fossil is observed under LM and SEM, as a number of fossil pollen tubes as well as archegonia are discovered from the fossil ovuliferous scale. This is the first record of a conifer pollen tube and archegonia from the Mesozoic. Archegonia are globose to elliptical, $50-70 \mu \mathrm{m}$ in diameter, with one or 
two circulars. Pollen tubes are long and spiral, about 3-5 $\mu \mathrm{m}$ in diameter, with many tumour protuberances on the extine. In conifers, pollen tubes deliver the male gametes (sperm) into the egg cells, and in the process, interact with the nucellar cells of the ovule and the archegonia of the female gametophyte. The pollen tubes of conifers represent an intermediate form between the haustorial pollen tubes of cycads and Ginkgo and the organizationally simplified and faster growing pollen tubes of flowering plants. The discovery of the pollen tube and associated archegonia from the conifer fossil from the Lower Cretaceous of Northeastern China not only offers insight into a more primitive form of sexual reproduction, but also expands our understanding of this important stage in the reproductive process of conifers and seed plants in general. Meanwhile, the fossil pollination mechanism provides us the evidence to realize the ancestral mechanism of early conifers.

This work was conducted under the 973 Program of China (No. 2012CB822003); NSFC (No. 41172022), and Specialized Research Fund for the Doctoral Program of Higher Education (Grant No. 20120211110022).

\title{
Taxonomic revisions of Anurans from the Lower Cretaceous Jehol Group of western Liaoning, China [posterpresentation]
}

\author{
Dong Liping ${ }^{1}$, Zbyněk Roček ${ }^{2}$, Wang Yuan ${ }^{1} \&$ Marc E. H. Jones ${ }^{3}$ \\ ${ }^{1}$ Chinese Academy of Sciences, Institute of Vertebrate Paleontology and Paleoanthropology, Key Laboratory of \\ Vertebrate Evolution and Human Origins, Beijing, P. R. of China; E-mail: marie.donglp@gmail.com \\ ${ }^{2}$ Academy of Sciences of the Czech Republic, Institute of Geology, Department of Palaeobiology, Prague, Czech \\ Republic \\ ${ }^{3}$ University College London, Research Department of Cell and Developmental Biology, London, U.K.
}

To date, the Lower Cretaceous Jehol Group of western Liaoning, China has yielded five monotypic genera of anurans, i.e., Liaobatrachus grabaui Ji \& Ji, 1998 and Callobatrachus sanyanensis Wang \& Gao, 1999 (both from the Sihetun Loc., Beipiao; lower part of Yixian Fm.), Mesophryne beipiaoensis Gao \& Wang, 2001 (Heitizigou Loc., Beipiao; lower part of Yixian Fm.), Dalianbatrachus mengi Gao \& Liu, 2004 (Huangbanjigou Loc., Beipiao; lower part of Yixian Fm.), and Yizhoubatrachus macilentus Gao \& Chen, 2004 (Hejiaxin Loc., Yixian; middle part of Yixian Fm.), which were all established on a single specimen. However, the validity of these taxa has been questioned due to lack of materials and poor preservation of the holotype in some taxa (e.g., Liaobatrachus grabaui).

We herein provide a comprehensive analysis of the Jehol frogs that includes a re-examination of the published taxa as well as new observations on a few dozen new specimens collected over the past 10 years. The results show that the five previously named taxa can be referred to three species of Liaobatrachus, i.e., L. grabaui, L. beipiaoensis comb. nov. and L. macilentus comb. nov. The diagnosis of Liaobatrachus is revised, and a new diagnosis is provided for each species of this genus. 
Liaobatrachus is a Cretaceous anuran of medium body size which presents the following unique combination of characteristics: dermal roofing bones unsculptured; maxilla deep and bifurcated anteriorly; nasals with extensive midline contact; a large fontanelle between paired frontoparietals; squamosal with short zygomatic ramus that does not contact maxilla; vomer with dentigerous portion bearing 6-10 teeth arranged in single row and long postchoanal process which forms narrow angle with prechoanal process; parahyoid V-shaped; nine amphicoelous presacrals; atlas with type II cotyles; three pairs of recognizable ribs on presacrals II-IV; sacral diapophyses broadly dilated and fan-like with convex lateral edges; sacro-urostylar articulation monocondylar; urostyle with one pair of transverse processes; scapula short and discoglossid-like whose anterior margin is straight and whose anteromedial margin is overlapped by distal end of clavicle; cleithrum not bifurcated medially; ilium with no dorsal protuberance or dorsal crest.

We also establish Liaobatrachus zhaoi sp. nov., on the basis of a dozen threedimensionally well-preserved specimens from a new locality in Beipiao of Liaoning. This taxon is distinguished from other species of Liaobatrachus by having relatively long hind limbs, a rounded rather than triangular acetabulum, and a gradually-tapering cultriform process of the parasphenoid.

Comparisons with other Mesozoic and extant anurans and the primary phylogenetic analysis both suggest that Liaobatrachus is a member of the anuran crowngroup and forms a polytomy with leiopelmatids (Ascaphus and Leiopelma) and the remaining crown-group anurans (Lalagobatrachia).

In addition, an unnamed frog from a higher horizon has narrow sacral diapophyses and particularly long legs. It is clearly different from Liaobatrachus and represents another form of anuran in the Jehol Biota, and needs further investigation.

\title{
Middle and late Cambrian trilobite communities of the Fenghuang western Hunan, China [posterpresentation]
}

\author{
Duan $\mathrm{Ye}^{1}$ \\ 1 Shenyang Normal University, College of Paleontology, Shenyang, P. R. of China; \\ E-mail:duanye3731@hotmail.com
}

Middle and Late Cambrian trilobite faunas are described from the Dama section in western Hunan. There, trilobites are the most common macrofossils and include a mixture of cosmopolitan agnostoids and polymeroids. Most of the fossils are well preserved in dark grey or gray granular, laminated, argillaceous carbonates. The trilobite faunas are assigned to 63 genera and subgenera, 84 species, and two forms of gen. et sp. indet. Three new species were described by the present author in 2004. They are Hardyoides damaensis, Meringaspis damaensis and Rhyssometopus (Rodtrifinis) nitidus. In addition, Erixanium is recognised for the first time in the study area. 
The discovery of this genus is significant for biostratigraphical correlation of the Late Cambrian in the Australo-Asia region.

According to the vertical distribution regularity, Middle and Late Cambrian trilobites can be divided into 9 trilobite communities for the Dama section. The section comprises rich trilobites in the study area. Its ecological features reflect the evolution of the palaeoenvironments in the area.

Based on the analysis of trilobite communities, the present author concludes that from the east Mt. Lailong to Dama through Fenghuang, further east, until Chenxi (close to central Hunan), palaeoenvironments changed from an oxygenrich shallow-water (platform margin slope) into an oxygen-poor deep-water setting (basin).

Geobiology of a carbonate system with Ediacara-type organisms: The Shibantan Member (Dengying Formation, South China) [oral presentation]

Jan-Peter Duda ${ }^{1}$, Martin Blumenberg', Volker Thiel ${ }^{1}$, Klaus Simon ${ }^{2}$, Zhu Maoyan $^{3}$, Walter Riegel ${ }^{1} \&$ Joachim Reitner ${ }^{1}$

${ }^{1}$ Georg-August University Göttingen, Geoscience Centre, Department of Geobiology, Göttingen, Germany;

E-mail:jduda@gwdg.de

${ }^{2}$ Georg-August University Göttingen, Geoscience Centre, Department of Geochemistry, Göttingen, Germany

${ }^{3}$ Chinese Academy of Sciences, Nanjing Institute of Geology and Palaeontology, State Key Laboratory of Palaeobiology and Stratigraphy, Nanjing, P. R. of China

Findings of Ediacara-type organisms are usually restricted to siliciclastic environments. One rare exception is the Shibantan Member, which comprises organic-rich limestones, and we here present new data on the geobiology of this ecosystem. Sedimentary facies and organic walled fossils reveal the presence of autochthonous microbial mats, and horizontal traces of putative bilateralians are commonly associated with these microbial mats. $\delta^{13} \mathrm{C}$ values of carbonates and organic matter hint at the presence of primary producers and sulfate reducers. Importance of the latter is further evidenced by the presence of sulfurized biomarkers, indicating high amounts of $\mathrm{H}_{2} \mathrm{~S}$ during earliest diagenesis. Sedimentary facies and trace element distributions suggest a temporary stratified water body, frequently ventilated by storm events. Most likely, Ediacara-type organisms and vendotaenids thrived in this dynamic environment whenever conditions were favorable. Our data indicate that widespread suboxia prevailed during the evolution of complex life in Ediacara ecosystems. 


\title{
Mutable collagenous tissue in Traumatocrinus stems? - Evidence from 3D reconstruction [oralpresentation]
}

\author{
Janina F. Dynowski ${ }^{1,4}$, Hans Hagdorn ${ }^{2}$, Christian Tötzke ${ }^{3}$, James H. Nebelsick ${ }^{4}$ \\ \& Anita Roth-Nebelsick ${ }^{1}$
}

\author{
1 Stuttgart State Museum of Natural History, Stuttgart, Germany; \\ E-mails:janina.dynowski@smns-bw.de@ anita.rothnebelsick@smns-bw.de \\ 2Muschelkalkmuseum,Ingelfingen, Germany; E-mail:encrinus@hagdorn-ingelfingen.de \\ ${ }^{3}$ Helmboltz-Zentrum Berlin für Materialien und Energie GmbH, Berlin, Germany; \\ E-mail:christian.toetzke@helmboltz-berlin.de \\ ${ }^{4}$ Eberbard-Karls University of Tübingen, Department of Geosciences, Tübingen, Germany; \\ E-mail:nebelsick@uni-tuebingen.de
}

The crinoid Traumatocrinus (order Encrinida) is commonly found attached to driftwood logs in the Triassic black shale Xiaowa Formation of South China. Unlike the driftwood dwelling Jurassic Seirocrinus and Pentacrinites (order Isocrinida) and other stalked crinoids, its stem shows a very peculiar network of interconnected canals. Additionally to the longitudinal central canal, the Traumatocrinus stem contained a set of multiple parallel canals (tubuli). These were connected to the stem surface by serially arranged short canals (fossulae) protruding perpendicularly from the tubuli along the intercolumnar facets. For a 3D reconstruction of this complex canal system, MicroCT scans were obtained from several stem fragments, including proximal, middle and distal pluricolumnals. The canals may have contained mutable collagenous tissue which enabled Traumatocrinus to actively stiffen and unstiffen its stem, resulting in the ability to move it as a reaction to changes in flow conditions. The tubuli bunches may also have prevented torsion of the stems, which reached more than $10 \mathrm{~m}$ length.

\section{Microfacies and Devonian reef development in the Qued Cherrat Zone, Moroccan Meseta [oral presentation]}

\author{
Stephan Eichholt ${ }^{1} \&$ R. Thomas Becker ${ }^{1}$ \\ ${ }^{1}$ Westfälische Wilhelms-Universität Münster, Institut für Geologie und Paläontologie, Münster, Germany; \\ E-mails:s_eich01@uni-muenster.de_orbecker@uni-muenster.de
}

Givetian reef limestones occur widely in the Moroccan Meseta, for example in the $\mathrm{N}-\mathrm{S}$ running, narrow Oued Cherrat Zone S of Rabat.

The Ain Khira South section in the N consists of a back reef setting with characteristic lagoonal facies types. At the base there are peloidal grainstones with fragments of brachiopods intercalated with detrital stromatoporoid floatstones. Associated are Stachyodes-Thamnopora floatstones and bulbous stromatoporoidStachyodes boundstones. Bioclastic mud-/wackestones indicate more restricted realms within the lagoon. Limestone beds with Stringocephalus are intercalated. At 
the top of the section, Amphipora Bafflestones give further evidence for a persisting lagoonal setting.

The Ain-as-Seffah section in the S represents a big, partially slumped mass. It consists of a small bioherm/patch reef that developed on a distal, deeper neritic carbonate platform. The base consists of peloidal crinoid grainstone with reefal detritus. Above, typical facies types are coral (Thamnopora, Alveolites, Phillipsastrea) rud-/boundstones. The consistent presence of neritic conodont faunas proves permanent open marine conditions. Overlying brachiopod floatstones suggest an extinction of the reef by basal Frasnian drowning (Frasnes Event).

\section{The Cambrian Ecological Innovation: what biota of the Medi- terranean Gondwana tell us about early Phanerozoic ecosystems} [oral presentation]

Olaf Elicki ${ }^{1}$, Gabriela Mángano ${ }^{2}$, Richard Hofmann ${ }^{3}$ \& Muftah Mahmud Altumi ${ }^{4}$

1Technical University Bergakademie Freiberg, Institute of Geology, Department of Palaeontology, Freiberg/Sa., Germany; E-mail: elicki@geo.tu-freiberg.de

${ }^{2}$ University of Saskatchewan, Department of Geological Sciences, Saskatoon, Saskatchewan, Canada;

E-mail: gabriela.mangano@nsak.ca

${ }^{3}$ University of Zurich, Paleontological Institute and Museum, Zurich, Switzerland;

E-mail: richard.hofmann@pim.ugh.ch

4Libyan Petroleum Institue, Tripoli, Libya; E-mail: muftab551@yahoo.de

Discovery of many new faunas and large re-investigation during last years led to significant increase not only in the knowledge on Cambrian palaeobiology, stratigraphy and palaeobiogeography, but also in our understanding of ecological relations and structures, and of the complexity of resulting ecosystems. The European Shelf of Gondwana bears a lot of types of biotic communities, indicating a surprising large degree of ecological differentiation typical for shallow-marine and marginal-marine environments with a lot of prospective and fundamental ecological niches. Especially, marine-to-terrestrial transitional regions of the early Cambrian show ecological architectures much more evolved than hitherto assumed. It is further supposed that also terrestrial areas have been already occupied in various extent. The remarkable radiation of biota near the beginning of the Cambrian was not restricted to the fully-marine realm.

The here-called Cambrian Ecological Innovation encompasses not only fully marine habitats, but also marginal-marine and terrestrial systems and represents a separate, important and outstanding aspect of the Cambrian Explosion. 


\section{A revision of Eocene Antarctic fishes (Vertebrata: Neopterygii: Teleostei) [oral presentation]}

Andrea Engelbrecht ${ }^{1}$, Jürgen Kriwet $^{1}$, Thomas Mörs ${ }^{2}$, Cathrin Schwarz ${ }^{1}$, Marcelo Reguero ${ }^{3} \&$ Claudia Tambussi $^{3}$

${ }^{1}$ University of Vienna, Department of Palaeontology, Vienna, Austria; E-mails: andrea.engelbrecht@univie.ac.at; juergen.kriwet@univie.ac.atecathrin.schwar:@univie.ac.at

${ }^{2}$ Swedish Museum of Natural History, Department of Palaeobiology, Stockholm, Sweden;

E-mail: thomas.moers@nrm.se

${ }^{3}$ Museo de La Plata, División Paleontología de Vertebrados, La Plata, Argentina;

E-mail: regui@fcnym.unlp.edu.ar

Living Antarctic ice-fishes (Notothenioidei) are unique among teleosts because they developed structures (e.g., antifreeze glycoproteins in blood) to survive subzero temperatures in the Southern Ocean. They dominate today's Antarctic fish fauna, which is striking in its low taxonomic diversity and high endemism patterns.

In the Eocene, the well-known Antarctic fish fauna was diverse and cosmopolitan and differs considerably from today's Southern Ocean fish faunas. The origin and evolution of ice-fishes are still disputed despite few putative fossil records from the Eocene of Seymour Island, where remains of diverse fish assemblages are very common.

Here, we present a revision of all known Eocene Antarctic teleostean skeletal remains focusing on jaw elements and newly discovered otoliths. Selected extant ice-fishes and cods are compared morphologically, by using micro-CT techniques for $3 \mathrm{D}$ visualization of skeletal structures and otoliths. According to our results, all examined fish remains from Seymour Island, including those previously assigned to notothenioids, display character combinations distinctive for gadiforms but not for ice-fishes.

\section{Permian bryozoan fauna from the Zhongba area of Xizang, Tibet [posterpresentation]}

Andrej Ernst ${ }^{1}$

${ }^{1}$ Christian-Albrechts-Universität, Institut für Geowissenschaften, Kiel, Germany; E-mail: ae@gpi.uni-kiel.de

Permian bryozoan fauna has been reordered from the Zhongba Formation of Zhongba area of Xizang, Tibet. The Zhongba Formation comprises pale purple, reddish thickened and massive, fossil-rich calcareous dolomites and limestones. The rocks of the Zhongba Formation contain, besides bryozoans, brachiopods, solitary corals, and crinoids. The identified bryozoans include more than 20 species: Fistuliramus sp., Liguloclema cf. meridiana (Etheridge, 1926), Goniocladia sp., Sulcoretepora sp., Fistulipora spp., Eridopora sp., Ulrichotrypella omanica Ernst et al., 2008, Dyscritella sp., Rhabdomeson spp., Streblotrypa (Streblotrypa) binodata Ernst et al., 
2008, Streblotrypa (Streblascopora) elegans Sakagami, 1961, Streblotrypa (Streblascopora) sp., Primorella sp., Timanotrypa sp., Mackinneylla sp., Spinofenestella sp., Polypora spp., Protoretepora sp. This bryozoan association suggests a Lower to Middle Permian age of the Zhongba Formation, and displays palaeobiogeographic relations to Australia, Oman, Thailand and Urals.

\title{
Seasonal bioerosion patterns along a bathymetrical transect in the Ionian Sea, Eastern Mediterranean [oral presentation]
}

Claudia Färber ${ }^{1,2}$, Max Wisshak ${ }^{1}$, Nikoleta Bellou ${ }^{3}$, Ines Pyko ${ }^{4}$ \& André Freiwald $^{1,2}$

\author{
1 Senckenberg am Meer, Marine Research Department, Wilhelmshaven, Germany; \\ E-mails: claudia.faerber@senckenberg.de; max.wisshak@senckenberg.de_o andre.freiwald@senckenberg.de \\ ${ }^{2}$ University of Bremen, MARUM - Center for Marine Environmental Sciences and Faculty of Geosciences, Bremen, \\ Germany \\ 3Institute of Oceanography, Hellenic Centre for Marine Research (HCMR), Attica, Greece; E-mail: bellou@hcmr.gr \\ ${ }^{4}$ Friedrich-Alexander University Erlangen-Nürnberg, Geo-Center of Northern Bavaria, Erlangen, Germany
}

In the scope of a one year experiment off the W-Peloponnese Peninsula (Greece), the influence of (1) seasonality, (2) bathymetry, and (3) orientation on bioerosion rates and ichnodiversity were investigated. Twelve platforms equipped with experimental substrates on the bottom and top side were deployed in 15, 50, 100, and $250 \mathrm{~m}$ water depth. Preliminary results after $1 / 2$ year of exposure comprise the record of eleven ichnotaxa, whereby traces of cyanobacteria and green-algae did dominate in 15 and $50 \mathrm{~m}$ depth, while towards deeper waters only fungal traces were observed. The comparison of the summer (Feb-Oct) and winter months (Oct-Apr) indicate a strong seasonal influence on bioerosion and carbonate accretion rates with fourfold higher values for the summer half year. Along the transect, highest bioerosion and carbonate accretion rates were observed on the top side in $15 \mathrm{~m}$ and on the bottom side in $50 \mathrm{~m}$ water depth, respectively. With increasing depth, both rates strongly decrease. The longitudinal comparison to a previous experiment at the Azores Archipelago (Atlantic Ocean) yields marked similarities in the bathymetrical distribution of bioerosion processes.

\section{Whale ears inside and out: are low-frequency hearing and cranial shape related in early baleen whales (Cetacea, Mysticeti)? [poster presentation]}

Julia M. Fahlke ${ }^{1}$, Indira Ritsche ${ }^{1} \&$ Oliver Hampe $^{1}$

${ }^{1}$ Museum für Naturkunde, Leibniz Institute for Research on Evolution and Biodiversity, Berlin, Germany;

E-mails:julia.fablke@mfn-berlin.de; indira.ritsche@mfn-berlin.de@o oliver.hampe@mfn-berlin.de 
Whales evolved from terrestrial artiodactyls. Toothed and baleen whales (Odontoceti and Mysticeti) originated from archaeocetes at the Eocene/Oligocene boundary. High-frequency hearing in Odontoceti is rather well-understood today. However, the physiology and timing of low-frequency hearing in Mysticeti remain unresolved. Cranial asymmetry is known in Odontoceti and archaeocetes, but not in Mysticeti.

The objectives of our ongoing study are (1) to identify morphological changes of the inner ear related to low-frequency hearing in Mysticeti, (2) to determine when low-frequency hearing evolved, and (3) to test whether mysticete cranial symmetry is secondary and related to low-frequency hearing.

For this purpose, the periotic complex of extant and extinct Mysticeti is analyzed using computed tomography (CT). Biometric data of the cochlea that are indicative of low frequencies are compared. Cranial shape of archaeocetes and Mysticeti is analyzed applying three-dimensional geometric morphometrics to surface models generated from CT scans or with the help of photogrammetry. Additionally, the internal anatomy of selected skulls is studied from CT data.

\title{
Correlation between sedimentology and the preservation of dinosaur tracks at the Early Cretaceous Dinosaur Tracksite in Münchehagen (Lower Saxony, Germany) [poster presentation]
}

\author{
Daniel Falk ${ }^{1}$ \& Oliver Wings ${ }^{2,3}$ \\ ${ }^{1}$ Technische Universität Bergakademie Freiberg, Geologisches Institut, Freiberg/Sa., Germany; \\ E-mail:daniel.falk.email@gmail.com \\ ${ }^{2}$ Niedersächsisches Landesmuseum Hannover, Hannover, Germany; E-mail: dr.wings@gmail.com \\ ${ }^{3}$ Museum für Naturkunde, Berlin, Germany
}

Münchehagen is well-known for its abundance of Berriasian dinosaur trackways. Additional tridactyl iguanodontid and theropod trackways were discovered in the 'Wesling-Quarry' adjacent to the Dinosaurier-Park in 2004 and subsequently excavated during the past years. A geological profile investigates the connection between sedimentology and track preservation. True tracks are embedded in mud- to siltstone layers, interpreted as slack water deposits. Undertracks are preserved in fine grained and strongly siliceously cemented quartz sandstones, indicating higher flow regimes. The beds show ripple marks, dissolution cracks/sutures, and bioturbation by invertebrates and dinosaurs. Some bedding planes have drainage structures, rough jagged surfaces, and/or are partially covered with coaly layers. Inhomogenously embedded coaly particles from plant detritus are very common. Small $(1-3 \mathrm{~cm})$ oval impressions are interpreted as shell imprints. 


\title{
Cambrian Lagerstätten in the Barrandian area (Czech Republic) [oral presentation]
}

\author{
Oldřich Fatka ${ }^{1}$, Lukáš Laibl ${ }^{1} \&$ Martina Nohejlová ${ }^{1}$ \\ ${ }^{1}$ Charles University, Faculty of Science, Institute of Geology and Palaeontology, Prague, Czech Republic; \\ E-mail:fatka@natur.cuni.cz.
}

Cambrian successions of the Barrandian area are well known by the common skeletal fauna studied for more than 150 years. Despite such a long tradition of palaeontological research and the high level of recent knowledge, exceptionally preserved remains were obviously underestimated. In the last ten years, softbodied fossils (= from Konservat Lagerstätten) have been discovered in several stratigraphical levels, namely in the early Cambrian Paseky Shale Member (Cambrian Series 2) and in the Jince and Buchava formations (both Cambrian Stage 5).

Typical Burgess Shale-type of preservation (e.g. Wiwaxia, Hurdia, Eldonia, articulated lobopodians) as well as preservation of soft tissue has been established in spectacular arthropods as well as in several trilobites. The collections also contain exceptionally numerous ontogenetic stages of trilobites (e.g. Sao, Ellipsocephalus, Paradoxides s.l.) and echinoderms (eocrinoid genus Akadocrinus, edrioasteroid genus Stromatocystites), examples of "frozen behaviour" (e.g. mortichnia, cryptic behaviour, feeding of agnostids, trilobites and hyoliths on carcasses of both skeletal and softbodied fauna) and malformed agnostids and diverse trilobites.

\section{Using Finite Element Analysis for reconstructing soft-tissues in ornithischian dinosaurs [oral presentation]}

\author{
Regina Fechner ${ }^{1}$, Julian Falkenstein ${ }^{1}$, Nina Sverdlova ${ }^{1}$ \& Rainer Gößling ${ }^{1}$ \\ ${ }^{1}$ Rubr-Universität Bochum, Fakultät für Maschinenbau, 'Biomechanics Research Group', Bochum, Germany; \\ E-mails:fecbner@lmk.rub.de; julian.falkenstein@lmk.rub.de; sverdlova@lmk.rub.de@ goessling@lmk.rub.de
}

Reconstructing soft-tissues based on phylogenetic inference considerably reduces the degree of speculation and generates reliable results in extinct archosaurs. Nonetheless, soft-tissue reconstructions based on phylogenetic inference alone tend to be very conservative and hence it has been argued to apply an extrapolatory approach for investigating functional adaptations.

We present here the reconstruction of the soft-tissues attached to the pelvis of the basal ornithischian dinosaur Lesothosaurus diagnosticus using a combination of phylogenetic and functional inference. For the phylogenetic inference of the softtissues attached to the pelvis of Lesothosaurus, the extant phylogenetic bracket approach was applied. For the functional inference, FE analysis was used as a tool for simulating stress pattern imposed on the pelvis by the applied loads. Our findings are: (i) the FE models based solely on phylogenetic inference show 
bending loads and stress peaks with values ranging in a non-physiological loading; (ii) the combination of phylogenetic inference and functional inference produce a FE model loaded in a physiological range.

\title{
Finite Element Methods as a means for the mechanical analysis of the crocodilian pelvis [posterpresentation]
}

\author{
Regina Fechner ${ }^{1} \&$ Daniela Schwarz-Wings ${ }^{2}$ \\ 'Rubr-Universität Bochum, Fakultät für Maschinenbau, 'Biomechanics Research Group', Bochum, Germany; \\ E-mail:fechner@lmk.rub.de \\ ${ }^{2}$ Museum für Naturkunde, Leibniz-Institut für Evolutions- und Biodiversitätsforschung, Berlin, Germany; \\ E-mail:d.scbwarz.wings@mfn-berlin.de
}

Studies on the mechanical loading of the pelvis of extant archosaurs provide a functional explanation for the form (shape and structure) and orientation of the pelvic bones. A method that allows for investigating the relationship between mechanical loading and form and orientation of bones is the finite element $(\mathrm{FE})$ method. In the study presented here, FE analysis and FE synthesis are applied to provide new insights into the mechanical loading of the pelvis of extant crocodiles. In extant crocodiles, limb muscles, axial muscles and abdominal muscles attach to the pelvis. The function of the muscles attached to the crocodylian pelvis comprise locomotion, ventilation and trunk stabilisation. Changes in one of these functions has an impact on the mechanical loading of the pelvic bones and hence on it's form. Our findings indicate that especially the orientation of the pubis and ischium is highly influenced by the arrangement and function of it's associated muscles.

Its connection with the pelvic limb, the axial skeleton and the rib and sternal apparatus characterizes the pelvis of crocodiles as an integral part of the whole body and demonstrates the importance of understanding the relationship between mechanical loading and pelvis architecture.

\section{Science communication of the Nanjing Museum of Palaeontology [poster presentation]}

Feng Weimin ${ }^{1}$

${ }^{1}$ Chinese Academy of Sciences, Nanjing Institute of Geology and Palaeontology, Nanjing, P. R. of China; E-mail:wmfeng@nigpas.ac.cn

The Nanjing Museum of Palaeontology, subordinated to the Nanjing Institute of Geology and Palaeontology, Chinese Academy of Sciences, is a modern museum with an exhibition, a collection, research and education. The museum was built and opened to the public by the end of the year 2005. Its total construction area is 8800 square meters, including exhibition area with 4200 square meters. 
The museum, based on the fossil specimens - of which a majority are invertebrate animals, ancient plants and microfossils - is by far one of the world's largest professional museums of palaeontology. It is also a national popular science education base. The museum collection is rich, the exhibits fine, and notably the Chengjiang fauna and Jehol biota including Sinosauropteryx fossil specimens are most precious, called a national treasure of fossils.

The museum tells the story of the earth and life evolution history. Its content includes a main theme exhibition titled Evolution of life and fourteen special exhibitions. The theme exhibition is composed of the Hall, Up the mountain path, Fossil mystery, The origin of the earth, The Precambrian, Palaeozoic, Mesozoic and Cenozoic. Special exhibitions are The Chengjiang fauna, Dinosaur world, Microscopy world, Biological landing, Invertebrate fossils, The Permian extinction, Crinoid fossil wall, Ancient botanical garden, The Jehol biota, The origins and evolution of birds, Oceans during the dinosaur era, Nanjing Homo erectus, Nanjing geohistory evolution and "Where do I come from?". These are presented with a lot of rare specimens, exquisite pictures, simulation models and landscape restoration, and use modern technology means such as multimedia. The exhibition fully demonstrates the mystery of the fossil and palaeontological diversity, reproduces the evolution of life interaction with the environment and its history of evolution, reveals the important events in the process of the evolution of life on the earth, shows the palaeontological discoveries and research achievements in China, inspire and promote the public interest and understanding of natural history.

The Museum launches several temporary popular science exhibitions every year, introducing progress of palaeontological research and the public hot spot of concern, often holds lectures on popular science inside and outside of the museum. The museum also organizes a series of activities to popularize scientific knowledge, including fossil appreciation, field study, making dinosaur models and palaeontological painting and essay competition at intervals. The museum successfully designs and manufactures some big popular science facilities, for example a large multi-touch system $4 \mathrm{~m}$ long and $1.5 \mathrm{~m}$ wide, allowing 10 people to play at the same time on the screen, an interactive display curtain $9 \mathrm{~m}$ long and a 3D cinema, to make the exhibition interesting, in cooperation with some computer companies. The museum also researches and develops many cultural creative products, including a voice reading pen, 3D animation about the diversity of life on the earth, etc. Especially, a set of senior popular science books about the origin and evolution of life have been published.

In a word, Nanjing Museum of Palaeontology is making constant progress in science communication. 


\title{
Plant-insect associations from the Late Triassic Yipinglang flora, southwestern China [oralpresentation]
}

\author{
Feng Zhuo ${ }^{1,2}$, Yang Jiyuan ${ }^{1}$, Chen Yuxuan ${ }^{1}$, Wei Haibo ${ }^{1}$, Liu Jianrong ${ }^{3} \&$ Ding \\ Jiahui $^{3}$ \\ ${ }^{1}$ Yunnan University, Yunnan Key Laboratory for Palaeobiology, Kunming, P. R. of China; \\ E-mail:jumperfeng@126.com \\ ${ }^{2}$ Chinese Academy of Sciences, Nanjing Institute of Geology and Palaeontology, State Key Laboratory of Palaeobiology \\ and Stratigraphy, Nanjing, P. R. of China \\ ${ }^{3}$ Lufeng Dinosaurian Museum, Lufeng, P. R. of China
}

Plants and insects are the two most species-rich groups, and together they represent nearly $3 / 4$ of the Earth's biodiversity today. The associations between plants and insects are generally recognised as a major force underlying the evolutionary development of both plants and insects, as well as of terrestrial ecosystems as a whole. According to the fossil records, the history of plant-insect associations can be dated back to the Carboniferous. However, the Triassic remains one of the poorest known periods in the evolutionary history of the terrestrial organisms, and the end of the Triassic period is pivotal in the evolution of modern ecosystems. Fossilised plant-insect associations may offer insights into the behaviour of ancient insects and provide information on the autecology of ancient plants. Chinese fossil records of pre-Triassic plant-arthropod associations mainly consist of detritivorous feeding traces, e.g. small-diametered coprolites and borings that are produced by oribatid mites from northern China and large-diametered coprolites of unidentified arthropods from southern China. The only example of herbivorous insect feeding traces in Palaeozoic Cathaysian flora is a few external feeding marks observed in the gigantopterid foliages from the Middle to Upper Permian of northern China. However, systematic insect feeding traces on a floral scale have not previously been investigated from China. Here we report the diverse insect-mediated damages on fossil foliages from the well-preserved late Late Triassic Yipinglang Flora of central Yunnan Province, southwestern China. The insect-mediated damages include apical feeding, marginal feeding, hole feeding, skeletonisation, slot-like feeding, galling, oviposition that are present on various types of plant foliages. In most cases, one plant leaf showed only one type of insect damage, but in few exquisite cases, multiple insect damages occurred in a single leaf. Our study of plant-insect association from China fills a gap in the published data on the palaeogeographical distribution and stratigraphic occurrences of plantarthropod associations. Our evidence of insect-mediated damage preserved in fossil plant parts may provide a better understanding of the evolutionary dynamics of plants and insects. 


\section{Palaeoecology and migration behaviour of fossil Late Palaeozoic to Early Mesozoic sharks revealed by stable and radiogenic isotopes [oral presentation]}

\section{Jan Fischer ${ }^{1}$}

${ }^{1}$ Geoskop Urweltmuseum/Burg Lichtenberg (Pfal₹), Thallichtenberg, Germany;

E-mail:j.jischer1@yahoo.de

The biogenic fluor-apatite in shark teeth is regarded as a valuable, diagenetically resistant geochemical archive of the ambient water chemistry and temperature at the time of tooth formation. So far, investigations have predominantly been and continue to be carried out on Middle-Late Mesozoic to Cenozoic material with a primarily palaeoclimatological and palaeoenvironmental focus. In contrast, little $\delta^{18} \mathrm{Op}$ or ${ }^{87} \mathrm{Sr} /{ }^{86} \mathrm{Sr}$ work has been conducted on shark teeth from the Palaeozoic and Early Mesozoic, while the available record is sparse, mostly unsystematic, and largely from outside of Europe. Since the palaeoecology of Late Palaeozoic and Early Mesozoic shark faunas from predominantly European basins is controversial, the tooth oxygen and strontium isotope composition is used here to differentiate between marine and freshwater signatures in order to decipher whether they had a diadromous or stationary freshwater lifestyle. Altogether, $430 \delta^{18} \mathrm{O}_{\mathrm{p}}$ values and 175 ${ }^{87} \mathrm{Sr} /{ }^{86} \mathrm{Sr}$ ratios derived from teeth of various fossil taxa of several time slices have been analysed for significance with regard to potential palaeoecological patterns such as as migration behaviour or life habitats. Tooth preservation was ascertained by cathodoluminescence microscopy.

The Palaeozoic (Late Carboniferous-Early Permian) tooth samples yield low $\delta^{18} \mathrm{OP}$ and high ${ }^{87} \mathrm{Sr} /{ }^{86} \mathrm{Sr}$ values deviating from bioapatite values expected for contemporaneous marine vertebrates and typical for freshwater settings. Some deviating $\delta^{18} \mathrm{O}_{\mathrm{P}}$ values from Spain and Germany can be attributed to significant evaporative enrichment of ${ }^{18} \mathrm{O}$ in the ambient water. This indicates a fully freshwater-adapted lifestyle for a variety of xenacanthiform and hybodontiform taxa in Late Palaeozoic European basins.

The Late Triassic (Rhaetian) tooth samples from bone beds of the Central European Basin indicate a shift from marine to brackish conditions in the south and west of the shallow epicontinental Rhaetian Sea towards extensively brackish conditions with low salinities in the east. Here, the $\delta^{18} \mathrm{O}_{\mathrm{p}}$ values indicate euryhaline adaption of hybodontiform sharks without a basin-wide migration pattern. Differences between taxa from the same site might indicate some degree of niche partitioning.

The $\delta^{18} \mathrm{OP}$ and ${ }^{87} \mathrm{Sr} /{ }^{86} \mathrm{Sr}$ datasets provided here clearly show similar quality of well-preserved Late Palaeozoic and Early Mesozoic bioapatite from shark teeth forming a geochemical archive of similar value to that of stratigraphically younger material. Moreover, the evaluation of the new $\delta^{18} \mathrm{Op}$ and ${ }^{87} \mathrm{Sr} /{ }^{86} \mathrm{Sr}$ record proves its worthwhile use in order to contribute to long-lasting palaeobiological controversies. Therefore, further isotope investigations of old shark remains show con- 
siderable potential for growth in understanding regarding palaeoecology, palaeoenvironmental conditions as well as palaeoclimatology, in marine and non-marine areas.

\section{Stratigraphic record, producer assignment and phylogeny of chondrichthyan egg capsule morphotypes [posterpresentation]}

Jan Fischer ${ }^{1,2}$, Martin Licht ${ }^{3}$, Jörg W. Schneider ${ }^{1}$, Jürgen Kriwet ${ }^{4}$, Michael Buchwitz $^{1} \&$ Ilja Kogan ${ }^{1}$

${ }^{1}$ Technical University Bergakademie Freiberg, Institute of Geology, Department of Palaeontology, Freiberg/Sa., Germany;

E-mails:j.fischer1@yaboo.de; schneidj@geo.tu-freiberg.de; mbuchwit?@web.de@i.kogan@gmx.de

${ }^{2}$ Geoskop Urweltmuseum/Burg Lichtenberg (Pfali), Thallichtenberg, Germany

${ }^{3}$ Museum für Naturkunde, Leibniz-Institut für Evolutions- und Biodiversitätsforschung, Berlin, Germany;

E-mail:martinlicht1@arcor.de

${ }^{4}$ University of Vienna, Department of Palaeontology, Vienna, Austria; E-mail: juergen.krivet@univie.ac.at

Chondrichthyan egg capsule fossils have been described since the 19th century, but the early finds were often misinterpreted as various plant organs like inflorescences or fructifications, stems of algae or sometimes even as coprolites. Since the initial discovery of these fossils, our knowledge of their morphological and taphonomical variability, geographical and stratigraphical distribution, and potential producers has significantly advanced. Currently, ten distinct morphotypes of fossil and extant chondrichthyan egg capsules are discerned: Palaeoxyris; Vetacapsula; Crookallia; Fayolia, holocephalan callorhinchid, rhinochimaerid, and chimaerid types, fossils summarized as Chimaerotheca; batoid type, fossils summarized as Rajitheca; scyliorhinid type, fossils summarized as Scyliorbinotheca; extant orectolobid type; extant heterodontid type. These represent a range of morphological traits. Eight morphotypes are known from the fossil record with five types being exclusively represented by fossil finds.

A phylogenetic analysis of all extant and currently known fossil chondrichthyan egg capsule types based on all available discrete morphological characters indicates that holocephalan morphotypes cluster together in one branch while the elasmobranchs form a sister branch and feature many character transformations since the Late Palaeozoic. Moreover, the enigmatic Carboniferous egg capsule morphotypes Vetacapsula and Crookallia form a clade together with the egg capsule morphotype of chimaerid holocephalans. Assignment of the very incompletely known Pennsylvanian type Scapellites is still unclear, but the preserved rhomboidal patterns on the fossil finds as result of an original composition of helicoidally twisted bands point to an elasmobranch producer.

All chondrichthyan capsules can be traced back to one hypothetical primordial morphotype with a broad, lateral, ribbed collarette combining features from callorhinchid holocephalans and a putative placoderm capsule. Given the similarity 
of their egg capsules holocephalans might be more closely related to certain placoderms than to elasmobranchs.

\title{
Morphometry, taxonomy, autecology and palaeobiogeography of Prionoceratidae (Ammonoidea) [oral presentation]
}

\author{
Tobias Fischer ${ }^{1} \&$ R. Thomas Becker ${ }^{1}$ \\ ${ }^{1}$ Westfälische Wilhelms-Universität Münster, Institut für Geologie und Paläontologie, Münster, Germany; \\ E-mail:t_fisc09@uni-muenster.de
}

The taxonomy of Upper Devonian (UD IV-VI) Prionoceratinae from $\mathrm{N}$ and $\mathrm{S}$ of the Prototethys (Rhenish Massif, Franconia, Anti-Atlas of Morocco, Saoura Valley of Algeria) was restudied based on their ontogenetic morphometry. Involute early stages, with a stagnant or closing umbilicus from the $2^{\text {nd }}$ whorl on, contrast with more evolute juveniles with an umbilical opening at least until the $4^{\text {th }}$ whorl. The following groups are recognized:

Prionoceras: involute, regular shell constrictions on flanks

"Prionoceras": very similar but evolute

Rectimitoceras: involute

lineare Gp.: no or irregular varices, low/moderate whorl expansion (WER)

bertchogurense Gp.: no shell constrictions or varices, high WER

liratum Gp.: shell constrictions tripartite and with lips, low/moderate WER

simile $\mathrm{Gp}$. : fine shell constrictions, low/moderate WER

Mimimitoceras: evolute

trizonatum Gp.: shell constrictions tripartite and with lips, low/moderate WER

?quadripartitum $\mathrm{Gp}$.: irregular varices, low WER

?pompeckji Gp.: with or without varices, moderate/high WER

kiense Gp.: umbilicus closes very gradual and late, no shell constrictions

Involute and evolute groups occur commonly in Germany, whereas only two involute $R$. lineare could be verified in the Famennian of Morocco. This inhomogeneous distribution may reflect the mostly demersal mode of life and palaeogeographical barriers in the Prototethys.

\section{Raja Ampat: A Hotspot of Modern Foraminiferal Diversity [oral presentation]}

\section{Esther-Meena Förderer ${ }^{1}$ \& Martin R. Langer ${ }^{1}$}

${ }^{1}$ Rheinische Friedrich-Wilhelms University, Steinmann Institute of Geology, Mineralogy and Palaeontology, Bonn, Germany; E-mail:m.foerderen@uni-bonn.de

Raja Ampat is a conglomerate of more than 1500 islands that form an archipelago off the northwestern coast of the Birds Head Peninsula in Indonesia's West Papua 
province. To date, its remote location and difficult access conditions have prevented large-scale studies on benthic foraminifera. We have analyzed a comprehensive set of sediment samples and identified the composition and diversity of shallow-water foraminifera present in this region. The sample material covers the full range of existing macrohabitats and a depth range between 1 to 50 meters. All taxa were identified to species level covering the existing types of macrohabitats present in this region. An extraordinary high species richness of benthic reefal foraminifera was recovered and specific diversity was compared to other IndoPacific reefal sites. Our findings suggest that Raja Ampat constitutes a unique hotspot of marine diversity and represents one of the world's biologically richest locations among reefs in modern oceans.

\title{
On the influence of heterochronic patterns in the cranial shape of saurischian dinosaurs [oral presentation]
}

\section{Christian Foth $^{1}$ \\ 'Bayerische Staatssammlung für Paläontologie und Geologie, München, Germany; E-mail: christian.foth@gmx.net}

Saurischian dinosaurs represent one of the most successful archosaur groups in the Mesozoic in terms of species diversity, diet spectrum, body size and cranial shape. Cranial diversity includes various kinds of overall shapes as well as the convergent formation of beaks and a variety of horns and crests. Here, the cranial diversity of Saurischia is investigated for heterochronic patterns by comparing ontogenetic and evolutionary shape changes with help of geometric morphometrics. Excepting some similar trends affecting snout shape and orbit size, skull shape change during ontogeny is not uniform, and the found differences in ontogenetic trajectories may underpin the huge diversity found in saurischian cranial morphology strongly affected by heterochronic events. Evidence for peramorphosis in cranial shape was found within Sauropodomorpha, basal theropods, Tyrannosauroidea as well as some maniraptoran groups, whereas paedomorphic events may have occurred in some basal theropod species, in basal coelurosaurs and in the stem-line of Avialae. These heterochronic events appear to be correlated with body size evolution and also feeding behaviour.

\section{Microvertebrate analyses extend the ichthyodiversity of the continental Triassic Madygen Formation, Kyrgyzstan [poster presentation]}

Franziska Franeck ${ }^{1}$, Jan Fischer $^{2}$, Ilja Kogan ${ }^{3}$, Sebastian Voigt $^{2}$ \& Jörg W. Schneider ${ }^{3}$

\author{
${ }^{1}$ University of Oslo, Department of Geosciences, Oslo, Norway; E-mail:f.franeck@gmx.net \\ ${ }^{2}$ Geoskop Urweltmuseum/Burg Lichtenberg (Pfaly), Thallichtenberg, Germany
}


${ }^{3}$ Technical University Bergakademie Freiberg, Institute of Geology, Freiberg/Sa., Germany

The Madygen lagerstätte (Kyrgyzstan, Central Asia) is a Middle Triassic (Ladinian) assemblage of continental biota mainly preserved in lacustrine deposits. Wet chemical processing of dark greyish bivalve-rich mudstone revealed a variety of isolated fish remains that have been compared with (articulated and disarticulated) material from other sites of the study area. A dipnoan and six actinopterygians have hitherto been described based on articulated specimens as well as two chondrichthyans documented by teeth and egg capsules. Isolated actinopterygian scales can so far be subdivided into 10 groups according to their surface morphology. Whereas several of these groups could be unambiguously assigned to known taxa like Saurichthys orientalis and Oshia ferganica, others could not. Teeth and dermal denticles of the hybodontid Lonchidion ferganensis as well as denticles tentatively referred to xenacanthiform sharks extend the database on the Madygen chondrichthyans. The presence of microremain types not documented in the articulated fish record indicates a higher diversity of the ichthyofauna.

\section{Palaeontology in Palaeoclimatological Research on the Tibetan Plateau [keynote presentation]}

\section{Peter Frenzel $^{1}$}

${ }^{1}$ Friedrich-Schiller-Universität, Institut für Geowissenschaften, Jena, Germany; E-mail: peter.frenzel@uni-jena.de

Bioindicators are amongst the most valuable proxies in Quaternary palaeolimnology. Within the priority program 1372 TiP, funded by the German Research Foundation and in close collaboration with Chinese institutes, as for instance the Institute of Tibetan Plateau Research of the Chinese Academy of Sciences, monsoonal shifts in time and space are reconstructed using Quaternary lake sediments. Pollen, Ostracoda, Gastropoda and Cladocera as well as related stable isotope and trace element signatures and biomarkers are the most important palaeontological proxies used from these sediments. Ostracoda are in the focus of our research. They are the most abundant zoological proxies from the predominantly brackish water lakes of the Tibetan Plateau. Ecological approaches as well as stable isotope and element shell chemistry enable reconstructing lake level and habitat changes, precipitation/evaporation ratios, salinity, temperature and productivity shifts of the studied lake systems in altitudes of $4500 \mathrm{~m}$ a.s.l. or more.

The presentation gives an ostracod focused overview on palaeontological research and applications used for palaeoclimatology in the Quaternary of the Tibetan Plateau. 


\title{
The Working Group "Origin of Life" of Göttingen Academy of Sciences and Humanities [oralpresentation]
}

\author{
Hans-Joachim Fritz ${ }^{1,2}$ \\ ${ }^{1}$ Georg-August University, Institute of Microbiology and Genetics, Göttingen, Germany; \\ E-mail: hansj.fritz@gmail.com \\ ${ }^{2}$ Georg-August University, Courant Research Centre Geobiology, Göttingen, Germany
}

In cooperation with the Courant Research Centre Geobiology, Göttingen Academy of Sciences is operating a Working Group under the title "Origin of Life" (http://oolife.adw-goe.de/), which brings together scientists from a variety of disciplines in Earth, Physical and Life Sciences. Until present, core questions of the Origin of Life problem have typically been approached from the view angle of only a single discipline. In contrast, the Working Group sees great potential in combining, in each individual case, the diverse expertise represented by its members. This philosophy will be illustrated by the preliminary outline of a project the Working Group is presently about to embark upon.

Throughout contemporary life, chemical energy of nutrients is transiently stored in the phosphoric acid anhydride group (present in ATP, inorganic polyphosphates and the like) which combines high negative free energy of hydrolysis with robust kinetic stability in aqueous solution. The ubiquitously uniform nature of these essentials of energy metabolism attests to their very old evolutionary age and it has been speculated repeatedly that polyphosphates were, indeed, the primary source of chemical energy during a pre-biotic stage of organic 'evolution' (i.e. before the advent of energy-converting metabolism).

In extrapolating back from present geochemistry, however, a few problems with such a scenario become evident: While phosphoric acid anhydride $\left(\mathrm{P}_{4} \mathrm{O}_{10}\right)$ has been detected in the exhalations of certain volcanoes, orthophosphate and polyphosphates are hardly soluble in the presence of calcium ions - hence the very low phosphorus content of sea water. Any attempt to follow back to its roots the history of the phosphoric acid anhydride group as a storage device and possible primary source of chemical energy has to address a number of questionss such as, i.a., the following:

- What was the chemical status of phosphorus on the early Earth - in particular with respect to oxidation stage ?

- What chemical fate did it have until the first emergence of life ?

- To which extent is plausible argument supported by physical evidence (geological record, chemical composition of meteorites etc.) ?

- How do phosphorous acid anhydrides compare to their respective $\mathrm{P}(\mathrm{V})$ counterparts (solubility, kinetics and thermodynamics of hydrolysis)?

- How could early energy flows, possibly resting on other chemical reactions than condensation/hydrolysis of (poly)phosphates, be channeled into present biochemistry along a continuous evolutionary trajectory? 


\title{
Anomodonts (Tetrapoda, Therapsida) as a model group to study the end-Permian mass extinction and its aftermath [oralpresentation]
}

\author{
Jörg Fröbisch ${ }^{1}$
}

${ }^{1}$ Museum für Naturkunde, Leibniz-Institut für Evolutions- und Biodiversitätsforschung, Berlin, Germany;

E-mail:joerg.froebisch@mfn-berlin.de

Anomodont therapsids are an ideal case study to investigate the impact and subsequent recovery of the end-Permian mass extinction (EPME) on land. This most speciose and morphologically diverse clade of Permian-Triassic tetrapods dominated as herbivores the terrestrial vertebrate ecosystems in numbers of individuals and occupation of ecological guilds. They ranged in body size from small (10$15 \mathrm{~cm})$ to large $(2-3 \mathrm{~m})$ and included fully terrestrial, semi-aquatic, fossorial and arboreal ecomorphs. Anomodonts had a global distribution and represent one of only few survivors of the EPME and the only tetrapod clade that experienced a true bottleneck with radiations before and after. Taxic diversity and morphological disparity are decoupled in anomodont history, with a macroevolutionary bottleneck in one (taxic diversity) apparently not affecting long-term trends in the other (disparity). Character completeness metrics indicate that the quality of the anomodont fossil record is exceptionally good, but it remains unclear whether this pattern is a result of the unrivalled fossil record in the South African Karoo Basin or genuine and unique to the clade.

\section{Coleoid cephalopods and their high-fidelity preservation in Konservat-Lagerstätten [oral presentation]}

\author{
Dirk Fuchs ${ }^{1}$, Helmut Keupp ${ }^{1} \&$ Philip R. Wilby ${ }^{2}$ \\ ${ }^{1}$ Free University, Institute of Geological Sciences, Berlin, Germany; \\ E-mails:drig@zedat.fu-berlin.de \& keupp@zedat.fu-berlin.de \\ ${ }^{2}$ British Geological Survey, NERC - BGS Keyworth, Nottingham, U.K.; E-mail:prwi@bgs.ac.uk
}

"The preservation potential of the mainly soft bodied coleoids is low". This pessimistic attitude was long-time anchored in the mind of natural scientists. Admittedly, our palaeobiological understanding of this very successful group of marine invertebrates is still hampered by fossil gabs, however, it is noteworthy to emphasise that already the pioneers in coleoid research obtained a very precise picture of their general morphology from Konservat-Lagerstätten such as the Posidonia Shales of Holzmaden (Toarcian), the Oxford Clay of Christian Malford (Callovian), or the Solnhofen Plattenkalks (Tithonian).

Reports on extra-ordinarily well preserved soft tissues of coleoids started in the early 30ies of the $19^{\text {th }}$ century with discoveries of phosphatised mantle, arm and fin musculature. The knowledge was continuously increasing particularly since the discoveries of the Lebanon Plattenkalks in the 1870ies. Today, teuthologists are 
able to access even highly delicate anatomical features of the respiratory, circulatory, excretory, and reproductive systems.

It is the aim of the present talk to introduce the audience into a remarkable diversity of anatomical character complexes preserved in the Coleoidea, to provide a key for systematic implications, and to give an outlook of what can be expected from still locked data. To conclude, it is our aim to convince the audience that the preservation potential of the mainly soft bodied coleoids is anything but poor and instead the best among marine organisms.

\title{
A new enantiornithine bird from Early Cretaceous Jehol Biota, northeastern China [posterpresentation]
}

\author{
Gao Lin ${ }^{1}, \mathbf{H u}$ Dongyu ${ }^{1}, \mathbf{X u}$ Xing $^{2} \&$ Hou Lianhai ${ }^{1,2}$ \\ 1 Shenyang Normal University, Paleontological Institute, Shenyang, P. R. of China; \\ E-mails:gaolin0911@gmail.com \& budongyu1@126.com \\ ${ }^{2}$ Chinese Academy of Sciences, Institute of Vertebrate Paleontology and Paleoanthropology, Beijing, P. R. of China; \\ E-mails:xingxu@vip.sina.com \& houlianbai@synu.edu.cn
}

The Jehol Biota is an ecosystem of northeastern China between 131 to 120 million years old. As a successful branch of Mesozoic bird evolution, Enantiornithes is the most abundant and diverse among the Jehol vertebrates and displays high ecological adaptation to the Jehol ecosystem. In the last two decades, numerous enantiornithine fossils have been recovered and over 15 species have been named; they appear to include arboreal insect-catchers, waders, and fish-catchers. These discoveries have greatly improved our understanding of the early evolution of the group. Here we report a new enantiornithine specimen, a nearly complete, mostly articulated skeleton preserved in a slab (CSFM-B00002a) and counter slab (CSFMB00002b), from the Lower Cretaceous Dabeigou Formation of Fengning County, northern Hebei, China. This new bird is about the size of a swallow; it was probably a young individual at the time of death as indicated by the incomplete fusion of the synsacrum and incomplete ossification of the sternum. It differs from other known enantiornithines by a unique combination of following features: rostrum occupying half length of skull; teeth on upper jaw much more than on lower jaw; lateral margin of coracoid straight, caudal end of xiphoid process forked laterally as a goblet-like shape; forelimbs longer than hind limbs (about $115 \%$ length of hind limbs), alular digit not extending as far distally as major metacarpal; metatarsals III and IV subequal in length, pedal digit III longer than metatarsal III; a pair of straplike tail feathers tapered distally. The new specimen likely represents a new species and new ecological style of Enantiornithes, and further improves our understanding of the early evolution of the group.

This study is supported by the NSFC (41172026, 41120124002), and Natural Science Foundation of Liaoning Province (201102199) and Education Bureau Foundation (LR2012038). 
First description of tropical angiosperm woods from a Middle Eocene fossil lagerstätte in Laredo, Texas, USA [posterpresentation]

\author{
Nicole Garten ${ }^{1} \&$ Carole T. Gee ${ }^{1}$ \\ ${ }^{1}$ Rheinische Friedrich-Wilhelms University, Steinmann Institute of Geology, Mineralogy and Palaeontology, Bonn, \\ Germany; E-mails:nicole-garten@web.deßrgee@uni-bonn.de
}

\begin{abstract}
Although the Casa Blanca Biota (Laredo Formation, Claiborne Group, SW Texas) is a middle Eocene fossil lagerstätte known for its invertebrates, vertebrates, leaves, pollen and spores, fossil wood from this site has not been studied up to now. Previous paleoecological analysis on the fossil fauna and flora suggest the occurrence of Nypa palms growing in a brackish water mangrove habitat and, farther inland, a lowland tropical rainforest. Recent fieldwork has resulted in the recovery of new fossil wood specimens. This poster presents the first description of three angiosperm wood taxa from this Eocene habitat, as well as a new method for the thin-sectioning of fossil wood. Here we show that the fossil woods came from broadleaved trees that grew under true tropical conditions. Together with the previously found angiosperm pollen, these woods confirm the presence of a tropical rainforest dominated by dicot trees in the lowlands. The fossil leaves, wood, pollen and spores, and vertebrates all come from a single horizon at the site, an unusual feature of this fossil lagerstätte.
\end{abstract}

\title{
Triple oxygen isotope composition of mammalian bioapatite from the Paleocene-Eocene transition - a combined proxy for fluctuations in air temperature and atmospheric $\mathrm{CO}_{2}$ concentration [oral presentation]
}

\author{
Alexander Gehler ${ }^{1,2,3}$, Andreas Pack ${ }^{3} \&$ Philip D. Gingerich ${ }^{4}$ \\ ${ }^{1}$ Göttingen Academy of Sciences, long-term project "Johann Friedrich Blumenbach - online" of the Union of the \\ German Academies of Sciences and Humanities, Göttingen, Germany; E-mail: agebler@gwdg.de \\ ${ }^{2}$ Georg-August University, Geoscience Museum and Geopark, Göttingen, Germany \\ ${ }^{3}$ Georg-August University, Geoscience Centre, Department of Isotope Geology, Göttingen, Germany \\ ${ }^{4}$ The University of Michigan, Department of Earth and Environmental Sciences and Museum of Paleontology, Ann \\ Arbor, Micbigan, U.S.A.
}

The Paleocene-Eocene transition is associated with an abrupt environmental change, characterised by increased temperatures of several ${ }^{\circ} \mathrm{C}$ and a globally abundant large negative carbon isotope excursion (CIE) within a period of less than 200,000 years. This time interval is termed the "Paleocene-Eocene Thermal Maximum" (PETM). Temperature change and CIE across the PETM are well documented by various proxies, and the connection to enhanced greenhouse gas levels (most likely $\mathrm{CO}_{2}$ and/or $\mathrm{CH}_{4}$ ) is widely accepted. However, the source and fraction of these greenhouse gases are still discussed controversially. 
In the past, oxygen isotope analyses $\left(\delta^{18} \mathrm{O}\right)$ of mammalian bioapatite from pre-, peak- and post-PETM strata have been used successfully to track the respective temperature change. Analysing the triple oxygen isotope composition $\left(\delta^{17} \mathrm{O}, \delta^{18} \mathrm{O}\right)$ combines this approach with a newly developed method that attempts to record both, temperature and $\mathrm{CO}_{2}$ fluctuations simultaneously by a single proxy.

Triple oxygen isotope data from a sample series of tooth enamel of the condylarth mammal Ectocion from the Clark Forks Basin (Wyoming, USA) agree well with previous results of PETM temperature change and support the thesis of carbon input from an extremely $\delta^{13} \mathrm{C}$ negative carbon source (i.e. $\mathrm{CH}_{4}$ ) associated with only moderate $\mathrm{CO}_{2}$ change.

\title{
Important types and distinguished donators - palaeontological objects of the Blumenbach-collection in the Göttingen Geoscience Museum [posterpresentation]
}

\author{
Alexander Gehler ${ }^{1,2}$ \& Mike Reich M $^{1,2,3}$ \\ ${ }^{1}$ Göttingen Academy of Sciences, long-term project "Tohann Friedrich Blumenbach - online" of the Union of the \\ German Academies of Sciences and Humanities, Göttingen, Germany; E-mail: agebler@gwdg.de \\ ${ }^{2}$ Georg-August University, Geoscience Museum and Geopark, Göttingen, Germany; E-mail: mreich@gwdg.de \\ ${ }^{3}$ Georg-August University, Geoscience Centre, Department of Geobiology, Göttingen, Germany
}

After receiving a doctor's degree in 1775 with his dissertation entitled De generis bumani varietate nativa (On the natural varieties of mankind) Johann Friedrich Blumenbach (1752-1840) was appointed to an extraordinary professor in 1776, from 1778 onwards a full professor of medicine and natural history at the University of Göttingen. He has also been the head of the 'Royal Academic Museum'. With his lectures on 'Natural History' between 1777 and 1837, he influenced a large number of students which often kept faith with him in later years and supplied him with objects for his collections. In addition, he maintained a broad scientific network to German and foreign colleagues and private collectors.

During the decades of his professional career, Blumenbach brought together an extraordinary collection of natural history objects for the Academic Museum and also held a large private collection, which was purchased by the University of Göttingen after his death. The palaeontological objects of those collections today are located within the collections of the Geoscience Museum of the Göttingen University.

Blumenbachs palaeontological bequest includes fossils from Cambrian to Quaternary strata, among them important type material, e.g. from late Quaternary large mammals such as Mammuthus primigenius and Coelodonta antiquitatis as well as from invertebrate taxa like the brachiopod Pliothyrina grandis and the barnacle Balanus porosus from Oligocene strata of northern Germany, the polychaete Serpula coacervata from the Berriasian of Lower Saxony or the coral Thamnopora cristata from the Devonian of the Harz Mountains. 
His national and international contacts provided him with a large number of fossil specimens from all over the world. The long list of donators includes such distinguished names like Georg Thomas von Asch (1729-1807), Joseph Banks (1743-1820), William Buckland (1784-1856), Guillaume-Antoine Deluc (1729_ 1812), Jean-André Deluc (1727-1817), Johann Wolfgang von Goethe (1749-1832), Adolf von Hüpsch (1730-1805), Ernst Friedrich von Schlotheim (1764-1832) Vasilij M. Severgin [Васимий М. Севергин] (1756-1826), Alexander von Humboldt (1769-1859), Wilhelm Gottlieb Tilesius von Tilenau (1769-1857) and Alexandre Brongniart (1770-1847).

\title{
Application of two-dimensional bar code in fossil specimen management [posterpresentation]
}

\section{Geng Binghe ${ }^{1}$, Zheng Fang ${ }^{1} \&$ Zhang Wei ${ }^{1}$}

${ }^{1}$ Chinese Academy of Sciences, Institute of Vertebrate Paleontology and Paleoanthropology, Beijing, P. R. of China; E-mail: gengbinghe@ivpp.ac.cn

Thanks to a lot of outstanding qualities, the technology of two-dimensional bar code has been widely used in supermarkets, shopping malls, manufacturing industry, trade, logistics, libraries and other fields. Here, we briefly introduce the characteristics of two-dimensional bar code technology and its new application in fossil specimen management. The bar code will take the place of the complicated traditional hand-signature, when researchers borrow specimens from our collection, realizing a paperless office in the management of collections. Meanwhile, collection managers can use hand-held scanners to regularly check on specimens, which greatly improves the work efficiency.

\section{A fresh look on fossil Gobioids from the Miocene of Europe [poster presentation]}

\author{
Christoph Gierl ${ }^{1}$ \& Bettina Reichenbacher ${ }^{1}$ \\ ${ }^{1}$ Ludwig-Maximilians University, Department of Earth and Environmental Sciences, Section Palaeontology and \\ Geobiology,Munich,Germany; E-mails: chris.gier@tt-online.de \& b.reichenbacher@Iræ.uni-muenchen.de
}

The gobioid fish species Gobius brevis (Agassiz, 1839) from the Miocene of the SGerman Molasse Basin and Upper Rhine Graben is one of the few examples of fossil gobies of which the first description was based on a skeleton. Most fossil gobioid species are solely based on otoliths, because of their better chance of conservation. After its first description, it took more than 150 years that this species got a revisit. A rare case of skeletons with otoliths in situ helped not only to add more skeletal features to the description but also to the knowledge of how this species' otoliths look like. However, due to the close relationship of G. brevis with 
G. multipinnatus in terms of otolith morphology and also because of contradictory descriptions in older literature, a close look at these fishes is once again of high interest. Re-investigation of specimens from museum collection and new findings may help to solve the puzzle if this is a true goby and if, among all the G. brevis specimens, another so far uncharted species is hiding.

\section{High-resolution analyses and reconstruction of the autecology of endemic Lake Pannon ostracods (Late Miocene; Styrian Basin, Austria) [oral presentation]}

Frank Gitter ${ }^{1,2}$, Martin Gross ${ }^{1}$ \& Werner E. Piller ${ }^{2}$

${ }^{1}$ Universalmuseum Joanneum, Graz, Austria; E-mail: frank.gitter@museum-joanneum.at

${ }^{2}$ Karl-Franzens University, Institute for Earth Sciences, Graz, Austria

Located approx. $45 \mathrm{~km} \mathrm{SE}$ of Graz (SE-Austria, 15 $57^{\prime} 16^{\prime \prime} \mathrm{E} / 46^{\circ} 54^{\prime} 15^{\prime \prime} \mathrm{N}$ ) in the Styrian Basin, the Mataschen clay pit represents an exceptional window into a nearshore community of Lake Pannon during Early Tortonian times. The $\sim 30 \mathrm{~m}$ thick succession represents a transgressive-regressive phase with a transition from swampy to limnic-deltaic environments. Here we present the results of a multiproxy palaeoecological reconstruction of a $\sim 2.3 \mathrm{~m}$ thick high-resolution interval covering a maximum of 3500 years.

The high-resolution section includes initially shallow, slightly brackish water conditions with depleted oxygenation, before a transgression leads to salinities above 15 psu and better oxygenated conditions. At the top, a meromictic system established due to an increasing fluvial influx. While ostracod species like Cyprideis mataschensis seem to tolerate a wide range of salinities and depleted oxygenation, others (i.a. C. kapfensteinensis, Hemicytheria folliculosa and Callistocythere sp.) are more stenoecious in relation to those parameters. By refining the ecological ranges of endemic ostracod species, palaeological conclusions can be significantly improved.

This work is supported by the FWF (P21748-N21).

\section{Depth distribution and convergent evolution of microboring organisms [oral presentation]}

Stjepko Golubić ${ }^{1}$ \& Gudrun Radtke ${ }^{2}$

'Boston University, Biological Science Center, Boston, Massacbusetts, U.S.A.; E-mail: golubi@@bu.edu

${ }^{2}$ Hessian Agency for the Environment and Geology, Wiesbaden, Germany; E-mail: gudrun.radtke@blug.hessen.de

The carbonate boring habit evolved among light-dependent, phototrophic organisms as well as among light-independent organotrophic ones. Although microboring activity is most intensive in shallow tropical waters, the destruction of shells 
and other skeletal carbonates by microboring organisms occurs at all depths and in a wide range of latitudes. The intensity of carbonate removal depends on abundance of microboring organisms, available energy and on the time of the substrate exposure to microboring activity. The use of microboring traces as paleoecological, specifically paleobathymetric indicators depends on the recogniton of the organism based on its trace, i.e. on distinction between traces formed by light-dependent from those formed by light-independent microboring organisms. The approaches include extraction and identification of resident microborers in modern environmental settings and comparing them with their traces as well as pattern recognition in assessing entire modern and fossil ichnocoenoses. The present study compares adaptive strategies in phototrophic $v$ s. organotrophic euendoliths that enable them to grow and survive in their peculiar habitat. The similarities illustrate solutions to common problems, while the differences point to diversification in particular ecological niches. Convergent morphological features may have evolved in unrelated microorganisms, which requires additional caution in their characterization and recognition and, by extension, a refinement in the use of traces as bathymetric indicators.

The present contribution contrasts two subtidal end member assemblages in vertical distribution of modern microbial euendoliths and their traces: Microborings in shoaling ooids in shallow waters and in shell fragments on the surface of deep sea sediments. The distinction is first assessed at the level of pattern recognition, followed by identification of convergent morphologies that require qualitative and quantitative characterizations.

\title{
Bioerosion and Biokarst on Mediterranean Coastal Limestone [posterpresentation]
}

\author{
Stjepko Golubić ${ }^{1}$, Jürgen Schneider ${ }^{2}$, Seong-Joo Lee $^{3} \&$ Gudrun Radtke ${ }^{4}$ \\ 'Boston University, Biological Science Center, Boston, Massachusetts, U.S.A.; E-mail: golubi@@bu.edu \\ ${ }^{2}$ Georg-August University, Geoscience Centre, Department of Sedimentology and Environmental Geology, Göttingen, \\ Germany \\ ${ }^{3}$ Kynngpook National University, Department of Geology, Daegu, South Korea \\ ${ }^{4}$ Hessian Agency for the Environment and Geology, Wiesbaden, Germany
}

The shaping of limestone rocky coasts, marked by a dark belt along the zone of the impact by tides and waves, has been widely considered the work of inorganic geological and chemical forces such as corrosion and abrasion by the sea. However, a closer microscopic view uncovers complex biological interrelationships, including several tears of foodwebs. A particular rich assembly of micro- and macro-organisms flourish along these zones, while confronting steep gradients of harsh environmental changes across the zone and severe fluctuations of temperature and salinity over time. Temperature and radiation changes increase dramatically across 
peritidal ranges, while salinity may range from near zero, following extended rains, up to extreme hypersalinity with precipitation of gypsum and seasalt.

A closer microscopic image of the dark coastal margin reveals densely packed cyanobacteria excavating millions of microscopic perforations into the rock, while also producing extracellular sun-screening pigments in their exopolymer envelopes. The microbial community is supported by cyanobacterial populations of high density and productivity as the principal primary producers of the system. Their main geological impact consists of biocorrosion, followed by bioabrasion of their principal grazer community consisting of gastropods, polyplacophores, echinoderms and fishes. The lithological and sedimentological consequences of this biointegrated activity as well as the preservation potential of this community and the interpretation of its fossil record is discussed.

\title{
Reef development and marine ecosystems of the Late Carboniferous in South Guizhou, China [oral presentation]
}

\author{
Gong Enpu ${ }^{1}$, Zhang Yongli ${ }^{1}$, Guan Changqing ${ }^{1}$ \& Chen Xiaohong ${ }^{1}$ \\ ${ }^{1}$ Northeastern University, Department of Geology, Shenyang, P. R. of China; E-mail: gongep@mail.neu.edu.cn
}

The Late Carboniferous reefs are widespread and well exposed in South Guizhou, China. Some environmental factors of marine ecosystems could have affected the reef development. Basement nature is a key factor for organism colonization. There was no large scale chemical hard substrate for larval settlement on the reef in the Late Carboniferous in the region; reef-building organisms only grew on biogenic hard substrate.

The brachiopod shell $\delta^{18} \mathrm{O}(\mathrm{V}-\mathrm{PDB})$ values of South Guizhou indicate that Qiannan region sea surface temperature was $23-30^{\circ} \mathrm{C}$ during the Late Carboniferous, belonging to the warm and moist climate. Such a high seawater temperature indicates that the paleogeographic position of South Guizhou was in low-latitude and very close to the equator during the Late Carboniferous. This region may not have been influenced by the glaciation of Gondwana.

During this period, the reef environment gradually stabilized, the reef size increased, the reef structure became more complex and more mature in South Guizhou. Because the temperature and chemical conditions of marine ecosystems were suitable for reefs gradually into a stable equilibrium phase.

Fluctuation of shelf basin redox conditions in the early Ediacaran: evidence from Lantian Formation black shales in South China [oral presentation]

Guan Chengguo ${ }^{1}$, Zhou Chuanming ${ }^{1}$, Wang Wei $^{1}$, Wan Bin ${ }^{1}$, Yuan Xunlai ${ }^{1}$ \& Chen Zhe ${ }^{1}$ 
${ }^{1}$ Chinese Academy of Sciences, Nanjing Institute of Geology and Palaeontology, State Key Laboratory of Palaeobiology and Stratigraphy, Nanjing, P. R. of China; E-mail: Guanchengguo1988@163.com

Lantian macrofossils are preserved in situ as carbonaceous compressions on the bedding surfaces of the Ediacaran Lantian Formation black shales in southern Anhui Province, South China. Integrated stratigraphic correlations suggest that the Lantian biota may have occurred in the early Ediacaran Period (635-580 Ma). Diverse benthic sessile algae and possible metazoans with tentacles comparable with modern eumetazoans in the Lantian biota suggest that the early Ediacaran ocean may have been oxidized, which is inconsistent with most previous studies indicating that the Neoproterozoic deep ocean remained anoxic or even euxinic until at least the middle Ediacaran ( $\sim 580 \mathrm{Ma})$.

To reveal the ocean redox condition of the Lantian basin in the early Ediacaran Period, we carried out petrological observations, lamina-scale pyrite framboid measurements and $\delta^{34} \mathrm{~S}_{\mathrm{py}}$ analysis, as well as Fe speciation and redox-sensitive trace element (RSTE) analyses of the Lantian Formation black shales.

The Lantian black shales are mainly fine laminated (millimeter-scale), organicrich mudstone and siltstone, without any wave-, storm-, and gravity-generated coarse-grained layers, suggesting deposition well below the storm wave base in a deep and quiet basin. Fe speciation analysis indicates that the macrofossil-bearing black shales were deposited in an euxinic environment, while lamina by lamina pyrite framboid measurements indicate that the Lantian black shales were deposited in fluctuant redox conditions.

The lamina-scale $\delta^{34} S_{\mathrm{py}}$ values show pronounced fluctuations (ranging from $-20.5 \%$ to $2.3 \%$ ) and significant ${ }^{34}$ S-depleted values compared to coeval seawater sulfate $(+30-35 \%)$. The Lantian black shales thus display Phanerozoic-type S-isotopic fractionations, and provide strong evidence for sulfate-rich conditions in the Ediacaran ocean.

To reconcile the geochemical data with the occurrence of Lantian macroscopic organisms, we propose that rapid redox condition changes may have occured in the Lantian shelf basin during the early Ediacaran. Fe speciation measurements for the bulk rock samples do not have sufficient resolution to show this frequent change. The frequent changes in redox condition in the Lantian shelf basin may have facilitated the blossom and preservation of the macroscopic Lantian biota.

\title{
Famennian conodont faunas in olistostromes at Taourirt n'Khellil (Tinerhir region, SE Morocco) - lost Devonian at the "Southern Variscan Front" [oral presentation]
}

\author{
Sven Hartenfels ${ }^{1}$, Marie-Kristin Rytina ${ }^{1}$ \& R. Thomas Becker ${ }^{1}$ \\ ${ }^{1}$ Westfälische Wilhelms-Universität Münster, Institut für Geologie und Paläontologie, Münster, Germany; \\ E-mail: sharten@@uni-muenster.de
}


The Tinerhir region of SE Morocco belongs to the southernmost part of the Variscides. At the northwestern margin of the stable Gondwana Craton, a steep palaeoslope must have formed, which received olistostromes with Silurian to Devonian clasts during an interval of block faulting (Eovariscan uplift; top UD IV to Upper Tournaisian), with massive erosion on adjacent uplifted areas (Rytina et al. 2013).

Intensive sampling provided for the first time in this region rich Famennian conodont faunas. Palaeogeographic clues come from the comparison of faunas and facies with the Meseta (Lazreq 1992, 1999) to the North and autochthonous Maider and Tafilalt (e.g. Hartenfels 2011) to the SE/ESE. Some clasts yielded diverse (up to 17 taxa) and partly new conodont assemblages for southern Morocco. The first record of Palmatolepis gracilis manca probably proves the gracilis manca (= Upper postera) Zone, which falls within the long ranging regional velifer-stabilis Interregnum of the Tafilalt/Maider. Known middle/upper Famennian faunas from the Meseta are less diverse despite their more tropic position.

\section{Enlightening lichens from Baltic amber [poster presentation]}

\section{Christoph Hartl $^{1}$, Carsten Gröhn ${ }^{2}$, Jochen Heinrichs ${ }^{3}$, Jouko Rikkinen ${ }^{4}$ \& Alexander R. Schmidt ${ }^{1}$}

${ }^{1}$ Georg-August-Universität Göttingen, Courant Research Centre Geobiology, Göttingen, Germany;

E-mails: christoph_hartl@stud.uni-goettingen.de \& alexander.schmidt@geo.uni-goettingen.de

2Glinde, Germany; E-mail:jcgroebn@t-online.de

${ }^{3}$ Ludwig-Maximilians-Universität München, Department für Biologie, Systematische Botanik und Mykologie, München, Germany; E-mail:jheinrichs@lmu.de

${ }^{4}$ University of Helsinki, Department of Biosciences, Helsinki, Finland; E-mail:jrikkine@mappi.belsinki.fi

The fossil record of lichens is very poor, and among the reported finds many are being disputed since they do not prove a real physiological interaction between a mycobiont (a fungus) and a photobiont (a photosynthesising organism like an eukaryotic alga), nor a distinctive body plan. Enlightening amber inclusions has become a very important part in the struggle to trace the evolution and palaeoecology of lichens. We applied light microscopy, scanning electron microscopy (SEM), and energy dispersive x-ray spectroscopy (EDX) to recently discovered macrolichens from Baltic amber. One specimen could be assigned to the genus Parmotrema (Lecanorales, Parmeliaceae) due to its very well-preserved apothecium and cortical structures. Another inclusion is assigned to the Physciaceae with affinities to the genera Physcia or Heterodermia. SEM of this specimen revealed a photobiont layer with microalgae and contacting hyphae as well as crystallized lichen acids. EDX uncovered additional crystals of halite and pyrite inside the specimen that were probably formed during and after redeposition of the amber into marine sediments. 


\title{
Geometric morphometric analysis of Middle Eocene crocodylians from Geiseltal, Sachsen-Anhalt (Germany) [oral presentation]
}

\author{
Alexander K. Hastings ${ }^{1}$ \\ ${ }^{1}$ Martin-Luther-Universität Halle-Wittenberg, Geiseltalmuseum, Halle/Sa., Germany; \\ E-mail:alexander.hastings@zns.uni-halle.de
}

The Geiseltal fossil collection from southern Sachsen-Anhalt includes remarkably well-preserved fossils of Middle Eocene age. These include well-preserved crocodylian skulls, representing at least four different genera. As sites with this many crocodylian genera are mostly unknown in modern systems, it has been hypothesized that these crocodylians may have differences in habit apart from living crocodylians. In order to test for similarity to known crocodylians, an analysis was conducted using geometric morphometrics to quantify shape in crocodylian skulls of all living species $(n=218)$ and all well-preserved crocodylian skulls of the Geiseltal fauna $(n=29)$. A relative warps analysis was used to plot out morphospace, revealing the Geiseltal fauna to be surprisingly distinct from all extant crocodylians. The only genus with an overlap in morphospace was the fossil taxon Asiatosuchus, which overlapped with extant Crocodylus. All 3 of the other genera occupied the new morphospace entirely. This analysis reveals quantitative evidence for the dissimilarity of the Geiseltal crocodylians from any modern environment where multiple crocodylian genera live.

\section{Modern light-based documentation techniques in palaeontology [keynote presentation] \\ Joachim T. Haug ${ }^{1}$ \\ ${ }^{1}$ Ludwig-Maximilian University of Munich, Department Biology II, Planegg-Martinsried, Germany; \\ E-mail:Joachim.hang@palaeo-evo-devo.info}

Modern documentation methods in palaeontology comprise complex technologies, such as different types of tomography. Yet, the machines used for such a kind of documentation are often quite restricted in availability (location and time), so these methods can rarely be applied to large sample sizes.

Modern approaches have also improved more "classical" light-based documentation methods - different kinds of macro- and micro-photography - including three-dimensional documentation of various kinds. These methods have the advantage that they are low cost, can be applied to large sample sizes, and the necessary set-ups are transportable.

Digital improvements can be used to overcome typical limitations of these methods, limited depth of field and limited field of view. The limited depth of field can be overcome by software packages that combine the information of stacks of images (each "frame" in a different focal plane) into a single fully sharp image. 
Images of adjacent, slightly overlapping image details can be combined to a single large image, covering the entire information of a single specimen with high resolution. Combining both enhancements - "composite imaging" - produces fully sharp, giga-pixel sized images.

Fossils additionally often demand for enhancing the contrast against the matrix. Simple contrasting methods use cross-polarised light and fluorescence. Both methods can be applied in macro- and microphotography.

Usually, relief and three-dimensional structure of fossils is documented via lowangle illumination. Yet, this method can produce severe artifacts. Unambiguous three-dimensional documentation methods range from "classical" stereo-imaging over multi-angle imaging to computer-based surface reconstructions via depthfrom-defocus or structure-from-motion algorithms.

With all these methods, there is a wide range of up-to-date imaging methods that enhance the details that can be extracted from a fossil and allow the construction of "virtual specimens".

\title{
New insights into concretion formation and fossil preservation in the Cretaceous Santana Lagerstätte [oral presentation]
}

Ulrich Heimhofer $^{1}$, Patrick Meister ${ }^{2}$, Stefano M. Bernasconi ${ }^{3}$, Daniel Ariztegui $^{4}$, David M. Martill ${ }^{5}$ \& Lorenz Schwark ${ }^{6}$

\author{
${ }^{1}$ Leibniz University, Institute for Geology, Hannover, Germany; E-mail: heimhofer@geowi.uni-hannover.de \\ ${ }^{2}$ Max Planck Institute for Marine Microbiology, Department of Biogeochemistry, Bremen, Germany \\ ${ }^{3}$ Swiss Federal Institute of Technology (ETH) Zurich, Department of Earth Sciences, Zurich, Switzerland \\ ${ }^{4}$ University of Geneva, Section of Earth \& Environmental Sciences, Geneva, Switzerland \\ ${ }^{5}$ University of Portsmouth, School of Earth and Environmental Sciences, Portsmouth, U.K. \\ ${ }^{6}$ Christian-Albrechts University, Institute of Geosciences, Kiel, Germany
}

Exceptional three-dimensional fossil preservation (incl. soft-tissue phosphatezation) within organic carbon-rich mudstones is often associated with the formation of a protective carbonate concretion. We used state-of-the-art geochemical tools to understand the biogeochemical processes during concretion growth in the case of the well-preserved fishes in the Early Cretaceous Santana Formation (Brazil). Differential compaction clearly suggests early precipitation of micrite surrounding a central cavity containing the decomposing fossil. The presence of pyrite and isotopically light carbonate indicates intense sulphate reduction (SR), including the production of ammonium from proteins to increase alkalinity and induce carbonate precipitation. The lack of pyrite and depleted Fe contents in the interior part of the concretion indicate absence of SR and possibly local onset of methanogenesis. Outward diffusing methane then was anaerobically oxidized in the surrounding SR zone. Furthermore, clumped isotopes allowed distinguishing an early micrite phase from two phases of late diagenetic overprint. Results from the Santana concretions reveal how new geochemical tools in combination with a 
better understanding of early diagenetic processes advance our understanding of fossil preservation in the geological record.

\section{Early Triassic microbialites on the margins of the Neotethys [posterpresentation]}

Katrin Heindel ${ }^{1}$, Daniel Birgel ${ }^{1}$, Sylvain Richoz ${ }^{2}$, Rainer Brandner ${ }^{3}$, Aymon Baud $^{4}$, Leo Krystyn ${ }^{5}$, Micha Horacek ${ }^{6}$, Taybeh Mohtat ${ }^{7}$, Erdal Koşun ${ }^{8}$ \& Jörn Peckmann $^{1}$

${ }^{1}$ University of Vienna, Department of Geodynamics and Sedimentology, Vienna, Austria;

E-mail:joern.peckmann@univie.ac.at

${ }^{2}$ Karl-Franzens University, Austrian Academy of Science, Graz, Austria

${ }^{3}$ Leopold-Franzens University, Institute of Geology and Palaeontology, Innsbruck, Austria

${ }^{4}$ Lausanne, Switzerland

${ }^{5}$ University of Vienna, Department of Palaeontology, Vienna, Austria

${ }^{6}$ HBLF A Francisco Josephinum, Wieselburg, Austria

${ }^{7}$ Geological Survey of Iran, Tehran, Iran

8 Akdeniz University, Department of Geological Engineering, Antalya, Turkey

After the severe end-Permian mass extinction, the Paleozoic skeletal carbonate factory was replaced by microbial carbonate production, resulting in widespread microbialites, including reefs that covered extensive areas on the Early Triassic ocean margins. Despite intensive research, the causes and modes of microbialite formation are insufficiently understood. In order to better constrain the benthic microbial communities and the formation mechanisms of Early Triassic microbialites, well preserved rocks from Iran and Turkey were studied. Some of the microbialites were found to contain abundant $n$-heptadecane, representing input from cyanobacteria. Other microbial fossils recognized are pseudohomologue series of head-to-tail linked $\mathrm{C}_{21}$ to $\mathrm{C}_{25}$ isoprenoids, likely deriving from halophilic archaea. Molecular fossils of anoxygenic phototrophs (farnesane, isorenieratane) and sulfate-reducing bacteria (iso-/anteiso- $\mathrm{C}_{15}$ and $\mathrm{C}_{17}$ alkanes) have been found as well. The clotted and peloidal microfabric and $\delta^{13} \mathrm{C}$ values of the microbial carbonates are in accord with a flourishing benthic population of prokaryotes on the Early Triassic seafloor.

\section{Evolution of seed-free land plants in the late Mesozoic and \\ Cenozoic [keynote presentation]}

Jochen Heinrichs ${ }^{1}$

'Ludwig-Maximilian University, Systematic Botany and Mycology, Munich, Germany;

E-mail:jheinrichs@lmu.de 
Seed-free land plants date back to the early Paleozoic; however, their extant diversity is considerably younger and originates in the late Mesozoic and Cenozoic.

In this presentation, I emphasize the necessity of combining information from DNA sequence variation of extant species and the fossil record in attempts at reconstructing the evolutionary history of bryophytes and pteridophytes. I introduce new fossils and demonstrate how they challenge previous hypotheses on divergence times of these plants. Special attention is given to the Cretaceous rise of the angiosperms and its possible influence on epiphytic clades of seed-free land plants.

\title{
A Lower Devonian trilobite fauna from a Carboniferous olistostrome at Taourirt n'Khellil (Tinerhir region, SE Morocco) [oral presentation]
}

\author{
Stephan Helling ${ }^{1}$ \& R. Thomas Becker ${ }^{1}$ \\ ${ }^{1}$ Westfälische Wilhelms-Universität Münster, Institut für Geologie und Paläontologie, Münster, Germany; \\ E-mail:stephanbelling@uni-muenster.de
}

The locality Taourirt n'Khellil exposes a thick olistostrome with small to housesized olistoliths ranging from Ordovician quartzites to Upper Devonian pelagic limestones (for overview see Hartenfels et al., this abstract volume). Light grey to grey, coarse-grained crinoid limestone with a sparitic matrix and abundant trilobites represents one of 25 different lithologies within the conglomerate. The diverse trilobite fauna comprises: Reedops maurulus Alberti, 1970, Cheirurus (Crotalocephalina) gibbus auster Alberti, 1970, Pragoproetus tafilaltensis (Alberti, 1964), Eremiproetus meridianomaurus Alberti, 1967, Eremiproetus? sp., Bojoscutellum aff. tiddasense (Alberti, 1970), Belenopyge sp., as well as odontopleurid remains.

The Taourirt n'Khellil trilobite assemblage is clearly of Pragian age. It combines faunal elements of the Tafilalt (SE Anti-Atlas) and of the northern Meseta, as it can be expected from the intermediate position of the locality at the southern margin of the Variscides. Additional material is necessary to clarify open taxonomic questions, such as the affinities of the odontopleurids.

\section{Upper Cenomanian Burgundid stromatoporoids from Morocco [posterpresentation]}

\author{
Hans-Georg Herbig ${ }^{1} \&$ Johanna Hitz ${ }^{1}$ \\ ${ }^{1}$ University of Cologne, Institute of Geology and Mineralogy, Cologne, Germany; \\ E-mails:berbig.paleont@uni-koeln.de@ hanna.hit_@googlemail.com
}

In Cretaceous times, coral-stromatoporoid-rudist communities were widespread on Tethyan platforms. In spite of that, Mesozoic stromatoporids - in general - are faintly known. We studied burgundid stromatoporoids, which were sampled during 
a reconaissance study of the late Cenomanian-Turonian carbonate sequences in southern and eastern Morocco. They have ben derived from Upper Cenomanian reefal to perireefal, rudist-bearing environments from the well-known Akerbouss section (Errachidia-Boudenib-Erfoud basin, Preafrican platform) and from equivalent strata NE of Anoual (Jbel Dir el Abiod, SW Hauts Plateaux).

The apparently monospecific fauna comprises fingerlike, mostly 15-35 mm thick, cylindrical specimens that show a central reticulate zone, and an outer extremely regular lamellar zone with vertically arranged, straight pillars, limited to one interlamellar space. The central zone comprises $1 / 4$ to $1 / 3$ of the total diameter. Astrorhizal systems are sparse. The existence of spiculae within the dark median line of the fibrous walls remains equivocal. Our specimens seem to be the youngest representatives of the family Burgundidae, which hitherto was known from the Late Jurassic and Lower Cretaceous (Upper Oxfordian-Hauterivian). The studied localities mark approximately the westernmost occurrences of Upper Cenomanian stromatoporoids on the southern Tethyan platforms. They are neither known from the Middle Atlas and the adjacent Haute Moulouya nor further west from the High Atlas and the Moroccan Atlantic coastal basins, i.e. the Essaouira basin.

\title{
A calcimicrobe-archaeocyathid boundstone from Central Europe - First proof of Lower Cambrian in the Saxothuringian Zone of northeastern Bavaria (Germany) [poster presentation]
}

\author{
Hans-Georg Herbig ${ }^{1}$, Thomas Wotte ${ }^{1} \&$ Stefanie Becker ${ }^{1}$ \\ ${ }^{1}$ University of Cologne, Institute of Geology and Mineralogy, Cologne, Germany; \\ E-mails:berbig.paleon@@uni-koeln.de; thomas.wotte@uni-koeln.de soplusminus@web.de
}

Middle Cambrian siliciclastic strata have been known since decades from northeastern Bavaria (Franconian Forest, Saxothuringian Zone, Germany). The recent find of a calcimicrobe-archaeocyathid boundstone now proves the existence of the Lower Cambrian. Besides comparable facies from a subcrop of the Saxothuringian Zone in the vicinity of Leipzig (Saxonia, Doberlug-Torgau-Delitzsch syncline), this is the second proof of archaeocyathid-bearing limestones from Central Europe.

The observed boundstone has been derived from a several meters long slide block within the late Middle Viséan/early Late Viséan "Heinersreuth Blockkonglomerat" from the Carboniferous wildflysch of the Bavarian facies realm. The conglomerate consists of differentiated lithotypes, reworking a variegated suite of Cambrian to Carboniferous sedimentary rocks. The boundstone is characterised by a recrystallised sparitic matrix with some angular detrital quartz grains and xenomorphic, late diagenetic dolomite crystals. Irregular archaeocyathids and Girvanella are associated. Girvanella colonies are often strongly micritised into spongiostromatic masses. Frequently, they form stacked mats which are rarely incrusted by 
bubble-like microproblematica. The boundstone originated on shallow platform environments of low- to mid-latitude and stresses palaeogeographic relations with the western Perigondwana realm, where similar facies are known from Sardinia, Sierra Morena (SW Spain), and Morocco.

Ecosystem evolution of Lake Sihetun: A multiproxy approach to the Early Cretaceous Liaoning Fossil Lagerstätte (China) [oral presentation]

\author{
Manja Hethke ${ }^{1}$, Franz T. Fürsich ${ }^{1} \&$ Jiang Baoyu $^{2}$ \\ 'Friedrich-Alexander University Erlangen-Nürnberg, Geo-Center of Northern Bavaria, Erlangen, Germany; \\ E-mails:manja.hethke@fau.de \& fran:fuersich@fau.de \\ ${ }^{2}$ Nanjing University, State Key Laboratory for Mineral Deposits Research, School of Earth Sciences and Engineering, \\ Nanjing, P. R. of China; E-mail: byjiang@nju.edu.cn
}

Deposits of Lake Sihetun of the volcanic Yixian Formation (Barremian-Aptian) document a unique time slice, during which major clades diversified. Whereas previous work centred on groups such as feathered dinosaurs and early birds, little is known about the evolution of the lake's ecosystem. Inadequate knowledge and oversimplification of the ecology of clam shrimps, the most abundant faunal component, have hampered palaeoenvironmental interpretations. A multiproxy approach was employed to identify the trajectory of the lake ecosystem, using microfacies analysis, biomineralization studies, and geometric morphometrics of clam shrimps. Studies were designed to delimit the major physicochemical processes that shaped the lake before checking them against features observed in palaeocommunity successions. Four well-defined developmental phases have been identified for Lake Sihetun, with later phases characterized by increased siltation and oxygen availability within the hypolimnion. Diverse biotic reactions to palaeoenvironmental changes are discussed along with the constraints each phase posed on fossil preservation, exemplified by studies of clam-shrimp biomineralization.

\title{
Comparison of age stages and wear facets at the molars of fossil and extant bats (Mammalia: Chiroptera) [oral presentation]
}

\author{
Romina Christin Hielscher ${ }^{1}$, Julia A. Schultz ${ }^{1}$ \& Thomas Martin ${ }^{1}$ \\ ${ }^{1}$ Rheinische Friedrich-Wilhelms-Universität, Steinmann-Institut für Geologie, Mineralogie und Paläontologie, Bonn, \\ Germany; E-mail: Romina.Hielscher@uni-bonn.de
}

Bats are the second-largest order within the Mammalia, with over 1100 extant species. Different feeding strategies are reflected in the dentition and wear facets. Insectivorous bats, retaining the primitive feeding strategy, have a modified form of the tribosphenic molar as many other insectivorous mammals. On the basis of dentine exposure at the molar surfaces, six wear stages were defined for the extant 
Pipistrellus pipistrellus and four for the extinct Pseudorbinolophus antiquns. The wear stages of $P$. antiquns can be roughly compared to stages 3-6 of $P$. pipistrellus. The molars of both species show wear facets with striations that follow two directions and indicate a bucco-lingually directed two-phased masticatory movement. The striations become less strongly directed in later stages. Shear-cutting dominates the mastication process in the early wear stages, whereas in later stages, the crushing component increases due to continued wear and subsequent loss of structure. Furthermore, the average age of the studied P. pipistrellus-population determined from the wear stages is considerably younger than that found within the fossil P. antiquus-assemblage.

\title{
Testing for phylogenetic niche conservatism in the fossil record of rhineurids (Amphisbaenia) [oral presentation]
}

\author{
Christy A. Hipsley ${ }^{1} \&$ Johannes Müller $^{1}$ \\ ${ }^{1}$ Museum für Naturkunde, Leibniz-Institut für Evolutions- und Biodiversitätsforschung, Berlin, Germany; \\ E-mails:Christy.Hipsley@mfn-berlin.de \& Johannes.Mueller@mfn-berlin.de
}

Rhineurid amphisbaenians are represented by a single living species restricted to the Florida Peninsula, despite a rich Cenozoic fossil record in North America. Such relict endemism may be the result of phylogenetic niche conservatism (PNC), the retention of ancestral traits preventing niche expansion. To test if PNC limits the distribution of Rhineura floridana, we compare its current environmental preferences (temperature, precipitation, soil) to paleoenvironmental data from the fossil record. We find no evidence of PNC in modern R. floridana, as it also endured drier glacial periods in Florida. Ancient rhineurids also exhibit wide climatic tolerances, shifting from subtropical-humid to semi-arid savanna conditions during the Eocene-Oligocene transition. Rhineurids nearly disappear from North America following the mid-Miocene Climatic Optimum, potentially due to the onset of prolonged freezing temperatures in their western range. This limitation could be interpreted as PNC for the entire family, but also characterizes much of Amphisbaenia, emphasizing the relevance of the temporal as well as phylogenetic scale at which PNC is investigated.

\section{The evolution of brood care behavior in dictyopteran insects and its fossil record [poster presentation] \\ Marie K. Hörnig ${ }^{1}$, Andy Sombke ${ }^{1}$, Carolin Haug $^{2}$ \& Joachim T. Haug ${ }^{2}$ \\ ${ }^{1}$ Ernst-Moritz-Arndt University, Zoological Institute and Museum, Cytology and Evolutionary Biology, Greifswald, Germany; E-mail: Marie.Hoernig@gmx.net \\ ${ }^{2}$ Ludwig-Maximilian University, Department Biology II, Planegg-Martinsried, Germany}


Dictyoptera is a group of insects, represented by three morphotypes: cockroaches, mantids, and termites. Early 'roachid' dictyopterans are among the dominant faunal elements in Carboniferous forests, but dictyopterans can also be found in younger deposits, e.g., in the Cretaceous Crato formation, or in Baltic amber. Modern dictyopterans exhibit a wide range of brood care adaptations: carrying an ootheca, ovovivipary and feeding of young, or sub-social and even eu-social behaviour. The fossil record can provide important additional data for reconstructing the evolution of morphological traits, but rarely does so for the evolution of behavioural aspects.

We present examples of cases in which fossils provide direct or indirect evidence of brood care in Dictyoptera. Cockroach nymphs preserved in 50 million years old amber indicate further reaching brood care behaviour: aggregations of blind hatchlings demonstrate a dependence on the parents in early stages. These examples can be integrated into a more holistic approach to the understanding of the evolution of brood care within Dictyoptera.

\section{CONCH - a newly developed software to improve the quantitative morphological approach for spiral shells [oral presentation]}

\section{René Hoffmann ${ }^{1}$ \& Peter Göddertz ${ }^{2}$}

${ }^{1} \mathrm{R} u b$-Universität, Institut für Geologie, Mineralogie und Geophysik, Bochum, Germany;

E-mail: Rene.Hoffmann@rub.de

${ }^{2}$ Rheinische Friedrich-Wilhelms-Universität, Steinmann-Institut für Geologie, Mineralogie und Paläontologie, Bonn, Germany

Species description in palaeontology is based on the morphology of preserved hard parts.

So far, species were usually differentiated from each other utilizing a static ("Linnean") rather than a dynamic ("Darwinian") approach. This static method does not account for intraspecific variation, co-variation, and ontogenetic changes. Many species were thus validated on the grounds of subtle morphological differences of the adult stage. Quantitative studies of fossil species, e.g. ammonites, have improved our understanding and the way of species description, documenting a wide intraspecific variability in conch parameters and ornamentation. However, quantitative studies are often hampered for three reasons: limited number of fossils, well preserved material, and it is a time-consuming process. Here we present newly developed software which significantly reduces the amount of time necessary to measure standard distances for spirally coiled shells, i.e. diameter, whorl height, whorl width, whorl interspace, umbilical width, and ornamentation. Our software therefore allows for a more accurate data-mesh to trace ontogenetic changes more precisely. 


\title{
The curious case of the Early Triassic [oral presentation]
}

\author{
Richard Hofmann ${ }^{1}$
}

${ }^{1}$ University of Zurich, Palaeontological Institute and Museum, Zurich, Switzerland;
E-mail: richard.hofmann@pim.ugh.ch

Following the end-Permian mass extinction, the Early Triassic time interval represents an important deep-time test case to address key questions of evolutionary biology and earth system science: how do ecosystems respond to large-scale environmental stress, how quickly do ecosystems recover, and how do evolutionary processes operate under the unusual conditions of vacated ecospace? Since the recovery appears to have been protracted, it is traditionally suggested that it was largely controlled by extrinsic factors such as persistent environmental stress. Alternatively, the drastic reduction of biodiversity and ecosystem complexity might have been so detrimental that the long recovery period reflects intrinsically triggered features of post-extinction communities. Quantitative benthic palaeoecology was used to track the ecological and environmental conditions throughout the recovery interval of the palaeo-tropics to assess the role of extrinsic and intrinsic constraints on the ecological and taxonomic restoration.

The data presented support a "multiple crises" scenario. Recovery signals occur during the late Griesbachian and the early Spathian. Periods of ecological decline are represented by the late Dienieran and possibly the late Smithian. This pattern suggests that ecosystems suffered from short but discrete periods of environmental stress rather than long-term deterioration. It is also proposed that the low alpha diversity of the immediate extinction aftermath expresses at foremost the consequence of the extinction and not necessarily environmental stress. Similarly, the poor taxonomic differentiation (low beta diversity) of ecosystems might have resulted from a low competitive ecological environment during the Early Triassic. The absence of species that are specialized to certain conditions allowed surviving species to thrive outside their individual ecological optima. This effect would also explain the delayed adaptive radiation of surviving clades, which took place after diffuse competition increased by the immigration of species and few autochthonous speciation events.

The analyses of ichnological data has shown that bioturbation was extremely reduced during the Early Triassic. Although this fact was recognized relatively early, its consequences to marine sediments and benthic ecosystems have not been addressed. As an alternative to the established notion championing environmental stress a cause, it is suggested that this was a primary result of the mass extinction. As biogenic sediment mixing is fundamental to geochemical cycling and ecosystem performance, its virtual absence was probably not only important in altering chemical pathways in marine sediments but it might have imposed a hitherto neglected constraint on the Early Triassic recovery.

Because of the dramatic defaunation caused by the end-Permian mass extinction, the Early Triassic represents a "curious" time interval during which evolu- 
tionary and ecological processes operated markedly differently when compared to "normal" background times.

\title{
A high-resolution angiosperm pollen record covering Early to Late Albian mid-latitude coastal deposits (Lusitanian Basin, Portugal) [oral presentation]

\author{
Maurits Horikx ${ }^{1}$, Jorge L. Dinis ${ }^{2} \&$ Ulrich Heimhofer ${ }^{1}$ \\ 'Leibniz University, Institute for Geology, Hannover, Germany; E-mail: horikx@geowi.uni-hannover.de \\ ${ }^{2}$ Universidade de Coimbra, Departmento de Ciências da Terra, Coimbra, Portugal
}

In this study, a high-resolution Early to Late Albian pollen record from a thick $(\sim 190 \mathrm{~m})$ coastal succession in the Lusitanian Basin containing mixed carbonate, clay and siliciclastic near-shore deposits is presented. Dating of the outcrop was obtained via Sr- and C-isotope stratigraphy together with dinoflagellate cyst biostratigraphy. The proximal depositional setting and high sedimentation rate of the São Julião outcrop provides distinct radiation patterns and a wealth of previously not described angiosperm pollen types. The palynological record also shows significant changes in the accompanying palynoflora. The palynological results indicate a warm and dry climate during most of the Albian. Angiosperm pollen is only a minor component in the palynoflora record and ranges between 5-30\%. Monoaperturate grains of magnoliid affinity (Asteropollis, Retimonocolpites, Clavatipollenites), are the most dominant angiosperm pollen type, both in abundances and diversity. (Reti-)tricolpate, tricolporate and zonoaperturate pollen grains are also present. The occurrence of several odd-shaped angiosperm Dichastopollenites pollen types is intriguing. In conclusion, we present the first high resolution angiosperm pollen record from the Albian in Europe, in particular the long lasting Late Albian.

\section{The Berriasian-Early Valanginian (Early Cretaceous) archosaur fauna of northwestern Germany - insights into composition, palaeo- ecology and palaeobiogeographical relationships [oral presentation]}

\author{
Jahn J. Hornung ${ }^{1}$ \\ ${ }^{1}$ Georg-August University Göttingen, Geoscience Centre, Department of Geobiology, Göttingen, Germany; \\ E-mail:jhornun@gwdg.de
}

The archosaur fauna of the Berriasian to earliest Valanginian Bückeberg Formation (a.k.a. northwestern "German Wealden") of northwestern Germany is represented by abundant (dinosaur) tracks, as well as by skeletal material. Faunal components include crocodilians (goniopholidids, pholidosaurids, atoposaurids), dinosaurs (theropods, sauropods, ankylosaurs, ornithopods, probably basal ceratopsians), and pterosaurs. Deposited in a predominantly limnic palaeoenvironment, dinosaur 
ichnocoenoses evidence a diverse theropod assemblage and an iguanodontian ornithopod dominated herbivorous dinosaur community in deltaic and floodplain lowlands, while sauropods, ankylosaurs and basal ceratopsian were rare in these environments and possibly more abundant in hinterland/upland areas. Goniopholidid and pholidosaurid crocodilians were abundant in near-shore lacustrine and fluvial settings, but atoposaurids were very rare and possibly more terrestrial. The pterosaur remains are largely undiagnostic, but ichnological evidence shows the presence of taxa with wing-spans up to $6 \mathrm{~m}$. The fauna includes mostly groups which could be traced back to Jurassic European/Pangean ancestors, though some elements may support East Asian/Laurasian affinities (basal ceratopsians, possibly troodontids).

Sauropterygian fossils from the predominantly limnic-brackish Bückeberg Formation (Berriasian-Early Valanginian, Early Cretaceous) of northwestern Germany - diversity, distribution, and palaeoecology [posterpresentation]

\author{
Jahn J. Hornung ${ }^{1}$, Sven Sachs ${ }^{2} \&$ Benjamin P. Kear ${ }^{3}$ \\ ${ }^{1}$ Georg-August University Göttingen, Geoscience Centre, Department of Geobiology, Göttingen, Germany; \\ E-mail:jhornun@gwdg.de \\ ${ }^{2}$ Engelskirchen, Germany; E-mail: Sachs.Pal@gmx.de \\ ${ }^{3}$ University of Uppsala, Department of Earth Sciences, Palaeobiology Programme, Uppsala, Sweden; \\ E-mail:Benjamin.kear@geo.uu.se
}

The Bückeberg Formation (Lower Saxony Basin, northern Germany and eastern Netherlands) represents a siliciclastic succession, deposited during the midBerriasian through to the earliest Valanginian. The unit is predominantly lacustrine with fluvial inflow and episodic marine connections to the Boreal Sea. Its fossil faunas include sauropterygian remains comprising isolated bones and partial, articulated skeletons. Though most of these finds cannot be identified at genus level, there is evidence of at least three morphotypes, representing distinct taxa: "Plesiosaurus degenhardti" Koken, 1887; Brancasaurus brancai Wegner, 1914; and an unnamed "pliosauromorph". Other previously named taxa are dubious and/or may be synonymous. Articulated remains are concentrated to two abundance maxi$\mathrm{ma}$ in the Bückeberg Formation: the Obernkirchen Sandstone (lower Bückeberg Fm.) and Osterwald Mbr. (upper Bückeberg Fm.). The depositional environments of the former succession comprise freshwater lacustrine-deltaic barrier and mouthbar sandstones, and brackish deep-water pelites and littoral marls/calcarenites in the latter. The largely complete skeletons of B. brancai originate from a deep-water Konservat-Lagerstätte formed under brackish, euxinic conditions. These individuals are osteologically immature, which accords with other occurrences of limnic plesiosaurs and might infer ontogenetically controlled, migratorial behaviour. 
Paleobiology and paleoecology of the early Turonian (Late Cretaceous) ammonite Pseudaspidoceras flexuosum [poster presentation]

\author{
Christina Ifrim ${ }^{1}$ \\ ${ }^{1}$ Ruprecht-Karls-Universität, Institut für Geowissenschaften, Heidelberg, Germany; \\ E-mail: Christina.Ifrim@geow.uni-heidelberg.de
}

The Pseudaspidoceras flexuosum was a common early Turonian ammonite. 160 specimens from the Vallecillo section, NE Mexico section, allow for quantitative analyses in combination with sedimentology and geochemistry and thus insight into ammonoid paleobiology and paleoecology. P. flexuosum dwelled in the welloxygenated upper surface water as part of the open marine pelagic ecosystem; a demersal mode of life is excluded. Changes in abundance and diameter appear to be related to changes of oxygen content in the water column. Dimorphism is expressed in size and less in ornamentation. The function of the long, fragile spines of both dimorphs can be explained. The differentiated model of the mode of life of $P$. flexuosum contrasts with the paleoecology reconstructed for other ammonites. Ammonites covered a wide range of ecological niches, and their complex paleoecology will only be solved with more species-based analyses.

\title{
Inoceramids and biozonation in the El Rosario section, Coahuila, northeastern Mexico: a potential Global Stratotype Section and Point for the Turonian-Coniacian boundary (Upper Cretaceous) [oral presentation]

\author{
Christina Ifrim ${ }^{1}$, Frank Wiese ${ }^{2} \&$ Wolfgang Stinnesbeck ${ }^{1}$ \\ ${ }^{1}$ Ruprecht-Karls-Universität, Institut für Geowissenschaften, Heidelberg, Germany; \\ E-mail:Christina.Ifrim@geow.uni-beidelberg.de \\ ${ }^{2}$ Georg-August-Universität, Geowissenschaftliches Zentrum, Abteilung Geobiologie, Göttingen, Germany
}

The Rosario section in northeastern Mexico contains a complete record of sediment across the Turonian-Coniacian boundary (TCB). Thirteen inoceramid taxa were hitherto identified. They provide a fine zonation across the TuronianConiacian boundary. Most inoceramid zones are well represented in Rosario and expanded compared to other sections. Ammonites are rare, mostly endemic and provide a low resolution across the TCB than inoceramids. The Rosario section provides the most complete sedimentary and inoceramid record across the TCB known to date and thus bears a high potential to be used as a Global Boundary Stratotype Section and Point (GSSP) for the base of the Coniacian. All requirements for that are complied with at El Rosario. 


\title{
Reinvestigation of the postcranial skeleton of Henkelotherium guimarotae (Cladotheria, Mammalia) from the Late Jurassic of Portu- gal using MicroCT data [oral presentation]
}

\author{
Kai Jäger ${ }^{1}$, Luo Zhexi $\&$ Thomas Martin ${ }^{1}$ \\ ${ }^{1}$ Rheinische Friedrich-Wilhelms University, Steinmann Institute of Mineralogy, Geology and Palaeontology, Bonn, \\ Germany; E-mail:jaeger.kai@gmx.net \\ ${ }^{2}$ University of Chicago, Department of Organismal Biology and Anatomy, Chicago, Illinois, U.S.A.
}

The Jurassic dryolestoid Henkelotherium guimarotae is known by a largely complete skeleton. Although the postcranium has been previously described, several elements covered by matrix were inaccessible. We present new insights using x-ray computed tomography $(\mu \mathrm{CT})$. Contrary to earlier description, Henkelotherium has a more plesiomorphic humerus similar to that of Dryolestes leiriensis with clearly separated radial and ulnar condyles on the anterior side and incipient trochlea on the posterior side of the distal end. The scapula is also more plesiomorphic than previously assumed, revealing a laterally flared rim on the posterior border of the scapula, with similarities to symmetrodontans such as Zhangheotherium. Several characters of hind limb and pelvis (e.g. the absence of a parafibular process, a slender femur with a long neck, slightly asymetrical distal femoral condyles) suggest a more derived posture, closer to that of Didelphis than to extant monotremes. The length/width ratio of the caudal vertebrae is similar to extant arboreal mammals. Our new study has corroborated a previous hypothesis that Henkelotherium had an arboreal lifestyle.

\section{D reconstruction of a basal therapsid skull - combining modern and conventional methods for 3D retro-deformation [poster presentation]}

\author{
Maren Jansen ${ }^{1}$, Robert R. Reisz ${ }^{2}$, Christian F. Kammerer ${ }^{1}$ \& Jörg Fröbisch ${ }^{1}$ \\ ${ }^{1}$ Humboldt-Universität, Museum für Naturkunde, Leibniz-Institut für Evolutions- und Biodiversitätsforschung, \\ Berlin, Germany; E-mails: maren.jansen@mfn-berlin.de; christian.kammeren@mfn-berlin.de_o joerg.froebisch@mfn- \\ berlin.de \\ ${ }^{2}$ University of Toronto, Department of Biology, Mississanga, Ontario, Canada; E-mail: robert.reisz@@utoronto.ca
}

The Mezen fauna (Roadian/Wordian) of northern European Russia yields one of the most basal known therapsid faunas, including the enigmatic and poorly known genera Alrausucbus, Niaftasucbus, Nikkasaurus, and Reiszia. The former two are dinocephalian therapsids, which occupied a wide range of ecological niches and dominated terrestrial ecosystems during the Middle Permian. For the present study, we investigated a new, well-preserved, but crushed dinocephalian skull from Mezen via $3 \mathrm{D}$ computed tomography (micro-CT) and a detailed retro-deformed reconstruction. The CT-data was combined with the external morphological data for an exhaustive reconstruction of all preserved individual skull elements. The results 
were then utilized for a 3D retro-deformation using the wax plate reconstruction technique. The combination of these modern and conventional methods provides the most accurate retro-deformed model for an unknown taxon. In addition, the inclusion of the new skull in a comprehensive phylogeny of early therapsids indicates that it is the most basal known anteosaurian dinocephalian and gives new insights into the relationships of basal therapsids.

\title{
Mesozoic non-rigid hexactinellid sponges - a rarity or overlooked ? Known and new fossils from the Late Cretaceous of Northern Germany and Denmark [oralpresentation]
}

\author{
Dorte Janussen ${ }^{1}$, Norbert Hauschke ${ }^{2}$, Michael Laaß ${ }^{3,4}$ \& Corinna Hoff ${ }^{5}$ \\ ${ }^{1}$ Forschungsinstitut und Naturmuseum Senckenberg, Frankfurt/M., Germany; \\ E-mail:dorte.janussen@senckenberg.de \\ ${ }^{2}$ Martin-Luther-Universität Halle-Wittenberg, Institut für Geowissenschaften und Geographie, Halle/S., Germany; \\ E-mail:norbert.bauschke@geo.uni-halle.de \\ 3 Staatliches Museum für Naturkunde Karlsrube, Abteilung Geowissenschaften, Karlsrube, Germany; \\ E-mail:michael.laass@gmx.de \\ ${ }^{4}$ Ruprecht-Karls-Universität, Institut für Geowissenschaften, Heidelberg, Germany \\ ${ }^{5}$ GONOMETRICS, Halle/Sa., Germany; E-mail: hoff@gonometrics.de
}

The Late Cretaceous was a blooming period of the sponge class Hexactinellida (glass sponges) worldwide. However, the large majority of the palaeontological literature has described the rigid hexactinellid taxa, whereas up to now the nonrigid Amphidiscophorida and Lyssacinosida, which are very diverse in the deep-sea today, are almost absent, although recent papers have documented some wellpreserved non-rigid hexactinellid sponges, including a mass occurrence in a "fossil window", the Coniacian Arnager Limestone on the isle of Bornholm. First investigations of the sponges from this unique locality in terms of preservation state and diversity of non-rigid Hexactinellida have proven for the first time the existence of many genera of the recent diverse order Lyssacinosida and sub-class Amphidiscophora in the fossil record. New findings of completely preserved fossil Hexactinellida, new species of the family Hyalonematidae, confirm the status of the Arnager Limestone as a unique window into the fossil record of the Porifera.

Other very fossiliferous sponge-localities, such as the Late Campanian of NW Germany, e.g. Höver and Misburg near Hannover, Münsterland Basin, have become famous mainly because of the extraordinarily rich record of rigid siliceous Demospongiae ("Lithistida") and Hexactinellida (Hexactinosida and Lychniscosida). Recent findings of common to abundant sponge fragments, particularly basal parts of Amphidiscophorida from Höver and Lyssacinosida from the Maastrichtian from Rügen, indicate a much higher diversity and wider distribution of these taxa in the Cretaceous than so far assumed according to their rare documentation. Entire Cambrian sponge fossils (e.g. Beresi \& Rigby 2013), which can probably be 
attributed to the Hyalonematidae, Amphidiscophorida, further confirm the hypothesis of a very long fossil history of these hexactinellid taxa.

\title{
Early Cambrian sponges from Sirius Passet, North Greenland [poster presentation]
}

\author{
Dorte Janussen ${ }^{1} \&$ Joachim Reitner ${ }^{2}$ \\ ${ }^{1}$ Forschungsinstitut und Naturmuseum Senckenberg, Frankfurt/M., Germany; \\ E-mail:dorte.janussen@senckenberg.de \\ ${ }^{2}$ Georg-August-Universität, Geowissenschaftliches Zentrum, Abteilung Geobiologie, Göttingen, Germany; \\ E-mail:jreitne@gwdg.de
}

Occurrences of Cambrian sponges in body preservation are tied to certain fossilization conditions and are thus relatively rare. In the Middle Cambrian, several such Lagerstätten are known, e.g. Burgess Shale (Canada) and Wheeler Shale (Utah, USA), where originally soft sponges in excellent body preservation were found. Here we give the first report on bodily preserved sponges from the Early Cambrian of Sirius Passet, North Greenland. These sponges were collected by John Peel and his group (University Uppsala, Sweden). The Sirius Passet site is part of the northern Peary Land and the fossiliferous rocks are found in the Transitional Buen Formation, Cambrian Series 2, Stage 3 (Peel \& Ineson 2011). The locality is famous for the occurrence of complete specimens of Halkeria evangelista, an early mollusk.

From Sirius Passet, we identified so far 7 genera: Choia (2 spp., 1 new), Choiaella (1 sp.), Prohalichondria (n. g., 1 sp.), Piraniella (n. g., 1 sp.), Allantospongia (1 sp.) (Demospongiae), and Hyalosinica (1 sp.) and Solactiniella (1 sp.), (Hexactinellida). Furthermore we found 2 unidentified sponge morphospecies.

The famous, Middle Cambrian Burgess Shale lagerstätte yields a rich and diverse Poriferan fauna, especially of the group Demospongiae. According to Rigby (1986), the Burgess Shale contains 15 genera of the Demospongiae, 3 genera of the Hexactinellida and 2 genera of the Calcarea. Compared to the rich Middle Cambrian localities, the herein described faunula from Sirius Passet appears rather poor. However, with 5 demospongid genera represented, this is one of the richest occurrences of Early Cambrian Demospongiae worldwide. Most other Early Cambrian Poriferan localities examined so far have provided mainly hexactinellid sponges. This is true especially for the Tommotian to Botomian Sansha and Chengiiang lagerstätten (Yunnan, China). In Sirius Passet, we found the first moderately diverse, Lower Cambrian sponge fauna, including 5 genera already known from the Middle Cambrian and 2 genera new to science. This is the first Lower Cambrian lagerstätte which shows a dominance of the class Demospongiae. 


\section{Highly diversified Chaohu Fauna (Olenekian, Early Triassic) and sequence of Triassic marine reptile faunas from South China [oral presentation]}

Ji Cheng ${ }^{1,2}$, Jiang Dayong ${ }^{2}$, Fu Wanlu², Ryosuke Motani ${ }^{3}$, Hao Weicheng 2 , Olivier Rieppel ${ }^{4}$, Andrea Tintori ${ }^{5}$, Sun Yuanlin ${ }^{2} \&$ Sun $\mathrm{Zuoyu}^{2}$

${ }^{1}$ Chinese Academy of Sciences, Nanjing Institute of Geology and Palaeontology, Nanjing, P. R. of Cbina; E-mail:jicheng04@126.com

2Peking University, Department of Geology and Geological Museum, Beijing, P. R. of China;

E-mail:djiang@pku.edu.cn

${ }^{3}$ University of California, Department of Geology, Davis, California, U.S.A.; E-mail: rmotani@ucdavis.edu

${ }^{4}$ The Field Museum, Department of Geology, Chicago, Illinois, U.S.A.; E-mail: orieppel@fieldmuseum.org

${ }^{5}$ Universita degli Studi di Milano, Dipartimento di Scienze della Terra, Milano, Italy;

E-mail: andrea.tintori@unimi.it

Mesozoic marine reptiles were the top predators of the marine ecosystem in the dinosaur age. They first appeared during the Early Triassic (latest Olenekian known before) after the end-Permian mass extinction, earlier than that of the dinosaurs on land which first appeared in the Late Triassic (Carnian). However, the fossil records of Mesozoic marine reptiles from the Lower Triassic are very rare, with only a single taxon usually being found from one locality, such as the ichthyopterygian Utatsusaurus from Miyagi of Japan and Chaobusaurus from Anhui of South China. Furthermore, the records of Early Triassic sauropterygian from South China and other localities are ambiguous.

During our excavation at Majiashan of Chaohu, Anhui Province from 2010 to 2012, plenty of new marine reptiles have been found, co-occurring with the basal ichthyopterygian Chaobusaurus from the Middle-Upper Member of the Nanlinghu Formation, with age of the Spathian of the Olenekian (Early Triassic). Eighty complete skeletons of Chaobusaurus were excavated, some of which were preserved three-dimensionally in nodules. Here we find more than one ichthyopterygian taxa, indicating that the ichthyosaur diversity is higher than we used to expect. From the layers above the typical Chaohusaurus levels, we found an articulated postcranial skeleton of a sauropterygian and a new and strange fossil which can be referred to diapsid. This is the first definite Early Triassic sauropterygian with exact stratigraphic data within the Spathian. The diapsid material is about $1.4 \mathrm{~m}$ long and can be easily distinguished from other marine reptiles by its remarkably small skull.

The new materials from Chaohu Fauna suggest that multiple clades of marine reptiles, including ichthyopterygian, sauropterygian, and a new clade of diapsid, have co-existed during the middle Spathian in the Early Triassic, earlier and more diversified than we previously believed. Here the Chaohu Fauna with exact stratigraphic control, along with other fossil remains from Yuan'an and Nanzhang of Hubei and Wuming of Guangxi, are the earliest records of Mesozoic marine reptile faunas known so far, along with the contemporaneous Grippia Fauna from arctic Spitsbergen, and the Utatsusaurus Fauna from Japan. It represents the end of the depressive stage and the beginning of the rapid radiation, from its macroscopical 
appearances occurring in the stage scale regressive course but on the period scale in the process of the global sea level rising.

During the last decades, three other diverse Triassic marine reptile faunas, younger than the Chaohu Fauna have been reported in Guizhou and Yunnan provinces (southwestern China), including: the Anisian (Middle Triassic) PanxianLuoping Mixosaurus panxianensis Fauna, the Ladinian (Middle Triassic) XingyiFuyuan Keichousaurus hui Fauna, and the Carnian (Late Triassic) Guanling Guizhouichthyosaurus-Xinpusaurus Fauna. The Anisian Panxian Fauna contains abundant marine reptiles and fishes associated with bivalves and brachiopods. More than ten marine reptile taxa were reported from the $1.82 \mathrm{~m}-2.10 \mathrm{~m}$ thick fossiliferous level in the Upper Member of Guanling Formation, including placodontia sauropterygian, pachypleurosauria sauropterygians, nothosaurid sauropterygians, one primitive ichthyopterygian and mixosaurid ichthyosaurs, archosaurs, protorosaurs, and saurosphargid. This diversified Middle Triassic marine reptile fauna shows strong western Tethyan paleobiogeographic affinity but is earlier than those Tethyan Anisian faunas known in Europe such as the Monte San Giorgio in central Europe and the Muschelkalk in Germanic Basin, and also earlier than those in North America such as the Nevada Fauna in USA. This has also been supported by the phylogenetic analyses of the ichthyosaurs and sauropterygians. Recent study on the phreatoicidean isopod fossils Protamphisopus baii from the Anisian Luoping Fauna, is close to Australian fresh water Protamphisopus wianamattensis, reveals a potential southward (Australian) invertebrate paleogeographic affinity. These Anisian marine reptile faunas have appeared as physical marker of the rapid recovery of the Triassic marine ecosystem.

The Xingyi Fauna has a wide geographic distribution and is characterized by the abundant small sized pachypleurosauria sauropterygian Keichousaurus, nothosaurid sauropterygians and pistosauroid sauropterygians. It also contains large Shastasaurid ichthyosaurs and thalattosaurs, showing somehow similarity with the Carnian Guanling Biota. Preliminary study on the ammonoid materials from Xingyi Fauna has suggested a late Ladinian age instead of early Carnian. The Guanling Biota (Carnian, Late Triassic) contains abundant ichthyosaurs (Guizhouichthyosaurus, Guanlingsaurus, Qianichthyosaurus), thalattosaurs (Anshunsaurus, Xinpusaurus), placodontia sauropterygians (Sinocyamodus, Psephochelys), and the oldest turtle. At least two genera of ichthyosaurs have the body size among the largest in the Mesozoic ichthyosaurs and also show close affinity with the large-bodied ones from North America. The high abundance and diversity of Guanling Biota suggest that it corresponds to the peak stage of the Triassic biodiversity reaching the highest in the Late Triassic following the Middle Triassic radiation, when the global sea level reached its top on the Stage Scale although on the Period Scale in the course of regression. The most characteristic feature of this stage is the pelagic ichthyopterygians, e.g. Guizhouichthyosaurus and Guanlingsaurus, close to the North American forms such as Shastasaurus and Shonisaurus. Therefore, the Guanling Biota represents the full recovery of marine ecosystems after the end-Permian Mass Extinction. 


\title{
Aneurophytalean progymnosperms from the Middle Devonian of North Xinjiang, China [oral presentation]
}

\author{
Jiang Qing ${ }^{1}$, Xu Honghe ${ }^{1,2}$, Wang $\mathrm{Yi}^{1,2} \&$ Feng Jing ${ }^{1,3}$ \\ ${ }^{1}$ Chinese Academy of Sciences, Nanjing Institute of Geology and Palaeontology, Nanjing, P. R. of China; \\ E-mail:qjiang@nigpas.ac.cn \\ ${ }^{2}$ Chinese Academy of Sciences, Nanjing Institute of Geology and Palaeontology, State Key Laboratory of Palaeobiology \\ and Stratigraphy, Nanjing, P. R. of China \\ ${ }^{3}$ University of Chinese Academy of Sciences, Beijing, P. R. of China
}

The progymnosperm is an important group emerging from the Mid Devonian and prevailing in the Late Devonian world. One clade of this group, the Aneurophytales, is found from the Middle to Upper Devonian of Eurasia and the northern part of Gondwana.

Previously Callixylon was reported from the Upper Devonian of Xinjiang. But Mid Devonian progymnosperms were poorly studied. Recently, a plenty of wellpreserved specimens, including compressions and impressions, were collected from the Middle Devonian Hujiersite Formaiton of North Xinjiang, from which two aneurophytalean genera, Aneurophyton and Tetraxylopteris, were recognized and a $\mathrm{PhD}$ thesis is fulfilled with the detailed study of these materials. Here we report two new species in the two genera:

Aneurophyton doui sp. nov. has the relatively simple configuration and small reproductive organs. Its reproductive organ is composed of pinnately arranged recurved organ axes, instead of the dichotomous pattern in Eurasian species A. germanicum (and the variation A. germanicum var. pubescens). Thus, this recurved organ axis with alternately/oppositely attached sporangia at the adaxial side is seen as the basic unit of the generic value. In light of this, the generic diagnosis of Aneurophyton is emended.

Tetraxylopteris ximjiangensis sp. nov. has decussate arrangement of the axes and vegetative appendages, and large reproductive organs. The vegetative appendages are dichotomous one to five times. The reproductive organs dichotomize twice then pinnately branch once with the ultimate axes further dichotomizing twice to three times and terminated by single sporangia.

By comparing the reproductive organs of three genera of Aneurophytales Aneurophyton, Rellimia, and Tetraxylopteris - and analyzing the spatial/temporal distribution of the aneurophytaleans, we may pin the group's origin in northwest Gondwana in the Mid Devonian. In this period, as a series of relatively isolated volcanic arcs, the North Xinjiang, served as a land-bridge between Siberia and northeast Gondwana, and prompted the distribution of the Aneurophytales. 


\title{
A toothed turtle from the Late Jurassic of Xinjiang Autonomous Province, China, and its phylogenetic implications [oral presentation]
}

\author{
Walter G. Joyce ${ }^{1,2}$, Márton $\mathbf{R a b i}^{1}, \mathbf{L i} \mathrm{Lu}^{3}, \mathbf{X u} \mathrm{Xing}^{3}$ \& James M. Clark \\ ${ }^{1}$ Eberbard-Karls University of Tübingen, Department of Geosciences, Tübingen, Germany; \\ E-mail:walter.joyce@uni-tuebingen.de \\ ${ }^{2}$ University of Fribourg, Department of Geosciences, Fribourg, Switzerland \\ ${ }^{3}$ Chinese Academy of Sciences, Institute of Vertebrate Paleontology and Paleoanthropology, Beijing, P. R. of China \\ ${ }^{4}$ Washington University, Department of Biological Sciences, Washington, D.C., U.S.A.
}

The fossil record reveals that turtles repeatedly adapted to a range of marine, freshwater, and terrestrial niches, and that most of these niches are still filled by turtles today. A notable exception is the niche of large-bodied, flat-shelled, bigheaded turtles. Isolated remains of taxa filling this niche are globally known from the Cretaceous and Cenozoic, but their phylogenetic relationships remain controversial. It is therefore unclear if these turtles originated from a common ancestor or if they represent disparate lineages that converged upon the same ecological niche. A particularly puzzling example is Mongolochelys efremovi from the Maastrichtian of Mongolia, because it is particularly isolated morphologically and geographically from all other such turtles.

Here we present the first known cranial material of the Late Jurassic turtle Sichuanchelys from the Junggar Basin, China. The skull is notable because it retains a series of palatal teeth. A phylogenetic analysis firmly places Sichuanchelys sp. as sister to $M$. efremovi and reveals that the $M$. efremovi lineage invaded the large-bodied, flatshelled, big-headed niche independently.

\section{Taxonomy of the Paleocene larger benthic foraminifera in south Tibet (China) [posterpresentation]}

\author{
Michaela Kahsnitz ${ }^{1}$, Zhang Qinghai ${ }^{1} \&$ Helmut Willems ${ }^{1}$ \\ ${ }^{1}$ University of Bremen, Department of Geosciences (FB5), Bremen, Germany; \\ E-mail:michaela.kahsnit?@uni-bremen.de
}

Larger benthic foraminifera (LBF) refer to a group of foraminifera with large test sizes and complicated internal structures. The determination of LBF to the species level is necessary to study palaeoenvironmental changes and to construct biostratigraphy. But taxonomic differentiation of LBF is difficult because it requires axial and/or equatorial cuttings from mm-sized LBF. In south Tibet, the Paleocene LBF have been reported from Tingri, Gamba and Guru areas with the dominant genera of Miscellanea, Daviesina, Lockbartia, Kathina, Ranikothalia and Operculina. However, the taxonomic studies on these LBF are still very poor.

This time we plan to study the taxonomy of the Paleocene LBF by using thin sections from limestone samples and orientated cuttings of LBF from washed 
marly samples. Our work may improve the biostratigraphic studies in south Tibet. Additionally, a regional correlation of biostratigraphy between Tibet and Ladakh will be tentatively carried out, and a general comparison of the LBF in the eastern Tethys (Tibet and Ladakh) and in the western Tethys (Spain and Egypt) will be conducted to study their biogeography.

\section{Foulden Maar and South Island amber (New Zealand) - two exceptional windows into Southern Hemisphere Cenozoic terrestrial ecosystems [invited oral presentation]}

Uwe Kaulfuss $^{1}$, Daphne E. Lee ${ }^{1}$, Jennifer M. Bannister ${ }^{2}$, Jon K. Lindqvist ${ }^{1}$, John G. Conran ${ }^{3}$, Dallas C. Mildenhall ${ }^{4}$, Elizabeth M. Kennedy, Vincent Perrichot $^{5}$, Mark Maraun ${ }^{6}$ \& Alexander R. Schmidt ${ }^{7}$

${ }^{1}$ University of Otago, Department of Geology,Dunedin, New Zealand; E-mail: uwe.kaulfuss@otago.ac.nz

${ }^{2}$ University of Otago, Department of Botany, Dunedin, New Zealand

${ }^{3}$ The University of Adelaide, School of Earth and Environmental Sciences, Adelaide, South Australia, Australia

${ }^{4}$ GNS Science, Lower Hutt, New Zealand

${ }^{5}$ Université Rennes, Géosciences \& Observatoire des Sciences de l'Univers de Rennes, Rennes, France

${ }^{6}$ Georg-August University, Blumenbach Institute of Zoology and Anthropology, Göttingen, Germany

${ }^{7}$ Georg-August University, Courant Research Centre Geobiology, Göttingen, Germany

Foulden Maar, Otago, New Zealand, is an Early Miocene maar-diatreme volcano with a crater filled by highly fossiliferous lacustrine diatomite. Since investigations began in late 2003, several thousand exquisitely preserved macro- and microfossils have been collected from plants and animals that lived in or around the maar-lake. The flora includes ferns, leaves with cuticle, flowers with pollen, fruits, seeds and wood, which, together with pollen data, are indicative of a diverse subtropical Lauraceae-dominated rainforest growing on volcanic soils around the lake. Diverse, mainly ground-dwelling insects and spiders from eight orders and arthropod-plant interactions show that arthropods were a key component of the forest ecosystem. Aquatic taxa include fish, diatoms, sponges, Chrysophyceae, a few water plants and insects. The majority of arthropods from Foulden Maar have close representatives in the modern fauna, but many of the plant taxa are now extinct in New Zealand. Together, these fossils provide an unrivalled opportunity to reconstruct a well-dated Southern Hemisphere, mid-latitude, earliest Miocene lacustrine/forest ecosystem.

Recently, amber from the South Island, New Zealand has become an exceptional novel paleontological source for terrestrial microorganisms and arthropods with an otherwise poor fossil record. Amber is nearly ubiquitous in coal/lignite and non-carbonaceous sediments throughout the South Island but no animal inclusions and only a few floral remains have been recognised until now. In an ongoing study, we have collected amber from the Upper Cretaceous, Eocene, 
Oligocene, Miocene and Pliocene, including discrete blocks, rounded "amberpebbles", millimetre-sized drops, sometimes associated with wood, and tiny resin plugs on leaf fossils. The preliminary study of these samples has revealed a range of well-preserved inclusions, including (1), araucariacean wood, (2), fungi, (3), sheathed prokaryotic filaments, (4), arachnids such as mites, a possible tick and spiders, (5), springtails (Collembola), and (6), insects including beetles, dipterans, hymenopterans, hemipterans, and lepidopterans. These finds attest to the quality of New Zealand amber inclusions and their remarkable potential for reconstructing past terrestrial ecosystems.

\section{Understanding the paleoenvironment of the Mid-Miocene Randeck Maar lake: recap and new data [oral presentation]}

Andrea K. Kern ${ }^{1}$, Michael W. Rasser ${ }^{1}$, Katarzyna Stachura-Suchoples ${ }^{2}$, Johanna Kovar-Eder $^{1}$, James H. Nebelsick ${ }^{3}$, Anita Roth-Nebelsick ${ }^{1}$, Günther Bechly ${ }^{1}$, Günther Schweigert ${ }^{1}$ \& Reinhard Ziegler $^{1}$

1Stuttgart State Museum of Natural History, Stuttgart, Germany; E-mail: andrea.kern@smns-bw.de

${ }^{2}$ Free University, Botanic Garden and Botanical Museum, Berlin, Germany

${ }^{3}$ Eberbard-Karls University of Tübingen, Department of Geosciences, Tübingen, Germany

The Southern German Randeck Maar is a known fossil lagerstätte (late Early/early Middle Miocene) showing a great number and variety of fossils, especially in insects and plants. Based on reevaluations of collection material as well as new excavations, a reconstruction of different environments in and around the lake could be done; however, some indications remained inconclusive or even contradictive.

New investigations focus on a short detail-studied sequence to understand the lake evolution. The use of biotic and abiotic proxies shall combine new data to clarify water chemistry, the stability of the lake and solve the origin of the finely laminated deposits.

Furthermore, a paleoclimatic estimate based on plant-fossils can be provided. The Integrated Plant Record (IPR) vegetation analysis and fruit ecology suggest a subhumid sclerophyllous forests as the most likely vegetation type, which characteristically develops under seasonally dry climate only. Also the Coexistence Approach indicates a very warm climate with a clear seasonality in rainfall. This raises the question about the intensity of seasonal patterns during the Miocene Climatic Optimum. 


\title{
Fossil filamentous microfungi as amber inclusions [oral presentation]
}

Elina Kettunen ${ }^{1} \&$ Jouko Rikkinen ${ }^{1}$

${ }^{1}$ University of Helsinki, Department of Biosciences, Helsinki, Finland; E-mails: elina.kettunen@helsinki.fi d
jouko.rikkinen@helsinki.fi

Fungi comprise one of the most diverse groups of organisms on Earth, and much of this diversity consists of different groups of microfungi. Most of the microfungi known as "moulds" belong to hyphomycetes, which are asexual stages of various filamentous fungi that largely belong to Ascomycota. Extant hyphomycetes or moulds form an extremely species-rich, ecologically diverse and economically important group. Many of them are decomposers of organic matter, but also parasites and pathogens of plants and animals are common. Even though fungal fossils are relatively rare compared to the fossils of plants and animals, several wellpreserved fossils of moulds are preserved as amber inclusions. Data about the diversity and ecology of these fossils can also be combined with molecular data collected from the extant species, and together they can shed light on the evolution and biogeography of extant fungal groups.

\section{Diversity of mites from New Zealand amber [poster presentation]}

Anna Philie Kiecksee ${ }^{1}$, Uwe Kaulfuss ${ }^{2}$, Daphne E. Lee ${ }^{2}$, Eva-Maria Sadowski ${ }^{1}$, Alexander R. Schmidt ${ }^{1} \&$ Mark Maraun ${ }^{3}$

\author{
${ }^{1}$ Georg-August University, Courant Research Centre Geobiology, Göttingen, Germany; \\ E-mails: kiecksee_philie@gmx.de; eva-maria.sadowski@geo.uni-goettingen.de \& alexander.schmidt@geo.uni- \\ goettingen.de \\ ${ }^{2}$ University of Otago, Department of Geology, Dunedin, New Zealand; \\ E-mails: uwe.kaulfuss@otago.ac.nz。daphne.lee@otago.ac.nz. \\ ${ }^{3}$ Georg-August University, Blumenbach Institute of Zoology and Anthropology, Göttingen, Germany; \\ E-mail:mmaraun@gwdg.de
}

Although amber is ubiquitous in Cenozoic lignites from Otago and Southland, no bioinclusions have been reported from New Zealand, so far. Here, we present the discovery of diverse mites from New Zealand amber. Since the fossil resin is opaque and fragile, we have established a protocol for the preparation of its inclusions. By embedding in epoxy resin and applying vacuum, the optical quality of the amber and its stability were improved. By this means, 11 Acari representatives were discovered, revealing a significant taxonomic and ecological diversity. The fossils represent adults as well as juvenile stages of mesostigmatid, prostigmatid, oribatid and astigmatid mites. The presence of a leaf litter horizon is indicated by a phthiracarid mite, the endophagous larvae of which occur in coniferous as well as in deciduous litter. Since modern Phthiracaridae and Astigmata are not widespread in the modern tropics, the early Miocene climate in southern New Zealand might have been warm temperate to subtropical rather than tropical. The 
fossils reveal a diverse soil-dwelling mite community typical of modern warm temperate to subtropical forest floors.

\title{
On the origin of the kelp forests [oral presentation]
}

Steffen Kiel ${ }^{1}$, Michael Krings ${ }^{2}$, Cindy Looy $^{3}$, Rosemary Romero $^{3}$ \& James L. Goedert $^{4}$

${ }^{1}$ Georg-August-Universität, Geowissenschaftliches Zentrum, Abteilung Geobiologie, Göttingen, Germany;

E-mail:skiel@gwdg.de

${ }^{2}$ Bayerische Staatssammlung für Paläontologie und Geologie, München, Germany

${ }^{3}$ University of California, Department of Integrative Biology, Berkeley, California, U.S.A.

${ }^{4}$ Burke Museum of Natural History and Culture, Seattle, Washington, U.S.A.

Kelps include the largest benthic organisms in the world and are currently assumed to have radiated in the North Pacific following the onset of the late Cenozoic cooling. The oldest fossils of this group so far are 13 to 17 million-year-old Miocene fossils from California, which have a branching morphology similar to kelp genera Nereocystis and Pelagophycus, close relatives of the Giant Kelp (Macrocystis pyrifera). Recently discovered macroalgal holdfasts in early Oligocene carbonate concretions from Washington State have the potential to show that kelps evolved and diversified significantly earlier than indicated by our current understanding of the fossil record. The preserved haptera (branching finger-like structures) of the holdfasts strongly resemble those within the Macrocystis-clade. Split surfaces, thin sections, and synchrotron-based X-ray Micro-Tomography show the 3D morphology, differrent tissue types and internal structure of the holdfasts. The co-occurring fossils as well as oxygen isotope investigations of associated well-preserved shell material are used to reconstruct the paleoenvironment of these earliest kelps.

\section{Life histories and growth patterns of Triassic Sauropterygia [oral presentation]}

\author{
Nicole Klein ${ }^{1} \&$ Eva-Maria Griebler ${ }^{2}$ \\ 1 Stuttgart State Museum of Natural History, Stuttgart, Germany; \\ E-mail:nicole.klein@smns-bw.de \\ 2Johannes-Gutenberg University, Institute of Zoology, Mainz, Germany
}

Long bone histological studies had revealed that the four major groups of Triassic Sauropterygia are well to distinguish on the basis of their histological features. Besides a variety of primary bone tissues and patterns of vascular canal organization, fast deposited bone tissues, a moderate to high vascular density, and a radial vascular canal organization seems to dominate in the Lower Muschelkalk pachypleurosaurs and nothosaurs. This implies clearly increased growth rates - when 
compared to modern reptiles. Interestingly, tissue organization increases and vascular density decreases in stratigraphically younger forms of pachypleurosaurs and nothosaurs, whereas this trend is vice versa in Pistosauroidea and placodonts. Further on, all those taxa show differences in their developed growth marks. Whereas in placodonts and the pachypleurosaur $A$. beterodontus mainly diffuse irregular annuli or an arrangement of vascular canals in rows is the only yet identified cyclicality, the pachypleurosaurs from the Alpine Triassic, nothosaurs, and early Pistosauroidea are well suited for skelettochronological studies and show annual growth marks.

\section{Quantitative ecological analysis on small insectivorous mammals [oral presentation]}

Johannes Klietmann ${ }^{1}$, Lars W. van den Hoek Ostende ${ }^{2}$, Doris Nagel $^{1}$ \& Michael Rummel ${ }^{3}$

${ }^{1}$ University of Vienna, Department of Palaeontology, Vienna, Austria;

E-mails: johannes.klietmann@yahoo.de \& doris.nage@univie.ac.at

${ }^{2}$ Naturalis, Leiden, The Netherlands; E-mail: Lars.vandenhoekostende@naturalis.nl

${ }^{3}$ Naturmuseum, Augsburg, Germany; E-mail: Michael.rummel@angsburg.de

Ecological analyses of small insectivorous mammals were either not done or only by listing taxa, rare, common or absent in different localities. For this study, occurrence data for Eulipotyphla and the last European marsupial, Amphiperatherium, were gathered from European and Anatolian Early Miocene localities to be used in quantitative analyses. The principal components analysis revealed differences in taxa composition and frequency between the various sites. Comparison to previous ecological analyses allows grouping the taxa into two ecological sets: The larger set, consisting of Dimylidae, Soricidae, Heterosoricidae, Talpidae, Plesiosoricidae and Amphiperatherium, is humidity dependent. These animals are common in humid and rare or absent in dryer localities. The second set, consisting of the Erinaceidae, the shrews Oligosorex and Lartetium and the moles Desmanodon and Theratiskos, is aridity tolerant. These animals are dominant in dryer sites, but also found in humid localities. The quantitative analysis corroborates the assumed preferences of the taxa, and demonstrates that quantitative analyses on these animals yield valuable results.

\section{High resolution micro-computed tomography (micro-CT) and 3D reconstruction of modern planktonic foraminifera [oral presentation]}

Janine Könen ${ }^{1} \&$ Martin R. Langer ${ }^{1}$

${ }^{1}$ Rheinische Friedrich-Wilhelms University, Steinmann Institute of Geology, Mineralogy and Palaeontology, Bonn, Germany; E-mail:janine.koenen@uni-bonn.de 
Growth patterns in planktonic foraminifera, shell thickness and increase in volume reflect conditions and processes of specific oceanic environments. We have applied high-resolution X-ray micro-computed tomography (micro-CT) to a variety of modern planktonic foraminifera collected off Ascension Island (S-Atlantic Ocean). Micro-CT allows 3D reconstructions by stacking groups of $2 \mathrm{D}$ slice images of microscopic organisms. Volume rendering, biometric measurements and detailed external and internal morphological features can be visualized and quantified with this technique.

All foraminifera analyzed exhibit exponential growth patterns where volume increase is most pronounced within the last 4 to 8 chambers. Patterns of volume increase differ significantly between symbiont-bearing spinose taxa and nonspinose counterparts. The final chamber in spinose species constitutes distinctly larger portions of the total shell volume than in non-spinose planktonics. Shells of deep- and shallow-water taxa differ in their ratio of shell volume to internal chamber lumina and can be used as proxies for environmental reconstructions.

\section{Articulated lungfish from the Triassic fossil lagerstätte Madygen (Kyrgyzstan, Central Asia) [poster presentation]}

Ilja Kogan ${ }^{1}$, Piotr Skrzycki², Sebastian Voigt ${ }^{3} \&$ Jan Fischer $^{3}$

${ }^{1}$ Technical University Bergakademie Freiberg, Institute of Geology, Freiberg/Sa., Germany; E-mail: i.kogan@gmx.de ${ }^{2}$ Polish Academy of Sciences, Institute of Paleobiology, W arsaw, Poland

${ }^{3}$ Geoskop Urweltmuseum/Burg Lichtenberg (Pfaly), Thallichtenberg, Germany

Post-Palaeozoic dipnoans are mainly known by isolated tooth plates and single cranial bones, fully articulated finds being very rare in the fossil record. These few exceptions consist of two Early and two Middle Triassic forms from Gondwanian areas. The Middle Triassic Madygen Formation of Kyrgyzstan (Central Asia) is the only Northern Hemisphere locality yielding complete lungfish skeletons, described as Asiatoceratodus sharovi by Vorobyeva in 1967 . New material referable to this taxon was found during four field campaigns conducted by the Freiberg working group from 2006 to 2009.

All dipnoan remains come from the so-called Sharov quarry, a highly productive outcrop of prodeltaic lacustrine facies. A complete specimen shows an unusual pattern of denticles on the caudal fin rays. 4-5 cusps are present on the ridges of the tooth plates indicating an early ontogenetic stage. Since Asiatoceratodus is regarded as a supposed close relative of the recent Neoceratodus, a detailed study of the new material may result in resolving their relationship and the actual position of Asiatoceratodus within the dipnoan phylogeny. 


\title{
Palaeoenvironmental studies on the Late Saalian/Eemian lake system of Jänschwalde (Northern Germany, Brandenburg, Lower Lusatia) [oral presentation]
}

Annette Kossler ${ }^{1}$, Ingo Raufuß ${ }^{1}$, Marcus Schneider ${ }^{2}$, Horst Rösler $^{2}$ \& Eberhard Bönisch ${ }^{2}$

${ }^{1}$ Free University Berlin, Institute of Geological Sciences, Berlin, Germany;

E-mail:kossler@zedat.fu-berlin.de

${ }^{2}$ Brandenburgisches Landesamt für Denkmalpflege und Archäologisches Landesmuseum (BLDAM), Außenstelle

Braunkoblenarchäologie, Calau, Germany; E-mail:info.bk@bldam-brandenburg.de

In the opencast mine Jänschwalde ( $\sim 15 \mathrm{~km} \mathrm{NE}$ of Cottbus, Brandenburg), a north-south orientated basin structure of approx. $1700 \mathrm{~m}$ length and $400 \mathrm{~m}$ breadth filled with limnic sediments of the Saalian Late Glacial and the Eemian Interglacial was detected within the surface layer formation. Our previous studies, which are performed by an interdisciplinary team of palaeontologists, archaeologist and geologists (Vattenfall Europe Mining AG), have shown that it is a unique continental archive, where especially the transition Saalian/Eemian is well exposed. The sediments of the former lake have provide several remains of vertebrates, invertebrates and botanical macro remains, which allow for age determination and precise palaeoenvironmental and palaeoclimatic analyses. With the aid of the sediment data and the analyses of the fossil remains, we are able to reconstruct the development of the lake and its vicinity during the time span between approx. 130,000-125,000 years BP.

\section{A foraminiferan microfauna from the Late Cretaceous of Thuringia: preliminary results [posterpresentation]}

\author{
Christian Kreher ${ }^{1}$, Olaf Elicki ${ }^{1}$ \& Michael Magnus ${ }^{1}$ \\ ${ }^{1}$ Technical University Bergakademie Freiberg, Institute of Geology, Freiberg/Sa., Germany; \\ E-mail:cbristian.kreher@student.tu-freiberg.de
}

A substancial foraminiferan microfauna is presented from local deposits of boreal Late Cretaceous rocks of the Ohmgebirge Mountains (Thuringia). 17 localities provided 3 lithologies, from which one (so-called "Pläner") was chosen for succeeding micropalaeontological investigation. From this limestone, more than 7000 foraminifers as well as ostracods, sponge spicules, echinoderms, numerous calcispheres, non-determined shells, and rare vertebrate remains were obtained. The Foraminifera are represented by 27 morphologies, 5 of which are interpreted as planktonic and 22 as benthic. The quantitative ratio of planktonic to benthic Foraminifera allows the definition of 3 biofacies-types, illustrating an increase of pelagic conditions: bt-I (p:b = 40:60), bt-II (p:b = 50:50), bt-III ( $\mathrm{p}: \mathrm{b}=60: 40)$. Together with the micritic Coccolith-dominated lithology, a distal and oxic deposi- 
tional area below storm wave-base is concluded. The occurrence of the planktonic index foraminifer Rotalipora cushmani, first reported here, significantly extends the biostratigraphic range of the Cretaceous succession of the Ohmgebirge Mountains up to the late Cenomanian.

\title{
Phylogenetic implications of tooth replacement patterns in stem- group teleosts (Neopterygii) [oral presentation]
}

\author{
Jürgen Kriwet ${ }^{1} \&$ Cathrin Schwarz
}

\section{${ }^{1}$ University of Vienna, Department of Palaeontology, Vienna, Austria; E-mails: juergen.kriwet@univie.ac.at \& cathrin.schwar:@univie.ac.at}

Crown-group teleosts form the most diverse group of living vertebrates and are characterized by continuous, life-long replacement of teeth. Functional teeth develop either in the soft tissue outside of tooth bearing bones ("extraosseous") or inside bony pockets ("intraosseous") similar to the condition in crocodiles and mammals. Generally accepted is the evolutionary scenario of extraosseous tooth development, which is present in the majority of crown-group teleosts and represents the plesiomorphic condition in teleosts. The intraosseous replacement mode seemingly evolved independently in at least three teleostean clades and represents the derived state. Important questions nevertheless remain: relation of developing replacement tooth to underlying structure to which it finally attaches; what are the processes for relocating replacement teeth underneath functional teeth and encasing them into bone; how does this affect the relation of dermal and endochondral bones. Here, we present new information about tooth replacement patterns in basal stem-group teleosts (e.g. Pycnodontiformes, Pachycormiformes) to address these questions.

\section{How did the end-Permian extinction event affect the flora [keynote presentation]}

\section{Evelyn Kustatscher ${ }^{1,2}$}

\author{
${ }^{1}$ Naturmuseum Südtirol, Bolzano/Bozen, Italy; E-mail: Evelyn.Kustatscher@naturmuseum.it \\ 2Ludwig-Maximilians-Universität München, Department für Geo- und Umweltwissenschaften, Paläontologie und \\ Geobiologie, and Bayerische Staatssammlung für Paläontologie und Geologie, München, Germany
}

The Permian-Triassic boundary marks the largest mass extinction in Earth history, primarily in the marine realm. The terrestrial plant record from this period of time is scarce and mainly restricted to palynological evidence. Moreover, several groups of plants historically regarded as typically Mesozoic (e.g., cycads, corystosperms) are now known from the uppermost Pennsylvanian and Permian, appearing first in drier or temporarily dry (sub)tropical areas. The disappearance of most arborescent 
lycopsids, cordaites, and certain pteridosperm groups during the Late Pennsylvanian to Permian is one of the most important floral changes of the Palaeozoic, but did not occur at the same time worldwide. As a result, it remains difficult to evaluate how much of the loss in diversity occurred actually at the PermianTriassic boundary and was a direct result of the extinction event. Also, the time constrain and dynamics of the biotic recovery of the flora after the end-Permian mass extinction continue to be debated. It was widely believed in the past that the earliest Triassic floras from central Europe, China, Australia and Siberia were dominated by herbaceous lycophytes (especially Pleuromeia), corroborated in part by the fact that the palynological record from the earliest Triassic lacks evidence of gymnosperms. As to whether these and other plant groups are in fact missing during this period of time or were just restricted to small refugial areas remains a matter of debate. However, recent discoveries from China, together with new palynological studies at high latitudes, suggest that Early Triassic floras were quite diverse and included lycophytes, sphenophytes, ferns, seed ferns (Peltaspermales), and conifers. The fact that the Anisian flora is much more diversified than during the Late Permian suggests that the end-Permian mass extinction did not affect the terrestrial flora as much as the marine and terrestrial fauna.

\title{
The ferns of the late Ladinian (Middle Triassic) flora from Monte Agnello (Dolomites, N-Italy) [posterpresentation]
}

Evelyn Kustatscher ${ }^{1,2}$, Elio Dellantonio ${ }^{3}$ \& Johanna H. A. Van Konijnenburgvan Cittert $^{4,5}$

\author{
${ }^{1}$ Naturmuseum Südtirol, Bolzano/Bozen, Italy; E-mail: Evelyn.Kustatscher@naturmuseum.it \\ ${ }^{2}$ Ludwig-Maximilians-Universität München, Department für Geo- und Umweltwissenschaften, Paläontologie und \\ Geobiologie, and Bayerische Staatssammlung für Paläontologie und Geologie, München, Germany \\ ${ }^{3}$ Museo Geologico delle Dolomiti, Predazzo, Italy; E-mail: elio.dellantonio@mtsn.it \\ ${ }^{4}$ Laboratory of Palaeobotany and Palynology, Utrecht, The Netherlands; E-mail: J.H.A.vanKonijnenburg@uu.nl \\ ${ }^{5}$ National Centre for Biodiversity Naturalis', Leiden, The Netherlands
}

Several fern remains are described from the para-autochthonous late Ladinian flora of the Monte Agnello (Dolomites, N-Italy). The plants are preserved in subaerially deposited pyroclastic layers. Some ferns are typical elements of the Middle Triassic of the Dolomites (Neuropteridium elegans), but several taxa are described for the first time (Phlebopteris fiemmensis, Cladophlebis ladinica, Chiropteris monteagnellii). The matoniaceous fern Phlebopteris fiemmensis is now the oldest known species in the genus Phlebopteris. The fern family Dipteridaceae (Thaumatopteris sp.) has not been recorded previously from European sediments as old as the Ladinian. Although stratigraphically attributed to the late Ladinian, the flora shows a higher diversity in ferns than coeval floras from this area, although characteristic elements of the Middle Triassic of the Dolomites (e.g., Anomopteris, Danaeopsis, Gordonopteris, Sphenopteris schoenleiniana) are missing. 


\title{
Testing structured-light 3D scanning and photogrammetry for palaeontological purposes [poster presentation]
}

Michael Laaß ${ }^{1,2}$, Ramona Dries ${ }^{3}$, André Gensch ${ }^{3}$, Corinna Hoff ${ }^{4}$, Eberhard Frey ${ }^{1}$ \& Anders Kaestner ${ }^{5}$

1 State Museum of Natural History, Department of Geosciences, Karlsrube, Germany;

E-mails:michael.laass@gmx.de \&odino.frey@smnk.de

${ }^{2} \mathrm{R} u$ precht-Karls University, Institute of Earth Sciences, Heidelberg, Germany

${ }^{3}$ Karlsrube Institute of Technology (KIT), Karlsrube, Germany; E-mails: RamonaDries@gmx.de \&

gensch.an@arcor.de

${ }^{4}$ GONOMETRICS, Halle/Sa., Germany; E-mail: hoff@gonometrics.de

${ }^{5}$ Neutron Imaging and Activation Group, Paul Scherrer Institute, Villigen PSI, Switzerland;

E-mail: anders.kaestner@psi.ch

In palaeontology 3D laser scanning, structured-light 3D scanning (SLS) and photogrammetry have become increasingly popular, and numerous postprocessing software applications exist, the underlying algorithms and accuracy of which are often poorly documented.

We tested the accuracy of the SLS system DAVID 3.8 Pro and the photogrammetric software Agisoft Photoscan Professional v. 0.9.0 by measuring a skull of Lystrosaurus (Therapsida, Anomodontia) with both methods and comparing them with a high-resolution 3D model of the same skull generated from neutron tomographic data measured at the Paul Scherrer Institute, Switzerland.

The mean difference between the DAVID model and the reference model is $0.8 \mathrm{~mm}(\sigma=0.69 \mathrm{~mm})$, whereas the mean difference between the Photoscan model and the reference model is $0.37 \mathrm{~mm}(\sigma=0.53 \mathrm{~mm})$. In some cases, both models differ by up to $9 \mathrm{~mm}$ from the reference model due to systematic shadowing effects. We suggest that 3D photogrammetry and DAVID structured-light 3D scanning are only adequate for the generation of $3 \mathrm{D}$ models of fossils with simple geometry. For such objects, the differences between object and 3D model are usually less than $1 \mathrm{~mm}$.

\section{The inner ear of Kawingasaurus (Synapsida, Anomodontia) - an adaptation to ground vibration detection? [oral presentation]}

\author{
Michael Laaß ${ }^{1,2}$, Eberhard Frey ${ }^{1} \&$ Anders Kaestner ${ }^{3}$ \\ 1 State Museum of Natural History, Department of Geosciences, Karlsrube, Germany; \\ E-mail:michael.laass@gmx.de@dino.frey@smnk.de \\ ${ }^{2} \mathrm{R} u p r e c h t-K a r l s$ University, Institute of Earth Sciences, Heidelberg, Germany \\ ${ }^{3}$ Neutron Imaging and Activation Group, Paul Scherrer Institute, Villigen PSI, Switzerland; \\ E-mail:anders.kaestner@psi.ch
}


Kawingasaurus from the Upper Permian Kawinga Formation in Tanzania is a small anomodont, which was separated from the genus Cistecephalus by Cox in 1972. Due to its unusual postcranial anatomy, Cox came to the conclusion that Kawingasaurus probably was adapted to a digging mode of life.

An investigation of the internal cranial anatomy of Kawingasaurus with the help of neutron tomography at the Paul Scherrer Institut, Switzerland, revealed enlarged inner ears with extraordinary inflated vestibules. The vestibule has a volume of $182 \mathrm{~mm}^{3}$, which is about 25 times larger than the human one, although Kawingasaurus has only a basal skull length of ca. $40 \mathrm{~mm}$.

Vestibular inflation is known from taeniolabidid multituberculates, some frogs, caecilian amphibians, amphisbaenids and the burrowing turtle Gopherus polyphemus (Luo \& Ketten 1991), i.e. taxa with a fossorial lifestyle or animals using seismicrange low frequencies for communication. This suggests that the inner ears of Kawingasaurus may have functioned as ground vibration detectors and at the same time supports the hypothesis of a fossorial lifestyle of Kawingasaurus.

\title{
The first evidence of insect endophytic oviposition from the Wettin Member of the Siebigerode Formation of the Saale Basin (Upper Carboniferous, Stefanian C, Gzhelian) [posterpresentation]
}

\author{
Michael Laaß ${ }^{1,2}$ \& Corinna Hoff ${ }^{3}$ \\ 1 State Museum of Natural History, Department of Geosciences, Karlsrube, Germany; \\ E-mail:michael.laass@gmx.de \\ ${ }^{2} \mathrm{R} u$ precht-Karls University, Institute of Earth Sciences, Heidelberg, Germany \\ ${ }^{3}$ GONOMETRICS, Halle/Sa., Germany; E-mail: hoff@gonometrics.de
}

The reproductive strategy of laying eggs into plant tissue (endophytic oviposition) is especially known from modern Odonatoptera (Zygoptera). The advantage of this strategy is the protection of the eggs against predation, variations of wetness and flooding (Béthoux et al. 2004).

In the fossil record, endophytic oviposition has previously been reported predominantly from the Cenozoic, but also from the Mesozoic, the Permian and in two cases from the Upper Carboniferous (Moisan et al. 2012). The latter are scars in the outer cortex of sphenophyte stems.

We describe here a similar tracefossil from the Wettin Member of the Siebigerode Formation of the Saale Basin (Upper Carboniferous, Gzhelian, Stefanian C), probably on a leaf of Cordaites. The endophytic cavities are arranged in rows as is known from extant Zygoptera. They are significantly smaller than the cavities described by Béthoux et al. (2004).

This further evidence of endophytic oviposition from the Upper Carboniferous shows that the reproductive strategy in question was obviously more widespread in Palaeozoic insects than previously thought, and at least two different tracemakers must have existed. 


\title{
Late Carboniferous conodonts from southeastern Liaoning [oral presentation]
}

\author{
Lang Jiabin ${ }^{1,2}$, Wang Chengyuan ${ }^{1,2,3} \&$ Chen Feng $^{1,2}$ \\ ${ }^{1}$ Ministry of Education, Key Laboratory for the Evolution of Past Life and Environment in Northeast Asia, \\ Changchun, P. R. of China; E-mail: langjb@jlu.edu.cn \\ 2Jilin University, Research Center of Paleontology and Stratigraphy, Changchun, P. R. of China \\ ${ }^{3}$ Chinese Academy of Sciences, Nanjing Institute of Geology and Palaeontology, Nanjing, P. R. of China
}

The Carboniferous strata are widely distributed in North China, especially well developed in south-eastern Liaoning, including the Niumaoling section in Benxi, which is represented in Taizihe Village, and the Jinzhou-Fuzhouwan area. The Benxi Formation and Taiyuan Formation are very characteristic, with continentalmarine alternating facies.

The Carboniferous conodonts, Idiognathodus podolskensis, Neognathodus inaequalis, etc. found in the upper part of Benxi Formation, approximately correspond to the middle-upper Moscovian of the middle Late Carboniferous. Whereas the strata and conodont fossils at Benxi Formation in southern Liaoning not only include the middle-upper Moscovian deposition, the same part of the Benxi Formation in eastern Liaoning, but also include the upper Bashkirian to early Moscovian deposition (Idiognathoides corrugatus, Declinognathodus margindosus etc.). Although the marine strata of the Taiyuan Formation in the Jinzhou-Fuzhouwan area is very thin but quite rich in conodonts, mainly including Streptognathodus species, it approximately corresponds to the Gzhelian of the Late Carboniferous. Therefore, it will be more comprehensive and compared with those employed in China and abroad.

\section{A new look into fossil heads - palaeoneurology in the digital age [oral presentation]}

\section{Stephan Lautenschlager ${ }^{1}$}

${ }^{1}$ University of Bristol, School of Earth Sciences, Bristol, U.K.; E-mail: glzsl@bristol.ac.uk

Palaeoneurology, the study of fossil endocranial anatomy and its evolution, has a long-standing tradition in palaeontology. Due to the poor preservation potential of soft-tissue structures, early researchers had to rely on a few exceptionally preserved fossil endocasts - naturally occurring moulds of the endocranial cavity, which are representative of the gross anatomy of the brain and associated structures - or to prepare artificial endocasts through serial grinding or casting techniques. The advent of non-destructive imaging techniques (i.e., CT scanning, synchrotron tomography) has revolutionised this field and facilitated the acquisition and study of digital endocasts to gain insight into brain anatomy, development and neurosensorial function. 
In three examples, the potential of digital imaging and reconstruction techniques for palaeoneurological studies is demonstrated: (1) Reconstruction of the endocranial anatomy and evaluation of sensory and cognitive capabilities in Therizinosauria, an enigmatic group of herbivorous theropod dinosaurs. Results of this study reveal that therizinosaurs had inherited a well developed neural repertoire from carnivorous ancestors and adapted this sensory system for foraging, predator evasion and social complexity. (2) Appraisal of the ontogenetic trajectories occurring in the ornithischian endocranium, exemplified by different growth stages of the small ornithischian dinosaur Dysalotosaurus lettowvorbecki. The comparison shows that the endocranial anatomy underwent considerable changes during growth, but also that functional elements were already well developed in early stages. (3) A comparison of the endocranial anatomy of Phytosauria and Crocodylia, which demonstrates that the convergent morphology found in the cranial skeleton is also manifested in the endocranium, indicating reduced functional plasticity.

\section{Digital dissection - using contrast-enhanced CT scanning to elucidate hard- and soft-tissue anatomy of a Common Buzzard [posterpresentation]}

\section{Stephan Lautenschlager ${ }^{1}$}

${ }^{1}$ University of Bristol, School of Earth Sciences, Bristol, U.K.; E-mail: glzsl@bristol.ac.uk

Gross dissection is an established method with a long-standing history to gain detailed information about animal physiology. Recent advances in computed tomography (CT) scanning technologies and their wide availability have led to a surge of non-destructive imaging techniques in biology and palaeontology, vastly enhancing the possibility of visualising complex anatomical structures. However, due to the low intrinsic X-ray absorption, CT scanning rarely provides sufficient resolution of unmineralised soft tissues. Contrast-enhanced CT scanning using iodine staining have produced promising results to increase differential attenuation. To demonstrate the full potential of this method, the results of a "digital dissection" of a buzzard (Buteo buteo) are presented here. The digital visualisation of contrast-enhanced soft-tissues offers a unique opportunity to describe and illustrate these structures in detail and in an osteological context. The cranial musculature, ligaments, endocranial and neurovascular structures and keratinous tissues are identified and visualised. Results of this digital dissection provide valuable information for comparative studies on avian anatomy, biomechanical applications and interpretation of soft-tissue structures in fossil taxa. 


\title{
The Early Palaeozoic - a time of dramatic climatic, environmental and evolutionary changes [keynote presentation]
}

\author{
Oliver Lehnert ${ }^{1,2}$ \\ ${ }^{1}$ Friedrich-Alexander University Erlangen-Nümberg, Geo-Center of Northern Bavaria, Section Palaeoenvironmental \\ Research, Erlangen, Germany \\ ${ }^{2}$ Lund University, Department of Geology, Lund, Sweden; E-mail: Oliver.Lebnert@geol.lu.se
}

The Early Palaozoic is a critical interval in the evolution of life. Triggers for major innovations and tremendous radiations have been widely discussed. The 'Cambrian Explosion', 'Cambrian Substrate Revolution', the 'Great Ordovician Biodiversification Event' (GOBE) and 'Devonian Nekton Revolution' are famous targets of intense studies.

The 'Cambrian Explosion' is a result of taphonomic windows reflected by quite a few famous Konservat-Lagerstätten and has its roots in the Neoproterozoic based on molecular-clock data. Recently, it became evident that this 'Cambrian Innovation' involving skeletalisation and a range of new body plans was followed by the Ordovician increase in biodiversity at the family, genus and sprecies levels (GOBE). Both events as well as the Devonian Nekton Revolutions seem to be linked and potentially reflect a large-scale evolution.

Faunal evolution was triggered by long-lasting physico-chemical and biological processes. Palaeoclimate changes presumably represent a major parameter influencing primary production in the World's oceans, the long-term rise and demise of ecosystems, as well as evolutionary events. The early Palaeozoic was described as an environmentally stable long-lasting greenhouse period. New data on biodiversity crises and major changes in the stable isotope record are in contradiction with this view.

Climate development and the waning and waxing of high-latitude continental ice sheets can be deduced from oxygen isotope ratios of conodont apatite. This record shows successive long-term cooler and warmer periods, interrupted by a number of short-term glaciations. Ordovician diversity peaks compare well with colder periods or glacials, phases with low diversity coincide with warmer intervals or 'interglacials'. However, it was suggested that the extinctions during the Hirnantian preferentially hit faunas displaced to the continental margins due to extensive exposure of tropical platforms during the glacial maximum.

In general, it seems that Palaeozoic faunas flourished during colder periods and that e.g. Silurian and Devonian faunas were strongly affected during warmer climates. Stromatoporoid-coral mega-reef complexes flourished during the cool period in the Emsian through Givetian, major reef crises and extinctions are connected to global warming (e.g., Frasnian-Famennian). It is assumed that palaeoclimate changes strongly influenced macro-evolution and played a major role in early Palaeozoic extinction and radiation events. 


\title{
A volumetric approach to reconstructing ammonite life-habits [poster presentation]
}

\author{
Robert Lemanis ${ }^{1}$, René Hoffmann ${ }^{1} \&$ Stefan Zachow $^{2}$ \\ ${ }^{1}$ Rubr University, Institute of Geology, Mineralogy and Geophysics, Bocbum, Germany; \\ E-mails:Robert.Lemanis@rub.de \& Rene.Hoffmann@rub.de \\ ${ }^{2} Z$ use Institute, Department of Scientific Visualization and Data Analysis, Berlin, Germany; \\ E-mail: zachow@zib.de
}

The function of the ammonite phragmocone and subsequent palaeoecological interpretations have been debated for over a century. Juvenile ammonites are largely considered to be planktonic; however, adult ammonites have been reconstructed as nektonic or benthic. Previous attempts to calculate the buoyancy of ammonites have utilized mathematical models that have necessarily simplified aspects of shell geometry. We employed high-resolution computed tomography to produce 3D models of ammonites and the extant Nautilus pompilius and Spirula spirula that were used to reconstruct buoyancy while limiting the amount of necessary geometric assumptions. We developed this method using Nautilus and Spirula to test the accuracy and limitations of 3D volumetrics. Buoyancy calculations of the Nautilus agree with reported observational data from the literature. Subsequent tests calculated the chamber volume of juvenile ammonites and support previous suggestions of a planktonic life-habit for juveniles. These noninvasive methods show strong potential utility in addressing questions of functional morphology and palaeobiology of adult ammonites.

\section{Phylogenetics and biogeography of the woodwardioid ferns, including species from Himalaya [oral presentation]}

\section{Li Chunxiang ${ }^{-1}$ Yang Qun ${ }^{1}$}

${ }^{1}$ Chinese Academy of Sciences, Nanjing Institute of Geology and Palaeontology, State Key Laboratory of Palaeobiology and Stratigraphy, Nanjing, P. R. of China; E-mail: cxli@nigpas.ac.cn

The woodwardioid ferns are well-represented in the Northern Hemisphere. They are disjunctly distributed throughout the warm temperate and subtropical regions of North America, Europe, and Asia. To infer the biogeographical history of the woodwardioid ferns, the phylogeny of Woodwardia was estimated using rbcL and rps4 sequences from divergent distribution regions including species from Himalaya. Phylogenetic results support Woodwardia as a monophyletic group with Woodwardia areolatae and W. virginica as basal. These two species from eastern North America diverged early, which are sister clades to the remaining species from America, Europe, and Asia. Based on analyses on fossil records and divergence time estimations, Woodwardia species were estimated to have diverged first in the Paleogene in North America. After its New World origin, a greater diversification and expansion of Woodwardia occurred in eastern Eurasia, with the European 
arrival of Woodwardia radicans at $13.78 \pm 6.54 \mathrm{Ma}$ during the Middle Miocene. However, compared to earlier reports, a migration back into North America via the Bering land bridge could be suggested.

\title{
Radiation patterns of early Cambrian Small Shelly Fossils (SSFs) in South China [keynote presentation]
}

\section{Li Guoxiang ${ }^{1}$}

${ }^{1}$ Chinese Academy of Sciences, Nanjing Institute of Geology and Palaeontology, State Key Laboratory of Palaeobiology and Stratigrapby, Nanjing, P. R. of China; E-mail: gxli@nigpas.ac.cn

The abrupt appearance of SSFs in the lower Cambrian is one of the major hallmarks of the Cambrian Explosion. South China has been one of the most important regions for studying the diversity and radiation patterns of early Cambrian SSFs. There are only several genera of skeletal fossils in the Ediacaran, and the sharp contrast in bilaterian diversity between the Ediacaran and the early Cambrian records is very consistent with the hypothesis that the Cambrian Explosion records an explosive diversification of bilaterians. The Meishucunian SSF assemblage, dominated by helcionellids, orthothecimorph hyoliths, and other problematic fossils, is very consistent with the concept of the Tommotian Fauna. The Chiungchussian assemblage is mainly characterized by the dominant pan-arthropods and crown-group brachiopods and by a sharp decline in SSF diversity, and it represents an initial phase of the Cambrian Evolutionary Fauna. The decline in SSF diversity after the Meishucunian is not only related to the decimation of some SSFs but also strongly influenced by taphonomic factors.

\section{Late Triassic palynofloras and their palaeoenvironmental significance from Xuanhan of Sichuan Province, southwestern China [oral presentation]}

\author{
Li Liqin ${ }^{1}$, Wang Yongdong ${ }^{1} \&$ Liu Zhaosheng ${ }^{1}$ \\ ${ }^{1}$ Chinese Academy of Sciences, Nanjing Institute of Geology and Palaeontology, Nanjing, P. R. of China; \\ E-mail:ydwang@nigpas.ac.cn
}

The Upper Triassic deposits are well developed in the Sichuan Basin, southwestern China, and are mainly represented by the Xujiahe Formation of the terrestrial coalbearing clastic rocks. This formation is composed of black mudstones, shales and greyish white feldspar-quartz sandstones. The lithological succession of the Xujiahe Formation is quite distinct: the $2^{\text {nd }}$, $4^{\text {th }}$, and $6^{\text {th }}$ members of the formation mainly consist of sandstones; whereas the $3^{\text {rd }}, 5^{\text {th }}$ and $7^{\text {th }}$ members of the formation are dominated by mudstones. 
Recently, a palynological investigation is carried out for the Upper Triassic Xujiahe Formation in Xuanhan County, northeastern Sichuan Basin. The formation is represented by Dictyophyllidites-Cyathidites-Pinuspollenites-Cycadopites (DCPC) assemblage, dating as Rhaetian in age. In this assemblage, the pteridophyte spores are dominant, and gymnosperm pollen is the second abundant group. Some amount of bryophytes spores and fossil algae are present. Among them, the Dipteridaceae spores are the most abundant spore type, whereas spores of Cyatheaceae affinity are the second abundant type. The disaccate pollen grains of conifers and monolete pollen grains of cycad plants are the dominant type of pollen grains.

With reference to the botanical affinity analysis for the dispersed spores and pollen grains, it is possible to clarify the Late Triassic palaeovegetation feature in Xuanhan region. It is inferred that during the Late Triassic, the vegetation in Xuanhan belonged to tropical-subtropical vegetation type. Ferns are the most abundant group; the Dipteridaceae especially plants are abundant, whereas cycads and conifers are the second group in abundance, and the conifer group show increasing trend in the formation.

The Sporomorph Ecogroup Model (SEG), proposed by the Netherlands palynologists, is applied for the first time in Asia to analyse the palaeoenvironment of the Late Triassic in Xuanhan of Sichuan Province. Four SEG groups have been recognized according to the habitat of the parent plants, including Lowland SEG, Highland SEG, River SEG and Pioneer SEG. The environmental background is reconstructed with the aid of the SEG group variation. It is suggested that, in general, the studied region is represented by the lake-marsh environment in lowland. The lake level gradually decrease from lower to upper part of the formation; the palaeoclimate is dominated by humid and warm condition, belonging to the tropical-subtropical type, but showing a variation trend of becoming cold from the lower to the upper part of the Xujiahe Formation. In particular, two climate fluctuations have been recognized in the $5^{\text {th }}$ and $7^{\text {th }}$ members of the formation, indicating two warm and humid climate events in the Late Triassic. In the uppermost part of the Xujiahe Formation, the climate becomes, however, cold and dry. Further works of SEG should be undertaken in the terrestrial Triassic deposits of the Sichuan Basin and other regions in China to test and verify this palynological-based model for palaeoenvironmental reconstruction.

This study was jointly supported by National Basic Research Program of China (2012CB822003) and Knowledge Innovation Program of CAS (KZCX-2-YW-154).

\section{Lithistid sponge-Calathium patch reefs on the Yangtze Platform: An Early Ordovician metazoan-dominated construction at the dawn of the radiation [oral presentation]}

\section{Li Qijian ${ }^{1}$, Li Yue ${ }^{2} \&$ Wolfgang Kiessling ${ }^{1}$}

${ }^{1}$ Friedrich-Alexander University Erlangen-Nürnberg, Geo-Center of Northern Bavaria, Section Palaeoenvironmental Research, Erlangen, Germany; E-mails: qijianli@hotmail.com \& wolfgang.kiessling@grn.uni-erlangen.de 
${ }^{2}$ Chinese Academy of Sciences, Nanjing Institute of Geology and Palaeontology, Nanjing, P. R. of China; E-mail:yueli@nigpas.ac.cn

The lithistid sponge-Calathium bioherms from the Yangtze Platform, South China Block, are among the pioneering metazoan-dominated reef communities in the Early Ordovician. However, the internal structure of their biofabrics and the role of Calathium have remained unclear up to now. We document lithistid spongeCalathium reefs from the Hunghuayuan Formation (late Tremadocian-early Floian) at Huanghuachang in Hubei and at Zhangzhai in Guizhou Province. We first describe their three-dimensional framework and unique accumulation feature of in situ skeletons in detail. The reef cores are characterized by a scaffold structure composed of crowded Calathium and lithistid sponges together with microbial boundstones and bioclasts. The framework differs from the microframes in the contemporaneous calcimicrobial mounds that are more common in the same formation. At the dawn of the Ordovician Radiation, these small-scaled patch reefs represent the initial rebound for skeletal-dominated bioconstructions after the late Early (Stage 4) Cambrian metazoan reef crisis.

\title{
Fossil liverworts from Inner Mongolia, China, and their biogeo- graphic significance [oral presentation]
}

\author{
Li Ruiyun ${ }^{1}$, Sun Bainian ${ }^{1} \& \mathbf{W u}$ Jingyu $^{1}$ \\ ${ }^{1}$ Lanzhou University, School of Earth Sciences, Key Laboratory of Mineral Resources in Western China (Gansu \\ Province), Lanzhou, P. R. of China; E-mail: Liruiyun19861025@163.com
}

The bryophytes, especially the liverworts, are considered the earliest divergent land plants. Fossil bryophytes are important in shaping the paleoecosystem in Earth's history, and are significant in understanding the origin and evolutionary history of land plants and terrestrial ecosystems. They are widespread around the world during the Phanerozoic and have been reported to record the paleo- $\mathrm{CO}_{2}$ levels and climate change. There has been a steady increase in the number of liverwort fossils reported from various geological formations in many countries. But many fossil records are incomplete because of the delicate texture of this group.

Recently, we collected some liverwort fossils from a gray fine-grained sandstone bed of the Lower Coal Member of the Huolinhe Formation in an open-cast mine about $8 \mathrm{~km}$ northeast of Huolinhe City, Inner Mongolia, China. The Early Cretaceous Huolinhe Formation unconformably overlies the volcanic rock of the Xing'anling Group and underlies the Quaternary sediments. It is divided into six lithologic members, in ascending order, sandy conglomerate, lower mudstone, lower coal-bearing member, upper mudstone, upper coal-bearing member, and top mudstone member. Many delicate plant fossils have been reported from the Huolinhe Formation. 
According to the detailed analysis and comparisons, a new genus and species Riccites huolinhensis gen. et sp. nov. was erected. One known species, Hepaticites minutus, and three uncertain species, Hepaticites sp. 1, Hepaticites sp. 2, Hepaticites sp. 3, were identified. From these species, Riccites huolinhensis gen. et sp. nov. bears many resemblances to the extant species of the family Ricciaceae. However, the lobed apex shows the difference among the new genus Riccites, the extant genus Riccia and Ricciocarpus, and the fossil genus Ricciopsis. So we set up this new genus. Three specimens of these fossils are almost the same as the species Hepaticites minutus reported from Antarctica. So we assigned them to the known species Hepaticites minutus. The three uncertain species all show more or less resemblances to the liverwort.

The extant liverworts always live in a humid environment, especially the species of the family Ricciaceae. In addition, the liverworts collected from the Huolinhe Formation are relatively diverse. They comprised about $9 \%$ of the within-flora diversity. So we can deduced that the environment in this region was humid.

This work was conducted under the 973 Program of China (No. 2012CB822003); NSFC (No. 41172022), and Specialized Research Fund for the Doctoral Program of Higher Education (Grant No. 20120211110022).

\title{
New material of Solenites (Czekanowskiales) from the Early Cretaceous of southern Jilin, China [oral presentation]
}

\author{
Li Yunfeng ${ }^{1,2}$, Sun Chunlin ${ }^{1,2}$, Chen Feng ${ }^{1,2} \&$ Li Tao $^{1,2}$ \\ IJilin University, Research Center of Paleontology and Stratigraphy, Changchun, P. R. of China \\ ${ }^{2}$ Ministry of Education, Key Laboratory for the Evolution of Past Life and Environment in Northeast Asia, \\ Changchun, P. R. of China; E-mail: clsun@jlu.edu.cn
}

The Lower Cretaceous Yingzuilazi Formation of the Baishan region in southern Jilin, China is a set of continental deposits. Fossil invertebrates, vertebrates and plants have been collected from this formation recently. The fossil plants mainly include horsetail, ferns, ginkgos, czekanowskias and conifers. Here we present new material of Solenites based on the morphology and epidermal structure. They are Solenites baishanensis sp. nov., Solenites gracilis sp. nov. and Solenites sp. The genus Solenites is a very common member of the Czekanowskiales, but the number of known species is low relative to other taxa in the order, and the date on the epidermal structure is not high. This is the first time that fossil plants are reported from the Early Cretaceous Yinzuilazi Formation. The present new material significantly extends the stratigraphic and geographic distribution of Solenites in the Northern Hemisphere. It also improves our understanding of leaf morphology, epidermal characters and diversity of this genus. 


\title{
Lower Triassic conodont and carbon isotope stratigraphy at Mingtang section, Luodian, southern Guizhou [oral presentation]
}

\author{
Liang Lei ${ }^{1}$, Tong Jinnan ${ }^{1}$, Huang Yunfei ${ }^{1} \&$ Tian $\mathrm{Li}^{1}$ \\ ${ }^{1}$ China University of Geosciences, State Key Laboratory of Biogeology and Environmental Geology, Wuban, P. R. of \\ China;E-mail:hefei1234567.happy@163.com
}

The end-Permian mass extinction, as the most extreme biotic crisis in Earth history, killed over $90 \%$ of marine species and altered the marine ecosystem structures from the Palaeozoic Fauna dominated by brachiopods to Mesozoic Fauna dominated by mollusks. The tempo and mechanism of the subsequent recovery from the mass extinction have received more attention in the last decade. The stratigraphic sequence from the late Permian to middle Triassic is thus crucial for understanding the nature of the great transition of the Permian-Triassic crisis and its aftermath.

The Mingtang section is located in the Luodian County, southern Guizhou, and it was at the northern margin of the Great Bank of Guizhou, which evolved from a low-relief bank in the late Permian to a reef-rimmed platform in the Middle Triassic. A series of well exposed Permian-Triassic sections from platform interior to margins across the Great Bank of Guizhou provide unique conditions for a high resolution biostratigraphic study. Here we report a primary study of conodonts and carbon isotopes at the Mingtang Section as a complementarity of the well-known Guandao Section.

The Mingtang Section is about $200 \mathrm{~m}$ south of the Guandao Section and it was in the same facies as the Guandao Section but a little closer to the platform interior. The section is newly uncovered by a country road, and thus the outcrops are continuous and fresh. The upper Permian to Middle Triassic succession is divided into the Dalong, Luolou and Poduan Formations in lithostratigraphy. The Dalong Formation is composed of black-grayish thin-bedded siliceous mudstone and yellow-grayish thin-bedded mudstone. The lower part of the Luolou Formation is predominated by yellow-greyish thin-bedded mudstone, whereas the upper part is characteristic of greyish thick-bedded limestone intercalated with thickbedded breccia limestone. The Poduan Formation comprises the Tubiphytes-boundstone interbedded with breccia limestone. The whole section is systematically sampled for conodont study. A primary study of the conodont samples has retrieved the index forms of at least four zones, including the Hindeosus parvus, Neospathodus dieneri, Ns. triangularis-Ns. homeri, and Nicoraella kockeli zones.

Meanwhile, a high resolution study of carbonate isotopes is also performed at the section. The $\delta^{13} \mathrm{C}$ curve clearly expresses three positive shifts and two negative shifts and is similar to the excursion of carbon isotopes observed at the marine Lower-Middle Triassic sections in South China. Combined with the conodont data and correlated with the Guandao Section, the positive $\delta^{13} \mathrm{C}$ shifts should occur in the middle and late Dienerian, early Spathian and around the Lower-Middle Triassic boundary, respectively, while the negative shifts were in the Smithian and 
middle Spathian. Due to the consistency of the $\delta^{13} \mathrm{C}$ evolution, the carbon isotope excursions are available for stratigraphic subdivision and correlation.

\title{
SEM observation on the most common conchostracans Euestheria luanpingensis from the Daohugou fauna [posterpresentation]
}

\author{
Liao Huanyu ${ }^{1}$, Huang Diying ${ }^{1} \&$ Shen Yanbin $^{1}$ \\ ${ }^{1}$ Chinese Academy of Sciences, Nanjing Institute of Geology and Palaeontology, State Key Laboratory of Palaeobiology \\ and Stratigraphy, Nanjing, P. R. of China; E-mail:frankyliao@sina.cn
}

The Middle Jurassic terrestrial strata have been well-developed in the Ningcheng Basin at the junction of Inner Mongolia, Liaoning and Hebei provinces, NE China. The Daohugou Beds have yielded very abundant and diverse insects, plants and vertebrates. A distinctive feature of the Daohugou rock matrix is it being laden with relatively small conchostracans of Euestheria, but these are absent in the present layers, which instead contain abundant anostracans. The soft parts, eggs and juveniles from Daohugou are significant to the taxonomy, taphonomy, morphology and paleoecology of Euestheria. Euestheria from Daohugou are supposed to be placed into four species, namely Euestheria riliujingensis, E. haifanggouensis, E. jingyuanensis and E. luanpingensis. However, our recent systematic SEM study of carapaces of conchostracans from Daohugou indicates all the individuals display uniform characters. The adult conchostracans from Daohugou are usually elliptical in shape, and some are rounded while laterally compressed, $4-5 \mathrm{~mm}$ in length, armed with nearly 30 growth bands with reticulate ornamentations that arrange in rows at the lower parts of the carapaces. According to these characters, these conchostracans are definitely E. luanpingensis. That is confirmed by the softparts of the conchostracans from both localities. Re-examination of type specimens of E. haifangoouensis, E. jingyuanensis and E. luanpingensis under a scanning electron microscope shows the carapaces of E. jingyuanensis are ornamented with linear, curved, long reticulations, unlike the ordinary reticulations from the other three species. The detailed study of ornamentation of Euestheria is extremely significant to the stratigraphic correlations of the Middle Jurassic strata.

\section{A Devonian cerioid coral from Coqên, Tibet, China [oralpresentation]}

\author{
Liao Weihua ${ }^{1}$, Ji Zhansheng ${ }^{2} \&$ Wu Guichun ${ }^{2}$ \\ ${ }^{1}$ Chinese Academy of Sciences, Nanjing Institute of Geology and Palaeontology, State Key Laboratory of Palaeobiology \\ and Stratigraphy, Nanjing, P. R. of China; E-mail:weihualiao@163.com \\ ${ }^{2}$ Chinese Academy of Geological Sciences, Institute of Geology, Beijing, P. R. of China
}

The well known Qinghai-Tibetan plateau is the largest, youngest and highest plateau on Earth, with an average height of over $4000 \mathrm{~m}$. The highest of several 
peaks on the plateau of over 8000 m elevation, which is Mt Qomolangma (formerly known as Mt. Everest), has an elevation of $8848 \mathrm{~m}$.

Although the widespread Mesozoic marine deposits and Upper Palaeozoic Carboniferous-Permian beds of Tibet have been known for sometime, the more restricted Devonian strata have been much less studied.

Most of the material described here was collected by Ji Zhansheng from Coqên County [Marzle (Coll. No. 081114) and from the west flank of the Zongdui section (Coll. No. 081116)], Tibet. It includes only one genus and one species, namely Argutastrea darwini (Frech).

Formerly, many Devonian cerioid corals were attributed to Hexagonaria Gürich, 1896. However, following restudy of the neotype of the genus, Hexagonaria hexagona from Bensberg, Germany (probably upper Givetian or lower Frasnian), many species of "Hexagonaria" are now assigned to Argutastrea. Hexagonaria is mainly distinguished from Argutastrea by its septa with spindle-shaped dilatation and typical carinae.

The genus Prismatophyllum Simpson, 1900 differs from Argutastrea Crickmay, 1960 by having thinner septa and yardarm carinae. Argutastrea darwini has been reported from Germany (Sötenich, Eifel), Austria (Hochlantsch, Graz), Russia (the Urals) and China (Coqên, Tibet). It indicates a Middle-Upper Devonian (Givetian-Frasnian) age.

\section{Marine, brackish or freshwater? The palaeoecology of the northern Molasse Basin in the late Early Miocene [poster presentation]}

Dorothea Liebl ${ }^{1}$, Lukas Gegg ${ }^{1}$, Sandra Schützinger ${ }^{1}$, Thomas Lechner ${ }^{1}$, Elena Löhr $^{1}$, Stefanie B. R. Penk ${ }^{1}$, Christoph Gierl ${ }^{1}$, Martina Pippèrr ${ }^{1}$ \& Bettina Reichenbacher ${ }^{1}$

${ }^{1}$ Ludwig-Maximilians University, Department of Earth and Environmental Sciences, Section Palaeontology and Geobiology, Munich, Germany; E-mail: b.reichenbacher@lrz.uni-muenchen.de

The late Early Miocene in the S-German Molasse Basin is the time of the Upper Brackish Molasse (OBM). The traditional view of the OBM-palaeogeography assumes (i) that the Upper Marine Molasse Sea has retreated, (ii) a large river (Graupensand-River) has incised from NNW to SSE along the northern margin of the Molasse Basin, and (iii) an ingression from the Swiss Upper Marine Molasse Sea in the valley of the former river has led to the deposition of the brackish Kirchberg Fm. Here we present data from the Kirchberg Fm. of the borehole Lauingen, located in the area of the ancient Graupensand-River, between Ulm and Donauwörth. Based on high-resolution sampling and micropalaeontological study we found ostracod-, mollusc-, and fish assemblages that indicate a tropical marine to estuarine environment with distinctive freshwater influx. We assume that the habitat of the Kirchberg Fm. at Lauingen represents a coastal setting near to the estuary of a forerunner of the present river Egau, which at that time was draining 
from $\mathrm{S}$ to $\mathrm{N}$ from the Swabian Alb in the Molasse Basin. We conclude that the traditional palaeogeographical model of the OBM needs re-consideration and revision.

\section{Kaili Biota: Building a Bridge across the Taphonomic Divide [invited oral presentation]}

Jih-Pai Lin [Lin Ribai ${ }^{1}$

${ }^{1}$ Chinese Academy of Sciences, Nanjing Institute of Geology and Palaeontology, State Key Laboratory of Palaeobiology and Stratigraphy, Key Laboratory of Economic Stratigraphy and Palaeogeography, Nanjing, P. R. of China;

E-mail:jplin@nigpas.ac.cn

The Kaili Formation (Cambrian Series 2-3) in southeastern Guizhou, China contains three types of Fossil Lagerstätten. The Kaili Lagerstätte, occurring in the Orytocephalus indicus Zone (Cambrian Series 3), is one of the most important Burgess Shale-type (BST) deposits in South China, and these Burgess Shale-type taxa, including nonbiomineralizing arthropods, discoidal animals, worms, and algae, are commonly preserved as organic carbon films. Phosphatization is restricted to organo-phosphatic brachiopod shells and internal volatile tissues, such as gut glands. Pyrite pseudomorphs are mainly associated with the preservation of articulated sponges. Based on more recent work and this study, the unit also contains one of the few Cambrian micro-BST deposits (also known as SCFs Small Carbonaceous Fossils) in the world, with rich organic-walled microfossils. Bulk samples are collected from the Kaili Formation above and/or below the FAD of O. indicus at Miaobanpo, Wuliu, Denzhou, Danzhai and Zhuping sections, and prepared with standard palynological methods along with modified acid treatment techniques. Results show that the most common types of SCFs are filamentous algae and acritarchs with small amount of brachiopod fragments, Wiwaxia sclerites and other problematic organic pieces, and SCFs are not restricted to rock intervals that yield BST taxa. Furthermore, Wiwaxia has also been documented from a secondarily phosphatized fossil assemblage in Australia. Therefore, it is one of the few Cambrian fossils that can be found in BST, SCF and SSF - Small Shelly Fossil (or Orsten-type) deposits, allowing us to view the same Cambrian animal group(s) across different taphonomic pathways. On the other hand, finding Parvancorina-like arthropods in Kaili provides a rare chance to examine the animal evolution during the Ediacaran-Cambrian transition. In addition, the third taphonomic window from the limestone interbeds in the lower part of the unit (Cambrian Series 2) yields well-preserved siliceous sponge spicules and organo-phosphatic brachiopod shell fragments recovered from acid residues. This has broadened our understanding on the true fossil diversity and modes of preservation recorded within the Kaili Formation, and increased its potential for global correlation. 


\title{
Late Visean to Serpukhovian Rugose Corals from South China [oral presentation]
}

\section{Lin Wei ${ }^{1}$}

${ }^{1}$ Chinese Academy of Sciences, Nanjing Institute of Geology and Palaeontology, State Key Laboratory of Palaeobiology and Stratigraphy, Nanjing, P. R. of China; E-mail:xiii_ghost@126.com

For a generalized understanding of Late Mississippian rugose coral fauna from South China, two localities (Yashui Section of Guizhou and Chaohu Section of Anhui) have been chosen for study. In total, 30 species belong to 18 genera were recognized. The coral assemblages in both localities show close resemblance, but certain differences are also present. The Chaohu fauna is dominated by large solitary and massive compound corals with rare small fragments of fasciculate ones. All suffered heavy erosion and show traces of periodical water fouling, indicating a relatively high energy environment. The Huishui fauna, on the other hand, consists of various compound corals as well as solitary ones. In respect to their ages, both assemblages suggest the Yuanophyllum zone. The index taxon, Yuanophyllum, occurs from about $30 \mathrm{~m}$ in the Yashui section, and can be found throughout the Hezhou Formation in Chaohu. Aulina rotiformis, the marker for the range from the latest Visean to early Serpukhovian, occurs from as low as $6 \mathrm{~m}$ below the measured base of the Yashui section, while it can only be found in top-most Hezhou Formation in Chaohu. The coral assemblages also correlate well with coeval faunas from Europe.

\section{A new discovery of Caudipteridae from western Liaoning, China [poster presentation]}

\author{
Liu Dongxuㄹ \& Zhou Changfu ${ }^{1}$ \\ 1Shenyang Normal University, College of Paleontology, Shenyang, P. R. of China; E-mail:Idx19860706@126.com
}

For the past few years, some primitive Oviraptorosauria were discovered in the Jehol Biota, the most famous being Caudipteryx and Incisivosaurus, which provide a lot of very important information for the origin and early evolution of Oviraptorosauria. This paper will describe a piece of specimen discovered in the early Cretaceous epoch of western of Liaoning, which belongs to a Caudipteridae skeleton. The fossil is an adult and completely preserved. Its somatotype is the largest in the Caudipteridae. In its anatomy, the specimen has the characteristics of Caudipteryx and Incisivosaurus: the uncinate processes are present, the pubis is antero-ventrally oriented, the obdurate process of the ischium is developed, the number of caudal vertebra is low, the tail end forms a dagger-shape, the third metatarsal is remarkably laterally compressed as in Candipteryx. The maxilla is provided with teeth, the first premaxilla tooth is well-developed as in Incisivosaurus. Otherwise, the new specimen is provided with other characteristics: it has four premaxilla teeth, the 
bilateral premaxilla and nasal are unfused, the dentary are fused, and five sacral vertebrates, the forelimb third digit keep the third and fourth phalanx, and so on. This new specimen has an important meaning for the evolution of this group and rich information on species from the Jehol Biota.

\title{
Correlation of Permian palynological assemblages from the North China Craton and its palaeobiogeographic implications [oral presentation]
}

\author{
Liu Feng ${ }^{1}$ \\ ${ }^{1}$ Chinese Academy of Sciences, Nanjing Institute of Geology and Palaeontology, Nanjing, P. R. of China; \\ E-mail:liufeng@nigpas.ac.cn
}

Permian palynological assemblages and mutual correlations throughout the North China Craton are synthesized, region by region, based on both published literature and the author's works on the Ordos Basin. The palynological correlation shows that most regions of the North China Craton which are assigned to the Cathaysian palaeofloristic province shared similar palynological successions during the Permian, except for some regions in the Northwest China Craton. These regional differrences of palynological successions in the North China Craton are mainly manifested in the appearance of mixed Cathaysian and Subangaran palynological assemblages in Yongchang, Northwest China Craton, since the late Early Permian (Artinskian-Kungurian). It indicates that the Northwest China Craton collided with the Siberia-Kazakhstan blocks (including Junggar block) at that time. Statistical analysis on the Permian palynological assemblages from the North China Craton reveals that gymnosperm pollen (mainly from conifers) obviously increase in abundance from the late Early Permian (Artinskian-Kungurian). The high percentage of gymnosperm pollen is interpreted to have resulted from a combination of some key factors, including northward drift of the North China Craton and arid climate, which was attributed to the continental uplift when the North China Craton is sutured with the Siberia-Kazakhstan blocks. However, the age of gymnosperm pollen dominance in palynological assemblages became gradually younger from northwest to southeast in the North China Craton. Palynological data support the tectonic collision model between the North China Craton and the Siberia-Kazakhstan blocks, with tectonic convergence of these two plates initially occurring in the late Early Permian (Artinskian-Kungurian) near the Northwest China Craton, and continue suturing eastward as the North China Craton rotated counterclockwise relative to the Siberia-Kazakhstan blocks. Because there was no typical Angaran or Subangaran palynomorphs recovered from the southeast part of the North China Craton until the late Late Permian, suturing and rotation of the North China Craton were still not completed at the end of Permian. 


\section{The specimen collection of the Museum of the Institute of Vertebrate Paleontology and Paleoanthropology, Chinese Academy of Sciences [poster presentation]}

Liu Jinyi ${ }^{1}$, Zheng Fang ${ }^{1}$, Geng Binghe ${ }^{1}$, Ma Ning ${ }^{1}$, Chen Jin ${ }^{1}$, Zhang $\mathrm{Wei}^{1}$, Liu Zhongyun $^{1}$, Zhao Zhongyi ${ }^{1}$, Lou Yushan ${ }^{1} \&{\text { Chen } \mathrm{Wei}^{1}}^{1}$

${ }^{1}$ Chinese Academy of Sciences, Institute of Vertebrate Paleontology and Paleoanthropology, Beijing, P. R. of China; E-mail:liujinyi@ivpp.ac.cn

The specimen collection of the Museum of the Institute of Vertebrate Paleontology and Paleoanthropology (IVPP) is a collection center specializing in the fossils of vertebrates and humans, including the bone or stone artifacts of prehistoric humans as well, all discovered in China. It is the largest one in Asia and also one of the most important in the world. It currently contains an estimated 200,000 specimens of all kinds collected since the 1920s. There are around 2300 precious type specimens in the collection.

In order to manage the specimens efficiently, and also facilitate scholars or enthusiasts to access the collection, an online database of our collection is now under construction. At present, about half of the collection, namely 100,000 specimens or more, has been catalogued and digitalized into the database. In the near future, all other specimens of the collection will be added to the database. The database of our collection can now be accessed through the following internet address: http://124.16.247.2:8080/ivppweb/enspecimensearch/.

Recently, a large number of sensational specimens, such as the fossils of feathered dinosaurs and birds collected from Liaoning Province, and those of aquatic reptiles from Guizhou, have been put in storage, in which 100 specimens, at least, have been published as holotypes in the top academic journals such as Science, Nature and the like. These valuable specimens have made such an intensive impact on Vertebrate Paleontology all over the world that more and more research fellows both at home and abroad are fascinated to see them. On average, there are about 70 professional visitors a year. In order to process more and more application requests quickly and effectively, an online application system has been put into use (see http://mdata.ivpp.ac.cn/enbbg/applicationfrom/index.aspx), and the policies or regulations on visiting the collection have also been issued on the web (please see http://mdata.ivpp.ac.cn/enbbg/applicationfrom/rul.aspx). Visiting scholars are highly recommended to fill in the application form in advance and submit it online, and also to review our policies thoroughly on visiting the collection, molding and casting of specimens, and destructive sampling.

In order to increase our collection, our museum has made an extensive cooperation with other museums at home and abroad to exchange specimens or casts. Up to now, over 5000 specimens or casts from other institutions, for example, a cast of Archaeopteryx from the "Museum für Naturkunde Berlin", have been housed in our collection. In the future, the museum will continue to look for 
opportunities to promote specimen or cast exchange, staff training, specimen information sharing, specimen loans between museums and so on.

\section{Oxidation of pyrite by Acidithiobacillus ferrooxidans and Acidithio- bacillus thiooxidans: comparison with abiotic oxidation [oral presentation]}

\section{Liu Wei ${ }^{1} \&$ Zhang Xingliang ${ }^{1}$}

${ }^{1}$ Northwest University, Early Life Institute and Department of Geology, State Key Laboratory of Continental Dynamics, Xi'an, P. R.of China; E-mails: liuw.geo@qq.com \& xzhang69@nwu.edu.cn

Pyrite is the most abundant metal sulfide associated with the earth's surface region. It is ubiquitous to terrestrial sediments, marine environments and submarine hydrothermal vents. Additionally, microbial oxidation of pyrite is not only one of the most common microbial metabolisms but also a major contributor to the environmental problem of acid mine drainage.

During the oxidation experiments, the experimental systems were designed at $28^{\circ} \mathrm{C}$ within different initial $\mathrm{pH}$ values, i.e.: 1.5, 2.0, 2.5, 3.0 and 3.5. Acidithiobacillus ferrooxidans (A.f.) and Acidithiobacillus thiooxidans (A.t.) were mixed in different proportion (pure A.t., A.f:: A.t. $=1 / 1,3 / 1,5 / 1,7 / 1,9 / 1$ and pure A.f.). The dissolved iron concentration and $\mathrm{pH}$ were monitored at intervals during the first month. The surface changes and the secondary mineral deposits were checked by scanning electron microscopy and energy-dispersive spectrometric (SEM-EDS) after 100 days. The Contrast experiments were also designed in abiotic conditions.

The experimental results showed that the dissolved iron concentrations were increased significantly during the oxidation of pyrite in the presence of $A . f$, though the dissolved iron concentrations were very lower both in the abiotic oxidation and pure $A$. $t$. oxidation systems. In pure $A$. $f$. oxidation systems, the highest dissolved iron concentration was corresponding to the initial $\mathrm{pH}$ value of 2.5. The dissolved iron concentrations in the mixed systems were much higher than in pure $A$. f. oxidation systems, which indicated that $A$. $t$. can reinforce the bioleaching ability of $A$. $f$. The hydrogen ion concentrations were also increased during the process; for instance, in the initial $\mathrm{pH}$ value of 2.5, A. f: A.t. $=5: 1$ systems, the final $\mathrm{pH}$ values were even dropped to around 1.5.

SEM examination demonstrated that pyrites were extensively oxidized during the experiments. And there were two types of dissolution pits developed on crystals surfaces, the cracks and the rounded-polygonal pits. The cracks were arranged in two orientations which were set perpendicular to one another. The size of the cracks was varied with $1-20 \mu \mathrm{m}$ in length and $0.2-0.3 \mu \mathrm{m}$ in width. The rounded-polygonal pits were ranging from $1 \mu \mathrm{m}$ to $3 \mu \mathrm{m}$ in diameter. Pits with polygonal (mainly hexagonal) boundaries seemed to be dominant in number. Rounded pits were relatively less abundant but still common. All of the roundedpolygonal pits appeared to be specifically oriented, perpendicularly penetrating into 
the crystal at varying depth. Furthermore, there were lots of jarosite deposited as the secondary minerals around these rounded-polygonal pits, and the cells were even preserved in the pits. It was worth noting that the cracks were preserved both in the biotic and abiotic oxidation systems, but the rounded-polygonal pits were only observed in the biotic oxidation systems. Thus we proposed that $A$.f. oxidized pyrite with the indirect contact mechanism, and formed the roundedpolygonal pits.

\section{Sources and distribution of isoprenoid glycerol dialkyl glycerol tetraethers in sediments from the east coastal Sea of China: Application of GDGT-based paleothermometry in shallow marginal seas [oral presentation]}

Lü Xiaoxia ${ }^{1}$, Yang Huan ${ }^{1}$, Song Jinming 2 , Li Xuegang 2 , Yuan Huamao ${ }^{2}$, Li Ning $^{2}$, Yang Changbing ${ }^{3}$, Yang Yang ${ }^{1}$, Ding Weihua ${ }^{1} \&$ Xie Shucheng ${ }^{1}$

${ }^{1}$ China University of Geosciences, State Key Laboratory of Biogeology and Environmental Geology, Wuban, P. R. of China; E-mail: luxiaox@163.com

${ }^{2}$ China Academy of Sciences, Institute of Oceanology, Qingdao, P. R. of China

${ }^{3}$ The University of Texas, Bureau of Economic Geology, Austin, Texas, U.S.A.

The east coastal sea of China (ECSC) is a shallow marginal sea in the middle latitude region of the western North Pacific. Utilization of glycerol dialkyl glycerol tetraether (GDGT)-based proxies in ECSC sediments requires local calibration because the sediments in the ECSC mainly come from terrestrial input, primarily from discharge of the Yellow and Yangtze (Changjiang) Rivers. These rivers flow through different climate zones with different soil types and therefore carry distinctive GDGTs into the ECSC. We analyzed the distribution of GDGTs in 58 surface sedimentary samples collected from the ECSC, and then examined their sources and the controlling environmental factors. Relative abundance of acyclic GDGT (GDGT V) in the ECSC increases with latitude, whereas relative abundance of cyclic GDGTs decreases with latitude. The fractional abundances of isoprenoid GDGTs significantly correlate with annual and seasonal sea-surface temperatures (SSTs), especially with summer SST. Based on that, we revised the model of $\mathrm{TEX}_{86}{ }^{\mathrm{H}}$ to reconstruct SST more precisely in the ECSC, and proposed a new GDGT-temperature model for predicting summer SST using three isoprenoid GDGT compounds (GDGT IV, GDGT IV', and GDGT VII). These new models have higher precision $\left(\mathrm{R}^{2}=0.93\right)$ than the existing indices in ECSC, leading to a more robust reconstruction of the paleotemperature in Chinese marginal seas. The distributions of SSTs derived from the two models in core sediments from the ECSC provide about 90 -year records, both of which are consistent with that from the NOAA data. The result further suggests that the new models are promising to reconstruct the summer SSTs. 
The research was funded by the "Strategic Priority Research Program-Climate Change: Carbon Budget and Relevant Issues" of the Chinese Academy of Sciences (XDA05030400), and the Special Fund for Basic Scientific Research of Central Colleges, China University of Geosciences (Wuhan) and Research Fund for the Doctoral Program of Higher Education of China (20120145120017).

\section{Possible "keratose" demosponge fossils in Phanerozoic carbonates [oral presentation]}

\section{Luo Cui ${ }^{1}$}

${ }^{1}$ Georg-August University, Geoscience Centre, Department of Geobiology, Göttingen, Germany;

E-mail: cluo@gwdg.de

Sponges are indicated to have a long evolutionary history before Cambrian by a group of multidisciplinary evidences, except indisputable Precambrian fossil records. This is possibly due to the late evolvement of biomineralization in metazoans. The absence of specific spicules invalidates the criteria normally adopted to identify a fossil sponge. And the "Keratosa" (Dictyoceratida, Dendroceratida, Verongida, etc.), the non-mineralized sister group of other siliceous demosponges, were underestimated in their fossilizing potential and poorly understood in paleontology. The only fossil taxon known up to now is the middle Cambrian Vauxia. Here I report fossil structures which may represent "keratose" sponges from Middle Devonian microbialites (Boulonnais, France) and the Lower Muschelkalk (Poland). The Devonian individuals are preserved as iregular automicrite patches, similar to the other reef-dwelling siliceous sponges which being buried in situ in the same rock, but showing calcite-cemented skeletal of fibrous networks instead of spicules. In contrast, the skeletal network of the Triassic samples is only weakly cemented. The diagenetic recalcitrance of the organic skeletons indicated by the later permineralization is accordant with some observations on the decaying processes of modern sponges as well as the recent discovery of chitin in Verongida. The 3D reconstruction based on grinding tomography shows that both of these networks are morphologically similar to the skeleton of "keratose" demosponges.

\section{Late Jurassic-Early Cretaceous radiolarians from the mélange in Gyangze, southern Tibet [oral presentation]}

Luo Hui ${ }^{1} \& \mathbf{X u} \mathrm{Bo}^{1}$

${ }^{1}$ Chinese Academy of Sciences, Nanjing Institute of Geology and Palaeontology, Nanjing, P. R. of China;

E-mail:builuo@nigpas.ac.cn 
There are a lot of chert blocks bearing radiolarian fossils in the mélange sequences exposed in Gyangze area, Southern Tibet. One big chert block is well cropped out on Zhilong section, located at $28^{\circ} 59^{\prime} 14.2^{\prime \prime} \mathrm{N}$ and $89^{\circ} 48^{\prime} 07.3^{\prime \prime} \mathrm{E}$, near the Zhilong village, about $20 \mathrm{~km}$ northeast of Gyangze County, which is composed of a suite of green thin bedded cherts. Abundant and well-preserved radiolarians were extracted from 31 samples collected from these bedded cherts. More than 63 species within 32 genera were recognized up to now. They contain Archaeodictyomitra apiarium, Pantanellium squinaboli, Parvicingula boesii gr., Thanarla pulchra Archaeospongoprumnum patricki, Hemicryptocapsa capita, Sethocapsa kitoi, Stichocapsa pulchella, Archaeodictyomitra minoensis, Eucyrtidiellum pyramis, Archaeodictyomitra cf. chalilovi, Dibolachras tytthopron, Thanarla gutta, Obesacapsula bullate, etc. These radiolarian assemblages can be well correlated with those from UAZone 11 to UAZone 18 found from the west Tethys (Baumgartner et al. 1995), which indicates the late Kimmeridgian (late Jurassic) to earliest Hauterivian (early Cretaceous) age.

The other chert block is cropped out on the lower parts of the Yongla Section, about $1 \mathrm{~km}$ east to the Zhilong section. More than 60 radiolarian species were recognized from the studied samples. They include Pantanellium squinaboli, Archaeospongoprunum patricki, Archaeodictyomitra lacrimula, Pseudodictyomitra leptoconica, Thanarla gutta, Xitus sandovali, Cryptamphorella gilkeyi (Dumitrica), Cryptamphorella clivosa, Hiscocapsa asseni, Hiscocapsa grutterinki, Jacus (?) italicus, Stylospongia (?) titirez, Stichomitra communis Squinabol, Angulobracchia portmanni, etc. This radiolarian assemblage can be compared to the Asseni Zone-Turbocapsula Zone (O’Dogherty 1994), which indicates the Barremian-Aptian age.

One sample collected from an exotic red chert block about $200 \mathrm{~m}$ west to Yongla pass, Gyangze, yields a moderately well-preserved radiolarian fauna. 19 genera and 27 species are recognized from this radiolarian fauna. It is characterized by the co-occurrence of Turbocapsula costata, Crucella gavalai, Hiscocapsa asseni and Stichomitra simplex. This radiolarian fauna is comparable to the Turbocapsula costata subzone or the 6-9 zones (UAZones 95), which indicates the late Aptian age.

This study is supported by the "Strategic Priority Research Program (B)" of the Chinese Academy of Sciences, Grant No. XDB03010102) and by National Basic Research Program of China (2006CB701402) and NSFC Grant (40572007, 40772004, 41072008).

\section{First Early Permian Palaeosol Ecosystem - The Petrified Forest of Chemnitz (Germany) [oral presentation]}

Ludwig Luthardt ${ }^{1}$, Ronny Rößler ${ }^{2}$, Jörg W. Schneider ${ }^{1}$, Ralph Kretzschmar ${ }^{2}$, Mathias Merbitz ${ }^{2}$ \& Anja Hengst ${ }^{1}$

1Technical University Bergakademie Freiberg, Institute of Geology, Department of Palaeontology, Freiberg/Sa., Germany; E-mail: luthardt@mailserver.tu-freiberg.de

2Museum für Naturkunde, Chemnitz, Germany; E-mail: roessler@naturkunde-chemnitz.de 
The Petrified Forest of Chemnitz is an outstanding example of an Early Permian forest ecosystem preserved by an explosive volcanic event. The fossil site represents a 3D-snapshot of a floodplain environment in the Leukersdorf Formation in the Chemnitz Basin, $291 \mathrm{Ma}$ ago.

The substrate of the forest, a two metre thick palaeosol, shows typical features of pedogenesis, e.g. a loss of stratification by bioturbation, intense colour mottling and carbonate nodules. A calcitic cemented horizon is considered to have been formed by groundwater. The upper $40 \mathrm{~cm}$ of the section contain a dense network of horizontal and vertical root adpressions. The root stocks of in situ upright standing trees are often petrified. The fauna is dominated by about one centimetre large gastropods in the upper $40 \mathrm{~cm}$ of the substrate, which were embedded in situ showing an affinity to deadwood. In addition, mm-sized fragments of disarticulated vertebrate bones are common. The highlights in the fossil record are two completely preserved scorpions, embedded a few $\mathrm{cm}$ below the surface in their putative habitat.

\title{
Early divergence dates of demosponges based on mitochondrial genes and optimized fossil calibrations [oral presentation]
}

\author{
Ma Junye ${ }^{1} \&$ Yang Qun ${ }^{2}$ \\ ${ }^{1}$ Chinese Academy of Sciences, Nanjing Institute of Geology and Palaeontology, Department of Micropalaeontology, \\ Nanjing, P. R. of China \\ ${ }^{2}$ Chinese Academy of Sciences, Nanjing Institute of Geology and Palaeontology, State Key Laboratory of Palaeobiology \\ and Stratigrapby, Namjing, P. R. of China; E-mail:qunyang@nigpas.ac.cn
}

Demospongiae, the most diverse sponges, appeared in the fossil record during the early Cambrian about $520 \mathrm{Ma}$. In order to understand their origination and early diversification, we used 12 protein-coding genes of the mitochondrial genome to estimate the divergence time of the major branch of Demospongiae (Porifera) by using the relaxed molecular clock method. Mitochondrial genome phylogeny suggests that the silicification of demosponges apparently evolved more than once in demosponges. We optimized the placement of calibrations in the phylogenetic tree by the method of maximum likelihood, in which the probability distribution of fossil checkpoints (of well established first stratigraphic appearances) is obtained and compared under different settings of fossil calibration. Our dating analyses show that crown groups of Demospongiae (including Homosclerophorida) first diverged about 701 (665-747) Ma, and the earliest silicification in Demospongiae leading to spicular demosponges began about 642 (627-669) Ma, indicating a gap of over 100 million years between the origin of silicification and their first unequivocal appearance of siliceous spicules in the fossil record (520$525 \mathrm{Ma}$ ); the other silicification events in Demospongiae happened about 585 (569-615) Ma (in Plakinidae) and 232 (149-285) Ma (in Chondrida). The phylochronology of Demospongiae shows that all major groups of Demospongiae 
appeared before the Cambrian, slightly earlier or nearly consistent with their fossil records.

\title{
4D Virtopsy and the taphonomy of Geotrypus antiquus from Enspel (Oligocene, Germany) [oral presentation]
}

\author{
Bastian Mähler ${ }^{1}$, Achim H. Schwermann ${ }^{1}$, Michael Wuttke ${ }^{1} \&$ Thomas Martin $^{1}$ \\ ${ }^{1}$ Rheinische Friedrich-Wilhelms-Universität, Steinmann-Institut für Geologie, Mineralogie und Paläontologie, Bonn, \\ Germany; E-mail: bastian.maebler@uni-bonn.de
}

Taphonomic experiments and $\mu$-CT-analyses of extant Talpa provide a closer look into the decay process of small mammals under limnic conditions. First the carcass floated for a few hours at the water surface and afterwards sank down. At the same time, the soft tissues were decomposed by microorganisms and fermentation gas was produced. Consequently, the carcass was bloated and refloated at the water surface. On the $\mu$-CT-images, the volume of the fermentation gas within the carcass could be measured. The higher the temperature, the faster the gas formation and decomposition occurred. With advanced decomposition, the skeleton got successively disarticulated, beginning with the phalanges, and parts of the floated specimen were scattered. These observations were used for a taphonomic analysis of the partial skeleton of a Late Oligocene mole (Geotrypus antiquus) from the Fossil Lagerstätte Enspel in Germany. Upper and lower jaws in occlusion, the presence of distal hand elements and the left femur, as well as the positions of the anterior extremities, indicate that the specimen sank completely articulated to the bottom of the lake without an extended period of floating. After advanced decomposition of soft tissues, some bones were shifted, before the skeleton was finally embedded.

\section{Graptolite Taxonomy - Where are we now? [oral presentation]}

\section{Jörg Maletz ${ }^{1}$}

${ }^{1}$ Freie Universität, Institut für Geologische Wissenschaften, Berlin, Germany; E-mail: yorge@zzedat.fu-berlin.de

Graptolite taxonomy is in a state of flux right now as new information is available on many groups and their phylogenetic relationships, but a current compilation of data does not exist. Therefore, a new version of the 'Graptolite Treatise' is in preparation and will also incorporate information on other fossil hemichordate taxa. The latest version of the 'Graptolite Treatise' is more than 40 years old and is completely out-dated. Since its publication, our understanding of graptolites changed dramatically. Graptolites are now understood as a subclass of the Pterobranchia, a group of hemichordates including the extant genera Atubaria, Cephalodiscus, and Rhabdopleura. The recognition of the modern marine genus Rhabdopleura 
as an extant member of the Graptolithina allows us to reconstruct the graptolites with better reliability. Thus, the $600+$ genera of graptolites have found a home in the modern taxonomic system of animals, and we can say with confidence: 'Graptolites are alive'. The new taxonomy for the Graptolithina is in part based on cladistic analyses, but also has to rely on information from previous taxonomic and evolutionary research.

\section{The Late Jurassic microvertebrate assemblage of Liuhuanggou in the southern Junggar Basin (Xinjiang, Northwest China) [oral presentation]}

Thomas Martin ${ }^{1}$, Alexander O. Averianov [Александр О. Аверьянов; Aleksandr O. Aver'ānov $]^{2}$, Oliver Wings ${ }^{3,4}$ \& Sun Ge ${ }^{5,6}$

${ }^{1}$ Rheinische Friedrich-Wilhelms-Universität, Steinmann-Institut für Geologie, Mineralogie und Paläontologie, Bonn, Germany; E-mail: tmartin@uni-bonn.de

${ }^{2}$ Russian Academy of Sciences, Zoological Institute, St. Petersburg, Russia; E-mail: dz̧arakuduk@mail.ru

${ }_{3}^{3}$ Hannover State Museum, Hannover, Germany; E-mail:dr.wings@gmail.com

${ }^{4}$ Museum of Natural History, Berlin, Germany

${ }^{5}$ Ministry of Education, Key Laboratory for the Evolution of Past Life and Environment in Northeast Asia, Changchun, P. R. of China

6Shenyang Normal University, Paleontological Museum of Liaoning, Shenyang, P. R. of China;

E-mail: sunge@jlu.edu.cn

The Liuhuanggou locality within the Late Jurassic (Oxfordian) Qigu Formation in the southern Junggar Basin has produced a rich microvertebrate assemblage. The bonebed has yielded a large amount of bones and teeth of aquatic and terrestrial vertebrates, such as hybodontid sharks, actinopterygians, temnospondyles, lissamphibians, xinjiangchelyid turtles, squamates, crocodyliforms, dinosaurs, pterosaurs, and mammals that indicate fluvio-lacustrine conditions in a terrestrial environment. The mammal assemblage is of particular interest because it is the most diverse of Late Jurassic age in Asia. It is similar to the Asian Middle Jurassic mammal assemblages of Berezovsk (Russia) and Sarykamyshsai (Kyrgyzstan) as well as of Kirtlington in Great Britain. The Liuhuanggou assemblage is dominated by docodonts and comprises the eleutherodontid haramiyid Sineleutherus, the docodonts Dsungarodon and Tegotherium, an undetermined eutriconodont, and the stemzatherian Nanolestes. Most remarkable is the lack of dryolestidans and multituberculates, which are important faunal elements in Western European and North American Late Jurassic sites. 


\title{
Evidence for the Valanginian (Lower Cretaceous) Weissert Event in the Boreal Realm [oral presentation]
}

\author{
Philipp Meissner ${ }^{1} \&$ Jörg Mutterlose ${ }^{1}$ \\ ${ }^{1}$ Rubr University, Institute of Geology, Mineralogy and Geophysics, Bochum, Germany; \\ E-mail:Pbilipp.Meissner-f4w@rub.de
}

We present the first detailed stable isotope data $\left(\delta^{18} \mathrm{O}, \delta^{13} \mathrm{C}\right)$ for the Valanginian (Lower Cretaceous) of the southern Boreal Realm. The observations are based on the geochemical analysis of 290 belemnite rostra from stratigraphically well-dated sections in northwest Germany. A major positive carbon isotope excursion (CIE) of $\sim 2 \%$ occurring in the early late Valanginian documents a perturbation of the carbon cycle. This positive CIE, which is well known as the "Weissert Event" in the Tethys, is also displayed in composite carbon isotope records based on published and own data from three different palaeolatitudes $\left(35^{\circ}, 45^{\circ}, 65^{\circ}\right.$ North). These findings suggest that the environmental changes are synchronous, thereby indicating a global control.

The combined oxygen isotope data sets show long-term fluctuations of up to $7^{\circ} \mathrm{C}$ with a cooling in the late Valanginian for the southern and Arctic Boreal Realm, while Tethyan data document rather stable temperatures.

This study highlights the amplitude of the environmental perturbations which occurred in the Valanginian and support that a combination of regional and global factors caused these shifts.

\section{The Frozen Garden of Eden: Vertebrate Palaeontology in the James Ross Basin, Antarctica [oral presentation]}

\author{
Thomas Mörs ${ }^{1} \&$ Marcelo Reguero ${ }^{2}$ \\ 'Swedish Museum of Natural History, Department of Palaeobiology, Stockholm, Sweden; \\ E-mail: thomas.moers@nrm.se \\ ${ }^{2}$ Museo de La Plata, División Paleontología de Vertebrados, La Plata, Argentina; \\ E-mail: regui@fcnym.unlp.edu.ar
}

Today, Antarctica is the only continent with a complete lack of terrestrial vertebrates, and Antarctic seas are inhabited by a small number of vertebrates which are adapted to the extreme conditions. In the geologic past, climatic conditions were very different, and palaeontology is an important tool to reconstruct environments, biodiversity and biogeography. Field work in Antarctica is restricted to $3 \%$ of icefree surface of the continent. Thus, our knowledge about Antarctica's geologic past still is rather scarce. The James Ross Basin east of the Antarctic Peninsula is the only place in Antarctica which exposes Paleogene strata, allowing a keyhole view on high latitude biodiversity and palaeoecology before the final break-off of Gondwana by the separation of South America from Antarctica - and the thermal 
isolation of the entire continent. The shallow seas of the James Ross Basin were inhabited by sharks, rays, chimaerans, bony fishes, leather-back turtles, penguins and early whales; and birds, marsupials (of both Australian and South American origin), gondwanatheres, xenarthrans, and large ungulates lived in the forest environments of the Peninsula.

\title{
Digital inventory of palaeontological objects in natural history collections - Best practises [oral presentation]
}

\section{Alexander Mudroch ${ }^{1}$ \& Ute Richter ${ }^{1}$}

${ }^{1}$ NaTourWissen Ltd., Hannover, Germany; E-mail: amudroch@natoumissen.de

Several years of experience as an external service provider and multiple projects in the field of digital inventory of diverse geoscientific objects, e.g. hand rock samples, core pin samples, oriented specimens of fossils and minerals, have lead to advanced and adapted methods of digitalization and information retrieval in old natural history collections. Streamlining all connected work processes is crucial for success of those costly and time-consuming projects. Teams of two or three trained workers are capable to inventory a large number of objects within a rational time frame, if basic data capture into a database and digital photography of objects $(2 \mathrm{D} / 3 \mathrm{D})$ is strictly separated. A golden rule is to spend as little time as necessary with the real objects in the collection and as much time as possible with the databases that preserve the information. Often the inventory database that is filled during primary data capture phase is mistaken for the final collection catalogue that holds all the information available for an object. One leads to the other, but these two databases, though related, have to serve different needs and are therefore rather different. Most time consuming problems in digital archiving projects happen quite early during A/D conversion of object data and are caused by errors related to the man-machine interface. But the more time you spend, the more money you need. Keep your approach simple, straightforward and well structured in two or three distinct work phases, and a digital fossil collection ready to work with is within reach.

\section{NaTourDidact - Transmission of palaeobiological content as a service provided by NaTourWissen Ltd., Hannover, Germany [poster presentation]}

\author{
Alexander Mudroch ${ }^{1}$, Ute Richter ${ }^{1}$ \& Frederik Spindler ${ }^{2}$ \\ ${ }^{1}$ NaTourWissen Ltd., Hannover, Germany; E-mail: amudroch@natourwissen.de \\ ${ }^{2}$ Technische Universität Bergakademie Freiberg, Institut für Geologie, Freiberg/Sa., Germany
}


NaTourWissen Ltd., with a staff of palaeobiological competence, is well suited to explain the complex contents of natural science to guests in modern nature- and geotourism. Attractive and profound didactic material makes understanding easier and is much more entertaining for the common guest with only little knowledge of scientific facts. Entertaining visual presentation of the actual state of knowledge helps to really remember the facts you have heard. Just like a museum (NaTour Museum) Na'TourWissen Ltd. performs as a mediator between scientific research and interested public, and with its products gives everyone the opportunity to experience the excitement to stay at the beating heart of science.

Natural History museums and installations of nature- and geotourism (Geo sites, Nature and Geoparks, game reserves and nature reservations) were provided with special services in the area of nature- and geo-didactics containing the installation of exhibitions, nature trails, and theme walks, the equipment with scientific didactic material like posters and info panels, and professional consultancy and support. Special workshops were designed to communicate not only palaeobiological content but a broad range of interrelated natural scientific information to relevant target groups.

\title{
Testing the evolutionary-arms-race hypothesis for the Cambrian radiation [oral presentation]
}

\author{
$\mathbf{N a} \operatorname{Lin}^{1} \&$ Wolfgang Kiessling ${ }^{1}$ \\ ${ }^{1}$ Friedrich-Alexander University Erlangen-Nürnberg, Geo-Center of Northern Bavaria, Section Palaeoenvironmental \\ Research, Erlangen, Germany; E-mails:Lin.Na@fau.de@Wolfgang.Kiessling@fau.de
}

Previous studies have proposed various feedback mechanisms to explain how ecological factors may have contributed to the Cambrian radiation. Here we test if an evolutionary-arms-race is a plausible trigger. We used a data set of 38,296 faunal occurrences from the Paleobiology Database to analyse global diversity trajectories and to assess the proportion of predators and prey in the Cambrian.

We found that the sampling-standardized diversity of carnivores shows the same temporal trend as that of skeletal organisms. Both trajectories show a dramatic rise from the Fortunian to Cambrian Stage 2. The diversity of skeletal genera shows a peak in stages 3 and 4 and stabilizes at intermediate levels thereafter. The diversity of predators stabilized already in Stage 2. We also observe a contemporaneous increase in the partitioning of diversity among environments and regions suggesting increasing specialization. These patterns suggest that evolutionary-armsrace is a plausible explanation for the Cambrian radiation. Predators might have disturbed ecological equilibrium, stimulating specialization and species richness and increasing the complexity of community structures. 


\title{
Gastropods at the end-Permian mass extinction [oral presentation]
}

\author{
Alexander Nützel ${ }^{1}$ \\ ${ }^{1}$ Bayerische Staatssammlung für Paläontologie und Geologie, München, Germany; \\ E-mail:a.nuetzel@lrz.uni-muenchen.de
}

Gastropods are present in many Late Palaeozoic and Triassic marine biota. It has previously been emphasized that the end-Permian mass extinction event did affect gastropods (and bivalves) not as seriously as other invertebrate groups. Moreover, gastropods recovered quickly, and consequently they became one of the most diverse invertebrate clades of the modern fauna. However, the study of wellpreserved Late Palaeozoic faunas shows that gastropods were obviously more important and diverse prior to the extinction than previously assumed. Several diverse and well-preserved Permian and Early Triassic gastropod faunas have been reported in the last 10 years from Japan, China, Timor, Far East Russia, Pakistan and the U.S. Their composition suggests strong shifts, i.e., Triassic gastropod faunas differ markedly from Late Palaeozoic faunas. The new data suggest severe extinction in Gastropoda and a high turn-over with many originations in the Early and Middle Triassic.

\section{Rafting versus benthic colonization: Invasion of oxygen-depleted muds? - An example from the late Mississippian of the Rhenish Massif [posterpresentation]}

\author{
Christian J. Nyhuis ${ }^{1} \&$ Michael R. W. Amler ${ }^{1}$ \\ ${ }^{1}$ University of Cologne, Institute for Geology and Mineralogy, Cologne, Germany; \\ E-mails:cbr.nybuis@googlemail.com\&omichael.amler@uni-koeln.de
}

The Actinopteria Shale is a 1 to $4 \mathrm{~m}$ thick isochronous black shale event in the eastern part of the Rhenish Massif, intercalated in a succession of Late Viséan turbiditic limestones and dark-gray shales within a marine deeper water setting of the Rhenohercynian Kulm Facies. The name 'Actinopteria Shale' refers to regional mass-occurrences of the bivalve Ptychopteria (Actinopteria) lepida (Goldfuss), whose mode of life is mostly interpreted as pseudo-planktic. Traditionally, associated benthic fauna is regarded as allochthonous, derived from the oxygenated water column above the seafloor and dropped post-mortem into the anoxic basinal sediment. Records of rafting epibyssate bivalves attached to plant fragments in overlying shales partly support this assumption. However, first time microfacies analysis revealed a wide range of fine-grained sedimentary layers, comprising sharp erosional contacts and various ichnofabrics. These observations indicate affection of anoxic sediments by short-time oxygenation events, resulting in at least dysoxic conditions. The latter very likely have favored colonization of the nutrient-rich muddy substrate by highly specialized organisms and demonstrate the need of a re- 
interpretation of the environment as well as the mode of life for the associated benthic fauna of the Actinopteria Shale.

\section{Taphonomic pathways and the temporal and environmental distri- bution of late Neoproterozoic-early Phanerozoic exceptional biotas [keynote presentation] \\ Patrick J. Orr ${ }^{1}$ \\ ${ }^{1}$ University College Dublin, UCD School of Geological Sciences, Dublin, Ireland; E-mail:patrick.or@@ucd.ie}

The past twenty five years has seen a remarkable improvement in our understanding of the processes by which exceptional biotas are preserved in the geological record. Replication of non-biomineralised tissues in authigenic minerals under experimental conditions in the laboratory, and, especially, study of the diagenesis of fossils from individual biotas, confirms that a series of recurrent presservational mechanisms (taphonomic pathways) operated during the late $\mathrm{Neo}$ proterozoic-early Phanerozoic interval. The principal mechanisms are 'Orstenstyle' coating and impregnation of cuticular substrates; replication of tissues in calcium phosphate; 'Ediacaran'-style preservation, including 'Flinders Ranges-style' biomat-related pseudomorphing of the outline of organisms; and, preservation as near two-dimensional organic remains in association with authigenic phases such as pyrite and clay minerals (Chengjiang and Burgess Shale-type preservation).

What controls the temporal and environmental distribution of these different taphonomic pathways over the late Neoproterozoic-early Phanerozoic interval remains poorly resolved. The low number of exceptional biotas makes it difficult to assess whether each pathway is a global phenomenon or shows any broad latitudinal, or other palaeogeographic, restriction. There are, however, distinct, and different, temporal trends to each taphonomic pathway. These can, with varying degrees of confidence, be linked to the profound restructuring of the biology and geochemistry of the biosphere over the late Neoproterozoic-early Phanerozoic interval. Thus, the decline of 'Flinders Ranges-style' Ediacaran preservation is a predicted outcome of the 'Agronomic Revolution'. 'Orsten-style' preservation broadly, but not precisely, correlates with a peak of phosphorite deposition about the Ediacaran/Cambrian boundary. Replication of specific tissues in calcium phosphate depends, in part, on their biochemistry in vivo, and is thus, to some extent, decoupled from environmental changes. Burgess Shale-type preservation persists throughout the early Phanerozoic, but shifts over time from various marine settings to near-shore settings characterised by environmental stress. The primary driver was most likely an ecological control, and linked to changes over time in the use of ecospace as the complexity of marine ecosystems increased. 


\title{
Sub/Fossil Resin Inclusion Research: $21^{\text {st }}$ Century Trends and Perspectives [keynote presentation]
}

\author{
David Penney ${ }^{1}$ \\ 'The University of Manchester, Faculty of Life Sciences, Manchester, U.K.; \\ E-mail:david.penney@manchester.ac.uk.
}

Within the last few decades, technological advances such as the internet and new imaging techniques (e.g. computed tomography and synchroton scanning) have revolutionized how we do research in the $21^{\text {st }}$ century. High quality publications resulting from international, interdisciplinary collaborations are now commonplace, though there is still much scope for improvement in certain branches of amber palaeobiology. In this talk I will review some of the most important trends in amber research over the past decade or so and highlight areas deserving of more focused research. Topics covered will include summaries of our current knowledge of palaeodiversity of the major world deposits, important new Cenozoic and Mesozoic amber deposits, palaeo-taxonomy (and over-interpretation of fossil inclusions), advances in imaging technologies, quantitative palaeoecology, extinctions and radiations (including predator-prey co-radiations), molecular palaeobiology, and climate change and biogeography. I will also discuss the potential scientific value of inclusions in copal, a source of sub-fossils that is often considered unimportant due to its relatively young age.

\section{Updated conodont distribution across the Visean/Serpukhovian boundary at the Naqing section, South China [posterpresentation]}

Qi Yuping ${ }^{1}$ \& Tamara I. Nemyrovska [Тамара. I. Немировська; Tamara I. Nemirovs'ka $]^{2}$

\author{
${ }^{1}$ Chinese Academy of Sciences, Nanjing Institute of Geology and Palaeontology, Nanjing, P. R. of China; \\ E-mail:ypqi@nigpas.ac.cn \\ ${ }^{2}$ National Academy of Sciences of Ukraine, Institute of Geological Sciences, Kiev, Ukraine; \\ E-mail:tnemyrov@mail.ru
}

The present study reports upon the conodont succession across the Visean/Serpukhovian boundary interval at the Naqing section, South China. Continuous centimeter-scale sampling of the relatively deep water section in recent years has provided new data for a more detailed biostratigraphy of conodonts across the Visean/Serpukhovian boundary. Three conodont zones were described in ascending order, the Gnathodus bilineatus, Lochriea nodosa and Lochriea ziegleri zones. The evolutionary appearance of the conodont species Lochriea riegleri within the lineage Lochriea nodosa-L. ziegleri is being discussed as the most promising marker for the Visean/Serpukhovian boundary. The FAD of L. ziegleri has been moved down to $60.10 \mathrm{~m}$ above the base of the Naqing section. The correlation of the conodont 
succession across the Visean/Serpukhovian boundary in the Naqing section with other sections in Eurasia is presented.

Both species - L. ziegleri and L. cruciformis - are nearest to the boundary. But L. ziegleri is much more widespread around Eurasia. Abundance of conodonts with many transitions between L. nodosa and L. ziegleri discovered in the Naqing section confirmed the high potential of $L$. ziegleri as the best marker for the definition of the Visean/Serpukhovian boundary.

\title{
Sedimentary and carbon isotopic records of the Devonian- Carboniferous boundary in South China [oralpresentation]
}

Qie Wenkun ${ }^{1} \&$ Wang Xiangdong $^{1}$

${ }^{1}$ Chinese Academy of Sciences, Nanjing Institute of Geology and Palaeontology, State Key Laboratory of Palaeobiology and Stratigraphy, Nanjing, P. R. of China; E-mail:wkqie@nigpas.ac.cn

Significant environmental changes and large perturbations to the global carbon cycle occurred during the Hangenberg Crisis, one of the most severe extinction events of the Phanerozoic. High-resolution carbonate carbon isotope profiles, as well as lithofacies, were generated from three sections in South China (Qilinzhai, Malanbian and Long'an) to better understand the patterns and controls on $\delta^{13} \mathrm{C}_{\text {carb }}$ variations in the Hangenberg Crisis intervals. Sedimentological data record a major regression in the Middle praesulcata Zone, which is represented by extensive sedimentary hiatus, siliciclastic influx, reflux dolomites and limestone-solution breccia in shallow-water platforms throughout South China. This lowstand phase is consistent with low $\delta^{13} C_{\text {carb }}$ values recorded from the Long'an section. All three study sections exhibit a positive shift in $\delta^{13} \mathrm{C}_{\text {carb }}$ during the post-glacial sea-level rise that occurred during the Upper praesulcata Zone. Our data thus suggest that the reduction of terrestrial input of organic matter and a vigorous biological pump in the aftermath of the latest Devonian glaciation may be the main causes of the Hangenberg isotope excursion.

\section{Non-marine ostracod biostratigraphy (Upper Cretaceous-Early Tertiary) of the SK1 (n) borehole, Songliao Basin, northeast China} [oral presentation]

\author{
Qu Haiying ${ }^{1}$, Wan Xiaoqiao ${ }^{1}$ \& Xi Dangpeng ${ }^{1}$ \\ ${ }^{1}$ China University of Geosciences, School of Earth Sciences and Resources, Beijing, P. R. of China; \\ E-mail:qqbhyy_705@163.com
}

High-resolution biostratigraphy has been established by using fossil ostracods from the Cretaceous Continental Scientific Drilling borehole-Songke 1 (north) [SK1 (n)] in the Songliao Basin, northeast China. More than 40 species belonging to 
20 genera were identified and 5 ostracod assemblage zones have been recognized. The assemblage zones in ascending order are: Cypridea gunsulinensis-Mongolocypris magna Assemblage, which is marked by the FO of Ilyocyprimorpha with nodes and spines; Ilyocyprimorpha-Limnocypridea sunliaonensis-Periacanthella Assemblage, which is from the FO of Ilyocyprimorpha with nodes and spines to the FO of Strumosia sp.; Strumosia inandita Assemblage from the FO of Strumosia sp. to the LO of Strumosia inandita; Talicypridea amoena-Metacypris kaitunensis-Ziziphocypris simakovi Assemblage from the FO of Mongolocypris apiculata and Talicypridea amoena to the FO of Ilyocypris sp; and Ilyocypris Assemblage from FO of Ilyoypris sp. to the LO of Ilyocypris bisulata sp. nov. During the deposition of Member 4 and Member 5 of the Nenjiang Formation, ostracods were poorly preserved. It is mostly due to the change of the sedimentary environment. The zonal fossil Ilyocypris of Zone 5 reported previously from the Paleocene was found for the first time in the upper Mingshui Formation in the Songliao Basin. Furthermore, some typical Paleocene charophytes like Neochara and Grovesicabra coexist with Ilyocypris. It is suggested that the age of the Ilyocypris assemblage zone is Paleocene. By intergrating data of charophytes, spores and pollen and magnetostratigraphy, the present work attributes the boundary between the Metacypris kaitunensis-Ziziphocypris simakovi Assemblage and Ilyocypris Assemblage to the Cretaceous-Paleogene boundary. This is a potential type section for the terrestrial $\mathrm{K} / \mathrm{Pg}$ boundary in China.

\title{
Exceptionally complete xinjiangchelyid turtles from the Turpan Basin and their implications for modern turtle origins [oral presentation]
}

\author{
Márton Rabi ${ }^{1}$, Zhou Changfu ${ }^{2}$, Oliver Wings ${ }^{4,5}$, Sun Ge Z $^{2,3}$ \& Walter G. Joyce ${ }^{1,6}$ \\ ${ }^{1}$ Eberbard-Karls University of Tübingen, Department of Geosciences, Tübingen, Germany; \\ E-mail: is₹kenderun@gmail.com \\ 2Shenyang Normal University, Paleontological Institute, Shenyang, P. R. of China \\ ${ }^{3}$ Ministry of Education, Key Laboratory for the Evolution of Past Life and Environment in Northeast Asia, \\ Changchun, P. R. of China \\ ${ }^{4}$ Hannover State Museum, Hannover, Germany \\ ${ }^{5}$ Museum of Natural History, Berlin, Germany \\ ${ }^{6}$ University of Fribourg, Department of Geosciences, Fribourg, Switzerland
}

Turtles are the most common vertebrate fossils in Middle to Late Jurassic deposits of the Turpan Basin, Xinjiang Autonomous Province, China. The most spectacular site is the mass locality of "Mesa Chelonia", which is comprised of a single layer with an estimated number of more than a 1000 individuals. The deposition of this Konzentrat-Lagerstätte is best explained by an unseasonably strong drought and subsequent, short transportation by a debris flow. Preparation of this material produced the largest sample of Asian Jurassic turtles known from a single locality. Detailed osteological study revealed that this sample represents a single, but highly variable species, which has important taxonomic implications. Two stratigraphi- 
cally higher sites yielded further new taxa based on associated skulls and shells. The excellent preservation of these specimens provides us with great insights into the plesiomorphic anatomy of crown-cryptodires, the most diverse group of living turtles, and, together with other Mesozoic taxa from the Junggar Basin, they are particularly relevant for understanding the origin and early divergence of the primary clades of extant turtles.

\section{The ultrastructural construction of Mesozoic ammonoid shell wall [oral presentation]}

\section{Gregor Radtke ${ }^{1}$}

${ }^{1}$ Free University, Institute of Geological Sciences, Berlin, Germany; E-mail: gradtke@zedat.fu-berlin.de

In the last decades, the ammonoid ventral and dorsal shell wall was part of multiple studies, but its ultrastructural construction still keeps some secrets and opportunities for future investigations. The examination of different taxa of Ceratitina (Rudolftruempiceras), Lytoceratina (Eotetragonites, Lobolytoceras), Phylloceratina (Calliphylloceras, Holcophylloceras, Euphylloceras) and Ammonitina (Desmoceras, Puzosia, Umsinenoceras, Neosilesites, Kranaosphinctes, Aspidoceras, Euaspidoceras, Psendowaagenia) proves this. The simple three-layered main shell of most ammonoids is modified in some taxa, e.g.: Purosia develops a shell doubling at the umbilical corner and a high organic bearing outer prismatic layer. Umsinenoceras forms a weak relief out of the outer prismatic layer prior to the development of a wrinkle layer. The varices and constrictions of the Lytoceratina, Phylloceratina and Desmoceratids are formed by a thickening of the middle nacreous layer. Generally, no obvious discontinuity exists, but it seems that some nacreous lamellae wedge out. Eotetragonites is an exception with the formation of the constriction, a new generation of the outer prismatic layer is formed, which is shown in form of a discontinuity of the outer prismatic layer. It is well known that plan spiral ammonoids have a reduced dorsal shell, consisting only of the inner prismatic layer and sometimes an additional outer textured wrinkle layer. For the studied taxa, this opinion can be confirmed. But there are reasons that some other ammonoids develop a complete dorsal shell: so as local secondary formation in Purosia's shell or during late ontogeny of Lobolytoceras or Kranaosphinctes. This modality seems to be a general feature in the family Aspidoceratidae. These different shell structures may have the potential for phylogenetic interpretations. 


\title{
A new finding of a Late Jurassic lizard with soft tissue preservation from Ettling (Solnhofen Archipelago) [oral presentation]
}

\author{
Jens Radtke ${ }^{1}$, Helmut Tischlinger ${ }^{2} \&$ Axel Munnecke ${ }^{1}$ \\ ${ }^{1}$ Friedrich-Alexander University Erlangen-Nürnberg, Geo-Center of Northern Bavaria, Section Palaeoenvironmental \\ Research,Erlangen, Germany; E-mails:je-radtke@t-online.de \& axel.munnecke@gzn.uni-erlangen.de \\ 2Stammbam, Germany; E-mail: btischlinger@online.de
}

During scientific excavations of the Jura-Museum Eichstätt in the lithographic limestones of the quarry in Ettling (Markt Pförring, Bavaria), which started in 2007, a new lepidosaur has recently been found. The outcrop is internationally renowned for its diverse fish fauna with colour preservation. However, the discovery of a terrestrial reptile is a rare exception. Together with a juvenile and a severely weathered, adult turtle, up to now this lizard represents the entirety of all excavated reptiles in Ettling. Preparation under UV light not only increased the visibility of anatomic details of the delicate specimen but in this case also proved the preservation of soft tissue. Structures are visible under UV light even in the eye socket. The specimen also shows enigmatic, probable cartilaginous, structures in the area of the forearm and a regenerated tail. On the skull and the neck, remnants of the scales are preserved.

\section{Mesozoic laetmogonid sea cucumbers (Echinodermata: Holothu- roidea: Elasipodida) [posterpresentation]}

\author{
Mike Reich ${ }^{1,2}$ \\ ${ }^{1}$ Georg-August University, Geoscience Museum and Geopark, Göttingen, Germany; E-mail: mreich@gwdg.de \\ ${ }^{2}$ Georg-August University, Geoscience Centre, Department of Geobiology, Göttingen, Germany
}

Modern laetmogonid sea cucumbers were first recorded from the famous "Challenger" expedition of 1872-1876 and were later reported from nearly all marine deep-water environments. Members of this family are medium-sized with an elongate, more or less cylindrical, gelatinous body and well-defined diagnostic wheels.

A comparative systematic survey of all Mesozoic laetmogonid holothurians and their relatives is presented. A re-examination of the fossil record shows that only 14 taxa can be recognised as belonging to this group. Four additional formerly described 'laetmogonid' taxa can be regarded as incertae sedis. Nearly all of these were reported from Europe and India.

At first glance, one might conclude that the fossil record of Mesozoic Laetmogonidae and relatives is quite good. However, a more thorough review reveals numerous gaps and discrepancies. So far, nothing is known about the timing of divergence of elasipodid families and relationships within the Elasi- 
podida. This is in part caused by missing detailed descriptions and SEM studies of modern wheel-shaped ossicles within elasipodid holothurians.

\section{Sea pens (Octocorallia) from the Eocene London Clay, England [posterpresentation] \\ Mike Reich ${ }^{1,2}$ \\ ${ }^{1}$ Georg-August University, Geoscience Museum and Geopark, Göttingen, Germany; E-mail: mreich@gwdg.de \\ ${ }^{2}$ Georg-August University, Geoscience Centre, Department of Geobiology, Göttingen, Germany}

Pennatulacean octorals, or sea pens, are a highly specialised group of anthozoan coelenterates, inhabiting marine areas over a broad range of depths, from the intertidal to the abyssal. These benthic sessile organisms are adapted exclusively for living partly imbedded in coarse to fine sediments. Today, the sea pen fauna worldwide comprises more than 200 extant species in nearly 40 genera of 15 families.

A few dozen isolated pennatulacean axes have been investigated from various localities of the London Clay. This formation, Ypresian in age, is well-developed in the London and the Hampshire Basin as well as in other places in southeastern England, and contains a rich fauna and flora.

Since the appearance of $A$ monograph of the British Fossil Corals by Henri Milne Edwards and Jules Haime in 1850, descriptions, figures, and mentions of Graphularia wetherelli (named after the first collector Nathaniel Thomas Wetherell, 1837; type species of $G$.) have been published by several authors. However, no modern revision of this type species of Graphularia exists, which hinders progress in resolving the systematic status of this genus, which is considered tentative. Various authors (e.g., Bayer, Voigt and others) stated that members of the fossil genus Graphularia are related to the Virgulariidae.

Recently used scanning electron microscopy for documenting the microstructure of the axis surface revealed that Graphularia wetherelli resembles the axial structure of the Pennatulidae, especially of Pennatula. At least, Pennatula? wetherelli comb. nov. is common in Early Eocene strata of England, but is definitively not the only sea pen species widespread in these strata.

\section{First Santonian (Late Cretaceous) holothurians (Echinodermata) from Spain [posterpresentation]}

Mike Reich ${ }^{1,2} \&$ Jörg Ansorge ${ }^{3}$

${ }^{1}$ Georg-August University, Geoscience Museum and Geopark, Göttingen, Germany; E-mail: mreich@gwdg.de

${ }^{2}$ Georg-August University, Geoscience Centre, Department of Geobiology, Göttingen, Germany

${ }^{3}$ Ernst-Moritz-Arndt University, Institute for Geography and Geology, Greifswald, Germany;

E-mail: ansorge@uni-greifswald.de 
Santonian holothurians have so far been mentioned only from Germany and the U.K. - unfortunately, without any descriptions.

The Sierra del Montsec, situated in the southern marginal zone of Pyrenees, presents classical outcrops and excellent preserved fossils of early and late Cretaceous age. Among them disarticulated sea cucumber material, which we recently discovered at Font de la Plata (Lleida, Catalonia, Spain). Our investigations resulted in the identification of at least six holothurian taxa, belonging to the Apodida (Synaptidae, Chiridotidae), Molpadiida (?stem group Molpadiidae), and Aspidochirotida (Holothuriidae), including three new genera (Cruxopadia, Eoleptosynapta, Eorynkatorpa) and four new species (Cruxopadia reitneri, Eoleptosynapta jaumei, Eorynkatorpa catalonica). The new fauna increases our knowledge of holothuroid echinoderms from Santonian strata worldwide.

\title{
Pannychiid sea cucumbers - basal members of the Elasipodida (Echinodermata: Holothuroidea)? [poster presentation]
}

\author{
Mike Reich ${ }^{1,2}$, Niki Davey ${ }^{3}$, Sadie Mills ${ }^{3} \&$ Tanja R. Stegemann ${ }^{1,2}$ \\ ${ }^{1}$ Georg-August University, Geoscience Museum and Geopark, Göttingen, Germany; \\ E-mails:mreich@gwdg.de \& tstegem@gwdg.de \\ ${ }^{2}$ Georg-August University, Geoscience Centre, Department of Geobiology, Göttingen, Germany \\ ${ }^{3}$ National Institute of Water and Atmospheric Research (NIW A), 'Coasts and Oceans', Auckland, New Zealand; \\ E-mails:Niki.Davey@niwa.co.nz@sadie.Mill@@niwa.co.nz.
}

Modern elasipodid holothurians are among the most common members of the deep sea fauna, playing in part an important role at bathyal, abyssal and hadal depths. The group comprises more than 100 extant species belonging to 24 genera and 4 families. However, the fossil history of the Elasipodida is poorly understood and the relationships and branching order of families within the Elasipodida is still unresolved.

Within elasipodid holothurians, the Laetmogonidae with distinct wheel-shaped skin ossicles (e.g., Benthogone, Laetmogone, Pannychia), is the best supported group. Using data from detailed SEM investigations and X-ray computed tomography on modern Laetmogone and Pannychia species, we have found that beside the microscopic wheel ossicles also the calcareous ring structure of both genera are clearly distinct without synapomorphic characteristics on family level. Therefore, we propose that Pannychia should be included in its own family (Pannychiidae). The radial calcareous ring elements $(\mathrm{R})$ of Pannychia are unique amongst modern holothurians, in having three anterior prolongations. Furthermore, the large median perforation (for the passage of the radial nerve) of $R$ closely resembles apodid sea cucumbers, and, concerning the calcareous ring, the Pannychiidae probably link Apodida to Elasipodida. At least, the fossil record of pannychiid holothurians, with single findings from Silurian, Devonian, and Cretaceous strata, is also very sparse compared to other elasipodids. 


\title{
Fossils from the natural history collection of Gottfried Wilhelm Leibniz (1646-1716) [poster presentation]
}

\author{
Mike Reich ${ }^{1,2,3}$ \& Alexander Gehler ${ }^{1,3}$ \\ ${ }^{1}$ Georg-August University, Geoscience Museum and Geopark, Göttingen, Germany; E-mail: mreich@gwdg.de \\ ${ }^{2}$ Georg-August University, Geoscience Centre, Department of Geobiology, Göttingen, Germany \\ ${ }^{3}$ Göttingen Academy of Sciences, long-term project "Johann Friedrich Blumenbach - online" of the Union of the \\ German Academies of Sciences and Humanities, Göttingen, Germany; E-mail: agehler@gwdg.de
}

The German mathematician, philosopher and political adviser Gottfried Wilhelm Leibniz (1646-1716) was one of the great thinkers of the seventeenth and early eighteenth century and is known as the last polyhistor or "universal genius".

He made deep and important contributions to the fields of metaphysics, epistemology, logic, philosophy of religion, as well as mathematics, physics, technology, geosciences, jurisprudence, and history. Leibniz also anticipated notions that surfaced much later in philosophy, probability theory, biology, medicine, linguistics and computer sciences. Even in geosciences, by proposing that the earth has a molten core, he anticipated modern geology. Today, Leibniz is often only distinguished for inventing an early calculating machine, and for his independent invention of differential and integral calculus, as well as for his plans of founding the German Academy of Sciences in Berlin.

His fame as a great scientist, philosopher and cosmopolitan - "one of the most powerful spirits of Western civilisation" - had by this time spread all over Europe and he was in correspondence with most of the important scholars of the day.

After his death in 1716, he left a vast amount of published and unpublished contributions to different fields, primarily written in Latin, French and German. The State Library of Hannover holds his written Nacblass - more than 200,000 single pages, including his manuscripts and more than 15,000 letters. Nearly forgotten is his "Cabinet of Natural Curiosities", which was donated by George III, King of Great Britain and Duke and prince-elector of Brunswick-Lüneburg, to his state university in Göttingen, and was transported here together with the mineral collection of Christoph Andreas Schlüter (1668-1743) in 1777. These collections were then integrated into the 'Royal Academic Museum', which was founded in 1773.

One of his principal works on geo- and life sciences is his Protogaea oder Abhandlung von der ersten Gestalt der Erde und den Spuren der Historie in den Denkmaalen der Natur, in which Leibniz formulated his prescient views on earth history problems. The Protogaea, which is an account of the pre-history of our earth, was intended as the preface to his never finished history of the house of Brunswick. As with many of Leibniz' writings, the Protogaea remained in manuscript form during his lifetime. However, the work was published in "bits and pieces": first in the Acta eruditorum (1693), later in his Theodicy (1710), as well as in various letters. The whole manuscript was published in 1749 (in German, translated by Christian Ludwig Scheidt); 200 years later in a second translation by Wolf von Engelhardt 
(German/Latin; 1949). Other translations occurred since the mid-19th century: French (1859, 1993), Portuguese (1997), Spanish (2006) and English (2008). For long time, it was thought that the fossils figured in Leibniz' Protogaea were destroyed in World War II. However, a few fossils were rediscovered while clearing up the Göttingen Geoscience collections in the last decade, which will be presented here.

\title{
The new Otto Jaekel Medal of the Paläontologische Gesellschaft [posterpresentation]
}

\author{
Mike Reich ${ }^{1,2} \&$ Joachim Reitner ${ }^{1,2}$ \\ ${ }^{1}$ Georg-August University, Geoscience Museum and Geopark, Göttingen, Germany; E-mail: mreich@gwdg.de \\ ${ }^{2}$ Georg-August University, Geoscience Centre, Department of Geobiology, Göttingen, Germany; \\ E-mail:jreitne@gwdg.de
}

The Paläontologische Gesellschaft, founded in 1912 in Greifswald, is one of the oldest palaeontological societies worldwide. Its founder and first president (1912-1921) was the famous German palaeontologist Otto Jaekel (1863-1929). Suprisingly, not a single honour or award has been named after Jaekel - the untiring protagonist and 'fighter' for the autonomy of palaeontology in Germany, who was also a manifold personality. However, here we present a short overview on the person "Otto Jaekel", his achievements, activities and his palaeontological, geological and zoological work, as well as the background of this new award of our society.

The Paläontologische Gesellschaft decided early this year to establish this new medal in recognition of its founder, and on the occasion of Otto Jaekel's 150th birthday this year. The first awardees will be Adolf Seilacher (*1925) and the Palaeontological Society of China, which was founded in 1929 - shortly after Otto Jaekel moved to China (1928) and started his new professorship at the National Sun Yat-sen University (Guangzhou).

\section{Holothurian body fossils (Echinodermata) from various Phanerozoic Fossil Lagerstätten: an overview [poster presentation]}

\author{
Mike Reich ${ }^{1,2} \&$ Tanja R. Stegemann ${ }^{1,2}$ \\ ${ }^{1}$ Georg-August University, Geoscience Museum and Geopark, Göttingen, Germany;

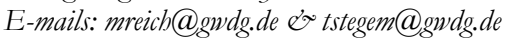 \\ ${ }^{2}$ Georg-August University, Geoscience Centre, Department of Geobiology, Göttingen, Germany
}

The evolutionary history of sea cucumbers (Holothuroidea) remains the most incompletely understood of the five modern classes of Echinodermata. Holothurians have an extremely poor fossil record because their skeleton is usually reduced to microscopic elements that rapidly disarticulate after death. These ossicles of the 
body-wall as well as distinct elements of the calcareous ring surrounding the pharynx are not uncommon in the fossil record and allow us to deduce that the group had evolved by the Middle Ordovician (Darriwilian) and that crown-group divergence had occurred by the Silurian.

Only a dozen of Lagerstätten localities worldwide are known, yielding complete holothurian body fossils. Among them are Konservat-Lagerstätten such as the Hunsrück Slate (Emsian) and the Mazon Creek Essex fauna (Pennsylvanian), as well as different Plattenkalk deposits, like Alcover/Montral (Ladinian), Solnhofen (Tithonian), Tepexí de Rodríguez (Albian), and Hjoûla/Lebanon (Cenomanian), or different obrution deposits like the southern German 'Muschelkalk' (Ladinian) and the Swiss 'Hauptrogenstein' (Bathonian). The preservation, as well as the amount of specimens within each locality, is different. A distinct and clear feature of holothurian body fossils is their calcareous ring. Here we present a comparative systematic survey of all Phanerozoic holothurian body fossils.

\title{
The palaeontological type material of the Göttingen Geoscience collections [posterpresentation]
}

\author{
Mike Reich ${ }^{1,2,3}$, Tanja R. Stegemann ${ }^{1,2} \&$ Alexander Gehler ${ }^{1,3}$ \\ ${ }^{1}$ Georg-August University, Geoscience Museum and Geopark, Göttingen, Germany; \\ E-mail:mreich@gwdg.de \& tstegem@gwdg.de \\ ${ }^{2}$ Georg-August University, Geoscience Centre, Department of Geobiology, Göttingen, Germany \\ ${ }^{3}$ Göttingen Academy of Sciences, long-term project "Johann Friedrich Blumenbach - online" of the Union of the \\ German Academies of Sciences and Humanities, Göttingen, Germany; E-mail: agehler@gwdg.de
}

The Palaeontological Collections within the 'Göttingen Geoscience Museum' are located at the Geoscience Centre of the Georg-August University of Göttingen. These collections have a history of more than 300 years, and the former 'Geological and Palaeontological Museum' was amalgamated with the 'Mineralogical Museum' nearly 15 years ago. Altogether, they are estimated to contain about 4 million specimens and series from all over the world.

Together with other natural history collections in Göttingen, they date back to the foundation of the University in 1734/1737 or have their roots in private and/or royal and aristocratic cabinets. The foundation of the Geoscience Collections was laid by Samuel Christian Hollmann (1696-1787), who was the first external professor appointed at the university in 1734. In 1773, the newly founded 'Royal Academic Museum' included an own department, in which the fossil, mineral, and rock collections were retained. The first acquisitions, including palaeontological objects, were the collections of Christian Wilhelm Büttner (17161801) [in 1773], Gottfried Wilhelm Leibniz (1646-1716), Christoph Andreas Schlüter (1673-1744) [both in 1777], Baron Georg Thomas von Asch (1729-1807) [since 1778], Georg Andreas Stelzner (1725-1802) [in 1781], George III (17381820) King of Great Britain and Ireland, and others, obtained by purchase or 
donation. Among them, numerous specimens collected on scientific expeditions, like the (German-)Danish Arabia Expedition in 1761-1767, the Billings-Saryčev expedition to Siberia and Alaska (1785-1795), Cook's Expeditions to the South Seas (1769-1780), and several others, can be found.

Within the more than 20 partial collections of the 'Göttingen Geoscience Museum', several are related to palaeontology. These collections include around 100,000 type and figured specimes, based on more than 2500 publications.

The fossil invertebrates and vertebrates deposited in our museum were studied and described, and/or donated as single specimens or larger collections, e.g., by Johann Friedrich Blumenbach (1752-1840), Hermann von Meyer (1801-1869), Heinrich Ludolf Wissmann (1815-1892), Adolf von Koenen (1837-1915), Karl von Seebach (1839-1880), Wilhelm Waagen (1841-1900), Wilhelm Barnim Dames (1843-1898), Hermann Rauff (1853-1900), Ernst Koken (1860-1912), Otto Jaekel (1863-1929), Anton Schrammen (1869-1953), Friedrich Freiherr von Huene (1875-1969), Hermann Schmidt (1892-1978), Roland Brinkmann (1898-1995), Walter Robert Gross (1903-1974), Otto Heinrich Walliser (1928-2010), Dieter Meischner (1934-2012), Hans-Peter Schultze (*1937), Reimund Haude (*1939), Joachim Reitner (*1952), and many others.

The Göttingen palaeobotanical type material is mostly based on publications by August Schenk (1815-1891), Constantin Freiherr von Ettingshausen (1826-1897), Hermann Graf zu Solms-Laubach (1842-1915), Henry Potonié (1857-1913), Paul Boguslav Richter (1854-1911), Walter Gothan (1879-1954), Hermann Weyland (1888-1974), Richard Kräusel (1890-1966), Rudolf Florin (1894-1965) and Adolf Straus (1904-1986).

And last but not least, Baltic and Bitterfeld amber inclusions were mostly studied and published by prominent palaeobotanists like Robert Caspary (18181887) and Hugo Conwentz (1855-1922) or entomologists like Theodore Cockerell (1866-1948), Fernand Anatole Meunier (1868-1926), Max Sellnick (1884-1971), Charles P. Alexander (1889-1981), Karl E. Schedl (1898-1979), Willi Hennig (1913-1976), and many others.

\section{New Fossil Lagerstätte Tugen Hills (Kenya, Africa): Exceptional preservation of Miocene freshwater fishes [posterpresentation]}

Bettina Reichenbacher ${ }^{1}$, Cornelia Rasmussen ${ }^{1}$, Stefanie B. R. Penk ${ }^{1} \&$ Melanie Altner ${ }^{1}$

${ }^{1}$ Ludwig-Maximilians University, Department of Earth and Environmental Sciences, Section Palaeontology and Geobiology, Munich, Germany; E-mail: b.reichenbacher@lræ.uni-muenchen.de

Some 3000 species of freshwater fish inhabit the rivers and lakes of modern Africa, but this diversity is not reflected in the fossil record because most of the fossil finds consist of isolated teeth and bones. The Middle to Upper Miocene Ngorora Formation of the Tugen Hills in the Central Kenya Rift (E-Africa) holds fresh- 
water sediments alternating with air-fall tuffs and other volcanic rocks. During our recent fieldwork, we have discovered several sites in the Ngorora Fm. containing excellently preserved articulated fossil fishes (164 specimens). Our first results indicate the presence of three different lake systems at the time of the Ngorora Fm. and a close relationship between explosive volcanism and fish mortality. Several cichlid species are present and may indicate the influx of large river systems from the North and/or West. This leads to the assumption that the topography of the rift shoulders was, at least partially, still low in the Middle to Upper Miocene.

The project is DFG-granted and received important support from the local association of the Orrorin Community Organisation, and from the researchers of Egerton University (Nakuru, Kenya).

\section{Varied $3.5 \mathrm{Ga}$ carbonates on early Earth - microbial mediated mineralization versus hydrothermal origin [oral presentation]}

Joachim Reitner ${ }^{1}$, Jan-Peter Duda ${ }^{1}$, Franziska Wilsky ${ }^{2}$, Nadine Schäfer ${ }^{1}$ \& Martin Van Kranendonk ${ }^{3}$

${ }^{1}$ Georg-August University, Geoscience Centre, Department of Geobiology, Göttingen, Germany;

E-mail:jreitne@gwdg.de

${ }^{2}$ Georg-August University, Geoscience Centre, Department of Isotope Geology, Göttingen, Germany

${ }^{3}$ University of New South Wales, School of Biological, Earth and Environmental Sciences \& Australian Centre for Astrobiology (ACA), Australia; E-mail: martin.vankranendonk@unsw.edu.au

Early Archaean carbonates from the Pilbara (Western Australia, WA) and Barberton Greenstone Belt (South Africa, SA) are almost the oldest known in Earth history, and compositionally variable. Their origin is mostly unclear - formed biologically and/or abiologically. Archaean environments were anoxic and strongly influenced by hydrothermal vents. Few stromatolites (e.g. 3.35 Ga Strelley Pool Fm, WA) are still preserved as a dolomite, indicating microbial growth in the setting. These dolomites are zoned and exhibit strong cathodoluminescence. The cores of the dolomites, however, are non-luminescent and represent the primary precipitate. REE $+\mathrm{Y}$ analyses of dolomite cores (negative Ce \& positive $\mathrm{Y}$ anomaly) show patterns similar to modern microbialites and exhibit $\delta^{13} \mathrm{C}$ VPDB values (ca. $+3 \%$ ) that are in accordance with carbonates deposited through photoautotrophy. These geochemical characteristics are strikingly different to those of hydrothermal carbonates from interpillow cavities (siderite, ankerite in the 3.5 Ga Dresser Fm, WA), which exhibit high $\mathrm{Fe}, \mathrm{Sr}$ and $\mathrm{Ba}$ concentrations, REE+Y pattern typical for a hydrothermal source (positive Eu anomaly), and distinct $\delta^{13} \mathrm{C}$ VPDB and $\delta^{18}$ Osmow values $(-6 \% /+21 \% 0)$. The most intriguing Archaean carbonates, however, are linked to small organic flakes $(100-200 \mu \mathrm{m})$ within Pilbara hydrothermal chert veins and silicified 3.25 Ga sedimentary rocks of the Fig Tree Group (SA). The flakes have $\delta^{13} \mathrm{C}$ VPDB values of ca. $-25-30 \%$ and are commonly associated with small $(10-20 \mu \mathrm{m})$, high-luminescent Mn-rich carbonates, e.g. rhodo- 
chrosite. Hyperthermophile archaea like Pyrobaculum islandicum were reported to be able to reduce $\mathrm{MnO}_{4}$ at $100^{\circ} \mathrm{C}$ while precipitating rhodochrosite (Kashefi \& Lovely 2000). Rhodochrosite and further Mn-rich carbonates (kutnohorite) may therefore be in analogy the product of archaeal activity within the chert veins and silicified Fig Tree sediments. While the validity as a microbial biosignature remains to be proven, multiple lines of evidence argue for early Archaean carbonates as important environmental archives of microbial activity on early Earth.

\title{
Diverse Insects in the Mesozoic Ecosystems from Northeastern China [poster presentation]
}

\author{
Ren Dong ${ }^{1}$ \\ ${ }^{1}$ Capital Normal University, College of Life Science, Beijing, P. R. of China; E-mail: rending@mail.cnu.edu.cn
}

The Mesozoic insects are characteristic of the remarkably high species richness and morphological diversity in the fossil finds of China. We have been conducting research on the Mesozoic insect fossils for more than ten years, and trying to explore the diversity of insects in the Mesozoic ecosystems. Based on our study, we have found more than 170 genera and 360 species from the well-known Jehol biota and Yanliao biota, including one new order and 17 new families. It is suggested that Northeastern China is an important diversification center of insects in the Mesozoic Era. On the basis of the analysis of feeding habit, we considered that the phytophagous insects, pollinators, saprophagous insects and mycophagous insects comprised the basic consumers. Meanwhile, the predaceous insects and parasitic insects could feed on these basic consumers and constituted the secondary consumers. The highest consumers should be dinosaurs, pterosaurs and other big animals that could feed on the insects. As a result, it means the Mesozoic insects endured the heavy pressure of survival and strong natural selection. Numerous specialized insects arose that were fit for the dangerous environments. We found and documented the oldest flower-associated flies that suggested a Jurassic origin of angiosperms. Another discovery revealed an unbeknown pollination mode before angiosperms: the proboscidate scorpionflies pollinated gymnosperms in the Middle Jurassic. The oldest pinnate mimesis and the first documentation of mimicry between insects and ginkgo were found in the Mesozoic, implying a specialized interaction between insects and gymnosperms. We also found the mid-Mesozoic flea-like ectoparsites with extremely large body size that was presumed to have adapted for piercing the contemporaneous hosts.

\section{Isolated theropod teeth from the Late Jurassic (Oxfordian/Kimmerid- gian) of Lower Saxony, NW-Germany [posterpresentation]}

Ute Richter $^{1}$, Alexander Mudroch ${ }^{1} \&$ Lisa G. Buckley ${ }^{2}$ 


\section{Independent Palaeobiologists IIPD, Hannover, Germany; E-mails: richter@iipd.de \& mudroch@ïpd.de \\ ${ }^{2}$ Peace Region Palaeontology Research Centre, Tumbler Ridge, British Columbia, Canada; \\ E-mail:lgbuckley@prprc.com}

Morphometric data of 33 well preserved isolated theropod teeth from the Late Jurassic (Oxfordian/Kimmeridgian) of Lower Saxony, NW-Germany, are acquired according to the method of Smith, Vann and Dodson (2005). All of the teeth belong to the historical collections of Struckmann, Witte, von Koenen and Fischer and were collected during the $19^{\text {th }}$ century in now abandoned limestone quarries near Hanover (districts of Linden and Ahlem) and at other localities in Lower Saxony near the mountains of Hils and Ith (Kahleberg/Echte, Holzen, Marienhagen).

Direct comparison reveals that six different morphotypes (MT 1-6) are present in the material. The teeth of MT 1 to MT 6 all have serrated carinae, and our data analysis indicates that they refer to groups of allosaurid, ceratosaurid, megalosaurid, dromaeosaurid, abelisaurid and carcharodontosaurid theropods.

Our results give new insight into the palaeogeographical distribution of different theropod taxa, especially taxa with Gondwanian affinities like abelisaurids and carcharodontosaurids during the Late Jurassic in Europe. The presence of abelisaurid and carcharodontosaurid theropods was confirmed by other authors for the early Late Cretaceous of Europe.

\section{Palaeolimnological and phylogeographical studies on a Quaternary mega-lake system in the Kalahari, Botswana [oral presentation]}

Frank Riedel ${ }^{1}$, Christian Albrecht ${ }^{2}$, Annette Kossler ${ }^{1}$, Thomas von Rintelen ${ }^{3}$, Mareike Schmidt ${ }^{1}$, Roland Schultheiß ${ }^{4}$ \& Elisha Shemang ${ }^{5}$

'Free University, Institute of Geological Sciences, Berlin, Germany; E-mail:paleobio@zedat.fu-berlin.de

2Justus-Liebig University, Department of Animal Ecology and Systematics, Giessen, Germany;

E-mail: cbristian.albrecht@allzool.bio.uni-giessen.de

${ }^{3}$ Museum für Naturkunde, Leibniz Institute for Research on Evolution and Biodiversity, Berlin, Germany;

E-mail: thomas.rintelen@mfn-berlin.de

${ }^{4}$ University of Turku, Division of Genetics and Physiology, Turku, Finland; E-mail: rolsch@utu.fi

${ }^{5}$ Botswana International University of Science and Technology, Department of Earth and Environmental Sciences, Bontleng Gaborone, Botswana; E-mail: shemange@biust.ac.bw

The Kalahari features a long-lived lacustrine system, the age of which has been speculated on and (palaeo-) limnological parameters have not been documented. We applied a fossil-calibrated molecular clock to the freshwater gastropod Bellamya, and the data suggest that the lake system may have existed since the Early Pleistocene. The emergence of an extant cichlid fish radiation from this (palaeo-) lake during the Middle Pleistocene indicates an ancient lake character. While there is no direct evidence for a mega-lake during Early to Middle Pleistocene, we present data from fluvio-lacustrine palaeo-communities from the Late Pleistocene. With the aid 
of geomorphological studies and analyses of fossil diatoms, molluscs and ostracods, we are able to characterise and model the hydromorphological and palaeolimnological development of the lake system since MIS 5. During repeated highstands, the palaeolake spanned ca. 37,000 $\mathrm{km}^{2}$ comprising freshwater organisms. On the other hand, the lake desiccated at least two times, around ca. $37 \mathrm{ka}$ and during Heinrich Event 1. These strong fluctuations were not only controlled by shifting climate regimes but also by tectonics.

From tidal to mud mound deposits: the archaeocyath-bearing facies in the Cambrian record of Iberia (Western Gondwana margin) [invited oral presentation]

Marta Rodríguez-Martínez ${ }^{1}$, Silvia Menéndez $^{2}$, Elena Moreno-Eiris $^{3}$ \& Antonio Perejón ${ }^{3}$

${ }^{1}$ Universidad Complutense de Madrid, Facultad de Ciencias Geológicas, Departamento de Estratigrafía, Madrid, Spain; E-mail:martarm@geo.ucm.es

2Instituto Geológico y Minero de España IGME, Museo Geominero, Madrid, Spain; E-mail: s.menendez@igme.es ${ }^{3}$ Universidad Complutense de Madrid, Facultad de Ciencias Geológicas, Departamento de Paleontología, Madrid, Spain;E-mails:eiris@geo.ucm.es_o aparqueo@geo.ucm.es

The archaeocyath record from the Iberian Peninsula is represented by ten Spanish Archaeocyath biozones (Perejón \& Moreno-Eiris 2006) from the early Ovetian to Bilbilian (Stage 3 to Stage 4, Cambrian Series 2; ICS 2013). Today, the outcrops are located in four tectonostratigraphic units which are part of the Variscan Iberian Massif (Ossa-Morena, Central Iberian, West Asturian-Leonese and Cantabrian Zones) and in the Paleozoic basement of the Pyrenees. Paleogeographically, the Iberian terrane was located in the western Gondwana margin in subtropical latitudes and both were drifting towards higher latitudes during the Cambrian.

The first onset of archaeocyath-bearing facies sedimentation took place in Cordoba Platform (Pedroche Fm.) and Salamanca-Toledo Platform (Pusa Shales Fm.) in early Ovetian times. Later on, the environmental conditions were suitable for the widespread archaeocyath distribution through other mixed carbonate depositional systems like the Cántabro-Iberian Platform (Transition Beds Fm. and Vegadeo Fm.) and Pyrenees Platform (Evol Fm.) aside from continuing in Cordoba Platform (Pedroche Fm.) and Salamanca-Toledo Platform (Tamames Sandstone and Limestone Fms., and Navalucillos Limestones Fm.). This broad paleogeographic and environmental variability experienced a marked decline during early Marianian time (Stage 4), in which the archaeocyath settlement was restricted to the Alconera Platform (Sierra Gorda and La Hoya Mbs.). Finally, the last occurrence of archaeocyath-bearing deposits took place in the Cantabrian-Iberian Platform (Láncara Fm.) in Bilbilian times (Stage 4).

In the Iberian record, the archaeocyaths displayed exceptional occurrences in cryptic environment during the filling sequence of crevices into Neoproterozoic 
andesites as well as being commonly associated to calcimicrobe thrombolite facies from tidal plains to shelf-margin deposits. The calcimicrobe-archeocyath thrombolites developed characteristic mega- to mesoscale structures in which Girvanella, Renalcis and Epiphyton were the main builders whereas the archaeocyaths played an accessory constructor guild and, only occasionally, Agastrocyathus, Anthomorpha, Archaeocyatbus, Erismacoscinus, Neoloculicyathus, Protopharetra built up clusters of branched frameworks. The architecture of calcimicrobe-archaeocyath thrombolites grades from the simplest macrostructure as isolated, subspherical patches or "head-like-shapes" (15-20 cm wide up to $40 \mathrm{~cm}$ high) up to large decametric bioherms. Additionally and surrounding the shelf-margin bioconstructions, the archaeocyaths were forming para- and autochthonous foreslope assemblages and deposits like carbonate nodules and breccias. In the Cambrian Iberian platforms, the archaeocyaths were mainly associated to calcimicrobe thrombolites, but their singular skeletal contribution to red stromatactis mud mounds is also remarkable.

In most of the above mentioned cases, the archaeocyaths growth was coeval with a moderate to relatively high fine-grained siliciclastic input. In fact, they have been also recorded from siltstones, mudstones and shales.

\title{
The use of Archaeocyaths as an alternative proxy in the recon- struction of Cambrian paleo-seawater REE patterns [poster presentation]
}

\author{
Marta Rodríguez-Martínez ${ }^{1}$, Silvia Menéndez ${ }^{2}$, Elena Moreno-Eiris ${ }^{3}$, Antonio \\ Perejón $^{3} \&$ Joachim Reitner ${ }^{4}$ \\ ${ }^{1}$ Universidad Complutense de Madrid, Facultad de Ciencias Geológicas, Departamento de Estratigrafía, Madrid, \\ Spain; E-mail:martarm@geo.ucm.es \\ 2Instituto Geológico y Minero de España IGME, Museo Geominero, Madrid, Spain; E-mail: s.menendez@igme.es \\ ${ }^{3}$ Universidad Complutense de Madrid, Facultad de Ciencias Geológicas, Departamento de Paleontología, Madrid, \\ Spain;E-mails:eiris@geo.ucm.es@o aparqueo@geo.ucm.es \\ ${ }^{4}$ Georg-August University Göttingen, Geoscience Centre, Department of Geobiology, Göttingen, Germany; \\ E-mail:jreitne@gwdg.de
}

The analyzed archaeocyath-bearing facies is part of the Calizas de los Navalucillos Formation from the Cambrian record of the Central Iberian Zone (Julivert et al. 1972/1974), Montes de Toledo, Spain. The presence of Anthomorpha points out an early Botomian age (Stage 3-Stage 4 transition, Cambrian Series 2, according ICS 2013). Archaeocyaths mainly occur in two lithofacies: (A) massive recrystallized limestones, and (B) carbonate nodules interbedded in cryptocrystalline siltstones. The degree of archaeocyath preservation ranges from moderate (within nodules) to highly recrystallized. Futhermore, the whole set of analyzed facies contains biotite porphyroblasts that were produced under low contact metamorphic degree due to the emplacement of a Variscan granite stock in the vicinity of Consuegra locality, today $13 \mathrm{~km}$ far away. 
Powdered microsamples from archeocyath skeletons, early and late cements, and matrix from different facies were analyzed to check the disturbance of diagenetic, metamorphic and/or later weathering alteration of the original paleo-seawater REE patterns. Major elements were measured with ICP-OES and minor and trace elements were analyzed with ICP-MS.

The total REEs content ranges from 11.5 up to $105 \mathrm{ppm}$ with an average of $49 \mathrm{ppm}$, where $\Sigma \mathrm{REE}_{\mathrm{Urda}} / \Sigma \mathrm{REE}$ PAAs ratios vary from 0.06 to 0.57 with an average of 0.27. The REEs patterns from the different microdrilled samples are very varied, but some of them show a uniform LREE depletion, a slightly negative Ce anomaly, and a relative enrichment of HREE, which are similar characters to those of shale-normalized REE of modern seawater.

\title{
The stabilization of slope deposits by microbial-sponge crusts (Eocene, Ainsa Basin): a potential analogy for some mud mound growth fabrics [poster presentation]
}

Marta Rodríguez-Martínez ${ }^{1}$ \& Joachim Reitner ${ }^{2}$

\author{
${ }^{1}$ Universidad Complutense de Madrid, Facultad de Ciencias Geológicas, Departamento de Estratigrafia, Madrid, \\ Spain; E-mail:martarm@geo.ucm.es \\ ${ }^{2}$ Georg-August University Göttingen, Geoscience Centre, Department of Geobiology, Göttingen, Germany; \\ E-mail:jreitne@gwdg.de
}

The Eocene Ainsa Basin at the southern Pyrenees (northern Spain) is an intraslope mini basin that was connected with the fluvial-deltaic Tremp-Graus Basin towards the southeast and with the deep-water Jaca Basin to the west (Fernández et al. 2004). The Ainsa Basin sedimentary record corresponds to a $4 \mathrm{~km}$ thick succession dominated by deep water slope deposits (San Vicente Fm., Van Lunsen 1970) with several clastic turbidite systems, shallow marine carbonates and fluviodeltaic deposits. The synorogenic fill of the Ainsa Basin has been subdivided into four depositional cycles or Allogroups (Arbués et al. 1988; Muñoz et al. 1988). The analyzed outcrop is part of the San Vicente Fm. (SV3) into the Tierrantona Allogroup (Lutetian), and is located very close to the Boltaña village.

In the western margin of Ara River at the top of the turbidite Gerbe-Banastón System, in a mudstone- to marly-dominated succession, a row of isolated carbonate "boulders", from 70 up to $90 \mathrm{~cm}$ thick, crops interbedded between deep marine marls which pass to thin-bedded mixed sandy-bioclastic turbidites towards the top. The microfacial analysis of these carbonate "boulders" reveals a complex coralgal-sponge/microbial-sponge inter-growth history.

In the upper foreslope, platy thamnasteroid scleractinian corals and coralline sponges Spirastrella (Acanthochaetetes) cf. eocena (Ríos \& Almela) built up small primary framework clusters which were overgrown by Peyssomeliacean (Polystrata? alba)-microencruster bindstones (secondary framework). A first conspicuous bioerosion stage (Entobia and Gastrochaenolites traces) partially destroyed these small 
coralgal-sponge clusters (assemblage A) where large excavating sponges (Aka boltanaensis Reitner \& Keupp) are common. Subsequently to the breakdown and gravitational transport to the downslope site, the coralgal-sponge rubble was extensively colonized by microbial-lithistid sponge crusts (assemblage B) with some overturning episodes and that were affected by a widespread second bioerosion stage, mainly recorded as Gastrochaenolites traces. Finally, the secondary macroboring porosity in microbial-sponge crusts and surrounding firmground sediment (black, dense, low bioclastic, automicrite) was partially colonized and filled by several generations of peloidal accretionary automicrites, allomicrite and cements.

Therefore, a careful microfacial analysis shows that these carbonate "boulders" are not shallow-water, platform derived olistoliths but they share many similarities with mud mound growth fabrics.

\title{
First arthropods from an Early Permian forest ecosystem reveal ecological diversity at the Chemnitz Fossil Lagerstätte (Saxony, Germany) [oral presentation]
}

\author{
Ronny Rößler ${ }^{1}$, Thorid Zierold ${ }^{1}$, Mathias Merbitz ${ }^{1} \&$ Jason Dunlop ${ }^{2}$ \\ ${ }^{1}$ Museum für Naturkunde, Chemnit, Germany; E-mail: roessler@naturkunde-chemnitz:de \\ ${ }_{2}^{2}$ Museum für Naturkunde, Leibniz-Institut für Evolutions- und Biodiversitätsforschung, Berlin, Germany; \\ E-mail:jason.dunlop@mfn-berlin.de
}

A recently (2008-2011) excavated lower Permian (290.6 $\pm 1.8 \mathrm{Ma})$ locality in the Chemnitz Petrified Forest - occurring within the Leukersdorf Formation of the Chemnitz Basin, Germany - provides evidence for an outstanding fossil assemblage buried instantaneously by pyroclastics. This autochthonous deposit preserves the most complete Permian forest ecosystem known to date. Fifty-three trunk bases, still standing upright in their place of growth and rooting in the underlying palaeosol, characterise this Fossil Lagerstätte as a unique window into the past offering insights into a lowland environment sheltering a dense hygrophilous vegetation, as well as a diverse fauna of vertebrates, arthropods and gastropods; several of them are revealed for the first time from the Permian.

Here, we focus on several new arthropods including (1) the youngest record of the extinct arachnid order Trigonotarbida, (2) the first complete scorpion body fossils (Scorpiones) from the Permian, and (3) whip scorpions (Uropygi), millipedes (Diplopoda) and centipedes (Chilopoda). The new finds stem from the Hilbersdorf excavation section and were collected from the uppermost layer of the palaeosol and the lowermost layer of the overlying pyroclastic sequence. The new material comprises several in situ details of the animal's putative habitats, shedding light on their ecology and thus facilitating a reconstruction of this ancient ecosystem. Analysis of the arthropods will not only enhance our understanding of a species-rich forested environment on mineral stands, it will particularly shed light on the spatial heterogeneity, density and synecological relationships within this vol- 
canic influenced environment. Finally, this will add considerably to our view on food chains and evolutionary dynamics within the Early Permian.

\author{
Brasilitherium riograndensis (Brasilodontidae, Cynodontia) reveals \\ new insight into the evolution of the mammalian nasal cavity \\ [oral presentation] \\ Irina Ruf ${ }^{1}$, Wolfgang Maier $^{2}$, Pablo Gusmão Rodrigues ${ }^{3}$ \& Cesar Leandro \\ Schultz ${ }^{3}$ \\ ${ }^{1}$ Rheinische Friedrich-Wilhelms University, Steinmann Institute of Mineralogy, Geology and Palaeontology, Bonn, \\ Germany; E-mail: irina.ruf@uni-bonn.de \\ ${ }^{2}$ Eberhard-Karls University of Tübingen, Department of Biology, Tübingen, Germany; \\ E-mail:wolfgang-maier@uni-tuebingen.de \\ ${ }^{3}$ Universidade Federal do Rio Grande do Sul, Instituto de Geociências, Departamento de Paleontologia e \\ Estratigrafia, Laboratório de Paleovertebrados, Porto Alegre, Brazil; \\ E-mails:pablogr@bol.com.br \& cesar.schultæ@ufrgs.br
}

The mammalian nasal cavity shows several unique features that are correlated with the evolution of endothermic and macrosmatic adaptations. Fossil evidence for the origin of the highly derived characters of the nasal capsule (e.g., turbinates) is lacking, because ossification of these structures seems to have occurred very late in synapsid evolution.

Based on micro CT and virtual 3D reconstructions, we provide the first insight into the nasal cavity of Brasilitherium riograndensis, a derived non-mammaliaform cynodont from the Late Triassic of Southern Brazil. Brasilitherium already shows principal features of the mammalian nasal bauplan. The nasal cavity is posteriorly expanded (ethmoturbinal recesses) and ventrally separated from the nasopharyngeal duct by an ossified posterior transversal lamina, which also incorporates lateral processes of the vomer. The nasoturbinal and first ethmoturbinal are represented by ossified lamellae and distinct ridges on the supporting dermal bones. Brasilitherium has a mesethmoid with lateral impressions of the olfactory nerves and a vomeronasal organ housed within grooves of the premaxillary bones.

\title{
Palaeobiology of the Tentaculitoids from the Lower Devonian Hunsrück Slate (Germany) [oral presentation]
}

Jes Rust ${ }^{1} \&$ Heike Drapatz ${ }^{1}$

${ }^{1}$ Rheinische Friedrich-Wilhelms University, Steinmann Institute of Geology, Mineralogy and Palaeontology, Bonn, Germany; E-mail:jrust@uni-bonn.de

Since their first description the systematic affinity of the tentaculitoids is uncertain and even today their palaeobiology is controversially discussed. In the Hunsrück 
Slate an unusual wide variety of findings of tentaculitoids have been made, allowing new palaeobiological interpretations. Findings of accumulated tentaculitoids turned out to be agglutinated polychaete worm tubes. They were built of small tentaculitoids due to the lack of other available tube components and thus may represent the oldest existing worm tubes built of other organisms. Investigation of tentaculitoid shells associated with larger fossils like mussels, brachiopods, cephalopod shells, and crinoids allowed the postulation of a life-position and conclusions about feeding behaviour and habitat selection. A pelagic way of life for the adult dacryoconarids is rejected in favour of a symbiotic suspension feeding to carrion feeding way of nutrition. The mode of life of tentaculitoids could have resembled that of gastropods and therefore they may indeed be classified as an extinct molluscan taxon.

\title{
Fungi from an Eocene dipterocarp forest [oral presentation]
}

Eva-Maria Sadowski ${ }^{1}$, Christina Beimforde ${ }^{1}$, Heinrich Dörfelt ${ }^{2}$, Matthias Gube ${ }^{2}$, Jochen Heinrichs ${ }^{3}$, Paul C. Nascimbene ${ }^{4}$, Rajendra S. Rana ${ }^{5}$ Joachim Reitner $^{1,6,7}$, Jouko Rikkinen ${ }^{8}$, Nadine Schäfer ${ }^{6}$, Leyla J. Seyfullah ${ }^{1}$, Hukam Singh $^{9} \&$ Alexander R. Schmidt ${ }^{1}$

\author{
${ }^{1}$ Georg-August University, Courant Research Centre Geobiology, Göttingen, Germany; \\ E-mails:eva-maria.sadowski@geo.uni-goettingen.de; christina.beimforde@geo.uni-goettingen.de; jreitne@gwdg.de; \\ leyla.seyfullah@geo.uni-goettingen.de \& alexander.schmidt@geo.uni-goettingen.de \\ ${ }^{2}$ Friedrich-Schiller University, Microbial Communication, Jena, Germany; E-mails: Heinrich.Doerfelt@t-online.de \& \\ Mattbias.Gube@uni-jena.de \\ ${ }^{3}$ Ludwig-Maximilians University, Systematic Botany and Mycology, Munich, Germany; E-mail:jheinrichs@lmu.de \\ 4 American Museum of Natural History, Division of Invertebrate Zoology, New York, N.Y., U.S.A.; \\ E-mail: cedarsap@yahoo.com \\ ${ }^{5}$ Hemwati Nandan Bahuguna Garbwal University, Department of Geology, Srinagar, India; \\ E-mail: rajendra.rana1@gmail.com \\ ${ }^{6}$ Georg-August-Universität Göttingen, Geowissenschaftliches Zentrum, Abt. Geobiologie, Göttingen, Germany; \\ E-mail:nschaef1@gwdg.de \\ ${ }^{7}$ Georg-August-Universität Göttingen, Geowissenschaftliches Museum, Göttingen, Germany \\ ${ }^{8}$ University of Helsinki, Department of Biosciences, Helsinki, Finland; E-mail:jrikkine@mappi.helsinki.ji \\ ${ }^{9}$ Birbal Sahni Institute of Palaeobotany, Lucknow, India; E-mail: bukams@gmail.com
}

The 50 to 52 million-year-old amber deposit of the Gujarat region in western India derives from an early Eocene angiosperm forest that was dominated by trees of the family Dipterocarpaceae. Here, we present three distinct ascomycetes from this highly fossiliferous amber: (1) a mycobiont of an ectomycorrhiza, (2) an anamorph of the genus Monotosporella (Sordariomycetes), and (3) remains of a cladoniform lichen. The mycorrhizal fungus formed the first known fossil ectomycorrhizae associated with an angiosperm and it is preserved adjacent to rootlets of the amber bearing tree. We dissolved amber around one inclusion in order to allow scanning electron microscopy and Raman spectroscopy, which revealed ultrastructural 
features and evidence of fossil fungal melanin, respectively. The inclusion of Monotosporella represents the second fossil record of Sordariomycetes, as well as the first fossil of its particular order (either Savoryellales or Chaetosphaeriales). The specimen is attached to its substrate, which is likely the degraded thallus of a cladoniform lichen.

\section{Palaeoecology of Tethysocarnia cautica and associated micro- encrusters from the Cipit Boulders of the St. Cassian Formation (Lower Carnian, Upper Triassic; Dolomites, Northeastern Italy) [oral presentation]

\author{
Francisco Sánchez-Beristain ${ }^{1}$, Pedro García-Barrera ${ }^{1} \&$ Joachim Reitner ${ }^{2}$ \\ ${ }^{1}$ UNAM, Facultad de Ciencias, Museo de Paleontologia, México, D.F., México; \\ E-mail:sancher@ciencias.unam.mx \\ ${ }^{2}$ Georg-August University Göttingen, Geoscience Centre, Department of Geobiology, Göttingen, Germany; \\ E-mail:jreitne@gwdg.de
}

The Cassian Formation (upper Ladinian to lower Carnian, Middle-Upper Triassic) cropping out in the Southern Alps (Dolomites) of Italy is famous for its ubiquitous palaeontological findings. In particular, the fossiliferous "Cassian Patch Reefs" and the Cassian platforms and their derived erratic blocks, the Cipit Boulders, often exhibit an unusually good preservation. These boulders can be collected at several localities; yet those from the Seelandalpe ("Alpe di Specie") or at Misurina near Cortina d'Ampezzo, are rich in reefal macro- and microfossils.

Recently, important assemblages of microencrusters associated with microbial crusts and sponges have been described. Among others, there is the involutinid foraminafer Tethysocarnia cautica Senowbari-Daryan, Flügel \& Preto. This species has been object of one study, in which only systematic aspects have been reviewed. It has been described for the Ladinian/Carnian (Middle to Upper Triassic) from the whole Palaeotethyan realm, including Hungary, Italy, Slovenia, Greece and Oman. Tetbysocarnia cautica can be seen attached to leiolitic microbialite crusts, and can generally be compared with modern attached calcareous benthic foraminifera that are dominated by trochospiral forms (rotaliids), e.g. Ammonia, Cibicides, Discorbis, Rosalina. Whether Tethysocarnia cautica was permanently attaching or only facultatively is unknown.

\section{Paleoecological adaptations in the forearm of cats [posterpresentation]}

\section{Mayuran Sanmugaraja ${ }^{1} \&$ Rico Schellhorn ${ }^{1}$}

${ }^{1}$ Rheinische Friedrich-Wilhelms University, Steinmann Institute of Mineralogy, Geology and Palaeontology, Bonn, Germany; E-mails: mayuran.sanmugaraja@gmx.de \&o rico.schellhorn@uni-bonn.de 
Extant cats inhabit open landscapes, forests or mountainous regions. The forearm bones reflect adaptations specific to each habitat. Several measurements were taken from the radius and the ulna of different extant felids of which the preferred habitats are known. Plain data were plotted in simple scatter plots. Within these plots, open landscape cats are separated from those inhabiting forests. A factor analysis confirmed these results with clearly separated clusters of both habitat groups. Open habitat felids are more cursorial, having relatively longer and slimmer radii and ulnae, whereas forest inhabitants have relatively shorter and thicker forearm bones. Insufficient data was available for a comparison to the mountain habitat group. The presented methodology has also been applied to published data of different fossil species, e.g. Panthera atrox and Smilodon fatalis from the famous Pleistocene locality Rancho la Brea, to determine their habitats, suggesting a forest habitat for these species.

\section{Metapodial variation in Pleistocene rhinoceros [poster presentation]}

\section{Rico Schellhorn ${ }^{1}$}

${ }^{1}$ Rheinische Friedrich-Wilhelms University, Steinmann Institute of Mineralogy, Geology and Palaeontology, Bonn, Germany; E-mail: rico.schellhorn@uni-bonn.de

Isolated teeth and bones are found in gravel pits of the northern Upper Rhine Plain. These remains of the Pleistocene fauna belong to the last glacial and interglacial period, but a contamination with Holocene material is possible. The large mammal assemblage of both periods comprises giant deer, woolly mammoth, woolly rhinoceros, steppe bison and aurochs, but also cave bear, cave hyena, water buffalo and hippopotamus. Skulls and isolated teeth of rhinoceros show the presence of the woolly rhino (Coelodonta antiquitatis) in the glacial sediments, while the remains from the interglacial period in the gravel pits belong to two species of Stephanorbinus. Isolated metapodials of fore and hind feet have been measured and examined to distinguish at least between the two genera. Because most of the juvenile bones are not recognizable due to an early epiphyseal fusion in metapodials a distinction is difficult. The results show that most of the investigated metapodials probably belong to the more abundant woolly rhino, which therefore indicates a high variation in dimensions of the bones and the size and shape of articulation facets in this species.

\section{The transformation from Gauthieria radiata to Gauthieria princeps (Phymosomatidae) - Heterochrony in the evolution of Cretaceous regular sea urchins [posterpresentation]}

Nils Schlüter ${ }^{1}$ 
${ }^{1}$ Georg-August University, Geoscience Centre, Department of Geobiology, Göttingen, Germany;

E-mail:nscblue@gwdg.de

Phylogenetic approaches in fossil regular echinoids are virtually not available. A study of members of the genus Gautbieria (Phymosomatidae) from the Upper Cretaceous (Turonian-Maastrichtian), based on their ontogenetic development, reveals that the species G. radiata-G. spatulifera-G. princeps form an evolutionary lineage. The main morphological changes within the evolution rely on heterochrony, involving several different heterochronic processes. Their evolutionary trends are predominately related to an increase in size and are thus peramorphic (acceleration); paedomorphic processes (postdiplacement) are found only in G. princeps. The tempo of evolutionary change in this lineage is characterised by rather gradual changes, though in the Campanian, a more abrupt change in tempo of speciation is considered. This study is another example for the importance of heterochrony in morphological diversification, and hence for evolution.

\section{Trap and habitat: microorganisms from tree resin and amber [oral presentation]}

\section{Alexander R. Schmidt ${ }^{1}$ \\ ${ }^{1}$ Georg-August University, Courant Research Centre Geobiology, Göttingen, Germany; \\ E-mail: alexander.schmidt@geo.uni-goettingen.de}

The variety of microorganisms preserved in ambers ranges from micrometre-sized prokaryotic cells and minute unicellular eukaryotes to filamentous algae, extensive fungal mycelia and mushrooms. Thus, ambers provide unique windows to the state of evolution of microbial communities in the amber-rich epochs. Evaluation of microorganisms preserved in amber contradicts a previous notion of a general 'evolutionary stasis' in microbial communities since the Cretaceous. Recent studies rather reveal that some lineages are more stable in their morphology than others and that the composition of the microcoenoses has changed since the Mesozoic. In addition, fresh tree resins and ambers constitute habitats for microorganisms. Bacterial and fungal inclusions are among the most abundant microfossils in ambers, which is due to their frequent ability to grow into liquid and semi-solidified resin. Some representatives of the Mycocaliciales (Ascomycota) are even exclusively found growing on resins and other plant exudates. However, bacteria and fungi also regularly grow into microscopic fissures and cavities of the amber. 


\section{Inside the Clown. Synchrotron X-ray microtomography reveals extra- ordinary details of internal and genital structures of 30 million old beetles [oral presentation]}

Heiko Schmied ${ }^{1}$, Achim H. Schwermann ${ }^{2}$, Thomas van de Kamp ${ }^{3}$, Tomy dos Santos Rolo ${ }^{3} \&$ Tilo Baumbach ${ }^{3}$

${ }^{1}$ Institut für Nutæpflanzenwissenschaften und Ressourcenschutz, Abteilung für Tierökologie, Bonn, Germany; E-mail: schmied@uni-bonn.de

${ }^{2}$ Rheinische Friedrich-Wilhelms-Universität, Steinmann-Institut für Geologie, Mineralogie und Paläontologie, Bonn, Germany

${ }^{3}$ Karlsruber Institut für Technologie (KIT), ANKA/Institut für Photonenforschung und Synchrotronstrablung, Eggenstein-Leopoldshafen, Germany

Almost exclusively three dimensional insect fossils are preserved in amber, which conserves amazing details of the animals. But in most cases only the outer surface of the body is preserved whereas internal structures are lost. A little-known type of three dimensional fossil insects is fissure fillings. A rapid mineralization can happen in a very phosphorus-rich environment like in the Lagerstätte of Quercy (France). This locality is mainly known for remains of terrestrial tetrapods, but some rare specimens of a wide range of fossil arthropods were also found. Many different taxa of Myriapoda, Blattodea, Ensifera, Lepidoptera, Coleoptera, Diptera and Hymenoptera were described by Handschin (1944). A reinvestigation by synchrotron X-ray microtomography revealed extraordinary well-preserved internal structures in a Clown beetle (Onthophilus intermedius, Histeridae), including the genital apparatus. The 3D-reconstructions presented a very detailed view in the intern physiology of a 30 million old insect and show the potential of this nonamber preservation.

\section{Permian-Triassic floral change in Amb, Pakistan [oral presentation]}

Elke Schneebeli-Hermann ${ }^{1}$, Wolfram M. Kürschner ${ }^{2}$, Hans Kerp ${ }^{3}$, Benjamin Bomfleur $^{4}$, Peter A. Hochuli ${ }^{1}$, Hugo Bucher ${ }^{1} \&$ David Ware ${ }^{1}$

${ }^{1}$ University of Zurich, Palaeontological Institute and Museum, Zurich, Switzerland;

E-mail:elke.schneebeli@pim.uzh.ch

${ }^{2}$ University of Oslo, Department of Geosciences, Oslo, Norway

${ }^{3}$ Westphalian Wilhelms University, Institute of Geology and Palaeontology, Münster, Germany

${ }^{4}$ University of Kansas, Natural History Museum and Biodiversity Institute, Department of Ecology and Evolutionary Biology, Lawrence, Kansas, U.S.A.

The impact of the end-Permian extinction event on continents' flora is still debated. Here, we present the palynological record from the shallow marine Permian-Triassic succession in the Amb valley, Salt Range, Pakistan. The residues of the Permian samples yielded, besides palynomorphs, well preserved cuticle fragments. The succession is dated by ammonoids, conodonts, and carbon isotope 
chemostratigraphy. The uppermost Permian assemblages show a mixed Glossopteris-Dicroidium flora. On the Indian subcontinent the corystosperm Dicroidium foliage is reported for the first time from Upper Permian deposits. Griesbachian palynological assemblages are characterised by the regular appearance of lycopod spores while Permian taxa still linger around. Lycopods increase up-section and become dominant in the taxonomically poorly diversified middle Dienerian assemblages. Hence, the record from the Amb valley in the Salt Range reveals a gradual floral change at the Permian-Triassic boundary.

\title{
Taphonomy of arthropods in the Carrizo Arroyo fossil lagerstätte, Early Permian, New Mexico [oral presentation]
}

\author{
Jörg W. Schneider ${ }^{1}$, Spencer G. Lucas ${ }^{2}$, Larry Rinehart ${ }^{2} \&$ Steffen Trümper $^{1}$ \\ ${ }^{1}$ Technical University Bergakademie Freiberg, Institute of Geology, Department of Palaeontology, Freiberg/Sa., \\ Germany; E-mail: Joerg.Schneider@geo.tu-freiberg.de \\ ${ }^{2}$ New Mexico Museum of Natural History, Albuquerque, New Mexico, U.S.A.; E-mail: spencer.lucas@state.nm.us
}

The alluvial siltstone - marine limestone sequences of the Bursum Formation in the Lucero basin, NM, were deposited on a low-gradient coastal plain, occasionally inundated by the sea. In these strata, most arthropod fossils do not occur - as usual - in macro-plant rich layers but on laterally restricted bedding planes covered with fine plant detritus. The most common aquatic components are smooth shelled ostracods, conchostracans, eurypterids of all growth stages, dasyleptids, and bivalves of the Carbonita-group. The terrestrial component consists of diplopods and very common insect fragments. The high-diversity entomofauna consist of more than 30 families. Interestingly, beyond hundreds of wings, only one decayed body fossil of an insect was found. The insect-rich layers are interpreted as deposits of freshwater pools, on the water surface of which the wind-transported insect wings were caught. Because all growth stages of eurypterids were found in these pools, it is assumed that the preferred habitats of these arthropods were freshwater to (?)brackish water environments.

\section{Thunderstorm and catastrophical flood in Morocco - $305 \mathrm{Ma}$ ago [poster presentation]}

Jörg W. Schneider ${ }^{1}$, Hafid Saber ${ }^{2}$, Abouchouaib Belahmira ${ }^{2}$, Frank Scholze ${ }^{1}$, Frederik Spindler ${ }^{1} \&$ Abdelouahed Lagnaoui ${ }^{2}$

1 Technical University Bergakademie Freiberg, Institute of Geology, Department of Palaeontology, Freiberg/Sa., Germany; E-mail:Joerg.Schneider@geo.tu-freiberg.de

${ }^{2}$ Chouaïb Doukkali University, Department of Earth Sciences, El Jadida, Morocco 
A very flat-concave bedding plane of about $10 \mathrm{~m}$ width and minimal $13 \mathrm{~m}$ length in the Stephanian A/B of the Souss basin, Moroccan High Atlas Mts., contains a remarkably low diverse assemblage of plant remains. Dominant are large walchian branches of ca. $25 \mathrm{~cm}$ to $50 \mathrm{~cm}$ length, common are Dychophyllum fronds of ca. $25 \mathrm{~cm}$ length, rare are trunks of up to $45 \mathrm{x} 4 \mathrm{~cm}$ size. The depositional environment of the profile with the plant bearing horizon is determined as a low gradient distal braid plain transitional to lake deposits. The unusual association is interpreted as result of a strong storm event, which broke down the branches and fronds of trees, which were washed together during the waning flood in a pondlike channel cutoff on the braid plain. The association may represent riparian vegetation. Associated flood plain deposits commonly contain tracks of different tetrapods, mainly of pelycosaurs (Dimetropus) and diadectids (Ichniotherium).

\title{
An upgraded carapace terminology for conchostracans [poster presentation]
}

\author{
Frank Scholze $^{1} \&$ Jörg W. Schneider ${ }^{1}$ \\ 'Technical University Bergakademie Freiberg, Institute of Geology, Department of Palaeontology, Freiberg/Sa., \\ Germany; E-mails:frankscholze@yahoo.de \& Joerg.Schneider@geo.tu-freiberg.de
}

Carapace terminologies for conchostracans (Spinicaudata, Crustacea) differ in literature, due to subjective handling by different authors. Therefore, an objective and reproducible terminology is necessary, which uses the following quantitative or semi quantitative criteria: carapace length (extremely small $<1 \mathrm{~mm}$, very small $1-$ $1.5 \mathrm{~mm}$, small $1.5-2.5 \mathrm{~mm}$, middle size $2.5-3.5 \mathrm{~mm}$, big $3.5-4.5 \mathrm{~mm}$, very big $4.5-$ $5.5 \mathrm{~mm}$, extremely big $>5.5 \mathrm{~mm}$ ), carapace shape (ratio height/length; longish oval $<0.6$, oval $0.6-0.75$, round $>0.75$ ), relative dorsal length (ratio dorsal length/total length; very short $<0.5$, short $0.5-0.65$, long $0.65-0.8$, very long $>0.8$ ), relative larval shell size (ratio larval shell height/valve height; very big $>0.7$, big $0.6-0.5$, small $0.4-0.3$, very small $0.2-0.1$ ). The position of the umbo should be determined by data concerning the horizontal (median, submedian, or anterior) and vertical (supramarginal, marginal, or inframarginal) position. A consequent application of a standardized terminology is necessary to avoid subjective diagnoses and synonymies, which limit the use of conchostracans for biostratigraphy.

\section{Multistratigraphic reinvestigation of the Permian-Triassic boundary (PTB) in continental deposits of Central Germany [oral presentation]}

\author{
Frank Scholze ${ }^{1} \&$ Jörg W. Schneider ${ }^{1}$ \\ ${ }^{1}$ Technical University Bergakademie Freiberg, Institute of Geology, Department of Palaeontology, Freiberg/Sa., \\ Germany; E-mails:frankscholze@yahoo.de \& Joerg.Schneider@geo.tu-freiberg.de
}


New multistratigraphic data from PTB sections in Germany include conchostracan biostratigraphy and isotope geochemistry. Basinward deposits of the Calvörde Fm. contain a monospecific fauna of the high variable Euestheria gutta with frequent mass occurrences. The overlying Bernburg Fm. shows a more diverse fauna of spined and radially ripped conchostracans (e.g., Cornia germari, Estheriella nodosocostata). New $\delta^{13} \mathrm{C}$ and $\delta^{18} \mathrm{O}$ data were obtained from oolites and the carbonate cement of sandstones in the Nelben section (Calvörde Fm.). The values of ooids and sandstones range from -5.66 to $-2.38 \%$ for $\delta^{13} \mathrm{C}_{\text {carb }}$ and -9.77 to $-7.65 \%$ for $\delta^{18} \mathrm{O}_{\text {carb }}$. The peaks in the $\delta^{18} \mathrm{O}$ curve of the sandstones show correlations with the amount of carbonate cement. Microfacies analyses prove partial recrystallization of oolites in the horizons $\alpha 1$ and $\alpha 2$. Thus, all isotopic signatures are diagenetically overprinted. Consequently, chemostratigraphic correlations of previous workers need to be reconsidered. For future multistratigraphic investigations more attention should be paid to local variations in bio- and lithofacies, and diagenesis.

\title{
Morphology and variability of enamel islets based on high-resolution computed tomography $(\mu \mathrm{CT})$ - the example of Mylagaulus elassos (Rodentia, Mammalia) [posterpresentation]
}

\author{
Anne Schubert ${ }^{1}$, Irina Ruf ${ }^{1} \&$ Wighart von Koenigswald ${ }^{1}$ \\ ${ }^{1}$ Rheinische Friedrich-Wilhelms University, Steinmann Institute of Mineralogy, Geology and Palaeontology, Bonn, \\ Germany; E-mail: anne.schubert@uni-bonn.de
}

Enamel islets appear in several hypsodont rodent dentitions and possess functional and systematic significance. Yet not much is known about their variability over the complete height of the tooth and the constraints that control the formation.

Based on $\mu \mathrm{CT}$ data, the morphology of enamel islets was studied in 3D reconstructions in ten specimens of Mylagaulus elassos from the Miocene of North America. The occlusal surface of their enlarged P4/p4 consists almost completely of enamel islets.

The islets vary in number and shape in the investigated specimens. Main islets are always present, but additional islets appear. The islets split up proximally; this is not known to this extent from other rodents with enamel islets like Hystrix or Myocastor. This splitting occurs in the investigated teeth with great variability.

In Mylagaulus the islets are elongated. Their length was measured in selected virtual later occlusal surfaces. The shearing blades of the islets increase in length, indicating an increase in functionality, but decrease in late wear stages as in Hystrix or Myocastor. 


\title{
Dental functions of mammaliaforms and early mammals [poster presentation] \\ Julia A. Schultz ${ }^{1}$ \\ ${ }^{1}$ Rheinische Friedrich-Wilhelms University, Steinmann Institute of Mineralogy, Geology and Palaeontology, Bonn, Germany; E-mail:julia.schultæ@uni-bonn.de
}

During mammalian evolution, complex mastication patterns for food reduction evolved by modifying the postcanine teeth and improving the primitive orthal jaw movement. Complex Mesozoic pre-tribosphenic molar types were investigated using striation analysis combined with virtual jaw movement simulation (Occlusal Fingerprint Analyser software) to compare the ability of food reduction. The hypoflexid groove is fundamental for food reduction in dryolestids, while it is less involved in tribosphenids. Striations on dryolestid molars indicate an initial piercingcutting phase followed by a shearing phase, ending in centric occlusion. In tribosphenids, centric occlusion is followed by a grinding phase. Tritylodontid and multituberculate postcanine morphology is triggered by the backward chewing movement. While both herbivore groups show similar occlusal surfaces, different strategies of food break-down were achieved. Particles are cut along a series of blades in tritylodontids, while in multituberculates food is mainly sheared between large areas. It shows that precise occlusion is mandatory for the evolution of the pre-tribosphenic dentitions.

\section{Our knowledge of fossil sarcopterygians and the Chinese contribution [oralpresentation]}

\author{
Hans-Peter Schultze ${ }^{1} \&$ Gloria Arratia ${ }^{1}$ \\ 1The University of Kansas, Natural History Museum, Lawrence, Kansas, U.S.A.; E-mail: hp1937@ku.edu
}

Extant bony fishes comprise two main lineages, Actinopterygii and Sarcopterygii. With about 30,000 species of teleosts, actinopterygians are by far the most dominant group of vertebrates today. Sarcopterygians are successful throughout several tetrapod lineages, and notably one powerful and dominant species, Homo sapiens. While today piscine sarcopterygians are represented by two coelacanth and six dipnoan species, their major diversification was in the past. Due to their phylogenetic importance in the origin of tetrapods, piscine sarcopterygians have been the subject of major investigations starting in the $1^{\text {th }}$ century. The Swedish School and its followers have been fundamental to this development by their new methods and strict working discipline. New phylogenetic methods have changed the approach of the Swedish school. The focus in the last 30-40 years moved to the basal osteichthyans and to Chinese fossils and researchers. Basal dipnoan, coelacanths and tetrapodomorphs have been discovered and placed in the appropriate position. 


\title{
Taphonomy of large cockroach wings of the Hamilton Quarry fossil lagerstätte, Late Pennsylvanian, Kansas [posterpresentation]
}

\author{
Maria Schulz ${ }^{1}$, Jörg W. Schneider ${ }^{1} \&$ Roy Beckemeyr ${ }^{2}$ \\ ${ }^{1}$ Technical University Bergakademie Freiberg, Institute of Geology, Department of Palaeontology, Freiberg/Sa., \\ Germany; E-mail:Joerg.Schneider@geo.tu-freiberg.de \\ ${ }^{2}$ University of Kansas, Division of Entomology, Lawrence, Kansas, U.S.A.; E-mail: royb@southwind.net
}

Generally, the renowned Hamilton Quarry fossil lagerstätte is interpreted as an estuarine depositional environment. Unusual is the nearly monospecific occurrence of wings and complete body fossils of one mylacrid species of about $7 \mathrm{~cm}$ size. They are buried in microbial mat limestone, which show in some layers reworking structures. Besides cockroaches, the fossil content consists of plant detritus, smooth shelled ostracods of the Darwinula-group, and rarely of brachiopod fragments and fusulinids. Lithofacies and biofacies together point to deposition in a protected brackish to freshwater lagoon in the estuary system which was rarely flooded by seawater, possibly during storm-events. The co-occurring insect remains - complete body fossils, isolated fore and hind wings as well as isolated head shields (pronota) - have different drift properties. Therefore, transport selection could not have caused this nearly monospecific assemblage. It is assumed that the very low diverse taphocoenosis reflects a similar low diverse biocoenosis.

\section{Comparative and functional anatomy of the ear region in extinct and extant Rodentia (Mammalia) [poster presentation]}

\author{
Cathrin Schwarz ${ }^{1} \&$ Irina Ruf ${ }^{2}$ \\ ${ }^{1}$ University of Vienna, Department of Palaeontology,Vienna, Austria; E-mail: cathrin.schwar:@univie.ac.at \\ ${ }^{2}$ Rheinische Friedrich-Wilhelms University, Steinmann Institute of Mineralogy, Geology and Palaeontology, Bonn, \\ Germany;E-mail:iruf@uni-bonn.de
}

Based on micro CT data, we compared the anatomy and morphometry of the middle ear region, the auditory ossicles and the bony labyrinth of selected †Theromyidae, †Ischyromyidae, †Cylindrodontidae, and extant species of the squirrelrelated clade (Sciuridae, Gliridae, Aplodontia rufa) in order to elucidate phylogenetic and functional relevant features.

Phylogenetic characters are represented by the malleus and the inner ear, whereas the incus and stapes show a conserved pattern. For the groundplan character state of the middle ear cavity in the squirrel-related clade, a network of bony septa is postulated. By comparative investigations of all investigated species, we suggest a closer relationship between sciurids and glirids, whereas Aplodontia rufa appears to be highly derived.

The anatomy of the semicircular canals is highly influenced by the locomotion mode and thus can be used for elucidating locomotion and agility in fossil species. 
Based on statistic analyses of the investigated extant squirrels, fIschyromys typus is postulated to have been generalistic whereas †Cylindrodon fontis and + Ardynomys occipitalis were most probably arboreal.

\title{
Form and function of the molar dentition of Cretaceous Alphadon (Didelphimorphia, Marsupialia) [oralpresentation]
}

\author{
Achim H. Schwermann ${ }^{1}$, Thomas Martin ${ }^{1} \&$ Ottmar Kullmer ${ }^{2}$ \\ ${ }^{1}$ Rheinische Friedrich-Wilhelms-Universität, Steinmann-Institut für Geologie, Mineralogie und Paläontologie, Bonn, \\ Germany; E-mail: achim.schwermann@uni-bonn.de \\ ${ }_{2}^{2}$ Senckenberg Research Institute and Natural History Museum, Department of Palaeoanthropology and Messel \\ Research, Frankfurt/M., Germany
}

The Cretaceous marsupial Alphadon is known by abundant dental remains from North America. Functional aspects, such as the exposure of dentine, the orientation of wear facets and the relief of lower molars, were investigated quantitatively to get hints for the specific usage of the dentition, respectively the preferred diet. For comparison, the extant didelphimorphs Caluromys (frugivore), Didelphis (omnivore) and Monodelphis (insectivore, carnivore) were studied. All four taxa have a very similar tribosphenic dentition.

The molar occlusal facets of Alphadon are very steep, which is also the case in extant Monodelphis, whereas Didelphis and Caluromys have less steep facets. The Relief Index reflects the height differentiation of the crown as a quotient of the crown surface and its base area. Alphadon lower molars have a relatively high index value between that of extant Didelphis and Monodelphis, whereas the frugivore Caluromys has significantly lower values. This confirms the hypothesis that Alphadon was mainly insectivorous. Monodelphis more closely resembles this basal marsupial taxon than Didelphis in molar wear pattern and functional morphology.

\section{Dental morphotypes and functional differences in early artiodactyl evolution [oral presentation]}

\section{Leonie Schwermann $^{1}$ \& Wighart von Koenigswald ${ }^{1}$ \\ ${ }^{1}$ Rheinische Friedrich-Wilhelms-Universität, Steinmann-Institut für Geologie, Mineralogie und Paläontologie, Bonn, Germany; E-mail: leonie.schwermann@uni-bonn.de}

Diacodexis, the oldest and most primitive artiodactyl, had a relatively less derived tribosphenic bunodont dentition. In the early evolution of artiodactyls, several dental morphotypes occur, differentiated by number, arrangement and morphology of cusps. They lead to the highly derived selenodont dentitions of modern selenodont artiodactyls. The main focus of this study lies on the convergent transitions to selenodont dentitions in early artiodactyls. 
The masticatory movement and functional aspects of the different dental morphotypes were investigated on the basis of wear facets (orientation, striations) on the occlusal surface. The morphological changes of the occlusal surface are quantified by the relief index and a shearing quotient. While the occlusal surface on the one hand becomes more simple regarding the height differentiation (relief index), there is on the other hand an increasing complexity in the development of shearing crests, associated to the selenodont cusp morphology. The masticatory movement changes from a two-phased power stroke to a more simple movement through to the one-phased movement of many modern selenodonts.

\title{
Chaetetids from the Upper Carboniferous Buckhorn Asphalt Quarry Lagerstätte, Oklahoma [posterpresentation]
}

\author{
Barbara Seuss $^{1}$, Baba Senowbari-Daryan ${ }^{1} \&$ Alexander Nützel $^{2}$ \\ ${ }^{1}$ Friedrich-Alexander-Universität Erlangen-Nürnberg, GeoZentrum Nordbayern, Section Palaeoenvironmental \\ Research, Erlangen, Germany; E-mails: barbara.seuss@gzn.uni-erlangen.de dodaryan@gzn.uni-erlangen.de \\ ${ }^{2}$ Bayerische Staatssammlung für Paläontologie und Geologie, München, Germany; \\ E-mail:a.nuetzel@.lr.uni-muenchen.de
}

Chaetetid sponges from the Desmoinesian Buckhorn Asphalt Quarry Lagerstätte represent the largest benthic organisms in this outcrop (max. diameter: $21 \mathrm{~cm}$, max. height: $8.3 \mathrm{~cm}$ ). Deposition of the chaetetid-bearing sediments occurred in a shallow (euphotic zone II-III) marine setting near the palaeo-equator. The siliciclastic-carbonatic sediments from the Lagerstätte were impregnated by migrating hydrocarbons during or shortly after deposition; hence, fossil preservation is generally outstanding.

Chaetetid skeletons from the quarry originally consisted of high Mg-calcite. Two morphotypes are present, comprising domical and laminar growth, which indicates genetic rather than environmental control. Internal skeletal features comprise tabulae, spine-like projections, pseudoseptae, growth disturbances, and greyish structures. Tubule diameter and length is variable, and spicules are absent. Skeletal fragmentation is common and indicates complex taphonomic mechanisms. Some specimens display large incisions indicating physical impact. The skeletal surface is also often covered by microbial mats associated with Mn-carbonatic cements.

\section{Tracing gymnosperms through the Palaeozoic: the road to China [keynote presentation] \\ Leyla J. Seyfullah ${ }^{1}$ \\ ${ }^{1}$ Georg-August University, Courant Research Centre Geobiology, Göttingen, Germany; \\ E-mail: leyla.seyfullab@geo.uni-goettingen.de}


In terms of plants, the Palaeozoic era is marked by terrestrialisation, escalating plants diversity and increasingly complex ecosystems. The earliest plants are characterised as free-sporing and require free water for fertilisation, limiting their ecological ranges. It should not be forgotten that sporing plants have been and remain successful; their descendants are still with us today but, the innovation of the seed habit in the Devonian period freed plants from this need for liquid water for fertilisation, and allowed embryo dormancy for the first time. Thus seed habit can be thought of as the key innovation that allowed these plants to move out to drier environments and establish new niches.

The earliest seed plants are the seed ferns, which comprise a rather heterogeneous group of plants with varying anatomy, morphology and habits. They are best known from the Upper Devonian and Mississippian (lower Carboniferous) deposits of North America and Europe. We can follow the diversification and continued evolution of these plants throughout the Carboniferous and into the early Permian using more European and North American deposits, but the finds become much rarer. Other gymnosperms also evolved during the Palaeozoic, like the cycads, which are thought to have evolved during the Late Palaeozoic. This is also based on North American and European Pennsylvanian (Upper Carboniferous) to Early Permian finds.

What happened to these plants and their habitats during the Permian ? To fill in this gap in our knowledge from the Early Permian onwards, we look to China. Sediments from China have indeed previously provided some of the clearest examples of seed ferns, showing exactly how the seeds were attached to the plants. China today is still providing us with more exciting seed fern finds, including anatomically preserved material and pollen. China also provides us with Permian cycad megasporophylls which appear more similar to today's cycads than the Euamerican finds do. As more work progresses on the Permian fossils from China and new finds shape our ideas, theories are developing about Euamerican floras taking refuge and endemising in the Cathaysian realm.

\title{
An unusual horsetail is a parent plant of Verrucosisporites applanatus spores - a marker of a Middle Triassic age [posterpresentation]
}

\author{
Leyla J. Seyfullah ${ }^{1}$, Evelyn Kustatscher ${ }^{2,3} \&$ Wilson A. Taylor ${ }^{4}$ \\ ${ }^{1}$ Georg-August University, Courant Research Centre Geobiology, Göttingen, Germany; \\ E-mail: leyla.seyfullab@geo.uni-goettingen.de \\ ${ }^{2}$ Museum of Nature South Tyrol, Bolzano, Italy \\ ${ }^{3}$ Ludwig-Maximilians University, Department of Earth and Environmental Sciences, Section Palaeontology and \\ Geobiology, Munich, Germany \\ ${ }^{4}$ University of Wisconsin, Department of Biology, Eau Claire, Wisconsin, U.S.A.
}

Early-early Middle Triassic plant remains are uncommon in Europe, with few floras well documented. The Middle Triassic (Anisian) of Bromsgrove, Worcester- 
shire, UK, provides new insights into the terrestrial biota at this time and is extremely valuable since it provides the majority of fossil plants from the UK terrestrial Triassic sequence. This small but diverse flora comprises typical gymnospermous (Willsiostrobus, Pelourdea) and sphenopterid (Schizoneura, Neocalamites) elements of an Anisian-age flora. Reinvestigation of megafossil remains led to the discovery of a previously unknown and undescribed plant fossil with in situ spores, Bromsgrovia willsii Seyfullah et al. 2013. The in situ spores were extracted and examined by light, scanning electron and transmission electron microscopy. The in situ spores are Verrucosisporites applanatus, a marker for the Middle Triassic. Using the combination of macromorphological and micromorphological features, we show for the first time that a parent plant of $V$. applanatus is a horsetail with an unusual morphology and not a fern as previously thought.

\title{
A new method to determine volume of spiral bromalites: morpho- metrics of Lower Permian (Archer City Formation) heteropolar bromalites [oral presentation]
}

\author{
Christen D. Shelton ${ }^{1}$ \\ ${ }^{1}$ Rheinische Friedrich-Wilhelms University, Steinmann Institute of Mineralogy, Geology and Palaeontology, Bonn, \\ Germany; E-mail: cshelton@uni-bonn.de
}

Lower Permian vertebrates have been collected from Archer County, Texas for over a century. This includes preserved shark cartilage and spiral bromalites presumed to have been produced by freshwater Orthacanthus sharks. Specimens were collected in the newly named Archer City Bonebed V occurring in the Archer City Formation. Physical characteristics (length, width, height, mass, eccentricity, volume, and density) were measured and recorded for 300 spiral bromalites and compared by linear regression analysis. The spiral bromalites had an average length of $31.74 \mathrm{~mm}$; width $14.43 \mathrm{~mm}$; height $10.51 \mathrm{~mm}$, and mass $7.971 \mathrm{~g}$. Eccentricity ranged from 0.9 to 0.06 . All of these values follow a normal distribution. In addition, a new formula is proposed to help determine the volume of these elliptical fossils when volume determination by water displacement is not an option. The percent difference between the observed volumes obtained by water displacement and calculated volumes ranged from $0.04 \%$ to $56 \%$. Ninety five percent of the statistical sample had a percentage difference of less than 30 . This paper is in press.

The oldest known naturally formed tetrapod bone casts and the first bone casts discovered in the Lower Permian (Tambach Formation) Evidence of a larger early Permian bipedal reptile from the Bromacker [posterpresentation] 


\section{Christen D. Shelton ${ }^{1} \&$ Thomas Martens $^{2}$}

${ }^{1}$ Rheinische Friedrich-Wilhelms University, Steinmann Institute of Mineralogy, Geology and Palaeontology, Bonn, Germany; E-mail: cshelton@uni-bonn.de

2Museum der Natur, Gotha, Germany; E-mail: ursauriermartens@t-online.de

The earliest known bipedal reptile comes from the Lower Permian, Tambach Formation, near Gotha, Germany and the village of Tambach-Dietharz: Eudibamus cursori. Evidence for bipedal animals from the Lower Permian of Thuringia were first described as foot prints preserved in the Tambach Sandstone (TSS) that were hypothesized to have been produced by a then unknown bipedal reptile (Tambachichnium schmidti). Here, we report the first evidence of vertebrate remains preserved in the TSS in the form of natural bone casts from at least two different species, one being bipedal and gracile. In addition, these are also the oldest known preserved tetrapod bone casts ever to be discovered. The slab $(2.25 \mathrm{~m} \mathrm{x} 1.65 \mathrm{~m})$ containing the bone casts also has mud cracks, raindrops, and Tambia spiralis preserved on the surface. 29 possible vertebrate remains were identified from at least two different species. Twelve to thirteen of the casts are ribs as well as long bones of the leg including: a femur, tibiae, and fibulae. Also archosaur like tarsals and possibly D. tuetonis neural spines. No footprints were on the slab but two possible diadectid burrows openings are preserved on the surface.

\section{Comparison of postcranial bone histology of carnivorous and herbivorous pelycosaur groups [oral presentation]}

\section{Christen D. Shelton ${ }^{1} \&$ P. Martin Sander ${ }^{1}$ \\ ${ }^{1}$ Rheinische Friedrich-Wilhelms University, Steinmann Institute of Mineralogy, Geology and Palaeontology, Bonn, Germany; E-mails: cshelton@uni-bonn.de\& martin.sander@uni-bonn.de}

We examined bone histology of carnivorous pelycosaurs (Varanopidae, Ophiacodontidae, and Sphenacodontidae) and compared it to histology of herbivorous pelycosaurs (Caseidae, and Edaphosauridae). Long bones were sectioned at the mid-diaphysis. There is a difference in the histology between the postcranial elements themselves; however there is a strong correlation within these two groups, specifically the vascularization pattern in the cortex as well as the periosteal bone tissue. Carnivorous pelycosaurs have a vascularization pattern that consists of radial rows of longitudinal canals with varying degrees of anastomosis and lamellar infilling specific to each group. Similar patterns are seen in the postcrania of sauropterygians. Also, woven bone is exclusive to the carnivores. One exception is that Edaphosaurus has a similar vascularization pattern to that of the carnivores, more so in the humeri than in the femora, but the size of the longitudinal canals are small like those seen in varanopids. Large herbivore species (Lupeosaurus and Cotylorbynchus) have a random vascular pattern or none at all. Large caseids are mostly osteoporotic and avascular. 


\title{
Sedimentological characteristics and foraminifera fauna of the Upper Mississippian cyclothems in the Lower Yangtze Block [oral presentation]
}

\author{
Sheng Qingyi ${ }^{1}$ \\ ${ }^{1}$ Chinese Academy of Sciences, Nanjing Institute of Geology and Palaeontology, Nanjing, P. R. of Cbina; \\ E-mail:sheng.qingyi@163.com
}

In the Lower Yangtze Block, there are typical transgressive-regressive depositional sequences present in Upper Mississippian shallow marine successions. They are composed of subtidal to intertidal carbonates with frequently and cyclically intervening subaerial siliciclastic/clay rocks and/or exposure surfaces. Based on detailed field measurements, polished slab and thin section studies, and analysis of sedimentary structures, 12 major microfacies, and 5 transgressive-regressive cycles are recognized.

Foraminifers are the primary contributor to establishing a chronostratigraphical framework of the shallow cyclothems. The foraminiferal assemblage, including Eostallella hobsienica, Asteroarchaediscus rugosus, Asteroarchaediscus baschkiricus, Loeblichia sp., Asteroarchaediscus postrugosus, Eostaffellina paraprotvae, Endothyranopsis crassa and so on, suggest the cyclothems having a range from the late Visean to Late Serpukhovian in age.

The five cycles are comparable to those in other areas in South China and even in Euramerica, likely due to the frequent glacio-eustasy that began during the latest Visean.

\section{Evolutionary pattern of Permo-Carboniferous fusulinid fauna in South China [oral presentation]}

Shi Yukun ${ }^{1}$

'Nanjing University, School of Earth Sciences and Engineering, Nanjing, P. R. of China;
E-mail:ylesbi@nju.edu.cn

Finding out the evolutionary pattern of biological faunas in geological history is one of the most important and exciting parts of paleontological research. Based on detailed paleontological work on fusulinid specimens from the Moscovian to Early Kungurian strata in the Zongdi Section, Guizhou Province, South China, statistical analyses are carried out to testify the early results on the Permo-Carboniferous fusulinid evolutionary pattern in South China.

As the results of systematic study, 429 species belonging to 35 genera have been identified from 2,676 specimens. To validate the change of the fusulinid genus and species diversities in the Zongdi Section, several biodiversity indices and a statistical test by the rarefaction analysis have been applied to uncover the evolutionary pattern. The present results showed consistence with conclusions of early researches on fusulinid diversity pattern in South China, indicating a species 
climax in the Sphaeroschwagerina subrotunda zone of the Sakmarian, Early Permian, and two turnover events during the Kasimovian to Gzhelian, and Late Sakmarian to Artinskian.

\title{
I Like Palaeontology - Facebook marketing as a platform for com- municating with society members, students and interested guests [poster presentation]
}

\author{
Alexandra Solarczyk ${ }^{1} \&$ Alexander Mudroch $^{1}$ \\ ${ }^{1}$ NaTourWissen Ltd., Hannover, Germany; E-mail: asolarczyk@natoumissen.de
}

Facebook is a virtual platform that is used everywhere on every continent. But it is not just a way to keep in touch with friends or a possibility to meet new ones. For companies and organizations like the Palaeontological Society, it holds the potential to come to an uncomplicated exchange of information with its members and interested guests. Dates, announcements, changes, and so on can easily be posted on the Facebook page and spread quickly. By commenting those messages you have a quick feedback in return. Members become aware of important topics and the opinions of other followers and can step right into a discussion about it. A society and its members, especially student members, come closer together. It offers non-members an easy access to palaeontological information and a platform to come into contact with real experts and other members. With every new visitor on the Facebook page, the organization is a little bit more known by interested persons. And if they Like or Recommend posts on the page, every other visitor or follower will be notified about that. But only continuous work can guarantee a lively contact to members and guests. An assigned editor that is responsible for all the posts and changes on the page is important for the success of social marketing for Palaeontology via Facebook.

\section{An upgraded perspective on basal Sphenacodontia, the stem group of mammal-like amniotes [poster presentation]}

\author{
Frederik Spindler ${ }^{1}$, Kirstin Brink $^{2} \&$ Graciela Piñeiro ${ }^{3}$ \\ ${ }^{1}$ Technical University Bergakademie Freiberg, Institute of Geology, Department of Palaeontology, Freiberg/Sa., \\ Germany; E-mail:mail@frederik-spindler.de \\ ${ }^{2}$ University of Toronto, Department of Biology, Mississanga, Ontario, Canada; \\ E-mail:kirstin.brink@mail.utoronto.ca \\ ${ }^{3}$ Facultad de Ciencias, Departamento de Evolución de Cuencas, Montevideo, Uruguay; E-mail: fossil@fcien.edu.uy
}

Pelycosaur-grade Sphenacodonts appeared first in the Desmonesian. The Missourian Garnett fauna indicates a richer diversity than known so far, with four to six haptodont-grade taxa. Mainly differing by dentition, this assemblage is a model of 
dietary niche diversification, a kind of "Carboniferous Darwin's finches". Moreover, all basal sphenacodonts vary most in jaws and teeth, but are almost constant postcranially. A revised phylogeny of sphenacodontids uses tooth morphology to distinguish between species of Dimetrodon, and suggests that several species are likely invalid. The enigmatic Tetraceratops is doubted to be the basalmost therapsid. A diastema is also present in undescribed haptodonts, making this no longer a sphenacodontoid feature. When basal synapsids disappeared, only varanopids survived to the higher Permian, restricted to Gondwana, where older "pelycosaurs" are totally unknown so far. Recently discovered remains from the Late Permian of South America, soon to be described, might reveal advanced sphenacodontid-like forms, supporting a Gondwanan radiation of non-therapsid synapsids at the beginning of the therapsid dominance.

\section{Devonian successions at the northern margin of the Maider (S-Morocco): microfacies, palaeoecology and stratigraphy [posterpresentation]}

Sören Stichling ${ }^{1}$, R. Thomas Becker ${ }^{1}$, Sarah Z. Aboussalam ${ }^{1}$, Stephan Helling ${ }^{1}$, Marie-Kristin Rytina ${ }^{1}$ \& Dustin Ward ${ }^{1}$

${ }^{1}$ Westfälische Wilhelms-Universität Münster, Institut für Geologie und Paläontologie, Münster, Germany;

E-mail:s_stic01@uni-muenster.de

Devonian outcrops in the Anti-Atlas of Morocco, especially of the Tafilalt and Maider areas, are well known and have been the subject of intensive palaeoecological and stratigraphical research. Givetian biostromes are located in the South and North of the Maider region and have also been studied in the Ouihlane syncline at the northern margin. We focused on two neglected outcrops, which represent at present the northernmost reefal structures of the Anti-Atlas (stable Gondwana). The Boultan South section contains limestone-marl alternations that range from Lower to Upper Emsian. These deposits are characterized by pelagic sediments only with rugose deep water corals and rare, heavily fragmented, branching Tabulata. The Lower/Upper Emsian boundary is marked by the Daleje Event formed by green shales. The Tarherat location contains upper Eifelian limestones with goniatites and shales overlain by Givetian sediments, which mostly consist of coral- and crinoid-bearing debris-flows. The growth of small biostromal complexes changed from the upper Eifelian into the formation of massive coral and stromatoporid biostromes. 


\title{
Plant fossils from the Neogene in the Ninghai region of Zhejiang Province, China and palaeoclimatic implications [oral presentation]
}

\author{
Sun Bainian ${ }^{1}$, Xiao Liang $^{2}$, Li Xiangchuan², Li Ruiyun ${ }^{1}$, Ma Fujun ${ }^{1}$, Wang \\ Qiujun $^{1} \& \mathbf{X u}$ Xiaohui $^{1}$ \\ 'Lanzhou University, School of Earth Sciences, Lan₹hou, P. R. of China; E-mail: bnsun@lru.edu.cn \\ ${ }^{2}$ Chang'an University, College of Earth Science and Resources, Xi'an, P. R. of China
}

The studies of Neogene climatic changes are very important for the prediction of the future climate trends. Plant fossils are good records of past climatic changes, and may provide us with valuable evidence to understand the climatic and environmental changes through the geologic time.

Zhejiang Province, located in southeast China, is in the middle-low latitudes of the Northern Hemisphere, where a mid-subtropical monsoon climate prevails. Eastern Zhejiang is one of the best areas for preserved Cenozoic plant fossils in China. The continental strata in the basinal-hilly areas of eastern Zhejiang are lithologically called the Shengxian Formation. Recently, many fossils with good cuticles were collected from the Shengxian Formation in the Ninghai region of eastern Zhejiang, China. The Shengxian Formation is comprised of several beds of basalt with fluvial-lacustrine interlayers, and it is confined to the Miocene based on the geological constraints of the basaltic dates and regional correlations.

More than 800 specimens of plant fossils were collected from the continental strata. Of them, some fossils are fruits, seeds. The flora shows a subtropical evergreen broad-leaved forest with some temperate trees. For example, the genera Cinnamomum, Litsea, Machilus, Castanopsis, Lithocarpus, Caesalpinia and Mallotus are generally distributed in the tropic or subtropic regions, but the genera Betula, Acer, Carpinus, Amelanchier, Cercidiphyllum and Cornus are the key elements in the northern hemisphere temperate forests. The hydrophyte Trapa lived in the lake; the evergreen broad-leaved forests and some single species forests of Cunninghamia and Pinus premassoniana are distributed in an area of 300-600 $\mathrm{m}$ a.s.l. Some shrub trees grow under the evergreen arbors, and the vines of Smilax climb on the arbors or shrubs. Palaeoclimatic characteristics of the Miocene flora were of a higher temperature than that of today.

This work was conducted under the National Basic Research Program of China (973 Program) (No. 2012CB822003), the National Natural Science Foundation of China (No. 41172022), and Specialized Research Fund for the Doctoral Program of Higher Education (No. 20120211110022).

\section{A new Bennettitalean leaves and evidence of plant-insect interaction from the Middle Jurassic, China [oralpresentation]}

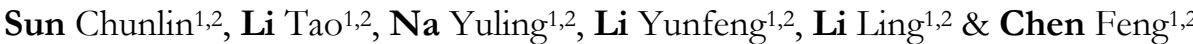


${ }^{1}$ Ministry of Education, Key Laboratory for the Evolution of Past Life and Environment in Northeast Asia, Changchun, P. R. of China; E-mail: clsun@jlu.edu.cn

${ }^{2}$ Jilin University, Research Center of Paleontology and Stratigraphy, Changchun, P. R. of China

Many research results have indicated that the interactions between arthropods, especially insects and plants are very common in modern terrestrial ecosystems. However the data on the interactions from the fossils is relatively scarce and scattered. Recently abundant fossil plants were collected from the Middle Jurassic in the contiguous areas of Inner Mongolia and western Liaoning, China. Some specimens assigned to the genus Anomozamites (Bennettitaleans) show valuable evidence of hairs, trichomes and insect predation on the leaves. The densely acerate hairs directed or bent towards the leaf apex are distributed on both sides of the petiole and the rachis. The villus or subulate hairs occur on the abaxial side of the leaflets. At the meantime, the feeding traces produced by mandibulate phytophagous insects are preserved in most of the leaflets. The existence of feeding traces demonstrate that some phytophagous insects lived on Anomozamites leaves. The specimens of simultaneously existing hairs, trichomes and excisions on the Bennettitalean leaves are very rare in the Mesozoic flora worldwide. The present specimens provide valuable material for the study of insect-plant interaction and coevolution.

\title{
The Late Triassic and Middle Jurassic floras from the Junggar Basin of Xinjiang, NW China [oral presentation]
}

\author{
Sun Ge ${ }^{1,2}$, Miao Yuyan ${ }^{3} \&$ Volker Mosbrugger ${ }^{4}$ \\ 1Shenyang Normal University, College of Paleontology, Shenyang, P. R. of China; E-mail: sunge@synu.edu.cn \\ ${ }^{2}$ Ministry of Education, Key Laboratory for the Evolution of Past Life and Environment in Northeast Asia, \\ Changcbun, P. R. of China \\ ${ }^{3}$ Beijing Museum of Natural History, Beïing, P. R. of China; E-mail: myyzzh@126.com \\ 4 Senckenberg Research Institute and Natural History Museum, Frankfurt/M., Germany; \\ E-mail:Volker.mosbrugger@senckenberg.de
}

The Late Triassic and Middle Jurassic floras are abundant in the non-marine deposits of the Junggar Basin of Xinjiang, Northwest China. The Late Triassic flora is characterized by the Danaeopsis-Nanzhangophyllum assemblage (Ass. I, CarnianNorian, in the Huangshanjie Formation) and the Glossophyllum-Cycadocarpidium assemblage (Ass. II, Norian-Rhaetian, in the Haojiagou Formation). The early Middle Jurassic flora is represented by the flora from the Xishanyao Formation, featured by the Coniopteris-Raphaelia assemblage (Ass. IV) and forming large industrial coal-beds distributed in huge areas in Xinjiang, including the Junggar-, Tarim-, and Turpan-Hami basins. Paleoclimatically, it appears to change from a warm and moist to a warm-temperate and humid climate, with gradually increasing seasonal changes from the Late Triassic to early Middle Jurassic, in general, which 
is documented by the abundance of deciduous plants such as Ginkgoales and Czekanowskiales enriched in the coal-bearing beds of the Xishanyao Formation. The moderate warm and moist climates were more favorable for the large forests contributing to the coal formation. The huge industrial coal mines (e.g. the Sharhu Coal Mine in Turpan-Hami basin) exploited in recent years are nearly the same age as the Xishanyao Formation's.

\title{
A general review of Sino-German cooperative study on Mesozoic ecosystems and strata in Xinjiang, China, during 1997-2012
} [keynote presentation]

\author{
Sun $\mathrm{Ge}^{1,2}$, Volker Mosbrugger ${ }^{3}$, Sun Chunlin ${ }^{2,4}$, Thomas Martin ${ }^{5}$ \& A. Rahman \\ Ashraf $^{6}$ \\ 1Shenyang Normal University, College of Paleontology, Shenyang, P. R. of China; E-mail: sunge@synu.edu.cn \\ ${ }^{2}$ Ministry of Education, Key Laboratory for the Evolution of Past Life and Environment in Northeast Asia, \\ Changchun, P. R. of Cbina \\ 3 Senckenberg Research Institute and Natural History Museum, Frankfurt/M., Germany; \\ E-mail:Volker.mosbrugger@senckenberg.de \\ ${ }^{4}$ ilin University, Research Center of Paleontology and Stratigraphy, Changchun, P. R. of China; \\ E-mail: clsun@jlu.edu.cn \\ ${ }^{5}$ Rheinische Friedrich-Wilhelms University, Steinmann Institute of Mineralogy, Geology and Palaeontology, Bonn, \\ Germany; E-mail:tmartin@uni-bonn.de \\ ${ }^{6}$ Eberhard-Karls University of Tübingen, Department of Geosciences, Tübingen, Germany; \\ E-mail:rahman.ashraf@uni-tuebingen.de
}

Fruitful achievements have been gained by the Sino-German cooperative study on Mesozoic ecosystems and strata in Xinjiang, NW China, during the past 15 years (1997-2012). The main results comprise (1) Paleobotany \& Palynology: including the first discovery of a Late Triassic flora from Haojiagou nearby Urumqi in the Junggar Basin (Sun et al. 2001, 2010); establishing high resolution palynostratigraphic sequences (T3-J2) in the Haojiagou section (Ashraf et al. 2001, 2010); and further study of the early Middle Jurassic Baiyanhe flora (Sun et al. 2010); (2) Vertebrate Paleontology: including the discoveries of the most diverse Late Jurassic mammal assemblage of Asia in the Qigu Formation of the southern Junggar Basin (Martin et al. 2004, 2010); the largest dinosaur tracksite from the Middle Jurassic Sanjianfang Formation in Shanshan of the Turpan-Harmi Basin (Wings et al. 2007); a mass accumulation of exceptionally well preserved xinjiangchelyid turtles (Rabi et al. 2012), and giant sauropod dinosaurs in the late Middle Jurassic Qigu Formation associated with theropod teeth and bivalves, etc. in Shanshan (Wu et al. 2013); (3) Paleoclimatology: including the discoveries of paleoclimatic signals from cyclic growth pattern in dinosaur bones (Pfretzschner et al. 2001), and others in the Junggar Basin (Martin et al. 2010). Furthermore, the Sino-German cooperative activities have been extended by establishment of the "Sino-German Co-Working Station for Geosciences in Xinjiang" (SGWSGX) in Urumqi (2000- ), and the 
"Sino-German Joint Lab on Paleontology \& Geosciences" in Changchun (20052009). Five Sino-German cooperative symposia were successfully organized in China (2001, 2004, 2007, 2008) and in Germany (2006).

\title{
Deep divergence dating of Branchiopoda based on relaxed molecular clock analyses with multiple fossil calibrations [oral presentation]
}

\author{
Sun Xiaoyan ${ }^{1}$, Xia Xuhua ${ }^{2} \&$ Yang Qun ${ }^{1}$ \\ ${ }^{1}$ Chinese Academy of Sciences, Nanjing Institute of Geology and Palaeontology, State Key Laboratory of Palaeobiology \\ and Stratigraphy, Nanjing, P. R. of China; E-mail:qunyang@nigpas.ac.cn \\ ${ }^{2}$ University of Ottawa, Department of Biology, Ottawa, Ontario, Canada
}

Branchiopoda is a group of predominantly freshwater crustaceans with a fossil record dating back at least 500 million years, probably representing an earliest component of the terrestrial fauna on the Earth. In order to establish the evolutionary timescale for the origin and early divergences of branchiopods, we here construct a dated phylogeny of major branchiopod lineages using a molecular supermatrix comprising 62 single-copy nuclear protein-coding genes for 36 arthropod species in the constraint of available fossil dates of early arthropods. We selected thirteen external and one internal fossil calibration points, which were evaluated for emipirical scaling factor via cross-validation analyses within the framework of a multi-gene phylogeny. Divergence dates were calculated using Bayesian relaxed molecular clock and penalized likelihood methods. Our results show that the stem group of Branchiopoda is rooted in the Late Neoproterozoic $(563 \pm 7 \mathrm{Ma})$; the crown-groups diverged during early Ordovician to middle Cambrian (478-512 Ma), likely indicating the origin of the modern freshwater biota. The Phyllopoda clade diverged during the Ordovician (448-480 Ma) and Diplostraca during the late Ordovician to early Silurian (430-457 Ma). We further evaluated the congruence between the time estimates from the fossil record and those from different molecular clock models, revealing that the uncorrelated rate model gives more congruent results for shallower divergence events while the autocorrelated rate model gives more congruent results for deeper events.

\section{Aptian floras in eastern and central Jilin, China and the atmospheric p $\mathrm{CO}_{2}$ [oral presentation]}

\author{
Sun Yuewu ${ }^{1,2}$, Zhao Guowei ${ }^{3}$, Wan Chuanbiao ${ }^{4} \&$ Gao Yan $^{5}$ \\ ${ }^{1}$ Ministry of Education, Key Laboratory for the Evolution of Past Life and Environment in Northeast Asia, \\ Changchun, P. R. of China; E-mail: sunyuewu@jlu.edu.cn \\ ${ }^{2}$ Jilin University, Research Center of Paleontology and Stratigraphy, Changchun, P. R. of China \\ 3 Jilin University, College of Earth Science, Changchun, P. R. of China \\ ${ }^{4}$ Daqing Oiffield Limited Company, Exploration and Development Research Institute, Daqing, P. R. of China
}


We present estimated $\mathrm{CO}_{2}$ concentrations during the Aptian based on stomatal indices from well-preserved specimens of Ginkgo from the Changcai Formation, eastern Jilin, and the Yingcheng Formation, central Jilin, Northeast China. The ages of the two formations were well calibrated using LA-ICP-MS U-Pb isotopic dating of zircons from andesite and rhyolite beds within the formations. The results show that the estimated atmospheric $\mathrm{CO}_{2}$ concentration from the Changcai Formation is 658.87-685.42 ppmv (Recent Standardization, RS). This represents the atmospheric $p \mathrm{CO}_{2}$ during the time between the early Aptian Selli (OAE 1a) and the middle Aptian Fallot OAEs, 2 times more than the present level. Our estimation of the atmospheric $p \mathrm{CO}_{2}$ for the latest Aptian - earliest Albian (OAE $1 \mathrm{~b}$ ) is from the Yincheng Formation, which is 681.70-685.42 ppmv (RS), slightly higher than that from the Changcai Formation. This might indicate that there was not any great emission of $\mathrm{CO}_{2}$ in the latest Aptian.

This work is financially supported by the National Natural Science Foundation of China (Grant Nos. 30670138, 31270277).

\section{Virtual Palaeontology: Past, Present and Future [keynote presentation]}

\section{Mark Sutton ${ }^{1}$}

'Imperial College, Department of Earth Science \& Engineering, London, U.K.; E-mail: m.sutton@ic.ac.uk

Virtual Palaeontology, here defined as the study of three-dimensional fossils through digital visualisations, is rapidly becoming one of the most important approaches to the study of palaeontological material. These methodologies can be the only practical means of studying certain fossils, and also bring benefits of convenience, ease of dissemination, and amenability to dissection and mark-up. They are in a sense not new - a long pre-history of physical-optical tomography throughout the $20^{\text {th }}$ century predates the true origin of virtual palaeontology in the 1980s - but uptake has increased markedly in the last ten years. This boom has been driven primarily by advances in X-ray computed tomography and computational resources, but a wide range of other technologies are also now available. Techniques fundamentally divide into (a) surface-based and (b) tomographic approaches. Surface-based techniques include laser-scanning and photogrammetry, and provide rapid and effective digitisation of external surfaces. Tomographic techniques, based around the generation of serial 'slice' images, are more diverse and complex, but provide the potential for resolution of internal structures. They sub-divide primarily into destructive and non-destructive methods; the former includes traditional serial grinding (here termed 'physical-optical tomography'), as well as focused ion beam (FIB) tomography. Non-destructive methods include a range of scanning technologies (CT and synchrotron CT, MRI, neutron tomography) as well as serial-focusing methods ('optical tomography'). Methods for 
reconstruction and visualisation of virtual fossil data are also diverse, and are treated briefly. Finally, challenges for and future developments in the field of virtual palaeontology are discussed; challenges include the fostering of a culture of data-exchange for virtual specimens, which among other things requires the establishment of standardised file-formats.

\title{
The Silurian Herefordshire Lagerstätte [invited oral presentation]
}

\author{
Mark Sutton ${ }^{1}$, Derek Siveter ${ }^{2,3}$, David Siveter ${ }^{4}$ \& Derek E. G. Briggs ${ }^{5,6}$ \\ 'Imperial College, Department of Earth Science \& Engineering, London, U.K.; E-mail:m.sutton@ic.ac.uk \\ ${ }^{2}$ University Museum of Natural History, Geological Collections, Oxford, U.K. \\ ${ }^{3}$ University of Oxford, Department of Earth Sciences, Oxford, U.K.; E-mail:derek.siveter@earth.ex.ac.uk. \\ ${ }^{4}$ University of Leicester, Department of Geology, Leicester, U.K.; E-mail: djs@leicester.ac.uk. \\ ${ }^{5}$ Yale University, Department of Geology \& Geophysics, New Haven, Connecticut, U.S.A. \\ ${ }^{6}$ Yale Peabody Museum of Natural History, New Haven, Connecticut, U.S.A.; E-mail: derek.briggs@yale.edu
}

The Herefordshire Lagerstätte is a mid-Silurian deposit preserving a range of marine invertebrates complete with soft-tissues. The fossils are preserved as threedimensional calcite void-fills in carbonate nodules. They are impossible to extract or image in their entirety without the use of tomographic techniques; the deposit hence provides a testbed and showcase for the 'virtual palaeontology' approach. Over 14 years of study, it is has generated a wealth of often new and unexpected palaeobiological data on a range of groups, including molluscs, echinoderms, brachiopods, polychaetes, and most especially arthropods. Animals preserved are primarily epibenthic, but infaunal and nekto-benthic forms are also represented. Recent finds discussed in detail here include a chiton-like mollusc and a potential stem-group euarthropod, but additional spectacular animals continue to emerge.

\section{A new technique to decipher the epidermal structure of Yanliaoa [posterpresentation]}

\author{
Tan Xiao ${ }^{1,2}$, Zhang $\mathrm{Yi}^{1,2,3}$ \& Sun $\mathrm{Ge}^{1,2,3}$ \\ 1Shenyang Normal University, College of Paleontology, Shenyang, P. R. of China; E-mail: tanxiao1115@163.com \\ 2Paleontological Museum of Liaoning, Shenyang, P. R. of China \\ ${ }^{3}$ Ministry of Land \& Resources, Key Laboratory for Paleontological Evolution in Northeast Asia, Shenyang, P. R. of \\ China
}

A new technique for deciphering the epidermal structure of Yanliaoa collected from the Middle Jurassic of western Liaoning, China, is introduced. The technique is stepped in process by removing contamination on surfaces of fossil leaves with chemical treatment first, then using the cellulose peel technique in the specimens; after that, the light microscope with a large depth-of-field, and the SEM are 
applied. The result clearly shows that the epidermal structure of Yanliaoa appears to be similar to that of Sequoia in stomatal bands and stomatal apparatus. The new method overcomes shortcomings of the traditional cellulose peel technique, and provides a new referred approach for analyzing and studying the epidermal structure of fossil leafy shoots.

\title{
New data of fossil Osmundaceous ferns (Filicales) from the Middle Jurassic of western Liaoning, NE China and their evolutionary significance [oral presentation]
}

\author{
Tian Ning ${ }^{1,2,3}$, Wang Yongdong ${ }^{4}$, Zhang Wu ${ }^{5} \&$ Jiang Zikun ${ }^{6}$ \\ 1Shenyang Normal University, College of Paleontology, Shenyang, P. R. of China; E-mail: tianning84@163.com \\ ${ }^{2}$ Chinese Academy of Sciences, Nanjing Institute of Geology and Palaeontology, State Key Laboratory of Palaeobiology \\ and Stratigraphy, Nanjing, P. R. of China \\ ${ }^{3}$ Ministry of Land \& Resources, Key Laboratory for Paleontological Evolution in Northeast Asia, Shenyang, P. R. of \\ China \\ ${ }^{4}$ Chinese Academy of Sciences, Nanjing Institute of Geology and Palaeontology, Nanjing, P. R. of China \\ 5 Shenyang Institute of Geology and Mineral Resources, Shenyang, P. R. of China \\ ${ }^{6}$ Chinese Academy of Geological Sciences, Institute of Geology, Beijing, P. R. of China
}

Two new structurally preserved osmundaceous rhizomatous species, Ashicaulis beipiaoensis sp. nov. and $A$. wangii sp. nov. are documented from the Middle Jurassic Tiaojishan Formation in Beipiao, Liaoning Province, northeastern China. The species $A$. beipiaoensis, with a homogeneous parenchymatous pith, is characterized by a homogeneous sclerotic ring, a crescent-shaped sclerenchyma mass in the vascular bundle concavity and a large homogeneous sclerenchyma mass accompanied by several smaller thick-walled fiber clusters in the petiolar stipular wings. Another new species, $A$. wangii, with a heterogeneous pith, is featured by a heterogeneous petiolar sclerotic ring, a crescent-shaped sclerenchyma mass in the petiolar cortex, numerous sclerenchyma clusters in the petiolar inner cortex and one large homogeneous sclerenchyma mass occurring in the stipular wings. Comparisons of anatomical features suggest that $A$. beipiaoensis bears close similarities to Osmunda shimokawaensis Matsumoto \& Nishida from the Middle Miocene of Hokkaido, Japan. The two species may represent an extinct branch in the Osmundaceae evolutionary tree. Whereas $A$. wangii shows similarities to Osmunda pluma Miller from the Paleocene of Dakota, USA. On the other hand, among all the 28 reported Ashicaulis species worldwide, four species are with a heterogeneous petiolar sclerotic ring, and three of them are described from the Middle Jurassic in western Liaoning, China. A. wangii represents another new taxon of Ashicaulis with the heterogeneous petiolar sclerotic ring. Extant osmundaceous plants are commonly with heterogeneous petiolar sclerotic ring, those osmundaceous rhizome remains with such a structure from China contribute to further understanding the origin of the living Osmundaceae. On the petiolar sclerenchyma arrangement, 
A. wangii shows similarities to Osmunda pluma Miller from the Paleocene of Dakota, USA. In conclusion, the current report of these two new species contributes to the structural knowledge and species diversity of fossil osmundaceous ferns in China and provides further information for understanding the Mesozoic evolution and geological occurrences of the osmundaceous ferns in the Northern Hemisphere.

Jointly supported by the State Key Programme of Basic Research of Ministry of Science and Technology, China (2012CB822003), National Natural Sciences Foundation of China (NSFC 41272010 and 40972008), Team Program of Scientific Innovation and Interdisciplinary Cooperation, CAS, Science Research Project of Liaoning Provincial Education Department (L2012391) and Doctoral Fund of Shenyang Normal University.

\section{The Permian-Triassic Boundary Sequences in South China: Impli- cation to the Great Transitional Events [oral presentation]}

Tong Jinnan ${ }^{1}$

${ }^{1}$ China University of Geosciences, State Key Laboratory of Biogeology and Environmental Geology, Wuban, P. R. of China; E-mail:jntong@cug.edu.cn

South China was situated in the low-latitude eastern Tethyan archipelago during the Permian-Triassic time, and thus it has well-developed continuous marine Permian-Triassic transitional sequences with rich fossil records. Since the Global Stratotype Section and Point (GSSP) of the Permian-Triassic boundary was defined at Meishan in South China in 2001, the GSSP of the Changhsingian Stage, the highest Palaeozoic stage, has been clarified at the same locality, and the top boundary of the Induan Stage, the lowest Mesozoic stage, also has a potential GSSP candidate in South China. Consequently, South China would be the first choice to study the great Palaeozoic-Mesozoic transitional events.

On the other hand, South China had a distinctive differentiation of sedimentary palaeogeography and lithofacies through the Permian-Triassic transition. The Permian-Triassic boundary sequences vary strongly from littoral, even paralic terrigenous clastic facies or shallow carbonate buildup facies, to deep basin cherty or fine clastic facies, even turbidity facies, although the normal shallow shelf or platform facies dominated South China during the time. As the stratigraphic sequences were formed in various sedimentary settings, they had recorded different environmental information and various environmental events would have produced different sedimentary records in the rocks. The investigation and explanation from some boundary sequences in specific palaeogeography and lithofacies might result in some lopsided deductions in the understanding of the great transitional events.

We collect and review all the Permian-Triassic boundary sequences so far reported in South China. Most sections were discovered and examined during the geological survey, but many of the important sequences have been further studied for the Permian-Triassic stratigraphic boundary and related transitional events. 
Especially for the survey of the candidates of the GSSP of the Permian-Triassic boundary, many important boundary sequences had been extensively studied in stratigraphy, and thus once the GSSP was defined at Meishan, the boundary could be properly traced and correlated according to the index fossils and the related events such as the "boundary clay bed", carbon isotope anomaly, and others.

\section{The fauna of Lindabrunn $(380 \mathrm{~m}$, Lower Austria) and its indications for the climate and environmental changes at the end of the Pleistocene [posterpresentation]}

Kristof Veitschegger ${ }^{1} \&$ Doris Nagel ${ }^{1}$

\section{${ }^{1}$ University of Vienna, Department of Palaeontology, Vienna, Austria; E-mails: kristof.veitschegger@gmx.net \& doris.nagel@univie.ac.at}

The archaeological site Pecher cave (Lower Austria) yielded, besides artefacts, a wide range of different animal species. The lowermost layer of Pomatias elegans marks the bottom of the profile. This is a small landsnail adapted to warmer conditions. Therefore it can be assumed that the sediments of the excavation reach till the Bolling-Interstadial. A dated lower jaw of Lepus timidus also supports this. The jaw is 14,230-13,880 cal. BP (VERA-5723) in age and this represents probably the last occurrence of the mountain hare in the Vienna basin. It retreated then to the high altitude of the Alps. The middle section is characterized by species adapted to colder conditions, which are today only found in Northern Europe, the Alps and parts of Asia. Among them are Rangifer tarandus, Lepus timidus, Chionomys nivalis, Dicrostonyx sp. and Marmota marmota. Capreolus capreolus, Cervus elapbus, and Lepus europaeus appear in the profile primarily in the superposed layers and indicate a warming phase. Besides specimens of more than 35 different mammalian taxa, the excavation also yielded Neolithic stone tools and medieval pottery. Furthermore, a small fragment of the atlas from a human was found and dated to an age of 6,2706,050 cal. BP (VERA-5724).

\section{The continental Triassic Madygen Lagerstätte (southwest Kyrgyzstan, Central Asia) [oralpresentation]}

Sebastian Voigt ${ }^{1}$, Ilja Kogan ${ }^{2}$, Michael Buchwitz ${ }^{3}$, Jan Fischer ${ }^{1}$, Philippe Moisan $^{4}$, Jörg W. Schneider ${ }^{2}$, Frederik Spindler ${ }^{2}$, Andreas Brosig ${ }^{2}$, Marvin Preusse $^{2} \&$ Frank Scholze ${ }^{2}$

${ }^{1}$ Geoskop Urweltmuseum/Burg Lichtenberg (Pfalz), Thallichtenberg, Germany;

E-mail: s.voigt@pfalzmuseum.bv-pfali.de

${ }^{2}$ Technische Universität Bergakademie Freiberg, Geologisches Institut, Freiberg/Sa., Germany

${ }^{3}$ Museum für Naturkunde, Magdeburg, Germany

${ }^{4}$ Westfälische Wilhelms-Universität Münster, Institut für Geologie und Paläontologie, Münster, Germany 
The Madygen Formation is a $560 \mathrm{~m}$ thick Middle Triassic succession of alluvial, fluvial, and lacustrine deposits outcropping near the village of Madygen in SW Kyrgyzstan, Central Asia. As one of the world's richest Triassic fossil localities, the Madygen Formation has an outstanding role in the reconstruction of the evolution of Mesozoic terrestrial ecosystems. The Madygen Formation has yielded one of the most diverse Mesozoic floras of Eurasia, various aquatic invertebrates, more than 20,000 insects of almost all contemporaneous groups, freshwater sharks, actinopterygians, lungfishes, coelacanths, amphibians, chroniosuchians, therapsids, and diapsids. Its status as a lagerstätte is based on the exceptional preservation of both aquatic and terrestrial biota, including soft-tissue preservation in tetrapods. The Kyrgyz study area offers a unique taphonomic window into the life and environmental conditions of an intra-cratonic basin of mid-northern palaeolatitude that certainly deserves further attention by multidisciplinary research.

\title{
Late Palaeozoic Diadectidae (Cotylosauria: Diadectomorpha) and their potential preference for inland habitats [posterpresentation]
}

\author{
Sebastian Voigt ${ }^{1}$, Spencer G. Lucas ${ }^{2} \&$ Jan Fischer ${ }^{1}$ \\ ${ }^{1}$ Geoskop Urweltmuseum/Burg Lichtenberg (Pfali), Thallichtenberg, Germany; \\ E-mails:s.voigt@pfalzmuseum.bv-pfali.de_j.fischer1@yahoo.de \\ 2New Mexico Museum of Natural History, Albuquerque, New Mexico, U.S.A.; E-mail: spencer.lucas@state.nm.us
}

Diadectidae is a diverse group of terrestrially-adapted reptiliomorphs known from Late Pennsylvanian-Early Permian (Kasimovian-Kungurian) strata of equatorial Pangaea. Given their supposed plant diet, possible reproduction on land, and large abundance of fossils in intracontinental red-beds, it has been proposed that diadectids preferentially inhabited inland to upland environments. To test this hypothesis, we studied the distribution of diadectid body- and ichnofossils from New Mexico, USA, because its Pennsylvanian-Permian strata range in a depositional setting from tropical tidal flats in the south to alluvial aprons around highland areas in the north. With one exception, all New Mexican diadectid fossils come from alluvio-fluvial red-beds that accumulated at least $120 \mathrm{~km}$ landward from the nearest marine shoreline. Considering the relative abundance of diadectid remains in central and northern parts of the state, our data strongly suggest that diadectids preferred inland habitats and avoided coastal lowlands.

\section{Breaking with traditional concepts - a new classification for the order Sirenia (Mammalia) [oral presentation]}

\author{
Manja Voss ${ }^{1}$ \\ ${ }^{1}$ Museum für Naturkunde, Leibniz Institute for Research on Evolution and Biodiversity, Berlin, Germany; \\ E-mail:manja.voss@mfn-berlin.de
}


The monophyly of Sirenia is well supported by morphological and molecular data, but the phylogeny and systematics of this group are still challenged in many parts. Sea cows are conventionally divided into four families: the "Prorastomidae" and "Protosirenidae" that are extinct and restricted to the Eocene, and the "Dugongidae" and Trichechidae that have extant representatives. There have been made very few changes to the traditional classification concept, which considers mainly paraphyletic groups. The paraphyly specifically refers to the extinct dugongid subfamily "Halitheriinae", the revision of which resulted in the new and hitherto most comprehensive phylogeny of Sirenia presented here. As a consequence, the taxonomic concept for the whole order is revised and expanded, promoting amongst others a consequent differentiation between a paraphyletic stem group and a monophyletic crown group. The crown group is further subdivided, which is also partially supported by biogeographic data. However, no taxonomic consequence is performed for the stem group, either due to paraphyly and/or in order to avoid a non-practical accumulation of nominal taxa.

\title{
Holocene palaeoclimate reconstruction in the Eastern Mediterra- nean: a quantitative diatom study of an approximately $18 \mathrm{~m}$ long sediment core from Lake Kinneret (Israel) [poster presentation]
}

\author{
Hannah $\operatorname{Vossel}^{1} \&$ Thomas Litt $^{1}$ \\ ${ }^{1}$ Rheinische Friedrich-Wilhelms University, Steinmann Institute of Geology, Mineralogy and Palaeontology, Bonn, \\ Germany; E-mails:bvossel@uni-bonn.de \& t.litt@uni-bonn.de
}

This study comprises preliminary investigations of an $18 \mathrm{~m}$ core documenting remarkable shifts in the diatom flora of Lake Kinneret over the last ca. 8000 years. $98 \%$ of the diatom taxa can be classified as oligohalobous-indifferent, requiring alkaline water for optimal growth. Five main diatom assemblage zones can be recognised based on changes in the composition of the diatom assemblages and distinctive changes in the diatom concentration. Changes in the diatom assemblages over the last ca. 8000 years can be interpreted mainly in terms of productivity shifts, from an oligotrophic flora at the base to hypereutrophic in the modern lake. The trend towards eutrophication accelerates after 3000 years cal. BP, indicating the influence of increased human activity in the catchment.

There is also some evidence for lake-level fluctuations. Low lake-level stands are characterised by a low diatom concentration and the increasing occurrence of littoral taxa. High lake level stands are marked by the occurrence of planktonic species, such as Cyclotella ocellata, in huge numbers and high diatom concentrations. 


\title{
Subseasonal to inter-annual seawater temperature variability during the Rupelian (Early Oligocene) of the Mainz Basin, Germany [posterpresentation]
}

\author{
Eric O. Walliser ${ }^{1}$, Bernd R. Schöne ${ }^{1}$, Jessica Zirkel $^{2} \&$ Thomas Tütken $^{3}$ \\ 1 Johannes-Gutenberg University, Institute of Geosciences, Main₹,Germany; E-mail: walliser@uni-mainz.de \\ 2Johann-W olfgang-Goethe University, Institute of Geosciences, Frankfurt/M., Germany \\ ${ }^{3}$ Rheinische Friedrich-Wilhelms University, Steinmann Institute of Geology, Mineralogy and Palaeontology, Bonn, \\ Germany
}

The Oligocene world $\left(\not C \mathrm{C}_{2}>1800 \mathrm{ppm}\right.$, unipolar glaciation) represents a possible scenario for future climate. As such, it provides a natural laboratory for studying the effects of global warming. In this contest, fossil bivalve shells function as archives of past seawater temperature (ST) required to verify and constrain numerical climate models.

Here, we discuss the $\delta^{18} \mathrm{O}_{\text {shell }}$ data of a Glycymeris sp. specimen from the Rupelian marine deposits of the Alzey-Formation (Mainz Basin, Germany) to reconstruct the subseasonal to inter-annual ST-variability. The $\delta^{18} \mathrm{O}$ signature of the water $\left(\delta^{18} \mathrm{O}_{\mathrm{w}}=1.1 \% \mathrm{SMOW}\right)$ during that time was estimated from phosphate $\delta^{18} \mathrm{O}$ of coeval dugong teeth.

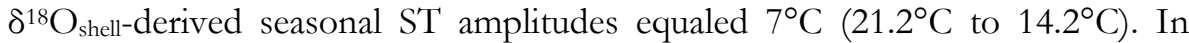
contrast, annual average temperatures varied between $15.7^{\circ} \mathrm{C}$ and $18.5^{\circ} \mathrm{C}$. These results are in agreement with previous studies of Early Oligocene ST variability, but show $\sim 2^{\circ} \mathrm{C}$ greater seasonal variations. Our study demonstrates the importance of highly resolved archives such as bivalve shells to gain a better insight into the Oligocene climate of northern Europe, the test bed for future climate scenarios.

\section{Lagerstätten of buoy crinoids (Scyphocrinitidae, Echinodermata) thriving in Upper Silurian gyres of narrowing oceans between Africa, America and China [oral presentation]}

\author{
Otto H. Walliser ${ }^{1}(\dagger)$, Maria G. Corriga ${ }^{2}$, Carlo Corradini ${ }^{2} \&$ Reimund Haude $^{1,3}$ \\ ${ }^{1}$ Georg-August University Göttingen, Geoscience Centre, Department of Geobiology, Göttingen, Germany; \\ E-mail: rbaude@gwdg.de \\ ${ }^{2}$ Università di Cagliari, Dipartimento di Scienze Chimiche e Geologiche, Cagliari, Italy; \\ E-mails:maria.corriga@unica.it@ corradin@unica.it \\ ${ }^{3}$ Georg-August University, Geoscience Museum and Geopark, Göttingen, Germany
}

Crinoid skeletons disarticulate postmortally rather rapidly. Hence, well preserved fossil crowns indicate local exceptional sedimentary conditions, e.g. obrution or sudden environmental poisoning. However, world-wide Lagerstätten of Upper Silurian-Lower Devonian scyphocrinoids suggest another biostratinomic process: 
burial of the large flower-like crowns and long stems below skeletal masses of many conspecific individuals. In the Silurian, when widely extended successions of black shales mirror highly restricted environmental conditions at greater depth, the benthic forerunner of the scyphocrinoids transformed its strongly branching original anchoring device into a unique rootlet-walled gas container, the bladdershaped "lobolith". By means of this functional buoy, these crinoids floated in the surface waters, thus profiting from plankton-rich trophic environments. Wellknown stratigraphic and palaeogeographic occurrences of scyphocrinoid taxa suggest not only rapid distribution, but also an obvious provincialism by possibly extended gyre-like current regimes of Sargasso sea-type.

\section{Nanshanopteris nervosus gen. et sp. nov., a supaioid foliage from the Late Permian Sunan Formation in Yumen, western China [oral presentation]

\author{
Wan Mingli1 ${ }^{1,2} \&$ Wang Jun ${ }^{2}$ \\ ${ }^{1}$ University of Chinese Academy of Sciences, Beijing, P. R. of China; E-mail:mlwan@nigpas.ac.cn \\ ${ }^{2}$ Chinese Academy of Sciences, Nanjing Institute of Geology and Palaeontology, State Key Laboratory of Palaeobiology \\ and Stratigraphy, Nanjing, P. R. of China
}

A new form of once-pinnate supaioid foliage, Nanshanopteris nervosus gen. et sp. nov. is found from the Late Permian Sunan Formation in Dashankou, Gansu, western China. Pinnules are auricular, semicircular and tongue-shaped. The apical and basal pinnules gradually decrease in size relative to those in the middle part of the frond. The venation is open dichotomous and very dense. Veins are derived from the rachis at the base of the lower leaf margin. Pinnules are amphistomatic. On both the lower and upper epidermis, epidermal cells are polygonal, and stomata are present parallel to the subtle veins. Papillae occur on the subsidiary cells and overarch the stomatal pores. Hardly any papillae occur on normal cells of the upper epidermis. Frond morphology and cuticular features suggest that the plant is probably a new member of Peltaspermales. It might be an endemic species in the Cathaysian-Angaran mixed flora of western China. Judging from the characteristics of the new plant, such as the significant thickness of the cuticles, the strong papillosity and deeply sunken stomata, together with other associated xeromorphic plants like conifers, as well as in consideration of the lithostratigraphy of the section, the new plant probably grew along a lake margin or streamside in a seasonally wet climate. 


\title{
Early Cretaceous insect faunas from China [oral presentation]
}

\author{
Wang $\mathrm{Bo}^{1} \&$ Zhang Haichun ${ }^{1}$ \\ ${ }^{1}$ Chinese Academy of Sciences, Nanjing Institute of Geology and Palaeontology, State Key Laboratory of Palaeobiology \\ and Stratigraphy, Nanjing, P. R. of China; E-mail: savantwang@gmail.com
}

Abundant insects were described from the Lower Cretaceous of China during the past 30 years, but few studies are focused on their geological settings, especially the definite geological ages. Herein we reviewed these Early Cretaceous insect-bearing localities, and presented the updated geological ages of these fossil layers based on isotopic dating results and stratigraphic investigations. The most famous fossil insect assemblage in China is the Jehol insect fauna, occurring in 3 horizons: the Dabeigou Formation (ca. 135-130 Ma; late Valanginian-Hauterivian), Yixian Formation (ca. 130-122 Ma; Barremian-early Aptian), and Jiufotang Formation (ca. 122-?120 Ma; middle Aptian). These insects are mainly recorded from southern Inner Mongolia Autonomous Region, northern Hebei and Liaoning provinces.

The Jiuquan Basin in Gansu Province of northwestern China also yields abundant Early Cretaceous insects. The deposits are divided into three formations: (1) Chijinpu (Chijinbao) Formation (early Aptian); (2) Xiagou Formation (late Aptian or late Aptian-early Albian); (3) Zhonggou Formation (Albian). Earlier insect collection was mainly from the Chijinpu Formation, represented by abundant Ephemeropsis trisetalis Eichwald. Very recently, plenty of fossil insects from the Zhonggou Formation have been collected, including caddisfly cases, adults of dragonfly (probably Hemeroscopus baissicus Pritykina), and Coptoclava larvae. The Laiyang Formation in eastern Shandong Province preserves plenty of Mesolygaeus laiyangensis Ping and Coptoclava longipoda Ping, and its geological age equals that of Jiufotang Formation (middle Aptian). The Lushangfen Formation in western Beijing City is the late Aptian-early Albian in geological age. The Dalazi Formation (Albian) in eastern Jilin Province yields many angiosperm fossils and abundant Coptoclava sp., which is bigger than the typical Coptoclava longipoda. Only two Early Cretaceous formations in South China yield plenty of insects. The Shouchang Formation in western Zhejiang Province yields abundant Coptoclavidae, and its age is probably the same as that of the Yixian Formation. Another is the Shixi Formation in a new locality in eastern Jiangxi Province. Its geological age remains unclear, and is probably slightly younger than that of the Yixian Formation.

Impressions and carbonaceous compressions occur in all fossil insect deposits included in this study. Pyritized insect fossils were observed for the first time within lacustrine deposits with volcanogenic sediments (Dabeigou and Yixian Formations). These insect faunas, almost spanning the entire Early Cretaceous (from Valanginian to Albian), provide important windows to understanding the macroevolutionary history of insects and to explore the co-evolutionary process between insects and flowering plants. 


\title{
Geomicrobiology in a dark oligotrophic karst cave in central China [oral presentation]
}

\author{
Wang Hongmei ${ }^{1}$, Yun Yuan ${ }^{1}$, Zhou Jianping ${ }^{1}$, Xiang Xing ${ }^{1} \&$ Dong Qiang $^{1}$ \\ ${ }^{1}$ China University of Geosciences, State Key Laboratory of Geobiology and Environmental Geology, Wuban, P. R. of \\ China; E-mail:hmwang@cug.edu.cn
}

Heshang cave is a dark, alkaline and oligotrophic karst cave in the middle reach of Yangtze River. How the dark ecosystem functions in the Heshang Cave and what kind of microbes are involved in the geochemical processes are fascinating fundamental issues to decipher. We investigate the microbial communities in dripping waters via culture-dependent and culture-independent methods. Seasonal variation was observed in microbial communities, associated with the seasonal changes of atmospheric temperature and local precipitation. Isolates of Pseudomonas, the predominate genus in microbial communities, is demonstrated to be capable to dissolve poorly soluble zinc phosphate via decreasing the environmental $\mathrm{pH}$. The phosphorus released is much higher in content than that required for the growth of the isolates, and thus can further support the growth of other microbes in the ecosystem. Our data underline the seasonal variation of microbial communities and their function in sustaining the dark ecosystem. It greatly enhances our insight into the ecological picture of cave systems.

\section{Community reproductive ecology of the 300 mys vegetational Pompeii: detecting the phenology of the Wuda Tuff Flora, Inner Mongolia [oral presentation]}

\author{
Wang Jun ${ }^{1} \&$ Feng Zhuo ${ }^{2}$ \\ ${ }^{1}$ Chinese Academy of Sciences, Nanjing Institute of Geology and Palaeontology, State Key Laboratory of Palaeobiology \\ and Stratigraphy, Nanjing, P. R. of Cbina; E-mail:jun.wang@nigpas.ac.cn \\ ${ }^{2}$ Yunnan University, Yunnan Key Laboratory for Palaeobiology, Kunming, P. R. of China
}

The Wuda Tuff Flora, as a peat forming vegetation from the earliest Permian of Inner Mongolia buried in volcanic ash, has been called a Chinese vegetational Pompeii, with respect to its preservation, in a way much like the Roman city of Pompeii. Based on the actual location of individual plants, a reconstruction of $1,137 \mathrm{~m}^{2}$ of the forest has been carried out, which is large enough for an investigation of the floral ecology. Six major plant groups consist of the flora, including Lycopsids, Sphenopsids, Noeggerathialeans, ferns, primitive cycadophytes and coniferophytes. Due to the $\mathrm{T}^{0}$ preservation, this flora provides an excellent insight into the spatial structure, but also significantly into the flora community ecology. A preliminary investigation of ontogeny of the individual taxa of the forest suggests that phenology had appeared in this 300 mys vegetation. 
Marattialean tree ferns are most abundant, represented by a number of species of Pecopteris. Among them, Pecopteris arborescens and P. cf. candolleana have their fertile frond well developed, whereas the other species including Pecopteris orientalis, $P$. anderssonii, $P$. densifolia and $P$. lativenosa are only represented by their sterile fronds. Herbaceous ferns include Nemejcopteris feminaeformis, Cladophlebis, and Sphenopteris. Only Sphenopteris bears Oligocarpia-type sporangia. A fertile frond was not present in Nemejcopteris and Cladophlebis. Lycopsids are represented by Sigillaria cf. ichthyolepis, the tall pole-like trees, mostly bearing strobili of various dimensions. Two sphenopsids were encountered, Sphenophyllum, a dwarf shrub, and a small CalamitesAsterophyllites, developed only in small patches. They all bear strobili of consistent size. Noeggerathiales, an extinct spore-bearing group of uncertain systematic position, are represented by species of Tingia and Paratingia. Their strobili were frequently seen, with marked heterospory. Gymnosperms include possible early representatives of the cycads, Taeniopteris and Pterophyllum, and Cordaites trees that were early coniferophytes with a generally modern growth habit, except for the large strap-shaped leaves with parallel venation. The seeds of Taeniopteris are 1.5$2 \mathrm{~cm}$ in dimension, indicating a maturity. The cones of Cordaites are rarely found, and are very small in consideration of their large dimension as a tall tree, indicating that they are certainly immature. The reproductive organ of Pterophyllum has not yet been found in the present flora. In addition, a newly found sphenopterid foilage with seeds attached, indicates the occurrence of pteridosperms. They might not be recognized because their seeds had mostly not yet been produced in that season.

\title{
Insect under cover: a new phasmatodean from the Early Cretaceous Jehol biota [oralpresentation]
}

\author{
Wang Maomin ${ }^{1}$, Olivier Béthoux ${ }^{2}$, Sven Bradler ${ }^{3}$, Frédéric M. B. Jacques ${ }^{4}$, Cui \\ Yingying $^{1,5} \&$ Ren Dong ${ }^{1}$ \\ ${ }^{1}$ Capital Normal University, Key Laboratory of Insect Evolution and Environmental Changes, Beijing, P. R. of \\ China; E-mails:wangmaomin1987@yaboo.cn; cuiying19860105@gmail.com@o rendong@mail.cnu.edu.cn \\ 2Muséum National d'Histoire Naturelle, UMR 7207 CNRS (CR2P), Paris, France; E-mail: obethoux@mnbn.fr \\ ${ }^{3}$ Georg-August University, Johann-Friedrich-Blumenbach Institute of Zoology and Anthropology, Göttingen, \\ Germany; E-mail: sbradle@gwdg.de \\ ${ }^{4}$ Chinese Academy of Sciences, Xishuangbanna Tropical Botanical Garden, Key Laboratory of Tropical Forest \\ Ecology, Mengla, P. R. of China; E-mail: menisperm@gmail.com \\ ${ }^{5}$ Technical University Bergakademie Freiberg, Institute of Geology, Department of Palaeontology, Freiberg/Sa., \\ Germany
}

Fossil species that can be conclusively identified as stem-relatives of stick- and leafinsects (Phasmatodea) are extremely rare, especially for the Mesozoic era. This dearth in the paleontological record makes assessments on the origin and age of the group problematic and impedes investigations of evolutionary key aspects, such as wing development, sexual size dimorphism and plant mimicry. A new 
fossil insect species is described on the basis of one female and two male specimens recovered from the Yixian Formation (Early Cretaceous, ca. $126 \pm 4$ mys; Inner Mongolia, NE China; known as 'Jehol biota'). The occurrence of a female abdominal operculum and of a characteristic 'shoulder pad' in the forewing allows for the interpretation of a true stem-Phasmatodea. In contrast to the situation in extant forms, sexual size dimorphism is only weakly female-biased in this species. The peculiar wing coloration, viz. longitudinal veins darkly colored, suggests that a Ginkgophyte-like plant was used as model for crypsis. These data suggest that, as early as in the Early Cretaceous, some stem-Phasmatodea achieved effective plant mimicry, although additional refinements characteristic of recent forms, such as curved fore femora, were still lacking. The diversification of small-sized arboreal insectivore birds and mammals might have triggered the development of such primary defenses.

\title{
Progress on the study of the GSSP at the base of the Serpukhovian Stage [oral presentation]
}

\author{
Wang Qiulai ${ }^{1}$, Sheng Qingyi ${ }^{1}$, Paul Brenckle ${ }^{2}$, Qi Yuping ${ }^{1} \&$ Hu Keyi ${ }^{1}$ \\ ${ }^{1}$ Chinese Academy of Sciences, Nanjing Institute of Geology and Palaeontology, Nanjing, P. R. of China; \\ E-mail:wangqiulai521@gmail.com \\ ${ }^{2}$ Westport, Massacbusetts, U.S.A.
}

The evolutionary appearance of the conodont species Lochriea ziegleri within the lineage Lochriea nodosa-L. riegleri is being discussed as the most promising marker for the Visean/Serpukhovian (V/S) boundary. Two leading candidates for the Serpukhovian GSSP, the Verkhnyaya Kardailovka section (South Urals) and the Naqing section (South China), along with other potential candidate sections are under intensive investigation (Richards \& Task Group, 2013). The FAD of Locbriea ziegleri and its lineage are still not clear in the South Urals because of the relatively shallow-water setting and low conodont abundance, although the V/S boundary at the Kardailovka section can be indirectly correlated with the help of foraminifers (Kulagina et al. 2011) and ammonoids (Nikolaeva 2013). A new study (Sevastopulo \& Barham in press) indicates that ammonoids around the base of the Serpukhovian are strongly provincial in their distribution. For example, Uralian ammonoid species are totally different, and genera largely different, from those in northwestern Europe. Therefore, using ammonoids for international correlation at this stratigraphic level is not practical. The deep-water Naqing section exhibits a welldeveloped Lochriea succession across the V/S boundary but lacks other diagnostic fossils to correlate to age-equivalent shallow-water sections that are generally conodont-poor. This correlation problem may be partly resolved with the recent discovery of Serpukhovian foraminifers from the newly studied Dianzishang section in Guizhou Province, South China, where foraminifers belonging to 
Eolasiodiscus donbassicus, Globivalvulina sp., Howchinia subconica and Semiendothyra sp. have been identified around the FAD of L. ziegleri.

\title{
A discussion of "Mastodon grandincisivus" based on new findings from the Late Miocene of the Linxia Basin, China [oral presentation]
}

\author{
Wang Shiqi ${ }^{1}$, He Wen ${ }^{2}$, Chen Shanqin ${ }^{2} \&$ Dong Liping ${ }^{1}$ \\ ${ }^{1}$ Chinese Academy of Sciences, Institute of Vertebrate Paleontology and Paleoanthropology, Key Laboratory of \\ Vertebrate Evolution and Human Origins, Beijing, P. R. of China; E-mail: wangshiqi@ivpp.ac.cn \\ 2Hezheng Paleozoological Museum, Hezheng, P. R. of China; E-mail: hzbwg_5524668@126.com
}

The systematic position of Mastodon (Bunolophodon) grandincisivus Schlesinger, 1917 has been debated for nearly 100 years. It was previously considered either a Stegotetrabelodon or an Amebelodon. Recently, we discovered many proboscidean remains from the Late Miocene of the Linxia Basin, China, which may help resolve this problem. The mandible belonging to these remains has an elongated symphysis with flattened lower tusks and maxillary intermediate teeth that are tetralophodont as in "M. grandincisivus". However, dentinal tubules could not be observed in the cross-section of the lower tusks as would be typical of M. grandincisivus. The cranium has a somewhat raised neurocranium and erected basicranium, indicating characters that are derived in comparison with those of other known amebelodontines. The upper tusks are bent downwards, with enamel covers being distinct from those in the straight-tusked taxon "M. grandincisivus". The limb bones are thicker than in extant elephants. A preliminary cladistic analysis shows that the new specimens and "M. grandincisivus" comprise a monophyletic group that is inserted between the Gomphotheriinae and tetralophodont gomphotheres, and the monophyletic group does not cluster with either the Amebelodontinae or the Stegotetrabelodontinae. Thus this group may represent a distinct evolutionary clade. A new genus should be created to include the new taxon and "M. grandincisivus", possibly as well as Amebelodon cyrenaicus.

\section{Integrated isotopic studies of the Ediacaran successions in shallow and deep water facies of South China [oral presentation]}

\author{
Wang Wei ${ }^{1}$, Zhou Chuanming ${ }^{1}$, Guan Chengguo ${ }^{1}$, Yuan Xunlai ${ }^{1} \&$ Chen $^{2}{ }^{1}$ \\ ${ }^{1}$ Chinese Academy of Sciences, Nanjing Institute of Geology and Palaeontology, State Key Laboratory of Palaeobiology \\ and Stratigraphy, Nanjing, P. R. of China; E-mail:wangweigal@gmail.com
}

Carbon isotope compositions in marine carbonate rocks have long been used for paleoceanographic reconstruction. The combined datasets from the Ediacaran Doushantuo Formation in South China show that both $\delta^{13} \mathrm{C}_{\text {carb }}$ values and their variations in four sedimentary faces are significantly different, and pronounced 
$\delta^{13} \mathrm{C}_{\text {carb }}$ shifts occur much more often in shallow-water than in deep-water sections, which are here interpreted as being closely related to the stepwise evolution of the Ediacaran Doushantuo ocean of South China. The evolutionary history of the Ediacaran Doushantuo ocean could be divided into three stages according to the $\delta^{13} \mathrm{C}_{\text {carb }}$ data: the first stage corresponds to the duration of cap dolostone deposition, during which the Yangtze block is probably an open-platform, carbonate ${ }^{13} \mathrm{C}_{\text {carb }}$ values are possibly inherited from the mental-sourced $\mathrm{CO}_{2}$ gas and do not show significant difference between shallow- and deep-water environments of the Doushantuo ocean. The second stage encompasses the member II and lower member III of the Doushantuo Formation, during which $\delta^{13} \mathrm{C}_{\text {carb }}$ values from basinal facies are significantly lower than those from platform facies. Unlike the great increase in platform facies, $\delta^{13} \mathrm{C}_{\text {carb }}$ values for deep-water carbonates do not show any significant difference compared with the previous stage. The third stage occurs in the upper member III and member IV of the Doushantuo Formation. All $\delta^{13} \mathrm{C}_{\text {carb }}$ values from different sedimentary facies decrease compared with those in the second stage, resulting in the relatively low discrepancy of $\delta^{13} \mathrm{C}_{\text {carb }}$ values between shallow- and deep-water environments. The stepwise carbon isotope evolution of the Ediacaran Doushantuo ocean after the cap dolostone deposition is probably attributed to the progressive remineralization of a large dissolved organic carbon (DOC) reservoir via bacterial sulfate reduction.

For the $\delta^{13} \mathrm{C}_{\text {carb }}$ trend in shallow water facies, a pronounced negative $\delta^{13} \mathrm{C}_{\text {carb }}$ shift that can be potentially correlated with the Shuram excursion has been reported from the middle Ediacaran strata through the Yangtze Gorges area of South China. Here we carried out a detailed $\delta^{13} \mathrm{C}_{\text {carb }}$ analysis of the Lianghong section in the western part of Yangtze platform. The Ediacaran System at Lianghong is overlain by the Maidiping Formation yielding early Cambrian small shelly fossils and underlain by the Cryogenian Lieguliu Formation diamictite and tuffaceous siltstones. It comprises the Guanyinya and Hongchunping Formations, which have been traditionally correlated with the Doushantuo and Dengying Formations in the Yangtze Gorges area, respectively. Two negative $\delta^{13} \mathrm{C}_{\text {carb }}$ excursions occur in the Lianghong section. The lower one at the uppermost Guanyinya Formation, with a nadir at $-8.6 \%$, may be correlated with the pronounced negative $\delta^{13} \mathrm{C}_{\text {carb }}$ shift (EN3) in the uppermost Doushantuo Formation in the Yangtze Gorges area and possibly to the well known Shuram event in Oman. The upper negative $\delta^{13} \mathrm{C}_{\text {carb }}$ excursion occurs in the upper Hongchunping Formation and may be correlated with negative excursions (EN4) near the Ediacaran/Cambrian boundary. Other negative $\delta^{13} \mathrm{C}_{\text {carb }}$ excursions (e.g., EN1 and EN2) are not expressed in the Lianghong section because the lower Guanyinya Formation is dominated by siliciclastic rocks. Combined with previously published Ediacaran $\delta^{13} \mathrm{C}_{\text {carb }}$ profiles, our results indicate that the EN3 excursion (likely a Shuram equivalent) may occur widely in South China and can be a useful chemostratigraphic feature for regional and global stratigraphic correlation. It may represent a perturbation to the ocean carbon cycle rather than a record of post-depositional alteration. This will help 
clarify if $\delta^{13} \mathrm{C}_{\text {carb }}$ variations can be used for chemostratigraphic correlation of Ediacaran successions.

For the $\delta^{13} \mathrm{C}_{\text {carb }}$ trend in deep water facies, we carried out high resolution carbon (both inorganic and organic), oxygen, and strontium isotopic analyses on the Ediacaran succession at the Shiyu section, South China. The results show that a pronounced negative $\delta^{13} C_{\text {carb }}$ shift (EN3 or Shuram event) with a nadir at $-19.2 \%$ (VPDB) occurs in the middle Ediacaran Lantian Formation, shortly after which the $\delta^{18} \mathrm{O}$ profile demonstrates a sharp negative shift from $\sim-10 \%$ to $\sim-25 \%$ o (VPDB). These negative shifts are accompanied by elevated ${ }^{87} \mathrm{Sr} /{ }^{86} \mathrm{Sr}$ ratios ranging from 0.708715 to 0.714690 . The extremely negative $\delta^{18} \mathrm{O}$ values $(-20.2 \%$ to $-26.7 \%$, VPDB) are interpreted as reflecting deglacial meltwater input, which is consistent with the associated high initial ${ }^{87} \mathrm{Sr} /{ }^{86} \mathrm{Sr}$ ratios $(0.711801$ to 0.714690$)$. The onset of the middle Ediacaran glaciation may result in more severe ocean ventilation, while deglaciation may deliver more oxidants into the ocean. Both trigger remineralization of a deep ocean DOC reservoir, thus leading to the pronounced negative $\delta^{13} \mathrm{C}_{\text {carb }}$ shift in the middle Ediacaran. This carbon isotope event has been interpreted as resulting from the remineralization of a large dissolved organic carbon (DOC) reservoir trapped in the deep ocean, riverine input of oxidized fossil organic matter, or release of methane from the ocean.

\section{Environmental and cultural dynamics since latest Pleistocene in Southeast China [oral presentation]}

Wang Weiming ${ }^{-1} \&$ Shu Junwu ${ }^{1}$

${ }^{1}$ Chinese Academy of Sciences, Nanjing Institute of Geology and Palaeontology, Nanjing, P. R. of China;

E-mail:wmwang@nigpas.ac.cn

Southeast China is one of the most important areas in revealing the development process of early rice farming and its relationship with the natural environment. Extensive studies including natural vegetation sequences, surface pollen samples and Neolithic sites in the lower reaches of the Yangtze River have already well demonstrated the relationship between environmental changes and human activates (Shu et al. 2007; Wang et al. 2010a, 2010b). Additionally, well-dated archaeological sedimentary microfossil records at Kuahuqiao in Hangzhou, proposed an environmental context for the first rice cultivation at about $7750 \mathrm{cal}$. BP (Zong et al. 2007; Innes et al. 2009; Shu et al. 2010). It exhibits that local woods dominated by oak (Quercus) and pine (Pinus) were targeted for burning before the start of rice agriculture (Shu et al. 2012).

The initiation of agriculture is suggested to come with the establishment of more or less sedentary residences in the study area. Warming climate after the last glaciations is considered as a major factor that allowed the distribution of the wild rice northward. Food requirement and storage are another factor in initiating early rice farming, while the increasing population and climatic variation might greatly 
promote its development (Wang et al. 2010a). The global climate of the last 21,000 years exhibits dramatic changes and abrupt events, which engendered a great control to the formation and afterward development of local agriculture. To explore the detailed interaction between the natural background and prehistorical agriculture, a series of long drill cores form some representative sites in Southeast China are under comprehensive study for further evidence.

This project is supported by the CAS Strategic Priority Research Program (Grant No. XDA05120101) and the Pilot Project of Knowledge Innovation, CAS (KZCX2-YW-155).

\title{
Updating the Carboniferous GSSPs research in South China [oral presentation]
}

\author{
Wang Xiangdong ${ }^{1} \&$ Qi Yuping ${ }^{1}$ \\ ${ }^{1}$ Chinese Academy of Sciences, Nanjing Institute of Geology and Palaeontology, Nanjing, P. R. of China; \\ E-mail: xdwang@nigpas.ac.cn
}

Global tectonics combined with Gondwanan glaciation confounds the subdivision of the Carboniferous and also complicates global correlations. Four Carboniferous stages, including the Serpukhovian of the Mississippian, the Moscovian, the Kasimovian and the Gzhelian of the Pennsylvanian, still do not have Global Stratotype Sections and Points (GSSPs). Thus, four Task Groups were established ten years ago to search for their candidate GSSPs worldwide.

Marine Carboniferous sediments are well developed and widely distributed in South China. Especially sections with continous carbonate-dominated successions are well exposed in Guizhou Province of South China, such as the Naqing section, the Narao section, the Luokun section, the Dianzishang section, the Fengting section, the Zongdi section and the Yashui section, among which the most representative section is the Naqing section in Luosu, Luodian of Guizhou. It is a candidate section for the GSSPs of the global Serpukhovian, Moscovian, Kasimovian and the Gzhelian stages.

Continuous centimeter-scale sampling of the relatively deep water sections mentioned above in recent years has provided new data for a more detailed biostratigraphy of conodonts across the Visean/Serpukhovian, Bashkirian/Moscovian, Moscovian/Kasimovian and the Kasimovian/Gzhelian boundaries (Wang \& Qi 2003, 2007; Qi \& Wang 2005; Qi et al. 2007, 2009, 2010a, 2010b, 2010c, 2011, 2012, 2013; Wang et al. 2008, 2011; Barrick et al. 2010). The key mark conodont species of above boundaries, such as Lochriea ziegleri, Diplognathodus ellesmerensis, Idiognathodus turbatus and Idiognathodus simulator, are found, and their evolutionary lineages are also studied or under intense investigation in South China. Other fossil groups, including foraminifers and corals, as well as chemostratigraphy and sedimentology of the above boundary intervals in South China are also being studied (Wu et al. 2009; Ueno et al. 2010; Buggisch et al. 2011; Lin et al. 2012; Groves et al. 2012; Ma et al. 2013). 


\title{
Schmeissneria: A Jurassic angiosperm or a member of Ginkgoales? [oral presentation]
}

Wang Xin ${ }^{1}$

${ }^{1}$ Chinese Academy of Sciences, Nanjing Institute of Geology and Palaeontology, Nanjing, P. R. of China;

E-mail: brandonbuijunwang@gmail.com

Schmeissneria was initially established as a new genus in Ginkgoales in 1994. It was then demonstrated not to be connected to ginkgoalean leaves of Baiera, unlike assumed by Schenk, who related Schmeissneria-like organs to Baiera (Ginkgoales) based on association alone. Wang et al. (2007) cast doubt on the position of Schmeissneria in Ginkgoales, and related it to angiosperms for the first time. This proposal was not well accepted. Therefore, information in German specimens of Schmeissneria becomes a focus of all questions. Reinvestigation of the syntype and new material of Schmeissneria in Germany confirms that the conclusion based on Chinese material is correct. The German material includes female inflorescences and infructescences in various statuses and connected with shoots and leaves. Light microscopy and scanning electron microscope observations of Chinese and German materials together indicate that the fruits of Schmeissneria have in situ seeds enclosed, and that the ovaries are closed before pollination. The confirmation of these features in Schmeissneria indicates that angiospermy plus angio-ovuly are present in this Jurassic plant, pinning down the position of Schmeissneria in angiosperms. As a Middle Jurassic angiosperm, Schmeissneria extends the evidenced history of angiosperms at least back to the Early Jurassic. This conclusion helps to narrow the gap between molecular datings and the fossil record of angiosperms, and demands a revision of the history of angiosperms.

\section{Floral and ecological changes across the Triassic-Jurassic transition in the Sichuan Basin, SW China [oralpresentation]}

Wang Yongdong ${ }^{1}$, Tian Ning $^{2}$, Jiang Zikun ${ }^{3}$, Xie Xiaoping ${ }^{4}$, Huang Qisheng, Li Liqin ${ }^{1}$

\author{
${ }^{1}$ Chinese Academy of Sciences, Nanjing Institute of Geology and Palaeontology, Nanjing, P. R. of Cbina; \\ E-mail:ydwang@nigpas.ac.cn \\ 2Shenyang Normal University, College of Paleontology, Shenyang, P. R. of China \\ ${ }^{3}$ Chinese Academy of Geological Sciences, Institute of Geology, Beijing, P. R. of China \\ ${ }^{4}$ Qufu Normal University, College of Geography and Tourism, Riz̧hao, P. R. of China \\ ${ }^{5}$ China University of Geosciences, Wuban, P. R. of China
}

The extensive distribution and development of the Early Mesozoic strata make the Sichuan Basin one of the best known areas for the Triassic-Jurassic studies in China. In particular, the Triassic and Jurassic sequences are continuously cropped out in this basin yielding diverse fossil biota. The Upper Triassic and the Jurassic 
strata represent the non-marine fluvial and lacustrine deposits bearing a variety of fossil plants and fauna. The Upper Triassic deposits are well developed in northern, Southern and NW borders of the Sichuan Basin, and is represented by the Xujiahe Formation. Abundant and diverse fossil biotas have been documented in this formation, including plants, spore-pollen, bivalves, conchostracans and ostrocodes, indicating Norian to Rhaetian age. The Lower Jurassic sequences Zhenzhuchong and Ziliujing Formations consist of shell limestones, purple red mudstone and limestones with sandstone or variegated bed. The former formation is the basal part of the sequence ( corresponding to the Hettangian), and it conformably overlies the Upper Triassic Xujiahe Formation; the Ziliujing Formation may roughly correspond to the Sinemurian-Toracian. The Triassic/Jurassic boundary is defined in between the Upper Jurassic Xujiahe Formation and the base of the Lower Jurassic Zhenzhuchong Formation.

The fossil plants from the Xujiahe Formation are considered as a typical South "Dictyophyllum-Clathropteris" Flora. The composition of this flora is mainly dominated by cycads, and Bennettitales are particularly diverse; Ferns are the second group in diversity. Sphenophytes shows high occurrence frequency. The Upper Triassic Flora in eastern Sichuan Basin include four plant communities, such as coastal hydrophyte community, marsh humid hygrophyte community, bank \& plain hygrophyte to Mesophyte shrub, arboresent forest community, and the mesophyte and xerophyte uplant arboresent forest community. The Early Jurassic floras of the Sichuan Basin are mainly documented from the Zhenzhuchong Formation. The floral composition of the Zhenzhuchong Flora is distinct from the Xujiahe Flora. This flora is featured by the dominance of ferns and cycads, the rise of the Dicksoniaceae, the decrease of pteridophytes and the occurrence of ginkgophytes and conifers. It is noteworthy that some arid and hot elements (Brachyphyllum and Pagiophyllum) have been described from this flora showing important climate significances.

The climate in the Zhenzhuchong Period shows close succession relationship with the Late Triassic Xujiahe Period in northeastern Sichuan regions. The humid climate continued from the Late Triassic to the late Early Jurassic in Kaixian; the humid climate last to the early Early Jurassic in the lacustrine and delta regions in Xuanhan and Daxian regions. In conclusion, the Early Jurassic climate show on difference from that of the Late Triassic, prevailed by hot and humid conditions, and the temperature increase while the humidity decrease compared with than that of Late Triassic.

Jointly supported by the State Key Programme of Basic Research of Ministry of Science and Technology, China (2012CB822003); the National Natural Sciences Foundation of China (NSFC 41272010, 40972008) and the Team Program of Scientific Innovation and Interdisciplinary Cooperation, CAS. 


\title{
Diverse neuropterans in the Mesozoic ecosystems of northeastern China [poster presentation]
}

\author{
Wang Yongjie ${ }^{1} \&$ Ren Dong ${ }^{1}$ \\ ${ }^{1}$ Capital Normal University, College of Life Science, Beijing, P. R. of China; E-mails: wangyjosmy@yahoo.cn \& \\ rendong@mail.cnu.edu.cn
}

Mesozoic Neuroptera shows the most species richness and morphological diversity in northeastern China, suggesting it should have been a golden time for neuropterans in Mesozoic Era. Up to date, 18 families, 42 genera and 56 species have been described in Mesozoic China, and mainly found in the Jiulongshan Formation and Yixian Formation. Based on morphological data, incorporating most fossil and extant families, the familial phylogenetic relationships of Neuroptera were reconstructed. Combining the fossil records of Neuroptera, the familial division time of Neuroptera was discussed. Four extinct families, Permithonidae, Archeosmylidae, Mesithonidae and Nevrorthidae constitute the stem-groups of Neuroptera, representing the earliest division of Neuroptera. The suborder Myrmeleontiformia is confirmed, and Saucrosmylidae, Kalligrammatidae, Panfiloviidae, Aetheogrammatidae and Grammolingidae are assigned to the suborder. The superfamily Chrysopoidea is corroborated, comprising Limaiidae, Tachinyphidae, Allopteridae, Mesochrysopidae and Chrysopidae. According to the fossil records of Neuroptera, it is inferred that the familial division of Neuroptera likely occurred in the Middle Jurassic. The Mesozoic fossil lacewings exhibit some specialized co-evolution relationships with the contemporaneous plants and environments that have been lost in the modern insects, etc. The oldest pinnate leaf-mimicking insects, Bellinympha filicifolia and B. dancei, reveal a specialized co-evolution of insects and gymnosperms. Other extinct groups, Kalligrammatidae, Grammolingidae and Saucrosmylinae, show some special traits that are different from the modern neuropterans, e.g. extremely large body size, peculiar wing marks and special behavioral adaptation. These enigmatic insects implied the diverse living strategies of Neuroptera before the adaptation of angiosperms. The research of Mesozoic neuropterans would promote our knowledge to understand the early evolutionary history of Neuroptera.

\section{Quantifying the process and abruptness of the end-Permian mass extinction [oral presentation]}

Wang Yue ${ }^{1}$, Peter M. Sadler ${ }^{2}$, Shen Shuzhong ${ }^{1}$, Douglas H. Erwin ${ }^{3}$, Zhang Yichun $^{1}$, Wang Xiangdong ${ }^{1}$, Wang Wei ${ }^{1}$, James L. Crowley ${ }^{4}$ \& Charles M. Henderson $^{5}$

${ }^{1}$ Chinese Academy of Sciences, Nanjing Institute of Geology and Palaeontology, State Key Laboratory of Palaeobiology and Stratigraphy, Nanjing, P. R. of China; E-mail:yuewang@nigpas.ac.cn

${ }^{2}$ University of California, Department of Earth Sciences, Riverside, California, U.S.A. 
${ }^{3}$ National Museum of Natural History, Department of Paleobiology, Washington, D.C., U.S.A.

${ }^{4}$ Boise State University, Department of Geosciences, Boise, Idabo, U.S.A.

${ }^{5}$ University of Calgary, Department of Geoscience, Calgary, Alberta, Canada

Studies of the end-Permian mass extinction have suggested a variety of patterns from a single catastrophic event to multiple phases. But most of these analyses have been based on fossil distributions from single localities. While single sections may simplify the interpretation of species diversity, they are susceptible to bias from stratigraphic incompleteness and facies control of preservation. Here we employ a data set of 1450 species from 18 fossiliferous sections in different paleoenvironmental settings across South China and the northern peri-Gondwanan region, and integrate with high-precision geochronologic data, to evaluate the rapidity of the largest Phanerozoic mass extinction. To reduce the Signor-Lipps effect, constrained opitimization (CONOP) was applied to search for an optimal sequence of first and last occurrence datums for all species and generate a composite biodiversity pattern based on multiple sections. This analysis indicates an abrupt extinction of $62 \%$ of species took place within $200 \mathrm{Ka}$. The onset of the sudden extinction is around 252.3 Ma, just below Bed 25 at the Meishan section. Taxon turnover and diversification rates suggest a deterioration of the living conditions nearly 1.2 Ma before the sudden extinction. The magnitude of the extinction was such that there was no immediate biotic recovery. Prior suggestions of highly variable, multi-phased extinction patterns reflect the impact of the Signor-Lipps effect and facies-dependent occurrences, and are not supported following appropriate statistical treatment of this larger dataset.

\title{
Insect-mediated pollination indicated by Paleogene flowers and insects from Central Europe [oral presentation]
}

\author{
Torsten Wappler ${ }^{1}$, Fridgeir Grimsson ${ }^{2} \&$ Reinhard Zetter ${ }^{2}$ \\ ${ }^{1}$ Rheinische Friedrich-Wilhelms University, Steinmann Institute of Geology, Mineralogy and Palaeontology, Bonn, \\ Germany;E-mail: twappler@uni-bonn.de \\ ${ }^{2}$ University of Vienna, Department of Palaeontology, Vienna, Austria; E-mails: fridgeir.grimsson@univie.ac.at \& \\ reinhard.zetter@univie.ac.at
}

Interactions among species are one of the most important drivers of the ecology and evolution of species. Throughout the last years, interesting insights into Paleogene plant/insect associations from European localities have been obtained. However, one component that was completely disregarded in all of these studies so far are the insect/flower associations. Because of their outstanding preservation quality of not just flowers and insects, but also direct evidence such as pollen-matching and gut content, the investigated localities offer worldwide unique requirements to study insect/flower associations. These are multifaceted and can be examined from botanical, entomological, ecological and evolutionary viewpoints that are often 
summarised under the heading of pollination biology. Given the fact that insect pollination is the dominant method of reproduction of flowering plants, the role of insects in shaping major ecosystems cannot be underestimated.

\title{
An unusual fossil lace bug (Heteroptera: Tingidae) from Green River [poster presentation]
}

\author{
Sonja Wedmann ${ }^{1,2} \&$ Torsten Wappler ${ }^{1,2,3}$ \\ ${ }^{1}$ Senckenberg Research Institute and Natural History Museum, Department of Palaeoanthropology and Messel \\ Research, Frankfurt/M., Germany; E-mail:sonja.wedmann@senckenberg.de \\ ${ }^{2}$ Biodiversity and Climate Research Centre (BiK-F), Frankfurt/M., Germany \\ ${ }^{3}$ Rheinische Friedrich-Wilhelms University, Steinmann Institute of Geology, Mineralogy and Palaeontology, Bonn, \\ Germany; E-mail: twappler@uni-bonn.de
}

A characteristic feature of lace bugs (Tingidae) is the distinctive lacelike network of raised ridges, which is present on the hemelytra and on the pronotum of two of the three subgroups. These subgroups comprise the Cantacaderinae and the Tinginae, while the Vianaidinae have a rather smooth body surface. With more than 2100 extant species, they are widely distributed in the different regions of the world. Lace bugs are not uncommon as fossils and have been described from both amber deposits and sediments dating back to the Mesozoic. An ongoing study of heteropterans from the Eocene Green River Formation (USA) reveal some unusual tingids that show areolate structures and a stenocostal area with transversal veinlets, indicating a closer relation to the Cantacaderinae but antennae appear to be more coreid-like, with an extremely enlarged last segment.

\section{Phyllotaxy in seed cones of Araucaria mirabilis (Middle Jurassic Cerro Cuadrado Petrified Forest, Patagonia, Argentina) - Preliminary observations [posterpresentation]}

\author{
Katrin Weiser ${ }^{1}$, Anna Weigand ${ }^{1}$, Carole T. Gee ${ }^{1}$ \& Ronny Rößler ${ }^{2}$ \\ ${ }^{1}$ Rheinische Friedrich-Wilhelms-Universität, Steinmann-Institut für Geologie, Mineralogie und Paläontologie, Bonn, \\ Germany; E-mail: katrin.weisen@yahoo.de
}

${ }^{2}$ Museum für Naturkunde, Chemnitz, Germany

Although the famous and strikingly beautiful Araucaria mirabilis seed cones of
Patagonia have been known for almost 100 years and their anatomy has been
studied extensively, little is known about the arrangement of seeds within the cone.
The cones occur alongside huge fossil logs and numerous pieces of wood in the
Cerro Cuadrado Petrified Forest in the Middle Jurrasic La Matilde Formation,
Patagonia, Argentina. Using the innovative technique of micro-CT coupled with
3D-imaging with Avizo, the internal structure of the seed cone and the phyllotaxy 
of the seeds can be analyzed nondestructively, that is, without any damage to the fossils. Here we show that while the seeds and, hence, bract/scale complexes are helically arranged in a clockwise manner, other parameters regarding seed phyllotaxy are highly variable. These differences include the number of seed spirals per cone, number of seeds per spiral and number of turns that each seed spiral makes around the cone axis. Factors that do not seem to play a role in determining the number of seeds and the extent of the seed spirals are cone size, maturity, and taxonomy. Possible reasons behind the differences in seed phyllotaxy in Araucaria mirabilis cones remain puzzling.

\section{Isotope and element signatures of carbonates of the late Neoprotero- zoic-early Cambrian Critical Interval in the prelude of the "Cambrian Explosion", S-China and Namibia [poster presentation]}

Franziska Wilsky ${ }^{1}$, Joachim Reitner ${ }^{2}$, Bent T. Hansen ${ }^{1}$, Bettina Wiegand ${ }^{1}$ \& Anton Eisenhauer ${ }^{3}$

${ }^{1}$ Georg-August University, Geoscience Centre, Department of Isotope Geology, Göttingen, Germany;

E-mail:fwilsky@gwdg.de

${ }^{2}$ Georg-August University, Geoscience Centre, Department of Geobiology, Göttingen, Germany

${ }^{3}$ GEOMAR - Helmboltz Centre for Ocean Research, Marine Geosystems, Kiel, Germany

Published data from samples of the Neoproterozoic imply extreme environmental changes, for instance from greenhouse to icehouse conditions, which resulted in two global glaciations during the Neoproterozoic, the older Sturtian and the younger Marinoan glaciation, respectively. Our attention is also focused on the non-global pre-Ediacaran Gaskiers glaciation, which has possibly changed the global ocean chemistry essentially, due to an increased riverine input of carbonate ions and e.g. divalent cations from the eroded hinterland. To trace these geochemical changes, we analyzed carbonates, which derive from central and SNamibia as well as the Yangtze Gorge area in S-China, respectively. These samples were analyzed using TIMS for their $\mathrm{Sr}$ and $\mathrm{Ca}$ isotopic compositions. The results reveal ${ }^{87} \mathrm{Sr} /{ }^{86} \mathrm{Sr}$ ratios ranging between 0.70819 and $0.71028 \pm 2$ for the Chinese samples and for the Namibia samples between 0.707880 and $0.716345 \pm 2$. Stable $\mathrm{Ca}$ isotopes show variations in $\delta^{44 / 40} \mathrm{Ca}_{\text {seawater }}$ from $-1.41 \%$ to $-0.83 \% \pm 0.16 \%$ for samples from Namibia and larger variations for samples from China with $\delta^{44 / 40} \mathrm{Ca}_{\text {seawater }}=-1.58 \%$ to $-0.24 \% 0 \pm 0.18 \%$. Element signatures obtained by ICP-OES and ICP-MS show light variabilities for the investigated samples. Additional unpublished $\mathrm{Sr}, \mathrm{Ca}$ and $\mathrm{C}$ isotope data of dolomites and limestones, which originate from the Fransfontein Ridge (Namibia, Marinoan Chaub-Formation) and the Rasthof-Formation (Sturtian, Chuos-Formation), are included. 


\title{
Jurassic Vertebrates from the Turpan Basin [oralpresentation]
}

\author{
Oliver Wings ${ }^{1,2}$, Thomas Martin ${ }^{3} \&$ Sun Ge ${ }^{4,5}$ \\ ${ }^{1}$ Hannover State Museum, Hannover, Germany; E-mail:dr.wings@gmail.com \\ ${ }^{2}$ Museum of Natural History, Berlin, Germany \\ ${ }^{3}$ Rheinische Friedrich-Wilhelms University, Steinmann Institute of Geology, Mineralogy and Palaeontology, Bonn, \\ Germany; E-mail: tmartin@uni-bonn.de \\ ${ }^{4}$ Ministry of Education, Key Laboratory for the Evolution of Past Life and Environment in Northeast Asia, \\ Changchun, P. R. of China \\ 5 Shenyang Normal University, Paleontological Museum of Liaoning, Shenyang, P. R. of China; \\ E-mail: sunge@jlu.edu.cn
}

In the Central Asian Turpan Basin, large areas of Mesozoic sediments are exposed which had seen very limited paleontological interest for a long time. Fieldwork conducted by the Sino-German Paleontological Cooperation Project in Middle to Late Jurassic fluvial and lacustrine sediments near the county of Shanshan (Xinjiang, NW China) has now vastly improved our knowledge of Mesozoic biota of that remote region.

Excavations as well as screenwashing for microvertebrates revealed a number of diverse vertebrate assemblages, that include remains of hybodont sharks, semionotid fish, ?rhynchocephalians, crocodyliforms, turtles, theropods, sauropods, basal ornithopod and thyreophoran dinosaurs, as well as haramiyid, docodont, and stem zatherian mammals.

Spectacular discoveries are a Middle Jurassic theropod tracksite with positive hyporeliefs of $>150$ tridactyl footprints representing two morphotypes, "Mesa Chelonia", the world's largest fossil turtle taphocoenosis yielding an estimated $>1000$ freshwater "xinjiangchelyid" turtles, and several localities with articulated sauropod remains in the Middle-Late Jurassic Qigu Formation.

\section{Pathologic cascade in the vertebral column of a phytosaur (Archo- sauromorpha) from Halberstadt [oral presentation]}

Florian Witzmann ${ }^{1}$, Daniela Schwarz-Wings ${ }^{1}$, Oliver Hampe ${ }^{1}$, Guido Fritsch ${ }^{2}$ \& Patrick Asbach ${ }^{3}$

${ }^{1}$ Museum für Naturkunde, Leibniz. Institute for Research on Evolution and Biodiversity, Berlin, Germany;

E-mails:florian.witzmann@mfn-berlin.de; d.schwarz-wings@mfn-berlin.deぬ oliver.hampe@mfn-berlin.de

${ }^{2}$ Leibniz. Institute for Zoo and Wildlife Research (IZW), Berlin, Germany; E-mail: fritsch@izw-berlin.de

${ }^{3}$ Charité - Universitätsmedizin, Department of Radiology, Berlin, Germany; E-mail: Patrick.Asbach@charite.de

Pathologies in the skeleton of phytosaurs, Late Triassic archosauromorph reptiles, have rarely been described. CT scans reveal three different pathologies in the vertebral column of a phytosaur individual from Halberstadt, Germany: (1) a congenital block vertebra in the lumbar region, (2) an acquired block vertebra in the thoracic 
region, and (3) osteomyelitis of the anterior endplate of the congenital block vertebra. These pathologies appear to be dependent of each other and are interpreted as a pathologic cascade, starting ontogenetically with the congenital block vertebra and ending with the probably lethal osteomyelitis of its endplate. Formation of the acquired block vertebra can be associated with the presence of the congenital block vertebra, which displaced the loading condition in the vertebral column in a way that also influenced other bones, in particular those vertebrae in the thoracic region in contact with the shoulder girdle. In the same set of arguments, a weakness zone created by the congenital block vertebra in the lumbar region might have led to a larger vulnerability for infection and therefore supported the osteomyelitis of the endplate.

\section{Molecular Paleobiology: on sponges and dinosaurs [keynote presentation]}

\section{Gert Wörheide ${ }^{1,2}$}

${ }^{1}$ Ludwig-Maximilians University, Department of Earth and Environmental Sciences \& GeoBio-Center, Munich, Germany; E-mail:woerbeide@lmu.de

${ }^{2}$ Bavarian State Collections of Palaeontology and Geology, Munich, Germany

Molecular paleobiology studies the evolution of organisms and their environments in space and time by integrating the historical records provided by geological and genomic archives. Here I will give an overview of recent advances in the field and present a few case studies. First, phylogenomics helped to better resolve the early evolution of non-bilaterian animals, a part of the animal tree where the fossil record only provides limited resolution. However, some of the deep nodes remain difficult to resolve, even using large molecular datasets, and some analytical challenges persist. Second, Hexactinellids (glass sponges) are excellent models to reconcile paleontological and molecular phylogenetic evidence to better understand the temporal succession of cladogeneses and character evolution. They have a long and rich fossil record, but for certain taxa paleontological evidence is still scarce or ambiguous. Fossil calibration constraints and the largest hexactinellid molecular phylogenetic data set to date was used to infer crown-group divergence times. Results are largely congruent with interpretations of their fossil record, but also indicate long periods of undocumented evolution for several groups. Third, the evolution of phenotypic variation in extinct taxa can be appreciated by comparatively studying the role of developmental genes in extant organisms. In this context, the role of Hox genes in the anteroposterior patterning and regionalization of the vertebral column in Archosaurs (crocodiles, birds, and dinosaurs) is a prime example. We observed a direct correlation between vertebral Hox code and quantifiable vertebral morphology in modern archosaurs and hypothesize the underlying genetic mechanisms that shaped vertebral evolution in a fossil vertebrate. 


\title{
The Late Miocene Höwenegg Lagerstätte (Hegau, Germany): New Excavations and Insights [oralpresentation]
}

\author{
Dominik Wolf ${ }^{1}$, Hans-Walter Mittmann ${ }^{2}$ \& Raymond L. Bernor ${ }^{3}$ \\ ${ }^{1}$ Forschungsinstitut und Naturmuseum Senckenberg, ROCEEH, Frankfurt/M., Germany; \\ E-mail:d_wolf_palaeo@yahoo.de \\ 2 Staatliches Museum für Naturkunde Karlsrube, Abteilung Biowissenschaften, Karlsrube, Germany; \\ E-mail:mittmann@naturkundeka-bw.de
}

3Howard University,Washington,D.C., U.S.A.; E-mail: rbernor@comcast.net

The Höwenegg locality with its exceptionally preserved Late Miocene (MN9, $10.3 \mathrm{Ma}$ ) vertebrate fauna was originally excavated in the 1950s and 1960s. Since 2003, new and ongoing field work, following promising test excavations between 1985 and 1992, much extended the original quarry. New findings increased the total number of mammalian skeletons to 47 , with the boselaphine Miotragocerus pannoniae (24 skeletons) and the hipparionine horse Hippotherium primigenium (16 skeletons) being the most abundant taxa. The remaining mammal fauna is diverse. Further fossil organisms include Testudo and Trionyx, rare amphibians, and fish besides limnic and terrestrial gastropods and plants. The distribution of all complete and partial skeletons is being visualized in 2-dimensional and 3dimensional reconstructions. Four main stratigraphic levels can be identified, with level 11 having the greatest abundance and diversity of biotic elements. Our renewed field work has sparked new research on the geology and paleontology of this lagerstätte. In particular, the anatomy and paleobiology of Höwenegg Miotragocerus and Hippotherium are currently being re-evaluated.

\section{Unraveling the Beetroot Stone mystery: structural elucidation of the first boron-containing fossil organic pigments [oral presentation]}

\author{
Klaus Wolkenstein ${ }^{1}$, Sun $\mathrm{Han}^{2} \&$ Christian Griesinger ${ }^{2}$ \\ ${ }^{1}$ Georg-August University, Geoscience Centre, Department of Geobiology, Göttingen, Germany; \\ E-mail:kwolken@gwdg.de \\ ${ }^{2}$ Max Planck Institute for Biophysical Chemistry, Department of NMR Based Structural Biology, Göttingen, \\ Germany
}

Specimens of the common calcareous red alga Solenopora jurassica from the Bathonian of Great Britain (Beetroot Stone) and the Oxfordian of France are well known for their characteristic pink colouration. Recent measurements using UVvisible spectroscopy and high-resolution mass spectrometry have shown that the pink colouration of $S$. jurassica from both occurrences is due to the presence of a previously unknown class of boron-containing organic pigments, named borolithochromes. However, because of the tiny amounts of compounds, until recently, no detailed chemical structures could be determined. In order to unravel the nature of 
the enigmatic fossil pigments and their relationship to present-day red algal pigments, individual borolithochromes now were elucidated using the new methodology of microcryoprobe nuclear magnetic resonance spectroscopy. Based on one- and two-dimensional spectra obtained from samples of only about 50 micrograms, the borolithochromes could be determined as tetrahedral boric acid esters with two phenolic ligands, exhibiting a novel carbon skeleton which is not related to those of known present-day pigments.

\section{Ancient reefs - is the past a key to the future ? [keynote presentation]}

\section{Rachel Wood ${ }^{1}$}

${ }^{1}$ University of Edinburgh, School of Geosciences, Edinburgh, U.K.; E-mail: Rachel.Wood@ed.ac.uk

Coral reefs, the most biodiverse, complex and vulnerable of marine ecosystems, face an uncertain future as they continue to respond negatively to anthropogenic climate change, overfishing, pollution, and other human impacts. Marine macroecology, just like palaeoecology, is based on taxonomic diversity data and geographic ranges, providing only a qualitative overview of spatial shifts in species richness, even though we know that community biodiversity, and reef health and resilience, may not always be correlated. The dynamics of life on Earth has been characterized by short bursts of extinction and speciation, interspersed with long periods of relative stasis when turnover of species is far slower. Mass extinctions or regime shifts occur when the ocean, climate or biosphere in some way transgresses a tipping point. We know little as to how such profound ecological disruptions operate and propagate across scales, or whether local or regional tipping points can become globally widespread events. Some theory predicts that those taxa evolving in high biodiversity settings such as reefs may more readily migrate to occupy the vacant niches generated by extinctions, so suggesting that large-scale gradients in biodiversity can be in part controlled by past evolutionary history as well as those ecological factors that control current community diversity. As such, the high evolutionary turnover rates shown by reefs due to repeated mass extinctions might explain their propensity as sites of major evolutionary innovation throughout the Phanerozoic. The climate of the Earth is a major driver of regime shifts, and exhibits a range of dynamic behaviours of interconnection and feedbacks with ecosystems. One hallmark of tipping points is increased autocorrelation in time series, illustrating a slowing down in system responses as a threshold is approached. Past episodes of abrupt climate change show this early warning signal remarkably clearly. 


\title{
A new giant Jurassic dinosaur from Shanshan of Turpan-Hami Basin, Xinjiang, China [oral presentation]
}

\author{
Wu Wenhao ${ }^{1,2}$, Zhou Changfu ${ }^{3}$, Oliver Wings ${ }^{4,5}$, Toru Sekiya ${ }^{6}$ \& Dong \\ Zhiming $2,3,7$ \\ 1 Jilin University, Research Center of Paleontology and Stratigraphy, Changchun, P. R. of China; E-mail: \\ paleovert@jlu.edu.cn \\ ${ }^{2}$ Ministry of Education, Key Laboratory for the Evolution of Past Life and Environment in Northeast Asia, \\ Changchun, P. R. of China \\ 3Shenyang Normal University, College of Paleontology, Shenyang, P. R. of China; E-mail: zhoucf528@163.com \\ ${ }_{4}^{4}$ Hannover State Museum, Hannover, Germany; E-mail: dr.wings@gmail.com \\ ${ }^{5}$ Museum of Natural History, Berlin, Germany \\ ${ }^{6}$ Fukui Prefectural Dinosaur Museum, Fukui, Japan; E-mail: t.sekiya.jlu@gmail.com \\ ${ }^{7}$ Chinese Academy of Sciences, Institute of Vertebrate Paleontology and Paleoanthropology, Beijing, P. R. of China; \\ E-mail:dinodong@sina.com
}

Many Mesozoic vertebrates have been reported from the Turpan-Hami Basin, Xinjiang, Northwest China. In recent fieldwork, an articulated postcranial skeleton of a gigantic sauropod (estimated body length: 30-32 m) was excavated in the Middle Jurassic Qigu Formation near Shanshan. While the excavation is still in progress, the specimen already shows an array of autapomorphies that clearly illustrate that it belongs to a new taxon of Neosauropoda. It is characterized by a ventral keel developed on the penultimate cervical centrum and forming a small semi-circular process under the distal articular facet, last two cervical vertebrae particularly elongated (ratio "length of the last two cervical vertebrae/length of femur and tibia" is 0.63 ), sacricostal yoke excepting the first sacral rib, and extremely robust femur (ratio "transverse width of the distal end/femur length" is 0.33). While phylogenetic analysis places the new taxon as a sister group of Mamenchisaurus, it also shows several diplodocid-like characters: prominent ambiens process of pubis, relatively short hind limb and caudomedial developed fourth trochanter on femoral body.

\section{Reconstruction of paleo-environmental change by microbial lipid biomarkers [keynote presentation]}

Xie Shucheng ${ }^{1}$, Richard P. Evershed ${ }^{2}$, Huang Xianyu ${ }^{1}$, Richard D. Pancost ${ }^{2} \&$ Yanag Huan ${ }^{1}$

${ }^{1}$ China University of Geosciences, State Key Laboratory of Biogeology and Environmental Geology, Wuhan, P. R. of China; E-mail:xiecug@163.com

${ }^{2}$ University of Bristol, School of Chemistry, Biogeochemistry Research Centre and the Cabot Institute, Organic Geochemistry Unit, Bristol, U.K. 
The Asian monsoon has received increasing attention in recent decades, but the monsoon-driven hydrological changes remain largely unknown in Earth history due to the limited proxy of monsoonal rainfall. In the past years, we proposed several microbial proxies to identify paleo-hydrological conditions including the ancient drought in Northwestern China and the flooding events in the middle Yangtze region. The relative abundance of the tetraethers of archaea and bacteria was used to identify the enhanced aridity in association with the uplift of the Tibetan Plateau in the late Miocene (Xie et al. 2012). In central China, the lipid biomarkers (hopanoids) for aerobic microbes are used to trace the variation of the water table in the Dajiuhu peatland in central China. The hopanoid-based reconstruction is further supported by other records in the middle Yangtze region. A significant relation is observed between the proxy-inferred hydrological changes and the temporal transitions of the ancient cultures. The spatial migrations of the ancient settlements are also found to correlate with the hydrological conditions in the middle Yangtze region (Xie et al. 2013). The proxies for paleotemperature were also discussed on the basis of microbial lipid biomarkers. In particular, the previously proposed microbial lipid proxies for paleotemperature will be greatly impacted by the hydrological conditions, with the large deviation being found in the arid and semi-arid regions (Yang et al. 2013). Our work demonstrates the sensitive response of microbial lipids to the hydrological conditions as well as temperature in ancient times.

\title{
Coniopteris hymenophylloides (Brongniart) Seward from the Middle Jurassic of Yaojie, Gansu, western China [oral presentation]
}

\author{
Xin Cunlin ${ }^{1}$, Wan Mingli ${ }^{2,3} \&$ Wang Jun ${ }^{3}$ \\ ${ }^{1}$ Northwest Normal University, College of Geography and Environment, Lanzhou, P. R. of China; \\ E-mail:xincunling@163.com \\ ${ }^{2}$ University of Chinese Academy of Sciences, Beijing, P. R. of China \\ ${ }^{3}$ Chinese Academy of Sciences, Nanjing Institute of Geology and Palaeontology, State Key Laboratory of Palaeobiology \\ and Stratigraphy, Nanjing, P. R. of China
}

Well preserved compressions of Coniopteris bymenophylloides (Brongniart) Seward were collected from the Middle Jurassic Yaojie Formation, Gansu Province, northwestern China. The in situ spores and cuticles of the pinnule epidermis are examined. The fronds are bipinnate. The penultimate rachis is approximately $2 \mathrm{~mm}$ in diameter. Pinnae are linear in form, at least $7 \mathrm{~cm}$ in length. The distances between pinnules are variable. Cleft and lobed pinnules are ovoid or rhombus in shape, with the pinnule base broadest and the apex obtuse. The first basal pinnules of the pinna are usually deformed to form a pendate aphlebia. Fertile and sterile pinnules were preserved separately. Fertile pinnules are linear to lanceolated, with the same width as the sterile ones. The shrinking fertile pinnules are virgulate. Rounded sporangia were attached to the apical part of the fertile pinnules. The in 
situ spores with smooth surfaces are mainly circular triangles with 3 sides of equal length in polar view and a semicircle in equatorial view. They are $27.5 \mu \mathrm{m}$ to $46 \mu \mathrm{m}$ in diameter and $37 \mu \mathrm{m}$ on average. The straight and narrow triletes are about 4/5 length of the radius of the spores. The epidermis of Coniopteris bymenophylloides (Brongniart) Seward is very thin. Normal cells of lower epidermis are rectangular to polygonal. They differ in size with $30-60 \mu \mathrm{m}$ in diameter. Anticlinal walls are straight. Ovoid stomatal apparatuses, consisting of two distinct guard cells and paracytic subsidiary cells, are distributed irregularly. Stomatal pores are oblong, irregularly orientated. The upper epidermal features are still unknown. Based on these microstructural features, it is concluded that Cyathidites medicus Sah \& Jain are spores produced by Coniopteris bymenophylloides (Brongniart) Seward. Meanwhile, it provides taxonomic and stratigraphic information of those dispersed spores. Furthermore, the spatial and temporal distribution of Coniopteris bymenophylloides (Brongniart) Seward is summarized.

\title{
The late Mid Devonian Hujiersite Flora from North Xinjiang, China, and its palaeoenvironment [oral presentation]
}

\author{
Xu Honghe ${ }^{1}$, Wang $\mathrm{Yi}^{1}$, Jiang Qing ${ }^{1} \&$ Feng Jing ${ }^{1,2}$ \\ ${ }^{1}$ Chinese Academy of Sciences, Nanjing Institute of Geology and Palaeontology, State Key Laboratory of Palaeobiology \\ and Stratigraphy, Nanjing, P. R. of China; E-mail: bhxu@nigpas.ac.cn \\ ${ }^{2}$ University of Chinese Academy of Sciences, Beijing, P. R. of China
}

The Hujiersite Flora encompasses the late Mid Devonian plant assemblage of North China. A recent palaeobotanical study of plant fossils from the Hujiersite Formation of the Hoxtolgay Area, Xinjiang, is summarized and the characteristics of the Hujiersite Flora are discussed. Widely distributed Mid Devonian plants are present in the Hujiersite Flora, but on the species level, they also have endemic members. The canopy plants of the forest formed by the Hujiersite Flora are endemic tree-like lycopsids rather than ferns. Depositional, petrological and taphonomical analyses of one of the main localities of the Hujiersite plants, 251 Hill section, are given, suggesting that the palaeoenvironment of the Hujiersite Flora is a series of small meandering rivers or small flood plains on relatively isolated volcanic arcs of the tropics.

\section{Evidence from the Early Cretaceous paleowildfire in Huolinhe Coalfield [oral presentation]}

Xu Yan' ${ }^{1}$ Cui Tong 2

1 Jilin University Museum, Changchun, P. R. of China; E-mail: xyan@jlu.edu.cn

2Jilin University, College of Earth Science, Changchun, P. R. of China 
The study of paleowildfire is a new field in paleoecological research, and has still been rare in China. The present thesis applies the integrated method including coal petrology, paleobotany, palynology, for the study of the paleowildfire event that occurred in Huolinhe during the Early Cretaceous, which was recorded in the coalbearing strata of the Huolinhe Coal-Field. The study focuses on the charcoal from the Lower Coal-bearing Member of the Huolinhe Formation in the Huolinhe Coal-Field as the main object of the study.

Lignite in the Lower Coal-bearing Member of Huolinhe Formation contain abundant charcoal which shows a lamellar stacking characteristic with a thickness of 5-20 mm. Most are macro-charcoal with astatic and nonsorted accumulation; different sizes and prothallial plates. Charcoal is mainly the xylem without the twigs, leaves and fruits.

The author analyzed the composition of the burned plant charcoal fossils representing the Huolinhe paleowildfire event for the first time, and confirmed conifers as the main charcoal in floral composition, including Phyllocladoxylon, Taxoxylon, Protocedroxylon, and Xenoxylon.

Temperature interpretations were derived from charcoal reflectance data. The burn temperatures of various types of paleowildfires in Huolinhe are deduced, showing that the temperature of charcoal in charcoal-coal is higher $\left(475-550^{\circ} \mathrm{C}\right)$, and the temperature of charcoal in peat coal is lower $\left(360-370^{\circ} \mathrm{C}\right)$, and charcoal of lignite is between $442^{\circ} \mathrm{C}$ and $520^{\circ} \mathrm{C}$. Based on these data, it is suggested that the temperature of the forest crown fire is $442-550^{\circ} \mathrm{C}$, with the temperature of the surface fire in some areas being $360-370^{\circ} \mathrm{C}$.

\title{
Bayesian and maximum parsimony phylogenetic analyses of Devonian vascular plants [oral presentation]
}

\author{
Xue Jinzhuang ${ }^{1} \&$ Hao Shougang ${ }^{1}$ \\ 1Peking University, School of Earth and Space Sciences, Beijing, P. R. of China; E-mails:pkuxue@pku.edu.cn \& \\ sghao@pku.edu.cn
}

In order to develop a framework of relationships among the early vascular plants, a dataset for phylogenetic analyses were conducted, with 41 plants across 23 characters. The selected plants include two extant bryophytes as outgroups, and 39 taxa as ingroups, among which there are 16 plants from the Posongchong flora (Early Devonian Pragian) of South China and 23 representative plants from other Devonian floras around the world. The selected characters describe the major features of vegetative and fertile organs of these plants, such as sporophyte independence or dependence, branching type of main axis, xylem strand shape, sporangium shape, and others. Both Bayesian and maximum parsimony phylogenetic analyses were conducted.

The main results are as follows. Cooksonioids and rhynialeans form the paraphyletically arranged stem tracheophytes. Catenalis of the Posongchong flora, 
with an alga-like morphology of planate, dichotomous branching and fan-shaped fertile regions consisting of uniseriate sporangia on the flattened fertile branchlets, is resolved as a unique basal tracheophyte. The renalioids, i.e. Aberlemnia, Hsïa and Renalia, are paraphyletically arranged. These taxa are characterized by similar sporangia shape (flattened, reniform or transverse-elliptical), bilateral symmetry and transverse dehiscence of sporangia, and presence of thickened sporangium valve rim. That they do not form a monophyletic clade is partially because their shared characteristics seem to be pleisiomorphic and have a wider distribution. A clade of Zosterophyllopsida and Adoketophyton forms a sister group to the more "advanced" tracheophytes with primitive leaves or leaf-like structures that are composed of lycopsids (microphylls) and euphyllophytes adding Yunia and Dibrachophyton. Zosterophyllopsida, in the present concept, is supported by four characters: elliptical or strap-shaped primary xylem strand, exarch primary xylem maturation, absence of perforations in thickening bars (a character of G-type tracheids), and rowed arrangement of sporangia along axis. Lycopsida is supported by three characters: microphyll, helical phyllotaxis and exarch primary xylem maturation. The sister-group relationship between zosterophyllopsids and lycopsids suggested by previous studies is not supported in the present analyses. The euphyllophyte clade is supported by three characters: irregular phyllotaxis of vegetative "laterals" (dichotomous pinnule-like appendages or branch-leaf complexes), radial sporangium symmetry, and sporangia associated with specialized fertile structures, leaf-like appendages or megaphylls. Euphyllophytes encompass a basal paraphyly (including Eophyllophyton, Psilophyton primitivum and Psilophyton dawsonii) and a derived clade composed of early ferns, sphenopsids, aneurophytaleans and related taxa. The sphenopsid lineage represented by Estinnophyton is grouped with Ibyka by more or less whorled phyllotaxis, and elongate ovoid sporangial shape. Several characteristics of the Early Devonian Estinnophyton imply an earlier appearance of the sphenopsids. Celatheca forms a sister group to the "advanced" euphyllophytes, i.e., Tetraxylopteris, Polythecophyton and a clade of Rhacophyton and Denglongia. Celatheca is suggested to represent a basal group of the pteridosperm lineage. The lineage of Polythecophyton-Tetraxylopteris (Class Progymnospermopsida) plus Rhacophyton and Denglongia is supported by a lateral sporangium position within the specialized fertile structure and pinnate branching within the specialized fertile structure. This implies that the evolution of the aneurophytalean progymnosperm lineage began during the Early Devonian period. In the present cladistic analyses, the addition of fossil plants from South China shows that the lineages of euphyllophytes are much more complex than preciously understood, and implies that divergence of the euphyllophytes had occurred by late Pragian (Early Devonian).

This work was supported by NSFC (no. 41272018). 


\title{
Diversity dynamics of the Late Silurian-Early Devonian megafossil plants [posterpresentation]
}

\author{
Xue Jinzhuang ${ }^{1} \&$ Hao Shougang ${ }^{1}$ \\ 1Peking University, School of Earth and Space Sciences, Beijing, P. R. of China; E-mails:pkuxue@pku.edu.cn \& \\ sghao@pku.edu.cn
}

The investigation of plant diversity across geological times has been one of the central questions in the field of macroevolution studies. To reveal the diversity dynamics of the early land plants (mainly vascular plants), the present analyses were carried out at the specific and generic levels on megafossils and mesofossils. The stratigraphic range is from the Llandovery (Silurian) to the Emsian (Early Devonian). In total, there are 24 localities of Silurian megafossil plants and 57 localities of Early Devonian megafossil and mesofossil plants. Numbers of genera and species (raw diversity) increased steadily from the pre-Pridoli to Lochkovian, and then suddenly and sharply rose during the Pragian, reaching a diversity peak at 68 genera and 100 species. Diversity declined during the Emsian. The other two indices, the number of observed genera per million years, and the estimated number of genera per million years after standardization for the six studied time intervals, show similar patterns. Both curves show a steady increase before the Pragian, a maximum value in the Pragian, and a decline in the Emsian. In absolute numbers, the genera of the Rhyniopsida emerged in the pre-Pridoli, reached a plateau during the Pridoli to Pragian, and declined during the Emsian. However, the percentage of rhyniopsid genera peaked in the Pridoli and then dropped stepwise through the Lochkovian to Emsian. As to the zosterophyllopsid genera, either the absolute number or the percentage reached the maximum in the Pragian and then decreased in the Emsian. Thus, the replacement of the rhyniopsiddominated floras with zosterophyllopsid-dominated floras through the Pridoli and Emsian appears to have been gradual. The proliferation of lycopsids and euphyllophytes was first recorded in the Pragian and extended into the Emsian.

Comparative morphological studies demonstrate that vegetative and fertile organs of basal lycopsids and euphyllophytes had already diversified during the Pragian, leading to the formation of the diverged different lineages. The Pragian explosion of vascular plant lineages has been proposed as a major evolutionary radiation event (Hao \& Xue 2013: The Early Devonian Posongcbong flora of Yunnan - a contribution to an understanding of the evolution and early diversification of vascular plants; Beijing: Science Press). This event is characterized by the following characteristics: (1) abruptly happened during a very short period, i.e. during the Pragian; (2) appearance of a series of more advanced innovations with respect to configuration and organization of vegetative and fertile organs, before the background of distinct diversification of coevally dominant plant groups (rhyniopsids and particularly zosterophyllopsids); and (3) followed by the emergence of diversified higher taxonomic groups that are either short-lived or have continued to the present day.

This work was supported by NSFC (no. 41272018). 


\title{
Biostratigraphy and lithological gaps in the small shelly faunal succession of East Yunnan [oral presentation]
}

\author{
Ben Yang ${ }^{1}$, Michael Steiner ${ }^{1}$, Li Guoxiang $^{2} \&$ Helmut Keupp ${ }^{1}$ \\ ${ }^{1}$ Free University, Institute of Geological Sciences, Berlin, Germany; \\ E-mails:yangben8@gmail.com; michael.steiner@fu-berlin.de@keupp@zedat.fu-berlin.de \\ ${ }^{2}$ Chinese Academy of Sciences, Nanjing Institute of Geology and Palaeontology, State Key Laboratory of Palaeobiology \\ and Stratigraphy, Nanjing, P. R. of China; E-mail:gxli@nigpas.ac.cn
}

The regional SSF biozones I-III (Anabarites trisulcatus-Protohertzina anabarica Assemblage Zone; Paragloborilus subglobosus-Purella squamulosa Assemblage Zone; Watsonella crosbyi Assemblage Zone) in eastern Yunnan Province (Meishucun, Xianfeng and Huize regions) are modified. The Annelitellus yangtzensis-Obtusoconus honorabilis and Maikhanella cambriana-Oelandiella korobkovi subzones are differentiated in Zone II. Zhijinites longistriatus is used as an index fossil of Zone III. The accumulation of Zhijinites longistriatus at Gezhongwu needs to be restudied as it may belong to Zone III. The distribution of SSFs and the lithological characterization indicates three major events of exposure of the carbonate platform, resulting in sedimentary breaks and possible karstification. A widely distributed gap of Zone II on the Yantze platform is related to the second disconformity. Considering the complexity of the Terreneuvian history as well as the uniqueness of SSF, an integration of sedimentology, geochemistry and palaeontology is needed for future study.

\section{Calibrating the molecular tree with fossil dates [oral presentation]}

\author{
Yang Qun ${ }^{1}$, Sun Xiaoyan ${ }^{1} \&$ Ma Junye ${ }^{1}$ \\ ${ }^{1}$ Chinese Academy of Sciences, Nanjing Institute of Geology and Palaeontology, State Key Laboratory of Palaeobiology \\ and Stratigraphy, Nanjing, P. R. of China; E-mail:qunyang@nigpas.ac.cn
}

Molecular dating of divergence times in the Tree of Life has become an alternative or supplementary common approach to the traditional biochronological studies of the fossil record. In a sense, the molecular dating, comparative analysis of biomolecular sequence data, is not an independent tool for making the evolutionary timescale, because calibration points based on well-established fossil appearance times are normally required. We proposed the term phylochronology (phylogenetic chronology) for studies of molecular dating integrated with fossil records. In our investigation of arthropod and poriferan early divergence times, we found that selection of fossil calibration points are critical in producing stable divergence times and a number of approaches (e.g., cross validation, empirical scaling) have been attempted in selecting the "best" calibration points. We also found that differrent strategies of fossil calibration, meaning the placements of the fossil dates on different nodes of the phylogeny tree in question, may result in substantial differences in the obtained values of divergence times. We suggest that bio- 
molecular data have been quickly accumulating and data analytical techniques becoming ever more sophisticated, fossil calibration studies are relatively immature, should be given greater attention, and play a critical role in obtaining reliable and accurate node ages for the Tree of Life.

\title{
Lopingian plants from the Linxi Formation in the Solun area, Inner Mongolia [oral presentation]
}

\author{
Zhang Dejun ${ }^{1}$, Ding Haisheng ${ }^{1}$ \& Sun Yuewu ${ }^{2,3}$ \\ 1 Jilin University, College of Earth Science, Changchun, P. R. of China \\ ${ }^{2}$ Ministry of Education, Key Laboratory for the Evolution of Past Life and Environment in Northeast Asia, \\ Changchun, P. R. of China \\ ${ }^{3}$ Jilin University, Research Center of Paleontology and Stratigraphy, Changchun, P. R. of China; \\ E-mail:sunyuewn@jlu.edu.cn
}

A lot of well-preserved plants from the Linxi Formation are collected in the Solun area, Inner Mongolia, and consist of 46 species of 22 genera. They are late Permian in age. The flora is characterized by a lot of Angara plants, such as Paracalamites, Comia, Callipteris, Prynadaeopteris, Iniopteris, Noeggerathiopsis, Rufloria, etc. Some Cathysian elements, such as Lobatannularia ligulata, L. multifolia, Fascipteris cathaysiatus, F. densata, Taeniopteris szei, Cladophlebis liulinensis, C. permica etc. are also mixed. This indicates that the present flora is located in the mixed area between the Angara and Cathysian floristic provinces. Based on the comparison with other late Permian floras in northern China, the present flora is beneficial for depicting the location and the evolution of the Xar Moron-Yanji suture zone in the phytogeographic view. The transmigration of tropical and subtropical Cathysian plants to the north indicates that the Paleo-Asian Ocean was closed during the late Permian along the suture zone.

\section{Origins of microspherules from the Permo-Triassic boundary event layers in South China [oralpresentation]}

\author{
Zhang Hua ${ }^{1}$, Shen Shuzhong ${ }^{1}$, Cao Changqun ${ }^{1} \&$ Zheng Quanfeng $^{1}$ \\ ${ }^{1}$ Chinese Academy of Sciences, Nanjing Institute of Geology and Palaeontology, State Key Laboratory of Palaeobiology \\ and Stratigraphy, Nanjing, P. R. of Cbina; E-mail: hzbang@nigpas.ac.cn
}

Over 60 samples from 35 Permian-Triassic boundary event layers in 12 sections in China were collected and analysed searching for microspherules to study possible evidence of extraterrestrial impact or volcanic eruptions. Detailed SEM observations of surface and internal structures and chemical analyses indicate that microspherules from the Hongshuihe section in Laibin, Guangxi and the Huangshi section in Hubei, South China, consist of five different groups in terms of their 
chemical compositions. They are namely iron, ferruginous, iron-rich and iron-poor siliceous and calcareous microspherules. Most of them are modern fly ashes based on morphological characters and chemical compositions.

Microspherules have also been found from event boundary layers at Meishan sections. A careful study on the shapes, microstructure, and chemical composition of these microspherules indicate that they have different origins. The iron microspherules are most likely of terrestrial origin rather than cosmic dusts. Abundant pyrite microspherule and framboidal pyrites are also present at Meishan sections. They are apparently of depositional or diagenetic origins. Calcareous microspherules and hollow organic microspherules are also present and they are clearly of biological origin. The soil samples near the $\mathrm{P} / \mathrm{T}$ boundary layers at Meishan sections also contain abundant fly ashes. Therefore, most of the microspherules previously figured in these sections are possibly from modern contamination.

By contrast, microspherules are not found in the hard tuff layers of the Permian-Triassic boundary at the Xiaochehe Section in Guiyang, the deeply-evacuated samples near the P/T boundary at the Shangsi Section in Sichuan, and the caliche Bed at the Selong Xishan section in Tibet and the mudstone beds in the Dalongkou Section in Xinjiang province, which are far from the industrial areas.

Based on a study of microspherules from the $\mathrm{P} / \mathrm{T}$ boundary beds in South China, neither microspherules of impact origin nor accompanying minerals with impact planar deformation features were found. The microspherules from the $\mathrm{P} / \mathrm{T}$ boundary beds are of multiple origins. Among them, most of the iron and Fe-rich microspherules previously reported are modern fly ashes. The pyrite microspherules and framboidal pyrite are of depositional, biological or/and diagenetic origins. The calcareous microspherules and the hollow organic microspherules are of biological origin.

\title{
Sedimentology and treatment of huge microfossil datasets to recon- struct the palaeoenvironment and palaeoclimate in terrestrial settings: A Mesozoic case study (Junggar and Tarim Basins, NW-China) [oral presentation]
}

\author{
Zhang Jianguang ${ }^{1}$, Jens Hornung ${ }^{1}$, Olaf K. Lenz ${ }^{1}$, Matthias Hinderer ${ }^{1}$ \& Wang \\ Pujun $^{2}$ \\ 1Technical University of Darmstadt, Institute of Applied Geosciences, Darmstadt, Germany; \\ E-mails: zhangjianguang108@126.com; hornung@geo.tu-darmstadt.de; len_@geo.tu-darmstadt.de \& \\ binderer@geo.tu-darmstadt.de \\ 2Jilin University, College of Earth Science, Changchun, P. R. of China; E-mail: wangtj@jlu.edu.cn
}

Adjacent to the Tian Shan in NW China the Junggar and Tarim basins provide a continuous continental record of climatic and tectonic parameters during the entire Mesozoic. This makes them a natural laboratory to study how geodynamic processes interplay with surface topography and climate on a local, regional, and 
global scale. Of overall scientific interest is the role and intensity of the Early Mesozoic mega monsoon system at the easternmost end of Pangea and its evolution with repeated collisional events and increasing continental $v s$. global humidification and rearrangement of atmospheric circulation patterns.

In this study Upper Triassic and lower Jurassic sections in north Tarim and south Junggar basin were investigated in terms of depositional processes and their palaeoenvironmental interpretation. To reconstruct palaeoenvironmental parameters on a regional scale a huge literature-dataset of about 64 papers was evaluated by picking the documented fossil and lithofacies distribution. Therefore a specially designed MS Access database was used, which automatically can crosslink all data. This part of the study focusses on quantitative sporomorph data to identify palaeoenvironmental changes, because palynomorphs are the most abundant microfossil group in this area. Hence, until now, nobody has tried to establish a palaeo-community model based on such a huge database in that region. Therefore, 337 genera of pollen and spores in 283 samples were used covering both basins. A program was compiled to create a cluster analysis, which show very pronounced quantitative sporomorph distribution patterns.

The resulting clusters reveal sporomorph assemblages that correlate well with known sporomorph ecogroups from NW-Europe (Abbink et al. 2004), but also show new or missing members compared to the European ecogroups. In conclusion, specific and unique assemblages could be established which are special for that region and contribute to a better understanding of palaeoecological conditions. Based on the interpretation of these new sporomorph assemblages and their spatial distribution, new palaeoenvironmental maps could be automatically generated in a GIS system. This offers the unique possibility to study the sensitivity of compositional variations of the ecogroup-assemblages, to eliminate misinterpretations of palaeoenvironment and palaeoclimate of single species and to map lithofacies and sporomorph shifts in time and space. As an outcome this dataset will reveal completely new insights into the relationship of climate and tectonic processes in central Asia.

\section{Geological consequences of biological activities [keynote presentation]}

\section{Zhang Xingliang ${ }^{1}$}

\section{${ }^{1}$ Northwest University, Early Life Institute and Department of Geology, State Key Laboratory of Continental Dynamics, Xi'an, P. R. of China; E-mail:xzhang69@nwu.edu.cn}

Life has intimately interacted with the inanimate world since its appearance on the planet Earth some 3.8 billion years ago. This interplay constitutes the basis of the integration between life science and Earth science and finally leads to the renaissance of the cross-discipline geobiology, which parallels geophysics and geochemistry. Nowadays, geobiological research comprises two campaigns. On the one hand, biologists find many metabolic pathways that are actively altering the 
Earth's surface environment in every imaginable habitat and investigate the mechanisms of each metabolism on the molecular level. On the other hand, geologists are searching for biological information from rocks and sediments, and deciphering the past biological activities and their geological consequences. Any metabolic activity, in past and present, inevitably interacts with its environment and thus has environmental effects. Consequently, the processes and consequences of biological activities have been imprinted in rocks and sediments either as physical records or geochemical signals. In this context, I propose a working model for geologists doing geobiological research, which centers on geological consequences of biological activities. Potential research topics may include but are not restricted to: geological importance of the evolution of metabolic diversity in terms of carbon sources, energy sources, and oxidants; the evolution of biomineralization and geological consequences; the evolution of microbial ecosystems and environmental consequences; biogeochemical cycles of elements that are of geobiological importance; geological consequences of biological construction and deconstruction of rocks and sediments; geobiology of critical transitions.

\title{
Cuticles of Lepidopteris leaves in the Upper Permian of Shanxi, China [oral presentation]
}

\author{
Zhang Yi ${ }^{1,2}$, Zheng Shaolin ${ }^{1,2} \&$ Serge V. Naugolnykh [Сергей В. Наугомь- \\ ных; Sergej V. Naugol'nyh] $]^{3}$
}

1Shenyang Normal University, College of Paleontology, Shenyang, P. R. of China;

E-mail:_hangyihzlmb@synu.edu.cn

${ }^{2}$ Ministry of Land \& Resources, Key Laboratory for Paleontological Evolution in Northeast Asia, Shenyang, P. R. of China

${ }^{3}$ Russian Academy of Sciences, Geological Institute, Moscow, Russia

Lepidopteris baodensis Zhang et al., belonging to the Peltaspermaceae family and represented by two ultimate pinnae in the collection under study, was recently discovered at the Baijiagou of Baode, Shanxi, North China, from the Upper Permian Sunjiagou Formation (Zhang et al. 2012). Gross morphologically, the ultimate rachis, the midrib and secondary veins are smooth in the upper surface, whereas in the lower surface they are covered with triangular, trapezoid, rounded, or ligulate blisters, which have been interpreted as subepidermal swellings (Taylor et al. 2009). The cuticles of L. baodensis leaves show that the subepidermal swelling on the ultimate rachis, more or less paired, attaining a maximum length of at least $3 \mathrm{~mm}$ long by $1.5 \mathrm{~mm}$ wide, is composed of ordinary epidermal cells with stomata, forming longitudinal files and numerous groups. Ordinary epidermal cells and stomata in each group are set in a concentric pattern. The subepidermal swellings on a midrib, single or paired, generally $300-500 \mu \mathrm{m}$ long by $300-400 \mu \mathrm{m}$ wide, are also composed of ordinary epidermal cells and stomata, only forming 3-4 groups. Ordinary epidermal cells and stomata in each group are also set in a concentric 
pattern. The subepidermal swelling on a secondary vein single, generally 200 $300 \mu \mathrm{m}$ long by 150-200 $\mu \mathrm{m}$ wide, is composed of ordinary epidermal cells and stomata, forming a concentric pattern. L. baodensis enlarges and supplements our knowledge in taxonomy and anatomy of Lepidopteris as well as the Upper Permian stratigraphy of China. It also provides some new data on the relationship between Euramerican floras and Cathaysian floras in paleoclimate, paleoenvironment and paleogeography.

\title{
Paleoecology of Upper Carboniferous reef-building Chaetetes in North China [oral presentation]
}

Zhang Yongli ${ }^{1}$, Gong Enpu ${ }^{1}$, Guan Changqing ${ }^{1}$, Mark A. Wilson ${ }^{2} \&$ Chen Xiaohong 1

${ }^{1}$ Northeastern University, Department of Geology, Shenyang, P. R. of China; E-mail: zhangyongli@mail.neu.edu.cn

${ }^{2}$ The College of Wooster, Department of Geology, Wooster, Ohio, U.S.A.

Only a few small-scale Pennsylvanian reef mounds developed in North China, and they are distributed mainly in the Benxi area, eastern Liaoning Province. Chaetetes penchiensis and Arachnastraea manchurica are the framework building organisms, but Chaetetes is the most common organism in these reef mounds. We have observed lamellar, hemispherical (mini-domal) and anastomosing lamellar morphologies. Chaetetes employed peripheral, medial and mixed growth strategies to occupy a sufficient living space on the substrate. It favored a shallow, warm, and clear marine environment within the photic zone and had a high tolerance of water movement. Chaetetes was generally smothered and covered by mud. The Chaetetes fossil communities in the Benxi area are characterized by a relatively high species diversity. This is not in accordance with the typical diversity pattern of hard substrate marine communities in the Carboniferous. Because of frequent changes of depositional environment, ecological succession is absent in the community dominated by Chaetetes.

\section{Facies differentiation of the reef complex from the Late Ordovician Lianglitag Formation in Bachu, Tarim, NW China [oral presentation]}

\author{
Zhang Yuanyuan ${ }^{1}$, Li Yue $^{1} \&$ Axel Munnecke ${ }^{2}$ \\ ${ }^{1}$ Chinese Academy of Sciences, Nanjing Institute of Geology and Palaeontology, Nanjing, P. R. of China; \\ E-mail: rhyuanyuan601@126.com \\ ${ }^{2}$ Friedrich-Alexander University Erlangen-Nürnberg, Geo-Center of Northern Bavaria, Erlangen, Germany
}

Metazoanal frameworks were key roles in the Late Ordovician reefs, whereas in the Early and Middle Ordovician, microbial reefs are the dominating reef type. In the Late Ordovician (Katian) Lianglitag Formation, Bachu, Tarim Block, NW China, 
however, three distinct stages of thrombolithic microbial reefs are exposed along the Lianglitag Mountains. They provide insight into understanding the response of reef communities under local controlled factors. In aspect of the biotic structure, microbial carbonate calcareous algae such as Vermiporella are abundant, but also other components, such as fragments of Halysis, brachiopods, molluscs, echinoderms, bryozoans, and trilobites have been found. Reefal units of these three stages are morphologically diverse. The lower and upper reef interval is characterised by widespread microbial carbonates with almost constant thickness. However, sedimentation of the Stage 2 shows a higher diversity of reef-dwelling and -building organisms with abundant Mastopora (probably a green alga). Facies differentiation from algal mounds to a shoal depositional environment from northward to southward is also notable. Successive varied units of carbonate sediments in thickness changed from reef core to reef flank alternations in a distance of several kilometres. Coeval oolitic grainstones completely replace the microbial-dominated mounds southward. Such a reef complex pattern suggests a high-low energy carbonate ramp northward, which exhibits the deposits rapidly shift in space. Identified microbialites of the reef compositions and distinct reef relief suggest middle water energy, and nutrient increase favoured large amounts of microbialites, which controlled the reef development. Local environmental factors are the main causes for the dominance of the microbial carbonates. The Bachu area represents the leeward side of the former platform with a gently dipping slope, and that the microbial reefs and their comparatively sparse metazoan fauna are formed in oligotrophic peritidal conditions, whereas at the wind-ward, steeper edge of the platform (Tazhong area) metazoan reefs flourished in more nutrient-rich water.

\section{Diversity and species abundance patterns of the Early Cambrian (Series 2, Stage 3) Chengjiang Biota from China [oral presentation]}

\section{Zhao Fangchen ${ }^{1}$}

${ }^{1}$ Chinese Academy of Sciences, Nanjing Institute of Geology and Palaeontology, State Key Laboratory of Palaeobiology and Stratigraphy, Nanjing, P. R. of China; E-mail: fczhao@nigpas.ac.cn

Lagerstätten from the Precambrian-Cambrian transition have traditionally been a relatively untapped resource for understanding the paleoecology of the "Cambrian Explosion". Systematic collections of fossil assemblages from narrow stratigraphic intervals of the Chengjiang $(\sim 520 \mathrm{Ma})$ and Burgess Shale $(\sim 505 \mathrm{Ma})$ that provide abundance as well as presence-absence information are now available for comparative analysis. At the Mafang (near Haikou, Kunming City, China) section, where one of the richest Chengjiang fossil deposits exists, fossil specimens were systematically collected from a single quarry covering $58.3 \mathrm{~m}^{2}$ through $2.5 \mathrm{~m}$ thickness. The fossiliferous deposit consists of stacked couplets of millimeter to centimeter thick event mudstone layers (rapid deposition) and background mudstone layers (slow deposition). The sampled section was subdivided into several mutually contiguous 
sampled intervals. Only specimens from event mudstones interpreted as buried alive, based on either soft-part preservation or fully articulated skeletons, were counted. A total of 10,238 fossil specimens from 10 sampled intervals were analyzed, belonging to 100 species representing 11 phyla and 15 ecological categories. Each sampled interval represents an induced time-averaged assemblage of various event (obrution) beds of unknown duration. Overall, the different fossil assemblages are taxonomically and ecologically similar, suggesting the presence of a single community type recurring throughout the Mafang section. The Mafang community is dominated by epibenthic vagile hunters or scavengers, sessile suspension feeders, and infaunal vagile hunters or scavengers, represented primarily by arthropods, brachiopods and priapulids, respectively. Most species have low abundance and low occurrence frequencies, whereas a few species are numerically abundant and occur frequently. Overall, the structure and ecology of the Mafang community is comparable to the middle Cambrian (Series 3, Stage 5) Burgess Shale biota (Walcott Quarry, Canada). This suggests that, despite variations in species identity within taxonomic and ecological groups, the structure and ecology of Cambrian Burgess Shale-type communities remained relatively stable until at least the middle Cambrian (Series 3, Stage 5) in subtidal to relatively deep-water offshore settings in siliciclastic soft-substrate environments.

\section{Complexity and diversity of eyes in Early Cambrian ecosystems: evidence from the Chengjiang Biota [posterpresentation]}

Zhao Fangchen ${ }^{1}$

${ }^{1}$ Chinese Academy of Sciences, Nanjing Institute of Geology and Palaeontology, State Key Laboratory of Palaeobiology and Stratigraphy, Nanjing, P. R. of China; E-mail:fcrbao@nigpas.ac.cn

The pervasiveness, intricacy, and complexity of animal eyes has long attracted the attention of scientists. The diverse types of extant eyes reflect the selective advantages of using light as a source of information throughout evolution. It is largely accepted that proper vision originated in the early Cambrian during the initial radiation of many animal groups, known as the "Cambrian explosion". However, the evolutionary origin and diversity of types of eyes still remains obscure. The availability of Cambrian Konservat-Lagerstätten (e.g., Chengjiang, Burgess Shale) with exceptional preservation offers the possibility to shed new light on the origin of eyes. Here we report the discovery of exceptionally preserved non-biomineralized eyes, preserved together with the body, of a non-trilobite arthropod Cindarella eucalla from the early Cambrian ( $\sim 520$ million years ago) Chengjiang biota, China. The specimen reveals that these early arthropods possessed highly advanced stalked grand compound eyes, each with approximately 2000 ommatidia, which enabled high image resolution and wide-angle range of vision. This arthropod was thus capable of finding food in low light, and even more important, it was able to observe and avoid predators (e.g., Anomalocaris, the giant Cambrian predator), 
which indicates a greatly increased 'arms race' in early Cambrian food webs. An analysis of the distribution of eyes related to life habit, feeding types, and phyla from the Chengjiang biota indicates that the basic types of eye optics within metazoan phyla appeared in the early Cambrian, and that arthropods took the lead in the evolution of 'good vision' which triggered arthropod diversity and domination in the early Cambrian oceans. This supports the hypothesis that origin and evolution of 'good vision' was a key trait that promoted preferential diversification, and formed the foundation of modern benthic ecosystems in the early Cambrian ocean.

\section{Microbialites and microbes near the Permian-Triassic boundary of South China [oral presentation]}

Zheng Quanfeng ${ }^{1} \&$ Cao Changqun ${ }^{1}$

${ }^{1}$ Chinese Academy of Sciences, Nanjing Institute of Geology and Palaeontology, Nanjing, P. R. of China;

E-mail:qfiheng@nigpas.ac.cn

We found microbialites and well-preserved microbes near the Permian-Triassic boundary from three sections in South China. The microbialites developed mainly in four forms: thrombolite, algae-mat dolomite, peloidal limestone and homogeneous dolomite. The microbes or microbial structures mainly include flat algal mats, peloidal micrite, pyritized bead-like cyanobacteria, non-branched long-tubelike cyanobacteria, "Y"-branched networked micro-burrows, bush-like tufts and non-branched short-tube-like cyanobacteria. These microbialites and microbes developed right above the extinction level of the latest Permian, indicating an abnormal environment and ecosystem immediately after the end-Permian mass extinction. And the diversities of the microbialites and microbes decrease from a shallower-water environment to the deeper ones, suggesting a water-depth control on the development of the microbialites and microbes during the Permian-Triassic interval.

Early Triassic trace fossils found from the Xie-jia-cao Section, Guang-an of Sichuan, and their paleoecologic significance [oral presentation]

Zhou Zhicheng ${ }^{1}$, Luo Hui ${ }^{1}$, Li Gang ${ }^{1}$, Helmut Willems ${ }^{2}$, Zhu Youhua ${ }^{1}$, Cai Huawei $^{1}$, Xu Bo ${ }^{1}$, Yang $\mathrm{Hao}^{1}$, Chen Jinua ${ }^{1} \&$ Chen Dishu $^{1}$

${ }^{1}$ Chinese Academy of Sciences, Nanjing Institute of Geology and Palaeontology, Nanjing, P. R. of China;

E-mail: zbichengzhou@botmail.com

${ }^{2}$ University of Bremen, Department of Geosciences (FB5), Bremen, Germany 
17 ichnogenera described in this paper are Arenicolites, Bifungites, Chondrites, Didymaulicbnus, Isopodichnus, ?Monocraterion, Palaeophycus, Pbycodes, Planolites, Psammichnites, Skolithos, Taenidium, Teichichnus, Thalassinoides, Treptichnus, Uchirites and star-like trace fossils. They can be assigned to Cruziana ichnofacies reflecting shallow water environments with soft substrates. Some special trace fossils are found in the stormgenerated sediments: Skolithos in the main storm layer and Planolites and Palaeophycus in the warning storm deposition layer. The opportunistic trace fossils, such as Chondrites, Treptichnus gathering in stripped limestones, are indicative of dysaerobic environments. This presentation also probes into the relationship between the spatial and anachronistic distribution of the trace fossils in the Early Triassic and ocean biotic recovery after the $\mathrm{P} / \mathrm{Tr}$ mass extinction.

\title{
Insight into the Ediacaran Doushantuo Formation, South China [keynote presentation]
}

\author{
Zhu Maoyan ${ }^{1}$, Lu Miao ${ }^{1}$, Yin Zongjun ${ }^{1}$, He Tianchen $^{2} \&$ Joachim Reitner $^{3}$ \\ ${ }^{1}$ Chinese Academy of Sciences, Nanjing Institute of Geology and Palaeontology, State Key Laboratory of Palaeobiology \\ and Stratigraphy, Nanjing, P. R. of China; E-mail:myzbu@nigpas.ac.cn \\ ${ }^{2}$ Nanjing University, Department of Earth Sciences, Nanjing, P. R. of China \\ ${ }^{3}$ Georg-August University Göttingen, Geoscience Centre, Department of Geobiology, Göttingen, Germany
}

The well-exposed Ediacaran Doushantuo Formation spans the critical interval from $635 \mathrm{Ma}$ to $551 \mathrm{Ma}$ immediately after the Cryogenian glaciations. The exquisitely preserved carbonaceous multicellular macrofossils, phosphatized and silicified animal embryos, and putative microscopic cnidarians and bilaterian animals in the Doushantuo Formation witnessed the diversification of multicellular eukaryotes and the advent of animals as aftermath of the Snowball Earth glaciations. Besides these unique palaeontological data, four consistent $\mathrm{C}$ isotope excursions, namely CANCE, WANCE, BAINCE and DOUNCE and two assemblages of the organic-walled microfossils from the intercalated siliciclastic and carbonate sequence of the Doushantuo Formation provide the basis for global stratigraphic subdivision and correlation of the Ediacaran System. Widespread occurrence of seep carbonates and associated microbialites from the post-glacial cap carbonate at the base of the Doushantuo Formation require more complex mechanisms for termination of the Cryogenian glaciations. Element and isotope geochemical proxies indicate an increase of ocean oxygenation in the Doushantuo time, which is concomitant with the advent of animals. This process is well evidenced by the DOUNCE (Doushantuo negative carbon isotope excursion) event, characterized by a large shift in $\delta^{13} \mathrm{C}_{\text {carb }}$ from $+5 \%$ down to $-12 \%$ in the upper part of the Ediacaran Doushantuo Formation. Similarities between the evolutionary pattern and stratigraphic occurrence of the DOUNCE and global Shuram-Wonoka anomalies demonstrate that the DOUNCE represents a great oxygenation event during 
the late Ediacaran, which was closely related to the evolution of macroscopic metazoans.

\title{
The megafossils from the 1600-million-year-old Gaoyuzhuang
} Formation in Yanshan range, North China [invited oral presentation]

\author{
Zhu Shixing ${ }^{1,2}$ \\ ${ }^{1}$ China University of Geosciences, State Key Laboratory of Biogeology and Environmental Geology, Wuhan, P. R. of \\ China; E-mail:1404063125@qq.com \\ ${ }^{2}$ China Geological Survey, Tianjin Institute of Geology and Mineral Resources, Tianjin, P. R. of China
}

The Gaoyuzhuang Formation of the Jixian Group (c.1600 to $1400 \mathrm{Ma}$ ) is a major horizon containing the early Mesoproterozoic megafossils in the Yanshan range, North China. The megafossils are represented by megascopic carbonaceous compressions or films on bedding planes and they occur mainly in the Zhangjiayu Subformation at the middle part of this formation. They are characterised as follows: (1) The Gaoyuzhuang megafossils possess various types of morphology, but also each type of shapes can be seen repeatedly many times. At least 13 morphological genera and 15 morphological species could be identified. (2) According to the complexity in morphology, they could be subdivided into two categories: the simple and the complex. The latter could be represented by the spoon-like and leaf-like type, and show an obvious differentiation of organs. (3) Most are smaller and with a width of only a few millimetres or even less than $1 \mathrm{~mm}$, but a number of gigantic types of fossils, on the order of centimetres or decimetres in width, are predominant in some fossiliferous horizons. (4) Some Gaoyuzhuang fossils exhibit special surface structures, even different multicellular tissues, such as the common pseudoparenchymatous tissues, a part of medullary and cortical tissues, and a few cystocarp-like reproductive tissues, etc.

On the basis of both morphological and cytological evidence, most of these fossils are attributable to a new metaphytic flora predominated by ancient red algae (Rhodophycophyta). The new fossil flora indicates that metaphytes not only existed early in the early Mesoproterozoic but had already developed to a rather high level both in diversity and upsizing. Obviously, these new data have very important significance both for the understanding of the evolution of metaphytes and the reconstruction of the palaeoenvironment in the early Mesoproterozoic.

Late Oligocene to Middle Miocene calcareous nannofossil biostratigraphy of the deepwater well in the northern South China Sea [oral presentation]

Zhu Youhua ${ }^{1}$ 
${ }^{1}$ Chinese Academy of Sciences, Nanjing Institute of Geology and Palaeontology, Nanjing, P. R. of China; E-mail:ybzbu@nigpas.ac.cn

The LW-1 well is located in the Baiyun Depression of the Pearl River Mouth Basin, South China Sea. A total of 170 cutting samples have been analyzed for calcareous nannofossils of this well. Calcareous nannofossils were found in all samples. 48 species and 2 indet. species referred to 17 genera have been identified. According to Martini's zonation scheme for Cenozoic calcareous nannofossils, 5 biozones (or combined zones) can be recognized: (1) NN5. The LAD of Sphenolithus heteromorphus marks the top of Zone NN5 dating to $13.53 \mathrm{Ma}$ (Gradstein et al. 2012). The nannofossil abundance ranges from 637 to 4825 and the simple diversity is about 14 to 24 . The predominant species include Calcidiscus leptoporus, Coccolithus pelagicus, Cyclicargolithus floridanus, Discoaster deflandrei, Helicosphaera carteri, Reticulofenestra Pseudoumbilica, Sphenolithus heteromorphus and many others. (2) NN4. The top of Helicosphaera ampliaperta marks the top of NN4 dating to $15.97 \mathrm{Ma}$ (Gradstein et al. 2004). The nannofossil abundance ranges from 1502 to 4320 and the simple diversity is 16 to 22 . The nannofossil flora is similar to the previous one and composed mainly of Calcidiscus leptoporus, Coccolithus pelagicus, Cyclicargolithus floridanus, Discoaster deflandrei, Helicosphaera ampliaperta, Reticulofenestra minuta, R. pseudoumbilica, Sphenolithus heteromorphus, S. moriformis and others. (3) NN3NN1. The LAD of Sphenolithus belemnos marks the top of Zone NN3, dating to 17.95 Ma (Gradstein et al. 2012). The top of NN2 is marked by the LAD of Triquetorbabdulus carinatus, Martini (1971) took the FAD of Discoaster druggii to mark the top of NN1. However, the FAD events are not applicable for cuttings samples. Triquetorbabdulus carinatus was not recorded in the studied well, we suggest assigning this interval to NN3-NN1. The nannofossil abundance ranges from 42 to 7560 and the simple diversity is 4 to 19. The main species are Coccolithus pelagicus, Cyclicargolithus floridanus, Helicosphaera carteri, Sphenolithus belemnos, S. conicus, S. dissilimis, S. moriformis and others. (4) NP25. The top of NP25 is marked by the LAD of Sphenolithus ciperoensis. The nannofossil abundance ranges from 289 to 3252 and the simple diversity is 5 to 11. Coccolithus pelagicus, Cyclicargolithus floridanus, C. abisectus, Dictyococcites bisectus, D. scrippsae, Discoaster deflandrei, Sphenolithus ciperoensis are common species in the flora. (5) NP 24. The LAD of Sphenolithus distentus marks the top of Zone NP24 dating to $26.84 \mathrm{Ma}$ (Gradstein et al. 2012). The nannofossil abundance ranges from 1 to 4789 and the simple diversity is 1 to 11 . Coccolithus pelagicus, Cyclicargolithus floridanus, Dictyococcites bisectus, D. scrippsae, Sphenolithus ciperoensis, S. distentus, S. predistentus, S. moriformis, Zygrhabilithus bijugatus and others are the major components in the flora.

According to the nannofossil marker species, the Middle Miocene/Lower Miocene and the Lower Miocene/Upper Oligocene boundary are discussed in this paper.

This study was supported by the Natural Science Foundation of China (No. 41272014). 


\section{Index of Authors}

Aboussalam, Sarah Z............ 13, 19, 158

Adatte, Thierry

33

Alberti, Matthias

13,28

Albrecht, Christian 135

Altner, Melanie $.14,132$

Altumi, Muftah Mahmud

.. 41

Amler, Michael R. W $.14,120$

Ansorge, Jörg .127

Ariztegui, Daniel .66

Arratia, Gloria . 149

Asbach, Patrick 186

Ashraf, A. Rahman 161

Atwood, Robert C. . .16

Aver'ānov, Aleksandr O. Averianov

Аверьянов, Александр О. Averianov

Averianov, Alexander O. 116

Baars, Christian. 15,16

Baidder, Lahcen .. 19

Bannister, Jennifer M. .84

Baud, Aymon .67

Bauer, Kathleen 17,18

Baumbach, Tilo 145

Bechly, Günther .85

Beckemeyr, Roy 149

Becker, R. Thomas.......13, 19, 40, 51, 63, 68, 158

Becker, Stefanie

Beimforde, Christina 20,141

Belahmira, Abouchouaib. 146

Bellou, Nikoleta

Benfrika, El Mustafa .13
Berensmeier, Michaela............................ 20

Bernasconi, Stefano M........................... 66

Berning, Björn ......................................... 21

Bernor, Raymond L................................ 188

Béthoux, Olivier..............................34, 174

Bevins, Richard ...................................... 16

Birgel, Daniel .............................................67 67

Blumenberg, Martin................................. 39

Bodin, Stéphane......................................... 31

Bönisch, Eberhard ..................................... 90

Bomfleur, Benjamin.......................22, 145

Bover-Arnal, Telm .................................. 33

Brachert, Thomas C................................ 22

Bradler, Sven.......................................... 174

Brandner, Rainer .......................................67

Brenckle, Paul........................................ 175

Briggs, Derek E. G. .............................. 164

Brink, Kirstin ....................................... 157

Brinkkötter, Janka J.............................. 23

Brocke, Rainer ........................................ 24

Brocklehurst, Neil ................................. 24

Brosig, Andreas ...................................... 167

Bucher, Hugo.......................................... 145

Buchwitz, Michael ................. 25, 50, 167

Buckley, Lisa G. .................................. 134

Cai Chenyang............................................. 25

Cai Huawei.........................................26, 204

Cao Changqun........................ 27, 197, 204

Chellouche, Patrick.................................. 28

Chen Bo .................................................... 29

Chen Dishu..........................................30, 204

Chen Feng.............................. 95, 102, 159 
Chen Jin 109

Chen Jinua 204

Chen Jun .29

Chen Shanqin 176

Chen Wei 109

Chen Xiaohong. $30,62,201$

Chen Yuxuan 48

Chen Zhe $.62,176$

Chorazy, Wawrzyniec .. 31

Chu Daoliang..... 31,32

Clark, James M 83

Conran, John G. . .84

Corradini, Carlo 170

Corriga, Maria G. 170

Cors, Jean .. 33

Crowley, James L 182

Cui Tong 192

Cui Yingying $.34,174$

Danto, Marylène .. 34

Davey, Niki. 128

De Baets, Kenneth .. 35

Dellantonio, Elio .. 92

Ding Haisheng 197

Ding Jiahui .48

Ding Weihua 111

Dinis, Jorge L . .74

Dörfelt, Heinrich 20, 141

Dong Chong .. 36

Dong Liping $.37,176$

Dong Qiang 173

Dong Zhiming. 190

dos Santos Rolo, Tomy Santos Rolo

Drapatz, Heike. 140

Dries, Ramona .......................................... 93

Duan Ye

Duda, Jan-Peter $.39,133$

Dunlop, Jason. 139
Dynowski, Janina F 40

Eichholt, Stephan 13,40

Eisenhauer, Anton 185

El Hassani, Ahmed 13, 19

Elicki, Olaf .41, 90

El Kamel, Fouad. 13

Engelbrecht, Andrea ............................... 42

Ernst, Andrej. 42

Erwin, Douglas H 182

Evershed, Richard P. 190

Färber, Claudia .43

Fahlke, Julia M. 43

Falk, Daniel. 44

Falkenstein, Julian 45

Fatka, Oldřich 45

Fechner, Regina. $.45,46$

Feldberg, Kathrin 20

Feng Jing. $.82,192$

Feng Weimin..... 46

Feng Zhuo $.48,173$

Fischer, Jan 49, 50, 52, 89, 167, 168

Fischer, Tobias 51

Förderer, Esther-Meena ........................... 51

Foth, Christian ………………………...... 52

Franeck, Franziska .................................. 52

Freiwald, André........................................ 43

Frenzel, Peter............................................. 53

Frey, Eberhard .......................................... 93

Frijia, Gianluca.......................................... 20

Fritsch, Guido......................................... 186

Fritz, Hans-Joachim .................................... 54

Fröbisch, Jörg ............................ 24, 55, 77

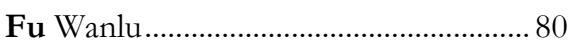

Fuchs, Dirk …............................................ 55

Fürsich, Franz T....................... 13, 28, 70

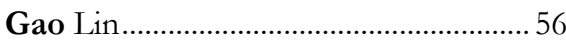

García-Barrera, Pedro............................ 142 
Garten, Nicole 57

Gee, Carole T.

$.57,184$

Gegg, Lukas 105

Gehler, Alexander. $.57,58,129,131$

Geng Binghe

$.59,109$

Gensch, André. . .93

Ghobadi Pour, Mansoureh .16

Gierl, Christoph $.59,105$

Gingerich, Philip D. . .57

Gitter, Frank .60

Göddertz, Peter . .72

Goedert, James L .87

Gößling, Rainer . .45

Golubić, Stjepko 60,61

Gong Enpu . $30,62,201$

Grauvogel-Stamm, Léa .17

Griebler, Eva-Maria . .87

Griesinger, Christian 188

Grimsson, Fridgeir 183

Gröhn, Carsten . .64

Gross, Martin .60

Gu Junjie. .34

Guan Changqing 62, 201

Guan Chengguo $.62,176$

Gube, Matthias $.20,141$

Hagdorn, Hans. . .40

Hampe, Oliver. $.43,186$

Hansen, Bent T. 185

Hao Shougang. ..193, 195

Hao Weicheng. .. 80

Hartenfels, Sven 19,63

Hartl, Christoph .. 64

Hastings, Alexander K .65

Haude, Reimund 170

Haug, Carolin .. 71

Haug, Joachim T. $.65,71$

Hauschke, Norbert . .78

He Tianchen
He Wen 176

Heimhofer, Ulrich ... $33,66,74$

Heindel, Katrin 67

Heinrichs, Jochen $64,67,141$

Helling, Stephan. $.68,158$

Henderson, Charles M. 182

Henderson, Jane 16

Hengst, Anja 113

Herbig, Hans-Georg 68, 69

Hethke, Manja 70

Hielscher, Romina Christin..................... 70

Hinderer, Matthias .................................. 198

Hipsley, Christy A..................................... 71

Hitz, Johanna .68

Hochuli, Peter A............................33, 145

Hoek Ostende, Lars W. van den........ 88

Hörnig, Marie K .71

Hoff, Corinna $78,93,94$

Hoffmann, René $.72,98$

Hofmann, Richard 41,73

Horacek, Micha. 67

Horikx, Maurits ......................................... 74

Hornung, Jahn J...................................... 74

Hornung, Jens ........................................ 75

Hou Lianhai................................................ 56

Hu Dongyu .................................................. 56

Hu Keyi................................................. 175

Huang Baoyu ............................................ 26

Huang Diying .................................25, 104

Huang Qisheng ..................................... 180

Huang Xianyu........................................... 190

Huang Yunfei ............................................ 103

Huck, Stefan .............................................. 33

Ifrim, Christina......................................... 76

Jackson, Daniel J....................................... 20

Jacques, Frédéric M. B........................ 174

Jäger, Kai ...................................................... 77 
Jansen, Maren ........................................ 77

Janussen, Dorte. 78,79

Ji Cheng. 80

Ji Zhansheng 104

Jiang Baoyu .. 70

Jiang Dayong. .. 80

Jiang Qing. $.82,192$

Jiang Zikun $. .165,180$

Joachimski, Michael M. .. 29

Jones, Hefin. 16

Jones, Marc E. H. .. 37

Joyce, Walter G. $.83,124$

Kaestner, Anders 93

Kahsnitz, Michaela . .83

Kammerer, Christian F. . .77

Kamp, Thomas van de 145

Kaulfuss, Uwe. 84,86

Kear, Benjamin P. .75

Kennedy, Elizabeth M. .. 84

Kern, Andrea K. . .85

Kerp, Hans 145

Kettunen, Elina. .86

Keupp, Helmut $.55,196$

Kiecksee, Anna Philie . .86

Kiel, Steffen .87

Kiessling, Wolfgang. .100, 119

Klein, Nicole. 87

Klietmann, Johannes . .. 88

Klug, Christian .. 35

Kneidl, Volker. .. 24

Könen, Janine .88

Koenigswald, Wighart von 148,151

Kogan, Ilja $50,52,89,167$

Konijnenburg-van Cittert, Johanna .... Van Konijnenburg-van Cittert

Kossler, Annette $.90,135$

Koşun, Erdal . .67

Kovar-Eder, Johanna .85
Kranendonk, Martin Van Kranendonk

Kreher, Christian......................................... 90

Kretzschmar, Ralph.............................. 113

Krings, Michael.......................... 17, 18, 87

Kriwet, Jürgen ............................ 42, 50, 91

Krystyn, Leo .............................................. 67

Kürschner, Wolfram M........................ 145

Kullmer, Ottmar...................................... 151

Kustatscher, Evelyn....17, 18, 91, 92, 153

Laaß, Michael $78,93,94$

Lagnaoui, Abdelouahed ........................ 146

Lai Xulong ............................................... 29

Laibl, Lukáš ............................................... 45

Lambert, Lance L..................................... 29

Lang Jiabin.................................................. 95

Langer, Martin R. ..............................51, 88

Lautenschlager, Stephan................95, 96

Lechner, Thomas ..................................... 105

Lee, Daphne E...................................84, 86

Lee, Seong-Joo ............................................. 61

Lehnert, Oliver .......................................... 97

Lemanis, Robert......................................... 98

Lenz, Olaf K. ......................................... 198

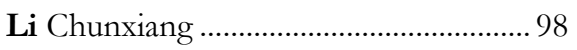

Li Gang........................................................ 204

Li Guoxiang .......................................99, 196

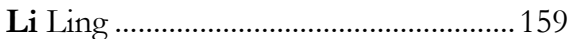

Li Liqin ..........................................99, 180

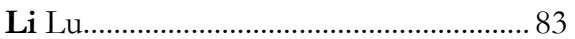

Li Ning........................................................ 111

Li Qijian.................................................... 100

Li Ruiyun..........................................101, 159

Li Tao ..........................................102, 159

Li Xiangchuan............................................ 159

Li Xuegang .............................................. 111

Li Yue ...............................................100, 201

Li Yunfeng ....................................102, 159 
Liang Lei................................................ 103

Liao Huanyu 104

Liao Weihua............................................. 104

Licht, Martin ............................................ 50

Liebl, Dorothea ...................................... 105

Lin, Jih-Pai ............................................ 106

Lin Liugen.............................................. 26

Lin Ribai ................ Lin, Jih-Pai

Lin Wei.................................................. 107

Lindqvist, Jon K...................................... 84

Litt, Thomas .............................................. 169

Liu Dongxu .............................................. 107

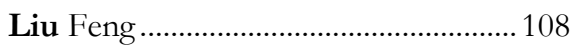

Liu Jianrong ............................................. 48

Liu Jinyi ....................................................... 109

Liu Wei.................................................... 110

Liu Zhaosheng ............................................ 99

Liu Zhongyun........................................... 109

Löhr, Elena .............................................. 105

Looy, Cindy …………………………....... 87

Lou Yushan................................................ 109

Lu Miao ......................................................... 205

Lucas, Spencer G. .........................146, 168

Lü Xiaoxia................................................. 111

Luo Cui..................................................... 112

Luo Hui ..................................... 30, 112, 204

Luo Zhexi..................................................... 77

Luthardt, Ludwig .................................. 113

Ma Fujun 159

Ma Junye $.114,196$

Ma Ning..... 109

Mähler, Bastian ......................................... 115

Magnus, Michael..................................... 90

Maier, Wolfgang ..................................... 140

Maletz, Jörg............................................. 115

Mángano, Gabriela ................................... 41

Maraun, Mark ................................... 84, 86

Martens, Thomas .................................. 154
Martill, David M....................................... 66

Martin, Thomas........23, 70, 77, 115, 116, 151, 161, 186

McLoughlin, Stephen ............................. 22

Meissner, Philipp …………………....... 117

Meister, Patrick............................................ 66

Menéndez, Silvia ............................136, 137

Merbitz, Mathias............................113, 119

Miao Yuyan .............................................. 160

Mildenhall, Dallas C................................ 84

Mills, Sadie............................................... 128

Mittmann, Hans-Walter ......................... 188

Mörs, Thomas ...................................42, 117

Mohtat, Taybeh ........................................ 67

Moisan, Philippe.....................................167

Moreno-Eiris, Elena......................136, 137

Mosbrugger, Volker ....................160, 161

Motani, Ryosuke........................................ 80

Mudroch, Alexander........... 118, 134, 157

Müller, Johannes........................................ 71

Munnecke, Axel............................126, 201

Mutterlose, Jörg ..............................31, 117

$\mathrm{Na}$ Lin...................................................... 119

Na Yuling................................................. 159

Nagel, Doris......................................88, 167

Nascimbene, Paul C............................... 141

Naugol'nyh, Sergej V. Naugolnykh

Наугольных, Сергей В. Naugolnykh

Naugolnykh, Serge V.............................200

Nebelsick, James H........................40, 85

Nemirovs'ka, Tamara I. Nemyrovska

Немировська, Тамара. I. Nemyrovska

Nemyrovska, Tamara I. ........................ 122

Nohejlová, Martina .................................. 45

Nützel, Alexander .........................120, 152 
Nyhuis, Christian J............................. 120

Nylinder, Stephan

Oliver, Graham

Orr, Patrick J.

Pack, Andreas 57

Pancost, Richard D. 190

Pandey, Dhirenda K. .. 13

Peckmann, Jörn .. 67

Penk, Stefanie B. R 105, 132

Penney, David 122

Perejón, Antonio 136,137

Perrichot, Vincent. . .84

Piller, Werner E. . .60

Piñeiro, Graciela 157

Pippèrr, Martina 105

Preusse, Marvin 167

Prokop, Jakub 34

Pyko, Ines

Qi Yuping. 122, 175, 179

Qie Wenkun

Qu Haiying

Rabi, Márton $.83,124$

Radtke, Gregor 125

Radtke, Gudrun 60,61

Radtke, Jens 126

Rana, Rajendra S 141

Rasmussen, Cornelia. 132

Rasser, Michael W. 85

Raufuß, Ingo 90

Reguero, Marcelo .42, 117

Reich, Mike 129, 130, 131 $7,8,58,126,127,128$,

Reichenbacher, Bettina 105, 132

Reisz, Robert R. 14,59 77
Reitner, Joachim .......7, 8, 20, 39, 79, 130, 133, 137, 138, 141, 142, 185, 205

Ren Dong........................34, 134, 174, 182

Richoz, Sylvain ......................................... 67

Richter, Ute...................................118, 134

Riedel, Frank............................................. 135

Riegel, Walter.....................................24, 39

Rieppel, Olivier ......................................... 80

Rikkinen, Jouko .................20, 64, 86, 141

Rinehart, Larry ....................................... 146

Rintelen, Thomas von............................ 135

Ritsche, Indira ........................................... 43

Roček, Zbyněk........................................... 37

Rodrigues, Pablo Gusmão..................... 140

Rodríguez-Martínez, Marta ..............136, 137, 138

Rösler, Horst ................................................ 90

Rößler, Ronny ....................... 113, 139, 184

Rogers, Rachael ........................................ 16

Romero, Rosemary ................................... 87

Roth-Nebelsick, Anita......................40, 85

Ruf, Irina ...............................140, 148, 150

Rummel, Michael ..................................... 88

Rust, Jes .................................................... 140

Rytina, Marie-Kristin ......................63, 158

Saber, Hafid............................................. 146

Sachs, Sven................................................ 75

Sadler, Peter M.......................................... 182

Sadowski, Eva-Maria .......................86, 141

Sánchez-Beristain, Francisco .............. 142

Sander, P. Martin .................................... 155

Sanmugaraja, Mayuran ......................... 142

Santos Rolo, Tomy dos ........................ 145

Schäfer, Nadine .............................133, 141

Schellhorn, Rico ..............................142, 143

Schlüter, Nils ............................................ 143

Schmidt, Alexander R........20, 64, 84, 86, 141, 144 
Schmidt, Mareike .................................. 135

Schmied, Heiko 145

Schneebeli-Hermann, Elke. 145

Schneider, Jörg W. $34,50,52,113$ 146, 147, 149, 167

Schneider, Jürgen 61

Schneider, Marcus. 90

Schöne, Bernd R. 170

Scholze, Frank $146,147,167$

Schubert, Anne. 148

Schützinger, Sandra 105

Schultheiß, Roland 135

Schultz, Cesar Leandro 140

Schultz, Julia A. 70,149

Schultze, Hans-Peter 149

Schulz, Maria 149

Schwark, Lorenz 66

Schwarz, Cathrin $42,91,150$

Schwarz-Wings, Daniela .46, 186

Schweigert, Günther 85

Schwermann, Achim H..... 115, 145, 151

Schwermann, Leonie. 151

Seilacher, Adolf. 11,12

Sekiya, Toru 190

Senowbari-Daryan, Baba 152

Seuss, Barbara 152

Seyfullah, Leyla J. $20,141,152,153$

Shelton, Christen D. 154, 155

Shemang, Elisha 135

Shen Shuzhong. $27,29,182,197$

Shen Yanbin 104

Sheng Qingyi $.156,175$

Shi Xiao 31,32

Shi Yukun 156

Shu Junwu. 178

Simon, Klaus .. 39

Singh, Hukam 141

Siveter, David 164

Siveter, Derek 164
Skawina, Aleksandra ................................ 35

Skrzycki, Piotr ............................................. 89

Solarczyk, Alexandra ............................. 157

Sombke, Andy .......................................... 71

Song Haijun ........................................31, 32

Song Jinming .......................................... 111

Spillards, Deborah ................................. 16

Spindler, Frederik........118, 146, 157, 167

Stachura-Suchoples, Katarzyna ........... 85

Stegemann, Tanja R. .......... 128, 130, 131

Steiner, Michael ......................................... 196

Stichling, Sören ....................................... 158

Stinnesbeck, Wolfgang .......................... 76

Sun Bainian ............................. 36, 101, 159

Sun Chunlin .......................... 102, 159, 161

Sun Ge..........116, 124, 160, 161, 164, 186

Sun Han.................................................... 188

Sun Xiaoyan ...................................162, 196

Sun Yuanlin.................................................. 80

Sun Yuewu ......................................162, 197

Sun Zuoyu..................................................... 80

Sutton, Mark...................................163, 164

Sverdlova, Nina ....................................... 45

Tambussi, Claudia ................................... 42

Tan Xiao ................................................... 164

Taylor, Paul D............................................ 21

Taylor, Wilson A. .................................... 153

Thiel, Volker ............................................. 39

Tian, Li................................................... 103

Tian Mingli ............................................... 26

Tian Ning..........................................165, 180

Tintori, Andrea ........................................... 80

Tischlinger, Helmut .............................. 126

Tötzke, Christian ....................................... 40

Tong Jinnan.......................31, 32, 103, 166

Trümper, Steffen...................................... 146

Tütken, Thomas ...................................... 170

Tuovila, Hanna .......................................... 20 
van de Kamp, Thomas -...... Kamp

van den Hoek Ostende, Lars W. Hoek Ostende

Van Konijnenburg-van Cittert, Johanna H. A. 18,92

Van Kranendonk, Martin 133

Veitschegger, Kristof... 167

Voigt, Sebastian $.25,52,89,167,168$

von Koenigswald, Wighart.

Koenigswald

von Rintelen, Thomas...

\section{Rintelen}

Voss, Manja 168

Vossel, Hannah 169

Walliser, Eric O. 170

Walliser, Otto $\mathrm{H}$ 170

Wan Bin .62

Wan Chuanbiao. 162

Wan Mingli $.171,191$

Wan Xiaoqiao 123

Wang Bo 172

Wang Chengyuan .. 95

Wang Hongmei. 173

Wang Jun 171, 173, 191

Wang Maomin. 174

Wang Pujun 198

Wang Qiujun 159

Wang Qiulai. 175

Wang Shiqi 176

Wang Wei 62, 176, 182

Wang Weiming 178

Wang Xiangdong .29, 123, 179, 182

Wang Xin 180

Wang $\mathrm{Yi}$ $.82,192$

Wang Yongdong..........9, 10, 99, 165, 180

Wang Yongjie 182

Wang Yuan. 37

Wang Yue 182

Wappler, Torsten $.183,184$

Ward, Dustin 158
Ware, David.............................................. 145

Wedmann, Sonja .................................... 184

Wei Haibo ..................................................... 48

Weigand, Anna ......................................... 184

Weiser, Katrin ............................................ 184

Weyer, Dieter ............................................. 14

Wiegand, Bettina ...................................... 185

Wiese, Frank................................................ 76

Wilby, Philip R....................................... 55

Wilde, Volker ............................................. 24

Willems, Helmut..................................83, 204

Wilsky, Franziska...........................133, 185

Wilson, Mark A................................21, 201

Wings, Oliver ...................20, 44, 116, 124 , 186, 190

Wisshak, Max............................................... 43

Witzmann, Florian ..........................34, 186

Wörheide, Gert....................................... 187

Wolf, Dominik......................................... 188

Wolkenstein, Klaus................................. 188

Wood, Rachel ............................................ 189

Wotte, Thomas............................................. 69

Wu Guichun............................................... 104

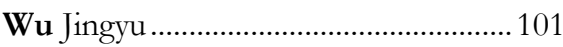

Wu Wenhao ................................................ 190

Wuttke, Michael.......................................115

Xi Dangpeng .............................................. 123

Xia Xuhua .................................................. 162

Xiang Xing............................................... 173

Xiao Liang................................................. 159

Xie Shucheng...................................111, 190

Xie Xiaoping ............................................... 180

Xin Cunlin..................................................... 191

Xu Bo...............................................112, 204

Xu Honghe........................................82, 192

Xu Xiaohui.........................................36, 159

Xu Xing ...............................................56, 83

Xu Yan........................................................ 192 
Xue Jinzhuang 193,195

Zhang Qinghai .83

Zhang Wei $.59,109$

Yan Gao 162

Zhang Wu 165

Yanag Huan 190

Yang, Ben . 196

Zhang Xingliang. 110, 199

Yang Changbing 111

Zhang Yi .164, 200

Yang $\mathrm{HaO}$ 204

Yang Huan 111

Yang Jiyuan. .. 48

Yang Qun 9,10

Yang Yang 111

Yang $\mathrm{Yi}$ .. 36

Yin Zongjun. 205

Yu Jianxin 31,32

Yuan Dongxun .. 29

Yuan Huamao

111

Yuan Xunlai $.62,176$

Yun Yuan 173

Zachow, Stefan .98

Zetter, Reinhard 183

Zhang Dejun 197

Zhang Haichun 172

Zhang Hua 197

Zhang Jianguang 198

Zhang Yichun 182

Zhang Yongli $.62,201$

Zhang Yuanyuan 201

Zhao Fangchen 202, 203

Zhao Guowei. 162

Zhao Zhongyi.. 109

Zheng Fang .59, 109

Zheng Quanfeng 27, 197, 204

Zheng Shaolin 200

Zhou Changfu 107, 124, 190

Zhou Chuanming .62, 176

Zhou Jianping. 173

Zhou Zhicheng 204

Zhu Maoyan. 39, 205

Zhu Shixing 206

Zhu Xianggen .. 26

Zhu Youhua. 204, 206

Ziegler, Reinhard .. 85

Zierold, Thorid 139

Zhang Mingyuan .. 27 170

\section{Note:}

According to the ICZN and the ICN (ICBN), the mentioned or listed new taxa in the present abstract volume are not valid. 
Exceptionally preserved fossils from Fossil Lagerstätten contribute greatly to resolving details on the history of life on Earth. For the first time, the "Paläontologische Gesellschaft" (PalGes) and the "Palaeontological Society of China" (PSC) combined forces to jointly present an international conference aimed to highlight and encourage the study of exceptionally well-preserved fossil sites worldwide. The conference focused on all aspects of palaeontology and geobiology, also incorporating related fields like biogeochemistry, biology, sedimentology and stratigraphy. The present volume contains the abstracts of more than 275 lectures and posters presented during the joint international conference "Palaeobiology \& Geobiology of Fossil Lagerstätten through Earth History". This year's conference was held at the northern campus of the Georg-August University in Göttingen, Germany, from September 23-27, 2013. More than three hundred palaeontologists, biologists, geologists and other scientists and researchers from sixteen countries, mainly from Germany and the P. R. of China, participated.

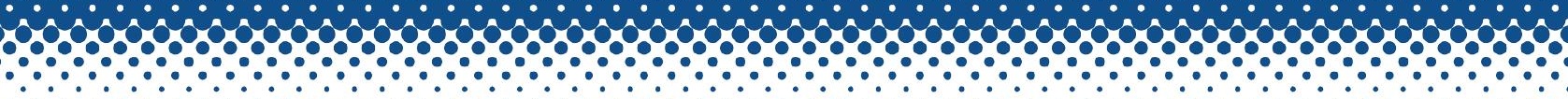

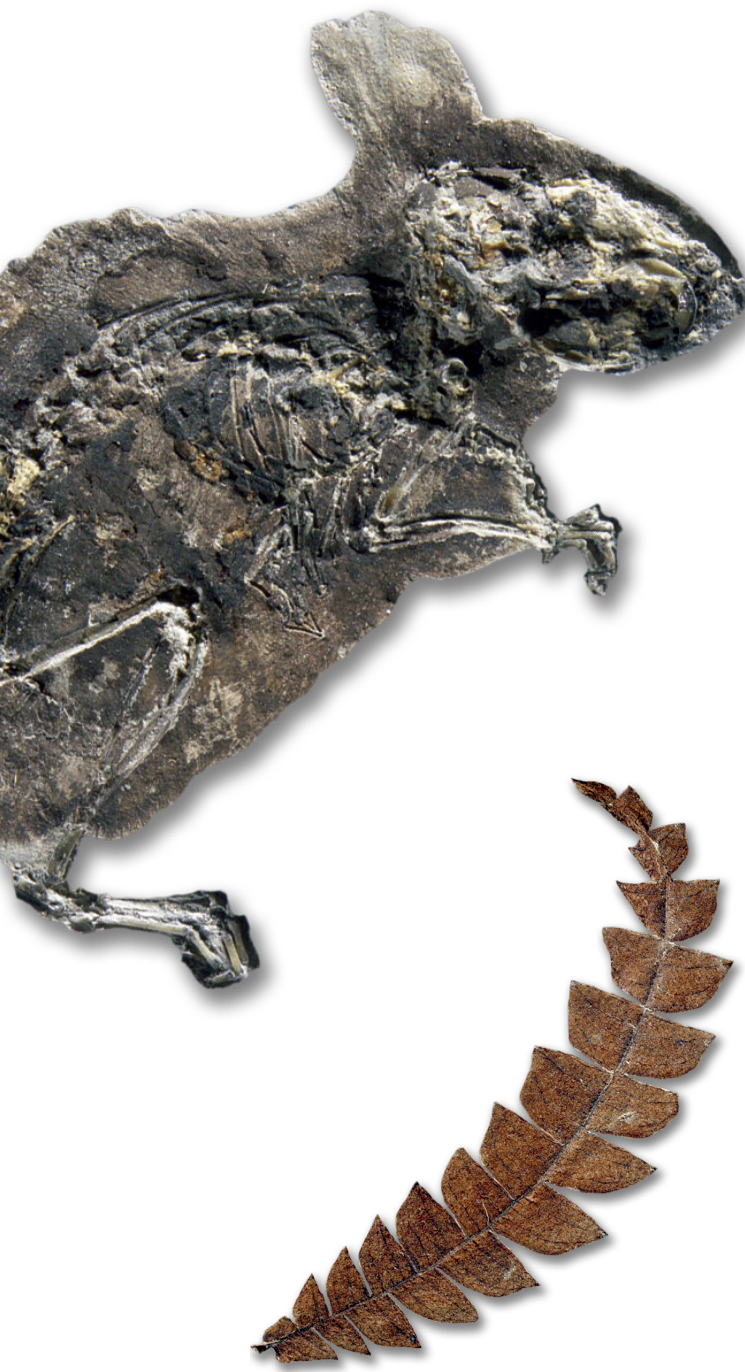

ISBN: 978-3-86395-135-1
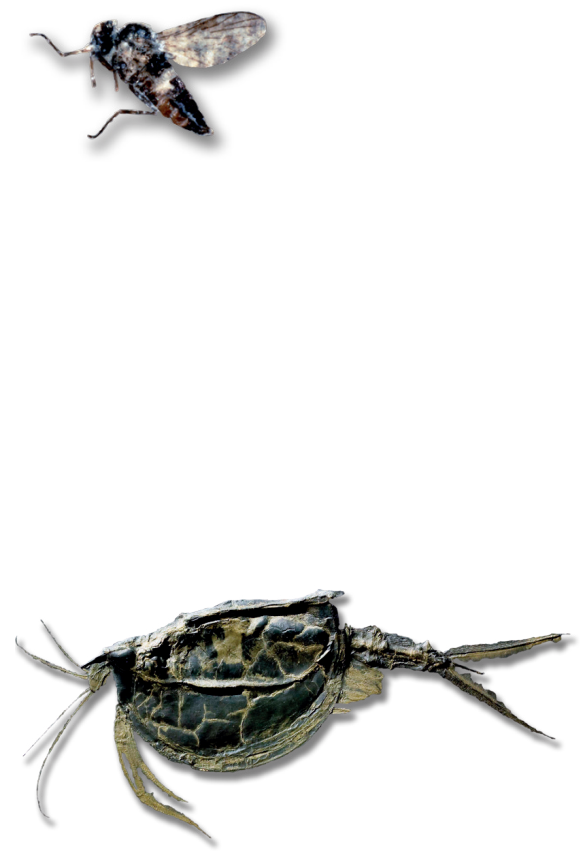

GEORG-AUGUST-UNIVERSITÄT GÖTTINGEN

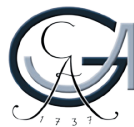

Universitätsdrucke Göttingen 